$$
\text { UNIVERSIDADE DE SÃO PAULO }
$$

FACULDADE DE FILOSOFIA, LETRAS E CIÊNCIAS HUMANAS DEPARTAMENTO DE LETRAS CLÁSSICAS E VERNÁCULAS

PROGRAMA DE LITERATURA BRASILEIRA

\title{
COMIGO E CONTIGO A ESPANHA: UM ESTUDO SOBRE JOÃO CABRAL DE MELO NETO E MURILO MENDES
}

\section{Ricardo Souza de Carvalho}

Tese apresentada ao Programa de Pós-Graduação em Literatura Brasileira, do Departamento de Letras Clássicas e Vernáculas da Faculdade de Filosofia, Letras e Ciências Humanas da Universidade de São Paulo, para obtenção do título de Doutor em Letras.

Orientador: Prof. Dr. João Adolfo Hansen 


\section{AGRADECIMENTOS}

- CAPES, pela concessão da bolsa do Programa de Doutorado no País com Estágio no Exterior, que possibilitou a minha pesquisa na Espanha de setembro de 2004 a maio de 2005;

- Professor Fernando Rodriguez de la Flor, da Universidad de Salamanca, pela atenção e gentileza em supervisionar meu trabalho durante esse período;

- Biblioteca da Facultad de Filología - Universidad de Salamanca;

- Casa Museo Unamuno - Salamanca;

- Fundación Jorge Guillén - Valladolid;

- Biblioteca Pública de Valladolid;

- Biblioteca Nacional - Madri;

- Real Academia Española - Madri;

- Biblioteca de Catalunya - Barcelona;

- Fundació Antonio Tapiès - Barcelona, em especial a Gloria Domenech;

- Fundació Joan Brossa - Barcelona, em especial a Gloria Bordons e Pepa Llopis;

- Fundació Vila Casals - Barcelona;

- Pilar Gomez Bedate, pelas informações e materiais sobre Angel Crespo;

- Maite Santos Torroella, pela agradável tarde em que conversarmos sobre Rafael Santos Torroella, e a persistente busca das fotos de Cabral e Murilo;

- Enric Tormo i Freixa, pela entrevista concedida e por me mostrar o seu mundo da tipografia;

- José Hernández Sanchez, pelas informações e materiais sobre Francisco García Vilella;

- Fundación Rafael Alberti - Puerto de Santa María - Cádiz;

- Os amigos que me deram o apoio e o carinho durante meu "tempo espanhol": Ivani; Enrique; Tina e Frank, a presença alemã na Espanha; e Antonio, da cidade de Zamora, "Duero le cercaba al pie,/ fuerte es a maravilla", como canta o romancero.

No meu "tempo brasileiro":

- Biblioteca do Instituto de Estudos Brasileiros - USP;

- Centro de Estudos Murilo Mendes - Juiz de Fora; 
- Arquivo-Museu de Literatura Brasileira - Fundação Casa de Rui Barbosa, em especial a Julio Castañon Guimarães;

- Professores María Concepción Piñerno Valverde, Augusto Massi, Mario Miguel González e Cilaine Alves Cunha;

- João Adolfo Hansen, pela orientação competente e amiga;

- minha família e amigos, em todos os "tempos", sempre comigo. 


\section{RESUMO}

Murilo Mendes e João Cabral de Melo Neto, em vários momentos de suas trajetórias, mantiveram um diálogo para ressaltar as evidentes diferenças ou para incorporar procedimentos. A Espanha é o ponto central desse intercâmbio, comparecendo tanto como tema, quanto como parâmetro literário e pictórico para as poéticas de ambos. Além disso, estabeleceram contato com importantes escritores e artistas plásticos espanhóis, entre as décadas de 40 e 60. A referência da Espanha configura determinadas especificidades dos dois poetas em relação à poesia brasileira do século XX.

Palavras-chave: João Cabral de Melo Neto - Murilo Mendes - Espanha - poesia brasileira

\section{ABSTRACT}

Murilo Mendes and João Cabral de Melo Neto, in many moments of their carriers, have maintained a dialogue to stand out some differences or to incorporate methods. Spain is the nucleus of this interchange, developing such as theme as literary and pictorial parameter of both poetics. Furthermore, they established contact with important Spanish writers and plastic artist between 1940's and 1960's. The Spanish reference configures unique characteristics in both poets in respect to Brazilian poetry of the $20^{\text {th }}$ century.

Key words: João Cabral de Melo Neto - Murilo Mendes - Spain - Brazilian poetry 


\section{ÍNDICE}

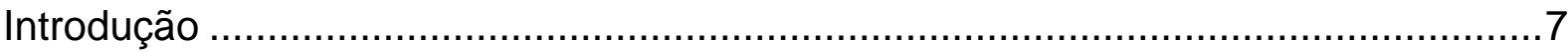

1. A imagem entre Cabral e Murilo ................................................................ 7

2. A Espanha de Cabral .................................................................................. 10

3. A Espanha de Murilo .................................................................................. 14

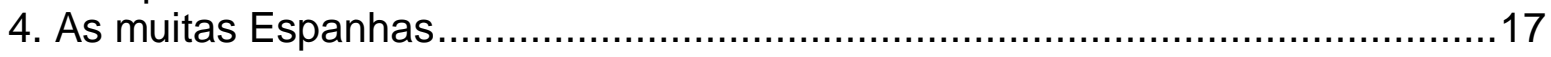

CAPÍTULO 1: Leituras e leitores espanhóis de Cabral ..........................................24

1. Uma epígrafe e dois poemas: Jorge Guillén e Rafael Alberti ............................28

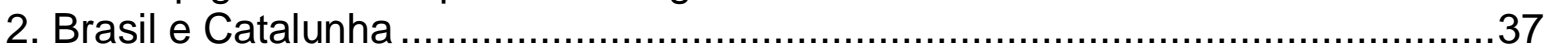

3. O rio e seus afluentes: a poesia medieval espanhola ...................................44

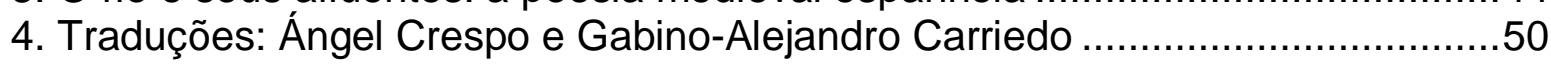

CAPÍTULO 2: Leituras e leitores espanhóis de Murilo ............................................58

1. Entre os "mestres do passado" e do presente..................................................62

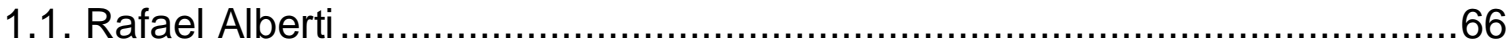

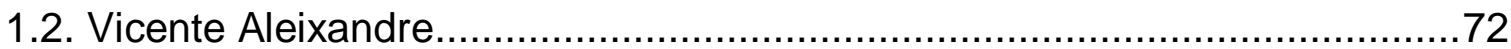

1.3. Dámaso Alonso .............................................................................. 74

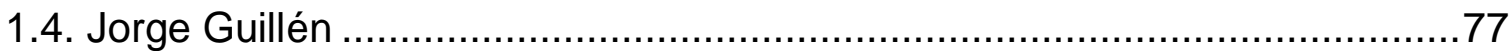

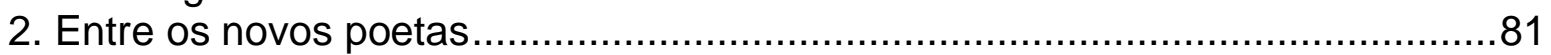

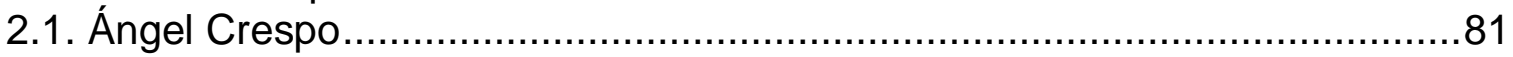

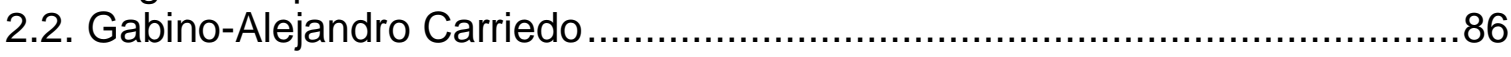

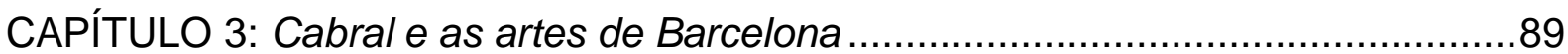

1. O artesão tipógrafo............................................................................ 91

2. O cavalo de todas as cores de Franciso García Vilella .................................97

3. Joan Miró: o "sólido artesão da Catalunha" ............................................... 99

4. Tapiès, Cuixart, Ponç ...................................................................... 112

CAPÍTULO 4: O museu espanhol de Murilo.........................................................117

1. A pintura antiga da Catalunha ............................................................ 121

2. El Greco, o pintor de Toledo.................................................................. 124

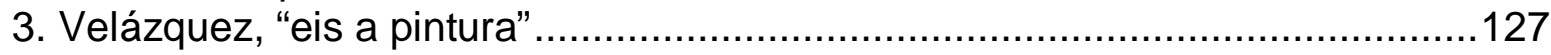

4. O touro e toureiro Goya.......................................................................... 130

5. A desordem e a ordem do século XX: Picasso, Gris e Miró ..............................133

6. Da Espanha ao Brasil: Isabel Pons ..............................................................139

CAPÍTULO 5: Paisagens e figuras da Espanha de Cabral ...................................142

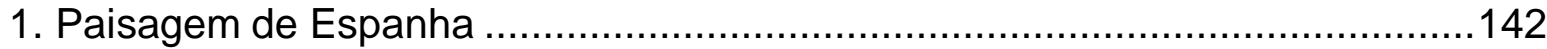

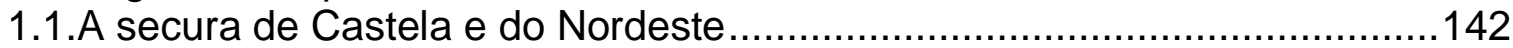

1.2. Andaluzia e "ainda, ou sempre, Sevilha" ................................................... 153

2. O gosto pelos extremos: a tauromaquia e o flamenco ................................163

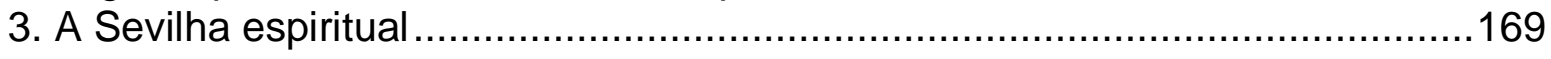

CAPÍTULO 6: Os tempos da Espanha de Murilo ...............................................178

1. O começo e o fim da Espanha ......................................................... 184

2. O núcleo de Espanha: Castela e o Siglo de Oro .........................................186

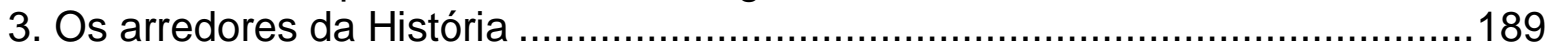

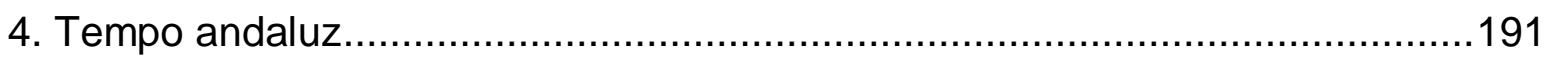


5. Tempo de hoje e de sempre na Catalunha ................................................193

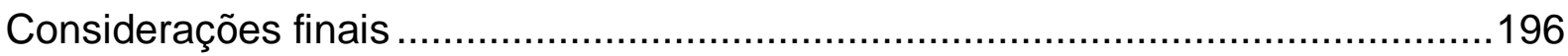

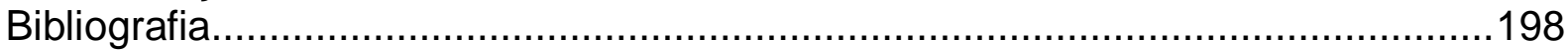

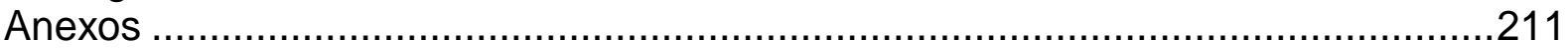

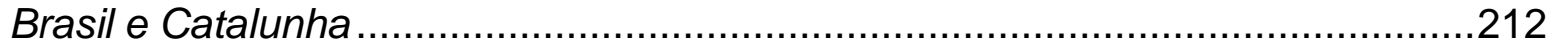

Quinze poetas catalães .....................................................................214

Traduções de Joan Brossa ao catalão de três poemas d'O engenheiro................231

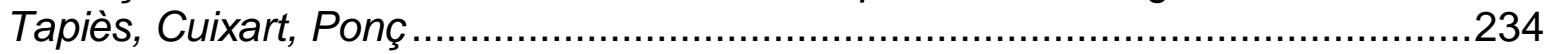

Xilografia popular na Catalunha ...............................................................23

Entrevista com Enric Tormo ...................................................................240

Prólogo a En va fer Joan Brossa.................................................................243

Murilo Mendes e João Cabral de Melo Neto …….......................................246

Epígrafes da $1^{a}$ edição de Tempo espanhol (1959) ........................................248

Nota preliminar a "Poemas de Murilo Mendes"..................................................249

Enquete sobre a literatura brasileira de vanguarda.......................................251

Nota aos Poemas inéditos de Murilo Mendes ..............................................252

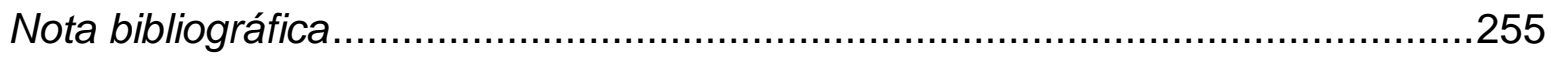

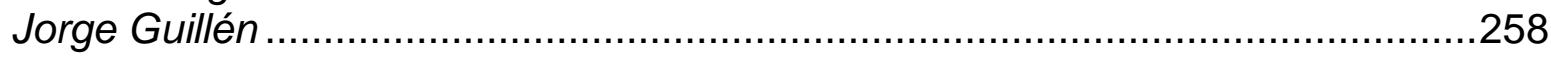

Correspondência de Cabral e Murilo com escritores espanhóis .........................261

Dedicatórias autógrafas em livros .......................................................................26

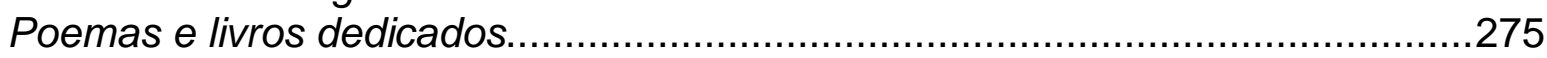

Traduções da obra de João Cabral de Melo Neto na Espanha............................278

Traduções da obra de Murilo Mendes na Espanha.........................................28

Artistas plásticos espanhóis no acervo de Murilo Mendes .................................281

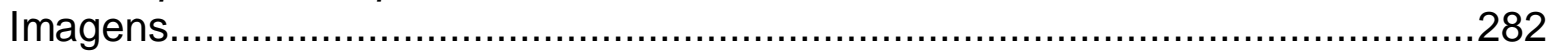




\section{Introdução}

\section{A imagem entre Cabral e Murilo}

O primeiro encontro entre João Cabral de Melo Neto e Murilo Mendes ocorreu em 1940, no Rio de Janeiro. Enquanto Cabral divulgava seus primeiros poemas na revista Renovação de Recife, Murilo era o autor maduro de seis obras publicadas desde 1930, o que não impediu que recebesse generosamente o "poeta novo", dedicando-Ihe um pequeno artigo no periódico carioca Dom Casmurro de 2 de março daquele ano: "E hoje aparece-nos, vindo pelo último navio de Recife, o poeta de vinte anos João Cabral de Melo Neto. (...) No plano propriamente literário, as influências que ele mais acusa são as de Bandeira e Drummond, portanto está acertando o caminho."1 Talvez por modéstia ou falta de percepção, deixou de citar a si mesmo; mas Cabral explicitou mais de uma vez a presença marcante de Murilo em sua obra inicial.

O intermediário do primeiro contato entre Cabral e Murilo foi o escritor Willy Lewin. Por volta de 1938, em Recife, Cabral freqüentava o Café Lafayette, ponto de encontro de intelectuais reunidos ao redor de Lewin e do pintor Vicente do Rego Monteiro. Lewin, em suas viagens ao Rio de Janeiro, travou amizade com Murilo², compartilhando um grande interesse pelo surrealismo, mais pela pintura do que pela escrita automática proclamada por André Breton no Manifesto de 1924. Esse entusiasmo "visual" deixa-se entrever no curioso registro de Lewin sobre um passeio ao lado de Murilo pelas ruas da Capital Federal: "(Rio, 1937) M. M e eu descobrimos, por acaso, uma vitrine de utensílios cirúrgicos, manequins anatômicos, instrumentos ortopédicos. Estamos 'bouleversés'. Ali estavam, vivos, eloqüentes, Chirico, Dali, os surrealistes."3 Em 1936, Lewin, nos seus Quinze

\footnotetext{
${ }^{1}$ GUIMARÃES, Julio Castañon, org. Murilo Mendes: 1901-2001. Juiz de Fora, CEMM/ UFJF, 2001, p. 57.

${ }_{2}^{2}$ Lewin freqüentou com Murilo o grupo de artistas e intelectuais da boemia carioca: “(...), companheiro de mesa de bar de 1929, quando estivemos várias vezes juntos, você, o pintor Cícero Dias, o arquiteto Carlos Leão e eu, poeta sem versos,(...)" (LEWIN, Willy. Saudação a Murilo Mendes. Boletim de Ariel. a. 3, n. 12, Rio de Janeiro, set. 1934, p. 321).

${ }^{3}$ LEWIN, Willy. De um diário de poesia. Renovação. a. 2, n. 5, Recife, ago. 1940, p.10.
} 
poemas, tentara recuperar a atmosfera de alguns quadros, como em "Chirico ou o fim do mundo":

Colóquio das estátuas impassíveis

na praça deserta

onde sopra um vento de peste

e um anjo lívido

agita as grandes asas.

Perspectivas oníricas

sob uma luz de eclipse. ${ }^{4}$

Murilo reconhecera o valor dos Quinze poemas, indicando o que ele próprio buscava em sua poesia: "esquemáticos, concentrados, incorporam-se à corrente espiritualista que aumenta dia a dia, sendo alguns notáveis pelo seu mistério e capacidade de sugestão". 5 O "mistério" e a "capacidade de sugestão" conformam as diretrizes do surrealismo concebido por Lewin, segundo as notas "De um diário de poesia": "O que existe de belo numa paisagem, nas coisas do mundo, é a eterna, a misteriosa, a invisível Presença que elas ocultam e refletem. Um poeta realmente materialista: que absurdo." ; "O poeta 'dorme'. Ou respira numa noite profunda. Acordando, em plena luz, entre os homens, o poeta é um destroço lamentável, um peixe atirado à praia."7; "A densidade do mistério e não a clareza do racional é que é a linguagem da poesia." Essas idéias repercutiram, de certa maneira, no jovem Cabral, que, em sua tese no Congresso de Poesia do Recife, "Considerações sobre o poeta dormindo", em 1941, apresentava como epígrafe o poema "Sono", de Lewin. Embora tenha começado a escrever poemas marcado por esse contexto, encaminhou-se justamente pela trajetória negada por Lewin, a do poeta "materialista", "em vigília" e da "clareza do racional".

Ao lado do surrealismo, o catolicismo também ocupava as preocupações comuns a Murilo e Lewin. Quando da publicação de Tempo e eternidade, em 1935,

\footnotetext{
${ }^{4}$ Quinze Poemas. Recife, 1936. Não há indicação de número de página.

${ }^{5}$ MENDES, Murilo. "Poesia universal". Boletim de Ariel. a. 7, n. 8, Rio de Janeiro, maio 1937, p. 220221. Na biblioteca do poeta, consta um exemplar de Quinze poemas com dedicatória: "Para Murilo Mendes, afetuosamente Willy Lewin Recife, Natal. 1936".

${ }_{7}^{6}$ Renovação. a. 2, n. 5, Recife, ago. 1940, p. 10.

${ }^{7}$ Idem, ibidem.

${ }^{8}$ Renovação. a. 2, n. 2, Recife, março 1940, p. 22.
} 
Lewin acolheu Murilo como seu "irmão em Jesus Cristo". 9 Já Cabral afastava-se dessa postura, reconhecendo divergências com Lewin:

(...) Eu me lembro de uma conferência que ele fez no Círculo Católico de Pernambuco, onde ele comparava dois grandes poetas franceses da geração dele, que foram Claudel e Valéry, e ele dizia que, apesar dos dois serem grandes poetas, faltava uma certa dimensão a Valéry, que era exatamente esse catolicismo, esse espiritualismo. Eu era o contrário, eu me sentia inteiramente atraído por Valéry, sempre fui incapaz de transcendência. ${ }^{10}$

Se por um lado Cabral não se identificava com a "transcendência" da poesia de Murilo, por outro, valorizou nela o lugar central ocupado pela imagem:

Há um certo parentesco entre Pedra do sono e certa poesia entre nós, a do sr. Murilo Mendes, por exemplo para quem a imagem não é um equivalente simbólico de uma realidade observada, mas um valor em si. Quando um poeta escreve "A mulher do fim do mundo/ dá de beber às estátuas", creio que não é a um determinado conceito que ele (o sr. Murilo Mendes, no caso) está vestindo de uma aparência poética (conceito que o leitor deveria procurar no avesso da página), mas o simples fato de que sua inteligência (seu dom poético, como quiserem) criou, imaginando aquele comportamento ou aquela relação, um fato poético. Pedra do sono é um livro cujo ponto de partida foi um tratamento da imagem como tal. ${ }^{11}$

Os versos citados pertencem ao poema "Metade pássaro"12, da coletânea $O$ visionário, escrita entre 1930 e 1933, mas apenas publicada em 1941, quando se dedicava a Pedra do sono. Mais de uma imagem desse livro de Murilo ecoa na obra de estréia de Cabral: os anjos murilianos de "Evocação da morta" ("Eu vi três anjos distintos/ Rodando num carrossel.") irmanam-se nas diversões prosaicas com os de "A poesia andando" ("estendem-se avenidas iluminadas/ que arcanjos

\footnotetext{
${ }^{9}$ Saudação a Murilo Mendes. Op. cit., p. 321.

${ }^{10}$ Entrevista de 1990 (ATHAYDE, Félix de, org. Idéias fixas de João Cabral de Melo Neto. Rio de Janeiro: Nova Fronteira: FBN; Mogi das Cruzes, SP: Universidade de Mogi das Cruzes, 1998, p. 87).

${ }_{11}^{11}$ Entrevista de 1946 (Idem, ibidem, p. 99).

${ }^{12}$ No livro publicado, a belíssima $1^{\mathrm{a}}$ estrofe é a seguinte: "A mulher do fim do mundo/ Dá de comer às roseiras, / Dá de beber às estátuas,/ Dá de sonhar aos poetas." (Poesia completa e prosa. Edição de Luciana Stegagno Picchio. Rio de Janeiro: Editora Nova Aguilar, 1995, 223-224. A partir daqui essa edição passa a ser referida como PCP).
} 
silenciosos/ percorrem de patins"). Benedito Nunes reconheceu o verso "O poema obscuro dorme na pedra", de As metamorfoses (1941), como possível "divisa à primeira experiência poética de João Cabral: captar a poesia latente ao espírito em estado de sono."13

Cabral confessou que sua dívida com a poesia de Murilo em relação à imagem, apesar das evidentes diferenças, marcou toda a sua obra posterior:

(...) Creio que nenhum poeta brasileiro foi mais diferente de mim: desde a visão da vida (e, por parte dele, de uma sobrevida), até a visão da poesia, como função e organização. Pois bem: creio que nenhum poeta brasileiro me ensinou como ele a importância do visual sobre o conceitual, do plástico sobre o musical (a poesia dele, que tanto parecia gostar de música, é muito mais de pintor ou cineasta do que de músico). Sua poesia me ensinou que a palavra concreta, porque sensorial, é sempre mais poética do que a palavra abstrata, e que assim, a função do poeta é dar a ver (a cheirar, a tocar, a provar, de certa forma a ouvir: enfim, a sentir) o que ele quer dizer, isto é, dar a pensar. O fato de Murilo ter usado essa concepção da palavra poética com uma intenção completamente oposta à minha, não diminui em nada a influência que ele exerceu sobre mim. Influência básica, porque se situa na própria concepção do tratamento da poesia poética. ${ }^{14}$

\section{A Espanha de Cabral}

Desde o início de sua obra, Cabral procurou um caminho próprio, não se submetendo totalmente às referências seja dos poetas do Recife a Lewin, da Geração de 45 ou dos mestres do modernismo, Drummond e Murilo. Faltava-lhe um panorama diferente que viesse ao encontro de suas inquietações. A entrada na carreira diplomática definiu os rumos da sua trajetória poética. Entre vários países, a Espanha foi onde mais tempo permaneceu, durante quatro estadas. Os mais de dez anos vividos nesse país, com alguns intervalos, possibilitaram o amadurecimento do

\footnotetext{
${ }^{13}$ NUNES, Benedito. João Cabral de Melo Neto. $2^{\text {a }}$ ed. Petrópolis: Vozes, 1974, p. 36. Também reconhecia a "nuvem" como outra imagem recorrente tanto em Pedra do sono quanto na poesia muriliana, principalmente no seu período entre 1935 e 1945 (p. 39).

${ }_{14}$ Entrevista de 1976 (MAMEDE, Zila. Civil geometria: bibliografia crítica, analítica e anotada de João Cabral de Melo Neto, 1942-1982. São Paulo: Nobel/ Edusp/ INL/ Vitae/ Governo do Estado Rio Grande do Norte, 1987, p. 155).
} 
poeta, quando escreveu e publicou a parte crucial de sua obra, de Psicologia da composição (1947) a A educação pela pedra (1966).

Cabral deixou pela primeira vez o país para trabalhar como cônsul-geral em Barcelona, entre 1947 e 1950. Logo se encantou com a cultura espanhola, acompanhando, por exemplo, as touradas. Das arenas aos livros, reconheceu uma longa tradição literária, pois antes pautara-se pelas correntes modernas da poesia francesa, Mallarmé e Valery, e da poesia brasileira, Drummond e Murilo. Em carta de 4 de setembro de 1947 a Manuel Bandeira, comenta a intensa leitura que vinha fazendo da poesia espanhola, das origens aos contemporâneos:

De Barcelona não preciso Ihe dizer muito; está na Espanha e a Espanha de hoje é aquele seu estribilho, lembra-se? Eu o tenho sempre na cabeça e permanentemente estou examinando o que há de sim e de não nas coisas que vou encontrando. O que vale é que a percentagem de sins é bem grande. Há uma "Espanha-sim" realmente indestrutível. Nessa estou mergulhado desde que cheguei: Mio Cid, Fernán González, Berceo, Arcipreste de Hita, Góngora, Góngora, Góngora, etc. É claro que os poetas primeiro, como é claro também que a exploração não é tão cronologicamente sistemática como enumerei. Mas o é tanto quanto possível, isto é, quando o interesse pelos modernos me permite sistema. ${ }^{15}$

No entanto, o ambiente não era dos mais alentadores: dois anos apenas do fim da Segunda Guerra Mundial e da condenação pela ONU da ditadura de Franco, a Espanha atravessava tempos de crise econômica e ferrenha censura. Cabral, na condição de diplomata, teve a oportunidade de conhecer desde o já consagrado Joan Miró, mas não bem visto pelo regime, até os jovens artistas que iniciavam um estimulante processo de renovação. Trata-se sem dúvida do período mais fértil que experimentou na Espanha, em que não apenas recebeu contribuições, mas pôde inclusive atuar de forma construtiva na obra de alguns dos nomes mais importantes da arte espanhola do século XX.

Mais concretamente, havia a imposição do castelhano frente ao catalão, idioma nativo dessa parte do país. Para esses artistas, escrever em catalão era uma forma de resistência, luta que repercutiu em Cabral, que chegou a estudar e traduzir

\footnotetext{
${ }^{15}$ SÜSSEKIND, Flora, org. Correspondência de Cabral com Bandeira e Drummond. Rio de Janeiro: Nova Fronteira, Edições Casa de Rui Barbosa, 2001, p. 32.
} 
poesia do catalão ao português, caso pioneiro e praticamente até hoje raro entre nós:

Entrei em contacto, aqui, com um grupo de jovens escritores catalães que publicam duas revistas. Clandestinas, esclareço, porque o catalão, desde 1939, é perseguido aqui. A princípio não podiam nem falar; a partir do desembarque dos americanos na África, passaram a tolerar a língua oral; a partir de 1945, fim da guerra, passaram a permitir os livros em catalão, se em pequenas tiragens fora do comércio; e, finalmente, de um ano para cá, permitem os livros - com restrições mas não as revistas e os jornais. Como eu ia dizendo, acima, conheço esses jovens catalães, ávidos de intercâmbio e de que se conheça, fora da península, sua "cultura ameaçada". ${ }^{16}$

Os jovens mencionados eram o poeta Joan Brossa, o escritor Arnau Puig e os pintores Antonio Tapies, Modesto Cuixart, Joan Ponç e Josep Tharrats. A primeira revista, Algol, com um único número, publicou-se no final de 1946. Depois, aquela que levava o nome do grupo, Dau al set, circulou de setembro de 1948 a dezembro de 1956. Cabral simplesmente tornou-se coadjuvante, fundamental digase de passagem, de um dos grupos de vanguarda mais importantes da Espanha do pós-guerra. Embasado pelo marxismo, passou a discutir com eles a importância da questão social em suas obras, para não se limitarem à preocupação formal ou estética. Em nota à publicação em 1979 de $U$ no ès ningú, realizada em 1950, Brossa e Tapies enfatizam a participação do brasileiro em suas trajetórias artísticas: "Em 1950, os comunistas catalães estavam presentes no propósito de remarcar a dimensão política de nossas obras sem abandonar o caminho da renovação. Nesse ponto, e na perspectiva daqueles anos, também estão em dívida com o poeta e diplomata João Cabral de Melo, que residia em Barcelona."17

Além disso, durante todo esse período, sob o selo O Libro Inconsútil, imprimiu exemplares de poetas brasileiros e espanhóis, fora suas próprias obras Psicologia da composição com a Fábula de Anfion e Antiode (1947) e O cão sem plumas (1950), os quais presenteava os amigos na Espanha e no Brasil. ${ }^{18}$ Ainda

\footnotetext{
${ }^{16}$ Carta a Manuel Bandeira de 20 de julho de 1948 (Idem, ibem, p. 89).

${ }^{17}$ BROSSA, Joan. Ball de sang (1941-1954). Barcelona: Editorial Crítica, 1982, p. 117.

${ }^{18}$ Os livros impressos foram os seguintes: Mafuá do Malungo (1948), de Manuel Bandeira, Pequena antologia pernambucana (1948), de Joaquim Cardozo; Corazón en la tierra (1948), de Alfonso Pintó;
} 
como editor, idealizou com o poeta português Antonio Serpa a revista $O$ cavalo de todas as cores, que apenas teve o primeiro número em janeiro de 1950, com poesia de Vinícius de Moraes, Rafael Santos Torroella e José Regio.

As repercussões mais diretas dessa intensa estada espanhola na obra cabralina somente surgiriam em 1954, com O rio, no qual incorpora formas e imagens da poesia medieval espanhola, e Paisagens com figuras, no qual apresenta a temática espanhola recorrente em sua obra.

Em 1956, Cabral retornou à Espanha como cônsul-adjunto em Barcelona, mas o encarregaram de pesquisar os documentos relativos ao Brasil no Arquivo das Indias de Sevilha. O Ministério de Relações Exteriores publicou o resultado de seu trabalho apenas em 1966, O arquivo das Indias e o Brasil. Documentos para a História do Brasil existentes no Arquivo das Indias de Sevilha, inventário de 6 mil documentos de 1483 a 1830, "o maior realizado por brasileiro em arquivo de Espanha", segundo as palavras do préfacio do historiador José Honório Rodrigues. Em carta de 6 de fevereiro de 1957 ao casal Clarice Lispector e Maury Gurgel, aponta as conveniências desse trabalho: "Minha vida em Sevilha tem vantagens. Como Vcs. sabem (saberão) o Ministério me mandou para cá fazer investigações no Arquivo das Indias. A posição é boa, me deixa livre, sem chefes, sem caceteações de Consulado, etc. E sobretudo me deixa em Sevilha."19 A partir desse momento incluiu a cidade andaluza à sua geografia poética, em Quaderna (1961), na qual figuram duas peças fundamentais ligadas ao flamenco: "Estudos para uma bailadora andaluza" e "A palo seco". Se não chegou a escrever um livro inteiramente dedicado à Espanha, a última obra publicada, Sevilha andando (1990) traz a cidade que melhor expressa sua relação com esse país.

O terceiro "tempo espanhol" de Cabral foi entre 1960 e 1961 como primeiro secretário da Embaixada do Brasil em Madri. Incentivou ao poeta Ángel Crespo a criação da Revista de Cultura Brasileña, que começou a ser publicada em 1962

Acontecimento do soneto (1948), de Ledo Ivo; Alma a la luna (1948), de Juan Ruiz Calonja; Sonets de Caruixa (1949), de Joan Brossa; El poeta conmemorativo, de Juan Eduardo Cirlot; Pátria minha, de Vinicius de Moraes; e a Antología de poetas brasileños de ahora, com seleção e tradução de Alfonso Pintó de poemas de Murilo Mendes, Cecília Meireles, Carlos Drummond de Andrade, Augusto Frederico Schmidt e Vinicius de Moraes.

${ }_{19}$ SOUSA, Carlos Mendes. Cartas de João Cabral de Melo Neto para Clarice Lispector. Colóquio/ Letras. Paisagem tipográfica. Homenagem a João Cabral de Melo Neto (1920-1999). n. 157/158, Lisboa, jul-dez. 2000, p. 297. Sobre a pesquisa de Cabral no Arquivo das Indias, consutar a correspondência com José Honório Rodrigues, entre 1957 e 1959 (RODRIGUES, Lêda Boechat, org. Correspondência de José Honório Rodrigues. Rio de Janeiro: Academia Brasileira de Letras, 2000). 
pela Embaixada brasileira. O periódico, ao veicular principalmente traduções ao espanhol e ensaios a respeito da poesia brasileira de diversas épocas e tendências - com ênfase na produção contemporânea - constituiu-se em um importante meio para as relações literárias entre Brasil e Espanha.

Cabral permaneceu ainda como cônsul-geral em Sevilha entre 1962 e 1964, e em Barcelona entre 1967 e 1969, durante os quais voltou-se mais à sua obra do que às intervenções.

\section{A Espanha de Murilo}

Ao que tudo indica, Murilo já possuía uma íntima relação com a Espanha muito antes de conhecê-la. Dizia que um remoto antepassado seu carregava o sobrenome Medinaceli, hipotético local de nascimento do autor anônimo do Poema de Mio Cid. Em 1920 assinava a coluna "Chronica mundana" do jornal A Tarde de Juiz de Fora com o pseudônimo "De Medinacelli". ${ }^{20}$ Mais tarde, Manuel Bandeira, no poema "Saudação a Murilo Mendes", acabou incorporando o ilustre desconhecido sobrenome: "Murilo Medina Celi Monteiro Mendes". Sua possível ascendência espanhola não deixou apenas um sobrenome, mas também certa "herança espiritual", como registrou em "Mapa" do livro de estréia Poemas (1930): "Estou com meus antepassados, me balanço em arenas espanholas,/ é por isso que saio às vezes pra rua combatendo personagens imaginários." (PCP, 116)

Além dos antepassados, a presença do país ibérico já lhe despertava a atenção desde a infância por intermédio da Prima Vera, "afetuosa parenta de quem me recordo por ter sido a única pessoa do tempo juiz-forano a mencionar a Espanha onde outrora viajara, trazendo-me ecos de palavras quase contemporâneas da formação do meu mundo: sapateado castanholas tourada zarzuela, a última me intrigando particularmente no meio das minhas já insônias." 21

Apesar da formação francesa predominante, Murilo teria estudado o espanhol, algo extravagante para um intelectual brasileiro da década de 20: "Dei-me ao luxo até de, aos vinte anos, tomar um professor de espanhol.(...) Estudei o

\footnotetext{
${ }^{20}$ V. SILVA, Teresinha V. Zimbrão, org. Chronicas mundanas e outras crônicas: as crônicas de Murilo Mendes. Juiz de Fora: UFJF, 2004, p. 143-163.

${ }^{21}$ Espaço espanhol (PCP, 1187).
} 
espanhol por minha conta, porque tinha uma atração enorme pela Espanha e tinha lido o livro de Maurice Barrès sobre El Greco, aos 17 anos."22 Os amigos começavam a perceber essa fascinação: Ismael Nery, no quadro $A$ espanhola (1923), representa uma moça com mantilha e expressão austera, e ao fundo, à direita, a cabeça de Murilo.

Ao longo da obra, deixou alguns rastros da Espanha. Em um clima lúdico, chegou a reconhecer, em "Prefácio de Pinzón" de História do Brasil (1933), o descobrimento pelos espanhóis: "Quem descobriu a fazenda/ Por Sant Tiago, fomos nós" (PCP, 143). Na coletânea Mundo enigma (1945), "A Desejada" revela uma figura feminina sob uma ótica espanhola, ou melhor, "dualista", mesclando sensualidade e devoção:

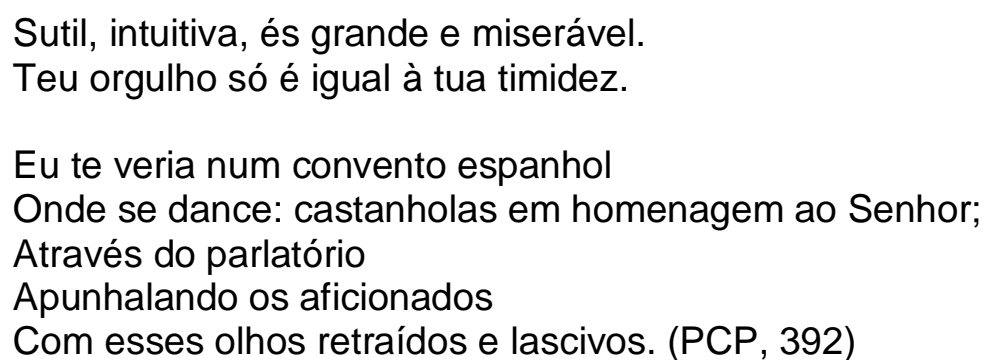

No Rio de Janeiro conheceu José Bergamín, o "ensaísta-polemista" da Geração de 27, antes de seguir para seu exílio no México, de onde lhe enviou em 1941 exemplares dedicados de Disparadero español (1940) e El pozo de angusia (1941). ${ }^{23}$ Idenficou-se com a sua "luta pela renovação do catolicismo, figura postconciliar já antes do Concílio". ${ }^{24}$

Compartilhou a admiração por Lorca com outros artistas e intelectuais brasileiros ao participar do conselho consultivo do Ateneu García Lorca. Quando da inauguração em julho de 1946, homenageou o poeta assassinado dez anos antes: "vida que viva volveu/ contigo a morte não pode,/ nervo, entusiasmo, fervor.../ García Lorca tu és". 25

Entre 1952 e 1956, teve sua primeira estada na Europa em missão cultural pelo Ministério de Relações Exteriores. Em carta de Lisboa, em 3 de fevereiro de

\footnotetext{
${ }^{22}$ ARAÚJO, Laís Corrêa de. Murilo Mendes: ensaio crítico, antologia, correspondência. São Paulo: Perspectiva, 2000, p. 356.

${ }^{23} \mathrm{~V}$. Anexos, Dedicatórias autógrafas em livros.

${ }^{24}$ Espaço espanhol (PCP, 1170).

${ }^{25}$ ANTELO, Raúl. Literatura em revista. São Paulo: Ática, 1984, p. 290-291.
} 
1953, declara a Edson Nery da Fonseca a importância da experiência para sua trajetória artística:

Estamos viajando pela Europa há quase 5 meses. Como v. poderá avaliar, tem sido uma experiência fecunda para mim. Além de inúmeras cidades de artes, museus, galerias antigas, modernas, igrejas, "ateliers", etc., estabeleci contatos com personalidades altamente interessantes. Fui até à Holanda, completando assim o conhecimento da cultura européia, iniciado na Espanha e Itália.

Aconselho-o vivamente a economizar e fazer uma viagem assim, logo que possa. A gente nasce, é claro, sabendo que a Europa é uma grande Consort, mas o que não se pode avaliar bem é o rendimento espiritual que uma tal viagem poderá nos proporcionar. ${ }^{26}$

Em Barcelona, conheceu Rafael Santos Torroella e Alfonso Pintó, ambos tradutores de poemas seus ${ }^{27}$, e em Madri, o escritor José Antonio Novais. Nesse momento, teria descoberto o sentido da História na cidade espanhola de Toledo ${ }^{28}$, onde se cruzaram três civilizações: "Propõe-nos Toledo um encontro de culturas díspares - a cristã, a judia, a mourisca - bem como a superposição de camadas do tempo." ${ }^{29}$ Prosseguiu a revelação no Brasil, ao escrever Contemplação de Ouro Preto (1954), a primeira de sua obra a se centrar em um determinado espaço, repleto de história e tradições. A Espanha, em sua dimensão católica, é aludida nos versos de "Procissão do enterro em Ouro Preto": "Ergue um Cristo na cruz todo em chagas aberto,/ Deus barroco espanhol, com enorme resplendor." (PCP, 472).

Em 1956, teve seu visto negado para ingressar na Espanha como professor devido à sua clara oposição à ditadura de Franco. No ano seguinte, mudou-se para a Itália para exercer o cargo de professor de Literatura Brasileira na Universidade de Roma. Porém, passava as férias quase todos os anos em Portugal, terra natal de sua esposa, Maria da Saudade Cortesão, e na Espanha: "Minha aversão ao regime franquista é menor do que o meu amor à Espanha, por isso visito-a sempre que

\footnotetext{
${ }^{26}$ FONSECA, Edson Nery da, org. Cartas a Edson Nery da Fonseca. Recife: Companhia Pacífica, 1995, p. 26-27.

${ }^{27} \mathrm{~V}$. Anexos, Traduções de poemas de Murilo Mendes na Espanha.

28 Apud MOURA, Murilo Marcondes de. Murilo Mendes: A Poesia como Totalidade. São Paulo: EDUSP: Giordano, 1995, p. 175.

${ }^{29}$ Espaço espanhol (PCP, 1135).
} 
posso." (PCP, 1223). Enquanto em Roma encontrava os exilados Rafael Alberti e Jorge Guillén, em Madri reunia-se a Ángel Crespo, Gabino-Alejandro Carriedo, Dámaso Alonso e Vicente Aleixandre, entre outros, relações documentadas tanto nas dedicatórias aos livros, quanto na correspondência mantida do final da década de 50 a meados da de 70 .

Murilo publicou em Lisboa em 1959 o livro de poemas Tempo espanhol, no qual percorre os nomes mais representativos da literatura e pintura espanholas, das origens ao século XX, e as cidades e regiões do país, de Santiago de Compostela a Granada. Ainda entre 1966 e 1969, escreveu o livro de viagens Espaço espanhol, que permaneceu inédito até a edição da Poesia completa e prosa (1994) organizada por Luciana Stegagno Picchio.

Seguindo a experiência dileta de aproximação dos contrários, Murilo encontrou na literatura e na cultura espanholas um território propício a sua poesia:

Muitas vezes tenho me perguntado com qual país me sinto mais afim. Há alguns candidatos. Em grande parte sou de cultura francesa, mas, paralelamente, a Espanha é um país muito apropriado para um poeta. Ortega y Gasset escreveu que na Espanha a anormalidade é a norma. Ángel Ganivet escreveu que a lei da Espanha é o absurdo, sem o absurdo não se pode compreender a Espanha e seus contrastes magníficos. O toureiro, por exemplo, antes de tourear reza ajoelhado e com fé intensa. Talvez se deva a que em grande parte os árabes estiveram plantados oito séculos lá, com uma influência profunda. A Espanha me atrai porque eu gosto de tudo, menos da monotonia. Já disse uma vez a João Cabral de Mello Neto: a Itália é um país traduzido, a Espanha é um país por traduzir... ${ }^{30}$

\section{As muitas Espanhas}

Cabral e Murilo encontraram-se mais de uma vez na Espanha, nova identidade em comum a dois poetas tão diferentes. Enquanto grande parte dos seus compatriotas limitaram-se a homenagear Lorca motivados por seu assassinato ou mais alguns outros nomes, eles tornaram-se singulares na literatura brasileira tanto pela incorporação de temas e formas, quanto pelos contatos com

\footnotetext{
${ }^{30}$ Entrevista de 1972 (GUIMARÃES, Julio Castañon, org. Op. cit., p. 122).
} 
escritores e artistas do país ibérico. Por outro lado, é importante assinalar os momentos em que ambos se voltaram à Espanha em suas obras. Cabral, em 1947, ainda era um poeta em formação, à procura de um caminho; já Murilo, na década de 50, era um poeta maduro, tendo publicado a maior parte de sua produção poética. Para Cabral, a Espanha configura o seu projeto de poesia; para Murilo, a Espanha se conforma ao seu projeto de poesia.

Instigado pela leitura de Tempo espanhol, Cabral endereçou uma carta ao amigo em 22 de janeiro de 1959, comparando o tema da Espanha na obra de ambos:

Quanto à Espanha do livro: devo dizer que a sua deixa a minha humilhada. V. tem sobre este servidor (como dizem os espanhóis) duas vantagens para falar da Espanha: uma é o tom de veemência explosiva que é o próprio dos espanhóis (enquanto a minha veemência é uma veemência incisiva, pouco espanhola, ou quando não, menos espanhola do que a sua); a segunda vantagem é o seu catolicismo. Não digo que todo o católico possa ter a visão total da Espanha que V. tem. Há católicos - a grande maioria - que terá uma visão parcial, forçosamente porque só verão a Espanha negra, se desinteressando pela outra. No meu caso ocorre o contrário: só sou capaz de me interessar pela Espanha realista, a Espanha materialista, a Espanha das coisas. E quando uma manifestação, digamos assim, desse lado "espiritual" da Espanha que V. capta tão bem me interessa, repare que sempre o trato amesquinhando. Exemplo: as corridas de touro, coisa inadmissível a um Espanha-branca como eu: eu as diminuo às dimensões de uma lição de estética; o cante flamenco, idem. Etc. Etc. Quero dizer: sua posição intelectual é muito mais ampla e abarca as Espanhas branca e negra. Você não está dividido e pode exaltar tudo o que interessa à sua sensibilidade. Ao passo que eu, incapaz de me fechar, enquanto sensibilidade, às sugestões da Espanha espiritual, medieval, enfim, ao que um inglês atual chamaria o lado gótico da Espanha, sinto incapacidade em falar delas, incapacidade que entra, como ingrediente fortíssimo, minha aceitação racional dessas coisas. Assim, sua Espanha é muito mais total, completa, do que a minha. A Espanha do Caudillo só vê a Águia dos Áustrias; eu só vejo o galo de Morón de la Frontera (sin plumas y carareando). Ao passo que V. vê e trata dos dois. ${ }^{31}$

\footnotetext{
${ }^{31}$ ARAUJO, Lais Corrêa de. Op. cit., p. 375
} 
Cabral não apenas aponta as diferenças entre os dois tratamentos da Espanha, como também oferece as principais categorias com que a fortura crítica tem abordado os dois poetas. De um lado, o poeta "realista", "materialista", "das coisas"; de outro, o poeta da "totalidade". A separá-los, o catolicismo professo por Murilo desde a década de 30. Embora tal perspectiva seja válida como ponto de partida para uma comparação da presença da Espanha na obra de Cabral e Murilo, merece ser aprofundada para que se possa chegar a uma melhor compreensão de duas trajetórias fundamentais da poesia brasileira do século $X X$.

Murilo também não fugiu ao cotejo com Cabral. Ao escrever em 1964 o "Murilograma a João Cabral de Melo Neto", incluído em Convergência (1970), dedica a primeira parte alternando as semelhanças - "Comigo e contigo" - e as diferenças - "Entre mim e ti":

Comigo e contigo o Brasil.

Comigo e contigo a Espanha.

Entre mim e ti a caatinga.

Entre mim e ti a montanha.

Comigo e contigo Velázquez,

Graciliano, o moriles.

Entre mim e ti o barroco,

A cruz, Antonio Gaudí.

Comigo e contigo o Andalu, Flamenco, Écija, los toros. (PCP, 691)

Murilo ratifica que a Espanha de Cabral é mais "restringida", no caso, representada por Velazquez, a Andaluzia, o flamenco e as touradas. Já a sua Espanha, além da parte "materialista", envolve o catolicismo - "a cruz" - e correntes e artistas que para Cabral seriam marcados por "excessos" e "rebuscamentos" Barroco e Antonio Gaudí.

A crítica algumas vezes chamou a atenção para as possíveis aproximações entre Cabral e Murilo. Já por volta de 1956 os dois apareceram juntos na série da gravadora Festa, na qual, em um disco, uma dupla de poetas brasileiros recitava seus próprios poemas. Na capa de cada disco, um crítico renomado escrevia um texto de apresentação. Cabral e Murilo, o décimo volume, coube a Tristão de Ataíde, 
cuja militância cristã diferencia os dois pela "presença de Deus": "O que encontramos na poesia de Murilo Mendes como na de João Cabral é a mesma sobriedade incisiva, a mesma graça hieroglífica, a mesma concisão cristalina, um senso parecido de 'humor', a mesma predominância dos metais sobre as cordas, em oposição ao que encontramos na estilística, mesmo dos mais modernos 'românticos' (....) Mas entre Murilo e João Cabral há esta outra diferença: naquele a constante presença de Deus, na aridez dos desertos humanos: neste a 'ausência', que nem a 'bola', nem o 'relógio', nem a 'faca', os três símbolos de sua poética máscula, ascética e inflexível consegue substituir."32

Quando da publicação em Lisboa de Tempo espanhol (1959) e Quaderna (1960), o crítico português João Gaspar Simões aproveita para considerar que "Murilo Mendes e Melo Neto representam, exactamente, correntes líricas de uma índole em que os valores 'modernistas' deixaram de se apresentar combativos, para se tornarem como que clássicos: clássicos do próprio modernismo."33

Tendo em vista um artista espanhol caro aos dois poetas, João Alexandre Barbosa, em passagem do estudo $A$ imitação da forma (1975), tratou de "verificar em que medida a 'leitura' de João Cabral se diferencia da de Murilo Mendes acerca de um mesmo objeto: o pintor Joan Miró". 34

Mais recentemente, em números de periódicos dedicados a Cabral e Murilo, retomou-se o tópico do contraste entre os dois. Joana Matos Fria, em "'Um olhar nítido como um girassol': João Cabral e Murilo Mendes" expõe que a incorporação de uma tendência "realista" da literatura espanhola "reposiciona a atitude onirista com que iniciaram as respectivas obras poéticas." 35 Por sua vez, Eucanaã Ferraz, em "Murilo Mendes e João Cabral: o sim contra o sim", a partir da carta de 1959 citada acima, insiste na nota dissonante: “(..) a Espanha cabralina parace-nos

\footnotetext{
${ }^{32}$ V. Anexos. Julio Castañon Guimarães aponta que "esses comentários se circuncrevem ao plano das obras literárias: seria possível pensar as aproximações e distanciamentos no plano mesmo das leituras. Talvez a comparação das peculiaridades de leitura pudesse ajudar a perceber o que a audição seria capaz de extrair de cada leitura em termos de papel que acaso desempenhassem na compreensão dos textos. No caso de João Cabral e Murilo, seria possível pensar em como são bem distintas suas leituras e em como essas distinções podem ter a ver não apenas com as peculiaridades pessoais, mas com as características da poesia de cada um e com a noção que cada um tem de sua própria poesia." (Cabral falando. Teresa revista de Literatura Brasileira. Área de Literatura Brasileira. FFLCH. USP. n. 3, São Paulo: Ed. 34, 2002, p. 304-307).

${ }_{33}$ SIMÕES, João Gaspar. Murilo Mendes e João Cabral de Melo Neto In Crítica II. Poetas contemporâneos (1946-1961). Lisboa: Delfos, s.d., p. 339-346.

${ }^{34}$ BARBOSA, João Alexandre. A imitação da forma: uma leitura de João Cabral de Melo Neto. São Paulo: Duas Cidades, 1975, p. 23-28.
} 
menos Espanha. Surge-nos, efetivamente, mais deformada que a de Murilo, que é muito mais matizada, sutil e dialógica. A de Cabral tem uma voz única, é a 'palo seco"'. 36

Apesar das pertinentes considerações, não há um trabalho de fôlego que analise a presença crucial da Espanha, enquanto tema e referência literária e cultural, na obra de Cabral e Murilo.

O primeiro aspecto a ser estudado, nos capítulos 1 e 2 , é a recepção da poesia espanhola, cuja presença em depoimentos, cartas, traduções, epígrafes e poemas, mostra-se decisiva para configurar as obras de ambos. Também a recepção dos dois brasileiros por alguns poetas espanhóis completa um quadro de mútua contribuição.

Principalmente nessa parte, revelou-se fundamental a pesquisa em acervos de escritores espanhóis, particulares ou públicos, espalhados pelas cidades natais dos escritores, do Puerto de Santa María em Cadiz (Fundación Rafael Alberti) a Barcelona (Fundación Joan Brossa). Até mesmo partes do Acervo de um escritor distribuem-se por diferentes instituições. Em relação ao poeta Jorge Guillén, por exemplo, a Fundação que leva seu nome na cidade de Valladolid não guarda nenhum documento ou livro seu. O arquivo pode ser consultado na Biblioteca Nacional em Madri, enquanto os livros que pertenceram a Guillén foram transferidos à Biblioteca Pública de Valladolid.

Apesar da dispersão de alguns acervos, identificamos uma rede formada por textos publicados, manuscritos, correspondência e livros com possíveis dedicatórias e / ou anotações marginais e apensas. Tal trabalho oferece fundamentação à crítica genética, à história e crítica literárias, e a diferentes tipos de edições. No âmbito nacional, devem-se destacar como referência obrigatória os projetos organizados a partir do Acervo Mário de Andrade pela Profa. Telê Ancona Lopez no Instituto de Estudos Brasileiros da USP. ${ }^{37}$

Ao consultar os acervos, é possível estabelecer uma cronologia, do encontro inicial aos últimos momentos, pelas datas e locais das dedicatórias nos livros e da correspondência. A recepção das obras materializa-se na presença do exemplar na

35 Colóquio/ Letras. Paisagem tipográfica. Homenagem a João Cabral de Melo Neto (1920-1999). Lisboa, n. 157-158, jul.-dez. 2000, p. 73.

${ }^{36}$ Ipotesi. Revista de estudos literários. v. 6, n.1, Juiz de Fora, 2002, p. 112. 
biblioteca do escritor, que pode conter anotações à margem, trechos sublinhados ou uma folha apensa manuscrita. Esse conjunto, que dá ao livro o status de manuscrito, permite-nos comprovar desde a epígrafe ou citação que nos suscitaram a pesquisa até um elemento que servirá de subsídio para a criação, por exemplo, de uma imagem poética. Por outro lado, o volume, que por alguma razão extraviou-se das estantes, talvez tenha recebido um comentário em uma carta, completando a biblioteca do escritor. O epistolário, aliás, constitui-se um ponto nevrálgico da rede do acervo, pois nele se anunciam o envio e o recebimento de livros, revistas, recortes, manuscritos, fotos, e suas respectivas apreciações.

Tal levantamento possibilitou-nos enriquecer a parte "Anexos", que reúne um conjunto de documentos e informações pouco conhecidos ou inéditos da relação de Cabral e Murilo com a Espanha. A fim de defender o trabalho com fontes, que muitas vezes é desvalorizado na análise literária, retomo as palavras de Sérgio Buarque de Holanda, em sua dupla condição de crítico e historiador, a respeito da importância do ensaio Joan Miró de Cabral: "Para bem entender um poeta, com a visão necessariamente relativista que pertence a toda crítica séria, importa procurála inclusive fora de sua obra poética e também, se possível, fora de seus escritos. Nada, neste caso, é inteiramente inútil, nada se perderá, para uma interpretação conscienciosa, ainda quando atinente apenas aos dados estéticos." 38

Os capítulos 3 e 4 versam sobre as artes plásticas espanholas, as quais, tanto em poemas, quanto em ensaios críticos, tornaram-se um campo privilegiado de reflexão sobre a própria obra, na medida em que as noções de visualidade e plasticidade fundamentam suas poesias.

Por último, apresentadas as fontes poéticas e pictóricas, nos capítulos 5 e 6 , estudamos os temas propriamente ditos: a paisagem, a tauromaquia e o flamenco, em Cabral, e o tempo, em Murilo.

Ainda é válida a proposta do escritor Otto Lara Resende sobre essa vertente: "Olhos acesos, em brasas, Murilo viu e amou a Espanha, de que deu rico testemunho. Como João Cabral de Melo Neto, outro poeta, outra visão. Eis aí um

\footnotetext{
${ }^{37}$ V. LOPEZ, Telê Ancona. A biblioteca de Mário de Andrade: seara e celeiro da criação. Em: Fronteiras da criação: anais do $6^{\circ}$ Encontro Internacional de Pesquisadores do Manuscrito. São Paulo: Annablume: Fapesp, 2000, p. 139-162.

${ }^{38}$ HOLANDA, Sérgio Buarque de. "João Cabral de Melo Neto" In O espírito e a letra. Estudos de crítica literária. v. 2. 1948-1959. Edição de Antonio Arnoni Prado. São Paulo: Companhia das Letras, 1996, p. 518.
} 
estudo a fazer - os dois poetas, as duas sensibilidades; a Espanha, as muitas Espanhas". 39

${ }^{39}$ Guernica, meu amor. O Globo, Rio de Janeiro, 3 maio 1977 (MAMEDE, Zila. Op. cit., p. 438). 


\section{CAPÍTULO 1: Leituras e leitores espanhóis de Cabral}

Depois de quase dez anos de sua descoberta da literatura espanhola, Cabral publicou a segunda reunião de sua poesia, intitulada Duas águas (1956). Mais do que apresentar sua produção completa até aquele momento, operava uma instigante avaliação de sua própria obra, como é descrito na orelha da edição:

"(...) querem corresponder a duas intenções do autor e - decorrentemente a duas maneiras de apreensão por parte do leitor ou ouvinte: de um lado, poemas para serem lidos em silêncio, numa comunicação a dois, poemas cujo aprofundamento temático quase sempre concentrado exige mais do que leitura, releitura; de outro lado, poemas para auditório, numa comunicação múltipla, poemas que, menos que lidos, podem ser ouvidos. Noutros termos, o poeta alterna o esforço de melhor expressão com o de melhor comunicação." ${ }^{40}$

Dessa maneira, fazem parte da "primeira água", os inéditos Uma faca só lâmina, 1955, e Paisagens com figuras, 1954-1955, e os publicados O cão sem plumas (1950), Psicologia da composição (1947), O engenheiro (1945) e Pedra do sono (1942); e da "segunda água", o inédito Morte e vida Severina, Auto de Natal Pernambucano, 1954-1955, e os editados O rio (1954) e Os três mal-amados (1943). Tal disposição desarticulava o conjunto de obras de uma fase "social", muito presente na fortuna crítica do poeta, formada por $O$ cão sem plumas, $O$ rio e Morte e vida Severina, já que o primeiro integra a "primeira água", e Os três malamados, sem essa perspectiva, figura na "segunda água". Como bem observou Alceu Amoroso Lima: "Como o título do livro indica, Duas águas (no sentido arquitetônico mas também metafórico), o autor, em vez de tomar partido na querela que divide os poetas das novas gerações em herméticos e sociais ou entre expressivos e comunicativos, partiu de ambas posições, mas não simultaneamente. Ora domina os poemas uma intenção metafórica, que permite ao

\footnotetext{
${ }^{40}$ Duas águas (Rio de Janeiro: José Olympio, 1956) Apud MAMEDE, Zila. Op. cit., p. 358-359.
} 
leitor uma ampla colaboração na interpretação dos mesmos, ora domina a realidade exterior, a típica e trágica natureza nordestina, (....)".41

As "duas águas", ou ainda, as vertentes da "expressão" e da "comunicação", percorrem a obra cabralina desde o seu início. A "poesia pura" de Mallarmé e Valéry e os príncipios construtivistas do cubismo constituíam os primeiros parâmetros de sua poesia. Embora se unissem a essas referências os poetas modernistas brasileiros, como Murilo ${ }^{42}$ e a forte presença de Drummond, Cabral não seguia uma das mais férteis lições do grupo: o aproveitamento de uma linguagem coloquial ou prosaica. Além disso, distanciava-se do programa nacionalista do movimento. Murilo, ao apresentá-lo em 1940, percebia que se tratava de "um poeta sem cor local. Tanto pode ser do Recife, como de Marselha ou Shangai “. 43

No entanto, antes mesmo de lançar Pedra do sono, revelou suas apreensões por essa postura e anseios de mudança em carta a Drummond de 23 de novembro de 1941, sob a impressão da leitura de Sentimento do mundo (1940): “(...) É que a perspectiva da publicação desse livro me tem deixado num estado quase de pânico. Sinto que não é esta a poesia que eu gostaria de escrever; o que eu gostaria é de falar numa linguagem mais compreensível desse mundo de que os jornais nos dão notícia todos os dias, cujo barulho chega até nossa porta; uma coisa menos 'cubista'." 44 A resposta foi animadora: "Eu acredito de certo que sua fase poética atual é fase de transição que v., com métodos, inclusive os mais velhos, está procurando caminho, e que há muita coisa ainda a fazer antes de chegarmos a uma poesia integrada ao nosso tempo, que o exprima limpidamente e que ao mesmo tempo o supere." ${ }^{\circ 5}$

\footnotetext{
41 "Duas Águas", de João Cabral de Melo Neto. Jornal do Comércio. Rio de Janeiro, 5 fev. 1957, p. 5. (Idem, ibidem, p. 07).

${ }^{42} \mathrm{~V}$. Introdução.

${ }^{43}$ GUIMARÃES, Julio Castañon, org. Op. cit., p. 57.

${ }^{44}$ SÜSSEKIND, Flora, org. Op. cit., p. 171. Antonio Candido, no artigo "Poesia ao norte" publicado na Folha da Manhã de 13 de junho de 1943, assinalou o risco de ausência de comunicação em Pedra do sono: "(...) Pureza poética, surrealismo, cubismo - coisas que estão soando agora como requinte, mesmo quando tão talentosamente representados por alguém como o nosso poeta.// $\mathrm{O}$ erro de sua poesia é que, construindo o mundo fechado de que falei, ela tende a se bastar a si mesma. Ganha uma beleza meio geométrica e se isola, por isso mesmo, do sentido de comunicação que justifica neste momento a obra de arte. Poesia assim autonomamente construída se isola no seu hermetismo." (Textos de intervenção. Edição de Vinícius Dantas. São Paulo: Duas Cidades; Ed. 34, 2002, p. 140)

${ }^{45}$ Idem, ibidem, p. 175.
} 
No final de 1942, voltou a abordar a tensão entre uma poesia centrada apenas na sua linguagem e sua comunicação, no texto "Prática de Mallarmé", estampado na revista Renovação, em homenagem ao centenário do poeta. A "grande lição prática" de Mallarmé encontrava-se em sua "alta consciência artística", centrada na palavra, a respeito da qual Cabral lança uma pedra fundadora de sua poética: "se tem visto a palavra menos como o material (material sólido, como a cor, o som, o gesso) sobre que se exerce a ação do poeta, do que como as singularidades de sua voz. Menos o Logos do que o Sermo." ${ }^{46}$ Por outro lado, finaliza o artigo apontando que Mallarmé levou sua experiência às últimas conseqüências ao negar as possibilidades comunicativas da palavra:

"Mallarmé compreendeu a linguagem como se a houvesse inventado", escreveu Valéry. E eu acrescento que esse tratamento a que ele submeteu a palavra, esse movimento em direção das fontes primitivas da palavra (donde o ar antiqüíssimo dessa poesia entretanto atual), em vez de ser uma prática que lhe trouxesse o domínio racional dos meios de expressão (o objetivo do jornalista, do escrivão, do professor; o objetivo de todos os que usam da palavra o seu valor de troca em idéias), foi sobretudo a tentativa de apreender as ressonâncias secretas de sua matéria. Ressonâncias que permanecem através do tempo e espaço (próprias portanto de sua matéria) e cujos efeitos o poeta, por uma técnica de obscurecimento voluntário quis purificar completamente, numa tentativa de destruir a presença em nosso espírito (fenômeno que em nosso mundo lógico não mais podemos evitar senão a preço de uma disciplina e de rigores que, curiosamente, nos acostumamos a ver como anti-poéticos) do objeto ou do conceito que a palavra representa no universo que conversa e dá nome às coisas.

Cabral, portanto, não compartilhava a incomunicação de Mallarmé, buscando nos poemas d'O engenheiro, iniciado nesse 1942, a palavra em seu "valor de troca em idéias" e representando o objeto ou o conceito "no universo que conversa e dá nome às coisas". Instaura um "mundo justo", claro e sólido, a partir das metáforas da construção, presentes tanto no poema que dá título à coletânea, quanto na epígrafe do arquiteto Le Corbusier. Assim mesmo, Cabral não escapou de ser rotulado em um grupo de poetas publicados entre 1944 e 1945, caracterizados pelo cuidado

\footnotetext{
$\overline{46}$ “Prática de Mallarmé”. Renovação. Nova Série. a. 4, n. 1, Recife, out-nov-dez 1942.
} 
formal, de dicção solene, e logo auto-proclamado como "Geração de 45", que possuía como um dos objetivos suplantar a experiência prosaica e nacionalista do Modernismo.

A observação de Murilo sobre a ausência de "cor local" continuava a valer, a não ser por um Recife "aquático" em "A Joaquim Cardozo": "a cidade que não consegues/ esquecer/ aflorada no mar: Recife,/ arrecifes, marés, maresias;". ${ }^{47} \mathrm{Em}$ 1943, enquanto ainda se encontrava às voltas com $O$ engenheiro, estreava na "segunda água" com Os três mal-amados. Como vimos, isso não implicava uma obra comprometida, mas se destinava a um "ouvinte" os três monólogos alternados de João, Raimundo e Joaquim expurgando seus amores. ${ }^{48}$ No caso do amor "devorador" de Joaquim, que tudo consome, inclusive a paisagem em que se insere, deixa entrever Pernambuco e Recife:

O amor comeu meu Estado e minha cidade. Drenou a água morta dos mangues, aboliu a maré. Comeu os mangues crespos e de folhas duras, comeu o verde ácido das plantas de cana cobrindo os morros regulares, cortados pelas barreiras vermelhas, pelo trenzinho preto, pelas chaminés. Comeu o cheiro de cana cortada e o cheiro de maresia. Comeu até essas coisas de que eu desesperava por não saber falar delas em verso. (SA, 11)

Destacam-se a objetividade e plasticidade da descrição, próxima dos romances nordestinos da década de 30 - especialmente José Lins do Rego -, mais de uma vez valorizados por Cabral. Porém, a última frase retoma a angústia compartilhada com Drummond: a linguagem já era menos "cubista", mas ainda não possuía meios para expressar o mundo dos homens.

Reforçou a "primeira água" nos três poemas que formam Psicologia da composição, nos quais reflete sobre o fazer poético. Iniciado no Brasil em 1946, levou a cabo o conjunto no ano seguinte na Espanha. A partir de seu intenso contato com a poesia desse país, o que parecia limitar-se à "primeira água" pôde se

\footnotetext{
${ }^{47}$ Serial e antes. Rio de Janeiro: Nova Fronteira, 1997, p. 46. A partir daqui, essa edição passa a ser indicada por SA.

48 "(...) Chegando aqui [ao Rio] vi aquele poema do Carlos Drummond, o "Quadrilha”, achei que podia escrever uma peça de teatro dentro do mesmo tema. Não uma peça de bulevar, mas de teatro hierático. O monólogo dos três personagens masculinos saiu bem, só que fui incapaz de escrever o monólogo das três mulheres, que deveria ser intercalado com o dos homens. Aí, abandonei a idéia de escrever uma peça." (ATHAYDE, Félix, org. Op. cit., p. 101-102)
} 
configurar em "duas águas". Contudo, posteriormente Cabral percebeu a limitação da classificação de sua obra: “(...) as minhas Duas águas não se reúnem num ponto porque as minhas Duas águas são uma faixa, porque depois de $O$ rio e Morte e vida Severina eu vi que essa tentativa de extensão de cultura tinha fracassado completamente, porque enquanto eu escrevia O rio e Morte e vida Severina escrevia imaginando que fossem lidos no Mercado de São José ou em Limoeiro, por cantador daqueles, né? (...) essa minha Duas águas acabou com esses dois livros. Depois daí então eu resolvi fazer a minha poesia independente dessa preocupação. Eu creio que foi uma idéia um pouco ingênua, compreende?"49

Analisamos quatro momentos do processo de conjugação das "duas águas": o primeiro ano na Espanha, 1947, em meio à descoberta da poesia espanhola, deteve-se em dois poetas decisivos da chamada Geração de 27, Jorge Guillén e Rafael Alberti; entre 1948 e 1950, ampliou seu horizonte com a poesia catalã, praticando a tradução e relacionando-se com Carles Riba e Joan Brossa; entre 1951 e 1954, incorporou a poesia medieval espanhola a sua obra, principalmente o Poema de Mio Cid e Gonzalo de Berceo; e na década de 60, tornou-se um referencial para os poetas e tradutores Ángel Crespo e Gabino-Alejandro Carriedo.

\section{Uma epígrafe e dois poemas: Jorge Guillén e Rafael Alberti}

Psicologia da composição traz como epígrafe o verso "Riguroso horizonte", do poeta Jorge Guillén. Diante de um pedido de Bandeira para encontrar o livro Cántico, de Guillén, o poeta diplomata comenta em carta de 5 de novembro de 1947:

(...) o livro do Guillén é inexistente. Para lê-lo, tive de ir à biblioteca daqui, que possui a edição de 1937 ou 1939. Como v. sabe, o Guillén só tem, publicado, este livro, que vai sempre aumentando nas sucessivas edições. Li que estava preparando uma nova. Assim que sair comprarei um exemplar para v. Gostei de seu interesse pelo vallisoletano. Acho-o excelente. Não o conhecia - nem de nome - até chegar aqui. Lido porém, o homem me conquistou. ${ }^{50}$

\footnotetext{
${ }^{49}$ Entrevista ao Diário de Pernambuco, Recife, 21 de out. 1979.

${ }^{50}$ SÜSSEKIND, Flora, org. Op. cit., p. 45.
} 
Cántico teve quatro edições ampliadas sucessivamente: 1928, 1936, 1945 e 1950. O verso "Riguroso horizonte" abre o poema "El horizonte":

Riguroso horizonte.

Cielo y campo ya idénticos,

Son puros ya: su línea.

Perfección. Se da fin

A la ausencia del aire,

De repente evidente.

Pero la luz resbala

Sin fin sobre los límites.

¡Oh perfección abierta!

Horizonte, horizonte

Trémulo, casi trémulo

De su don inminente.

Se sostiene en un hilo

La frágil, la difícil

Profundidad del mundo.

El aire estará en colmo

Dorado, duro, cierto.

Transparencia cuajada.

Ya el espacio se comba.

Dócil, ágil, alegre

Sobre esa espera - mía. ${ }^{51}$

Ao lado de riguroso, o léxico do poema, como o de muitos outros de Cántico, sintetiza a objetividade e construção visadas por Cabral: puros - evidente perfección - duro - cierto - transparencia.

Apesar das aproximações em relação a Guillén, Cabral ressaltou uma significativa divergência: "Tenho a impressão de que devo muito da minha obsessão pela simetria e do meu intelectualismo à poesia de Jorge Guillén, até a reunião da sua obra no livro Cântico. (...) o curioso dessa influência é que há uma diferença essencial entre mim e o Jorge Guillén. Sinto que ele é um poeta muito mais abstrato do que eu(...)". ${ }^{52}$ Ainda segundo Luiz Costa Lima, o "júbilo perante as coisas" da

\footnotetext{
${ }^{51}$ GUILLÉN, Jorge. Cántico. $4^{a}$ ed. Barcelona: Seix Barral, 1998, p. 177.

${ }^{52}$ Entrevista a Mario Chamie (MAMEDE, Zila. Op. cit., p. 155).
} 
poesia de Guillén "não encontra paralelo na neutralidade com que se nomeia" na poesia cabralina. $^{53}$

A identificação não era apenas por parte de Cabral. Guillén possuía em sua biblioteca exemplares dedicados de Psicologia da composição e Terceira feira (1961, contendo Quaderna, Dois parlamentos e Serial). ${ }^{54}$ Gostou do selo O Livro Inconsútil, chegando a pedir a Cabral para "fazer uma pequena edição de seus poemas" 55 , que não se concretizou. Além disso, a existência em seu arquivo de fotocópias de poemas do poeta brasileiro indica uma leitura mais atenta. Tradutor de "El cementerio marino" em 1938, conservou "A Paul Valery", de O engenheiro, com uma cruzeta. Junto a esse, reuniu quase todos os poemas referentes à Espanha de Paisagens com figuras: "Medinaceli", "Imagens em Castela", "Fábula de Joan Brossa", "Campo de Tarragona", "Encontro com um poeta", "Alguns toureiros", "Outro rio: o Ebro" e "Duas paisagens", dos quais "Imagens em Castela" e "Alguns toureiros" mereceram uma cruzeta. No caso do segundo, provavelmente Guillén interessou-se pela "lição de poesia", que se esboçara ainda em 1947, quando Cabral viu Manolete e imaginou que era Valéry toureando ${ }^{56}$ :

\author{
$(\ldots)$ \\ como domar a explosão \\ com mão serena e contida, \\ sem deixar que se derrame, \\ a flor que traz escondida, \\ e como, então, trabalhá-la \\ com mão certa, pouca e extrema: \\ sem perfumar sua flor, \\ sem poetizar seu poema. (SA, 132)
}

\footnotetext{
${ }^{53}$ LIMA, Luis Costa. Lira e antilira: Mário, Drummond, Cabral. $2^{\mathrm{a}}$ ed. Rio de Janeiro: Topbooks, 1995, p. 237-246. João Alexandre Barbosa também comenta a relação Cabral-Guillén ( $A$ imitação da forma. Op. cit., p. 58-60).

${ }^{54} \mathrm{~V}$. Anexos, "Dedicatórias autógrafas em livros".

${ }^{55}$ Carta a Manuel Bandeira de 18 de julho de 1948 (SÜSSEKIND, Flora, org. Op. cit., p. 82).

${ }^{56}$ Carta a Manuel Bandeira de 4 de setembro (SÜSSEKIND, Flora, org. Op. cit., p. 34).
} 
No ano de chegada à Espanha, Cabral interessou-se por outro poeta que integrou a Geração de 27, cujo fruto foi a publicação das duas versões do poema "Fábula de Rafael Alberti" em Museu de tudo (1975):

Do anjo marinheiro (asas azuis a gola da blusa azul, bolsa de azul do mar); do anjo teológico, não em ovo gerado, puros frutos de ar como maçãs de vento; do anjo venenoso, serpente emboscada no tufo das palavras - o fluido jogo abandonou.

Fez o caminho inverso: do vapor à gota de água (não, da vida ao sono, ao sonho, ao santo); foi da palavra à coisa, seja dolorosa a coisa, seja áspera, lenta, difícil a coisa.

(1947)

Do anjo marinheiro (asas azuis a gola da blusa azul, enfunada de azul do mar); do anjo teológico (não em ovo gerado, frutos virgens, do ar, castas maçãs do vento); enfim, do anjo barroco (cobra má, enroscada no mato dicionário)

- o jogo aéreo abandonou.

Fez o caminho inverso:

não foi da coisa ao sonho, ao nome, à sombra;

foi do vapor de água

à gota em que condensa;

foi da palavra à coisa:

árdua que seja,

ou demorada, a coisa;

seja áspera ou arisca,

em sua coisa, a coisa; 
seja doída, pesada,

seja enfim coisa a coisa.

$$
(1963)^{57}
$$

O poema de 1947 foi publicado em 1953 e 1957, respectivamente em dois periódicos. ${ }^{58}$ Dezesseis anos depois, ainda despertou a atenção de Cabral, levandoo a elaborar uma segunda versão. Em lugar de descartar a primeira, inseriu-a na variada coletânea Museu de tudo, seguida pela de 1963. Nesse mesmo ano, começou a compor $A$ educação pela pedra, cujos poemas dividem-se pelo mesmo símbolo de "Fábula de Rafael Alberti" ou pelo número 2. A opção de publicar as duas versões em Museu de tudo acompanha a estrutura binária imposta à coletânea de 1966. Assim, para um mesmo tema, as imagens e os significados duplicam-se e permutam-se.

Rafael Alberti, em sua extensa e frutífera trajetória - da década de 20 à de 80 - passou por vários movimentos da poesia do século XX. Talvez o poeta brasileiro tivesse em mãos a $2^{\text {a }}$ edição de Poesía (1924-1944), de 1946, da editora argentina Losada, que reúne de Marinero en tierra (1924) a Pleamar (1942-1944).

Ao considerar que o tema da Espanha somente aparecerá em Paisagens com figuras, 1954-1955, pode-se concluir que não foi dada a devida importância ao primeiro poema de Cabral a respeito de um poeta espanhol, "perdido", muitos anos depois, em meio aos 80 poemas de Museu de tudo. Pretende-se, a partir de uma análise detida, configurar "Fábula de Rafael Alberti" como confluência tanto de uma recepção da poesia espanhola, quanto de uma auto-avaliação da poesia cabralina. Com a publicação de Psicologia da composição, também em 1947, sua trajetória poética chegava a um ponto crucial. Em "Fábula de Rafael Alberti" sedimentava o que já realizara e lançava as bases do trabalho a seguir. Falando de Alberti, estava examinando a si mesmo e a sua poesia, processo reiterado ao longo da obra, não só em relação a escritores, mas também a pintores, toureiros, etc.

$\mathrm{Na}$ primeira estrofe, a imagem anjo retoma ostensivamente uma das principais obras de Alberti, Sobre los ángeles (1929). O anjo desdobra-se em três, caracterizados como marinheiro, teológico e venenoso (1947) / barroco $(1963)^{59}$, os

\footnotetext{
${ }^{57}$ A educação pela pedra e depois. Rio de Janeiro: Nova Fronteira, 1997, p. 87-88. A partir daqui, essa edição passa a ser indicada por EPD.

58 Pequenos Cadernos de Poesia. Rio de Janeiro, (1):7-8, out. 1953; O Tempo e o Modo. Lisboa, (50):161-2, 1957. (MAMEDE, Zila. Op. cit., p. 48-49).

${ }^{59}$ Para diferenciar as duas versões, anotaremos as respectivas datas entre parênteses.
} 
quais metaforizam três fases poéticas, além de serem personagens adequados ao universo da "fábula". Sintaticamente, operam como três complementos do verso final da estrofe, julgamento dessas etapas - "o fluido jogo abandonou" (1947) / "o jogo aéreo abandonou" (1963) - , podendo ser entendidos como abandonos, ou ainda, recusas do próprio Cabral.

Os três momentos da poesia de Alberti concentram-se na agitada década de 20, quando ele publicou nada menos que 7 livros. O "anjo marinheiro" relaciona-se à obra de estréia, Marinero en tierra, motivado pela nostalgia do mar da cidade natal, Puerto de Santa María, em Cádiz. Impulsionou, na poesia espanhola do período, a corrente denominada de "neopopular", na medida em que atualizou a forma e os motivos da lírica popular. Como o próprio Alberti declarou, entre suas fontes incluía a melhor tradição da poesia ibérica: Gil Vicente e os cancioneiros dos séculos XV e $\mathrm{XVI}$.

No poema de Cabral, o "anjo marinheiro" é tomado pela onipresença da cor azul, que do mar transfere-se aos seres e objetos, retomando o verso "la blusa azul ultramar"60 de Alberti. Na versão de 1963, a acessória bolsa torna-se o particípio passado "enfunada", dinamizando a imagem pelo efeito poderoso do "azul do mar" em lugar do vento. A substituição permite que se identifique uma ressonância mais direta do segundo poema de Marinero en tierra:

\footnotetext{
Gimiendo por ver el mar, un marinerito en tierra iza al aire este lamento:

"¡Ay mi blusa marinera! Siempre me la inflaba el viento al divisar la escollera."
}

O primeiro momento da poesia de Alberti, abrangendo as duas obras seguintes - La amante (1925) e El alba de alhelí (1925-1926) - não atendia às exigências de um Cabral que desde seu primeiro livro, Pedra do sono, não fazia concessões a um lirismo mais confessional.

O segundo anjo, batizado de "teológico", representa o já mencionado Sobre los ángeles, escrito entre 1927 e 1928. O qualificativo comporta reminiscências

\footnotetext{
${ }^{60}$ ALBERTI, Rafael. Poesia (1924-1944). $2^{a}$ ed. Buenos Aires: Editora Losada, 1946, p. 16.

${ }^{61}$ Idem, ibidem, p.12.
} 
bíblicas suscitadas pela multidão de anjos da coletânea. Considerado um dos mais significativos exemplos do surrealismo na literatura espanhola, em "Fábula de Rafael Alberti", Cabral avalia não apenas essa obra, mas também a vanguarda francesa da qual se aproximou no início de sua poesia. Ratificando uma ascendência divina, indica-se uma origem não natural para o anjo teológico, pois não é gerado em ovo. Se por um lado se exclui uma vinculação ao reino animal, por outro, refere-se ao vegetal a partir de "frutas", em seguida restringidas a "maçãs", destituídas, portanto, de sensibilidade e movimento. Os adjetivos "puros" (1947) / "virgens" e "castas" (1963) reforçam a ausência de qualquer vínculo com uma natureza ou um entorno. Uma discreta diferença entre as versões de 1947 e de 1963 atribui de forma lapidar uma etérea procedência ao anjo teológico: na primeira, os frutos são de ar e as maçãs de vento, ou seja, não palpáveis; já na segunda, os frutos são do ar e as maçãs do vento, ou seja, livres, soltos. Nos dois casos, tanto Sobre los ángeles, quanto o surrealismo, são avaliados como fantasiosos e literalmente "sem os pés no chão". Além disso, as imagens ar e vento remetem à sentença do final da estrofe, a qual não quer significar apenas que Alberti abandonou o "jogo aéreo" (1963), mas também que Cabral não compartilha dele, mais especificamente, do surrealismo.

Resta o terceiro e último anjo, "venenoso" (1947)/ "barroco" (1963). O termo barroco, utilizado no século XIX por Heinrich Wölflin para classificar a arte do século $X V I I$, elucida essa fase da poesia de Alberti, a da obra Cal y tierra, publicada no mesmo ano de Sobre los ángeles, mas escrita entre 1926 e 1927, período da retomada de Góngora pelos jovens poetas espanhóis. ${ }^{62}$ De acordo com o amigo Dámaso Alonso, Alberti apresentava-se como um dos mais entusiasmados conhecedores da obra do poeta cordobês: “(...) Pero con quién yo más intercambiaba gongorismo era con Rafael Alberti. Rafael, completamente alejado entonces de cualquier preocupación que no fuese exclusivamente literaria, se sabía a Góngora de memoria. Él y yo podíamos recitar las Soledades y el Polifemo de memoria, sin más que alguna vacilación, en las que mutuamente nos ayudábamos." ${ }^{63} \mathrm{Em} \mathrm{Cal}$ y tierra, tal repertório possibilitou uma "paráfrasis incompleta" da Soledad tercera.

\footnotetext{
${ }^{62}$ V. Capítulo 2.

${ }^{63}$ ALONSO, Damaso. "Góngora entre sus dos centenarios (1927-1961)" In Cuatro poetas españoles (Garcilaso-Góngora-Maragall-Antonio Machado). Madri: Gredos, 1962, p. 61.
} 
Entre os três anjos, trata-se daquele que oferece perigo, ao se mostrar como "serpente" (1947)/ "cobra má" (1963). O adjetivo "venenoso" (1947) configura uma série de sentidos pejorativos de "barroco" (1963), de viés neoclássico e positivista, como "excesso", "deformação", "acúmulo", "hermetismo", "afetação", entre outros. ${ }^{64}$ Porém, ressalta-se a noção de "excesso" da linguagem como sendo a grande ameaça, na medida em que a serpente está "emboscada/ no tufo das palavras" (1947)/ "enroscada/ no mato dicionário" (1963). Mais uma vez, a proposta de Alberti opõe-se radicalmente ao estilo de Cabral, principalmente a partir d'O engenheiro, marcado pelo despojamento e clareza.

Os três momentos da poesia albertiana são vistos como "jogos", refletindo a intensa experimentação das vanguardas na década de 20, mas nada concretos "fluído" (1947)/ "aéreo" (1963). Ao repassar três tendências da poesia de Alberti, Cabral defende três posturas de contenção, fundamentais de sua poética: não dar vazão ao sentimentalismo, à imaginação e à linguagem.

Antes de prosseguir, vale lembrar que um dos três poemas que constituem Psicologia da composição chama-se "Fábula de Anfion", no qual a personagem mitológica, diante de Tebas construída, lamenta sua dimensão empírica, para em seguida revelar o desejo de uma cidade ideal, quase "aérea":

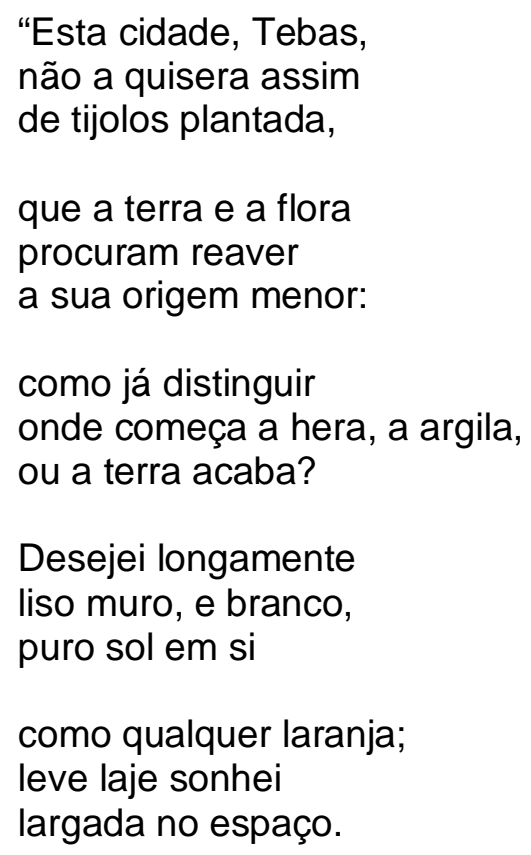

\footnotetext{
${ }^{64}$ V. HANSEN, João Adolfo. "Barroco, neobarroco e outras ruínas". Teresa revista de literatura brasileira. FFLCH - USP. Editora 34, n. 2, 2001, p. 10-66.
} 
Onde a cidade

volante, a nuvem

civil sonhada?" (SA, 58)

Como também data de 1947 a primeira versão de "Fábula de Rafael Alberti", a denominação por um mesmo gênero ${ }^{65}$ assinala que os dois poemas podem ser duas faces de uma "psicologia da composição": enquanto em "Fábula de Anfion" o criador lamenta o resultado "prosaico" do acaso, pois almejava perfeição e leveza, na segunda estrofe de "Fábula de Rafael Alberti" aponta para outra direção.

Cabral não se contentava apenas com o intelectualismo de um Guillén. A tumultuada década de 30, não só na Espanha, mas também pelo mundo afora, motivou em muitos escritores o engajamento político. No caso de Alberti, que entre outras ações aderiu ao Partido Comunista, deu início a uma poesia mais participativa, muito bem refletida no título da coletânea de 1938, El poeta en la calle, aliada a uma linguagem mais objetiva. Em artigo de 1936, incita a uma transformação da poesia espanhola:

(...) Hora es ya que cuando citemos el río, el trigo, el aire, el marinero o la carpintería lo hagamos profundamente, enterados e identificados con ellos, con sus fines, com todos sus problemas. Que al escribir un verso, ese verso nazca de un conocimiento exacto de las cosas elevadas a materia poética, y pueda comprobarse. En la más reciente poesía española se maneja con absoluta irresposabilidad e indiferencia todo lo existente, sin haberse el poeta molestado jamás en mirarlo, en saber si verdaderamente es cierto. Demasiado "viento", demasiados "pájaros, tumbas, muertes", cachorros y tragedias, que no pasan de ser puramente auditivos, que apenas nunca han bajado del oído, camino de la garganta. ${ }^{66}$

De acordo com o poema de Cabral, nessa fase da obra de Alberti, fez-se um "caminho inverso" ao da poesia ou da literatura mais convencionais, as quais partiriam da experiência - vida (1947) / coisa (1963) - para chegar a uma elaboração sublimada, mais etérea - sono, sonho, santo (1947) / sonho, nome,

\footnotetext{
${ }^{65}$ Em outros poemas de sua obra, Cabral valeu-se da denominação "fábula": "Fábula do Capiparibe" (O cão sem plumas), "Fábula de Joan Brossa" (Paisagens com figuras) e "Fábula do engenheiro" ( $A$ educação pela pedra).

${ }^{66}$ Apud BALLESTA, Juan Cano. La poesía española entre pureza y revolución (1920-1936). Madri: Siglo Veiniutno, 1996, p. 144-145.
} 
sombra (1963). Um fenômeno comum da natureza, a condensação dos gases, indica a mudança de rumo na poesia albertiana, que passou das "vaporosas" vanguardas da década de 20 para a conquista das coisas do mundo. $O$ genérico vocábulo coisa dimensiona uma ambiciosa posse. Retomando a "Fábula de Anfion", não se lamenta mais que a construção seja de "tijolos plantada" ou de "origem menor". Se esta termina com a angustiosa pergunta de como dominar ou prever o acaso que conduziu a flauta, em "Fábula de Rafael Alberti" responde-se a partir dos percalços que não invalidam o poema: os adjetivos dolorosa, áspera, lenta, difícil, arisca, pesada remetem ao trabalho de invençao contrário à espontaneidade, muitas vezes enfrentando o acaso, e como tema, as questões da sociedade contemporânea.

Ainda no âmbito da "Psicologia da composição", o vocábulo poético, metaforizado em objeto, passou do mineral - "que é mineral a palavra/ escrita, a fria natureza// da palavra escrita."- para a abrangente e prosaica coisa. A tautologia final do poema na versão de 1963 - "seja enfim coisa a coisa" - propõe uma concepção da poesia que esteja o mais próxima possível daquilo a que se refere. Posteriormente, na série de artigos de 1952 sobre a Geração de 45, a palavra reveste-se de materialidade enquanto se vincula à referência de um contexto empírico, contraposta ao universo poético do grupo, para o qual sugestivamente utiliza o qualificativo de "angélico": "O vocábulo prosaico está pesado de realidade, sujo de realidades inferiores, as do mundo exterior, e em atmosferas tão angélicas só pode servir de neutralizador." (grifo nossos). ${ }^{67}$

Portanto, logo em 1947, Cabral, a partir da leitura de Guillén e Alberti, reconheceu em sua própria obra as tensões da poesia espanhola na década anterior, dividida entre uma poesia "pura" e uma poesia "comprometida".

\section{Brasil e Catalunha}

Em carta de 30 de julho de 1947, Bandeira perguntou a Cabral sobre os "poetas da terra", pois na última edição de 1946 de sua obra Noções de história das literaturas incluíra algumas informações sobre a literatura catalã. Na resposta, em 4

\footnotetext{
67 Prosa.Rio de Janeiro: Nova Fronteira, 1998, p. 84. A partir daqui, essa edição passa a ser indicada por P.
} 
de setembro, Cabral comentou que estava imerso na poesia espanhola... em castelhano. No entanto, não se mostrou indiferente à questão do amigo. Já em carta de 17 de fevereiro de 1948 confessou que ela o fizera "criar vergonha": "Comecei a ler e a aprender a língua do país e em sua literatura descobri enormes coisas."68 Freqüentou a poesia catalã desde o século XIX, com Verdaguer e Costa i Llobera, chegando ao século XX com Alcober, Maragall, Carner, Guerau de Liost e LópezPicó. Vinha dedicando-se à tradução, principalmente das tankas, forma clássica da poesia japonesa cultivada na obra Del joc i del foc [Do jogo e do fogo] (1946) de Carles Riba (1893-1959). Considerado por Cabral o "melhor poeta catalão vivo", três de suas traduções foram divulgadas no número 16 de Ariel. Revista de Les Arts, de abril de 1948. O poeta Joan Triadú assinou uma nota intitulada "Brasil i Catalunya"69, na qual apresenta o poeta brasileiro com uma "nítida austeridade de expressão que se mantém na linha das proximidades Guillén-Riba, e de certa maneira, Valéry." Sugere, assim, uma linhagem de poetas conscientes em seu ofício, dos quais Cabral procurava se aproximar. No caso específico das tankas de Riba, a estrutura fechada de 31 sílabas e sua brevidade revelam-se como exemplo do "Riguroso horizonte" almejado.

Cabral conheceu Riba, oferecendo-Ihe nesse 1948 um exemplar dedicado de Psicologia da composição ${ }^{70}$ e recebendo-o para jantar, como indica uma carta de 24 de setembro de Riba a Joan Triadú. ${ }^{71}$

Por outro lado, Cabral não se limitou aos autores mais consagrados, interessando-se também pela obra dos mais jovens. Muitos deles tinham como mestre a Riba e estavam aglutinados em torno da mencionada revista Ariel, veículo de 1946 a 1951 da nova geração que queria retomar a tradição cultural catalã sufocada pela repressão do pós-guerra. Provavelmente Cabral acompanhava a produção recente pelas páginas de Ariel e pelo contato com os próprios poetas, como Joan Triadú.

A fim de divulgar a poesia catalã no Brasil, planejou uma antologia de 15 poetas, como informou Rosa Leveroni a Josep Palau i Fabre, dois poetas vertidos ao português por Cabral, em carta de 19 de novembro de 1948:

\footnotetext{
${ }^{68}$ SÜSSEKIND, Flora, org. Op. cit., p. 61.

${ }^{69} \mathrm{~V}$. Anexos.

${ }^{70}$ V. Anexos, Dedicatórias autógrafas em livros.

${ }^{71}$ V. GUARDIOLA, Carles-Jordi, org. Cartes de Carles Riba. v. 2. 1939-1952. Barcelona: Institut d'edutis catalans, 1991, p. 353.
} 
Pergunta-me notícias sobre a Antologia que prepara o Sr. João Cabral de Melo. Eu apenas posso dizer-Ihe que o pouco que sei disso, vai me informar um dia por telefone Joan Perucho, que me disse que este senhor preparava a edição no Brasil - eu acho - de suas traduções de 15 poetas nossos, e que entre eles ali estavam você e eu (é uma antologia de poesia jovem, embora creio que inclui também Manén e Garcés) e que perguntava com urgência dados biográficos (...) Quem poderia informar-lhe melhor, suponho, é Perucho mesmo. Eu, de todas as maneiras, quando o vir, pedir-lhe-ei mais informação, que terei muito prazer em mandar-lhe. ${ }^{72}$

A antologia foi publicada sob o título de Quinze poetas catalães ${ }^{73}$, em fevereiro de 1949, na Revista Brasileira de Poesia, periódico que divulgava, entre outros, os poetas da Geração de 45. Além de dados biográficos sumários, consta 0 poema original e a tradução em português. A ordem dos poetas obedece à cronologia do nascimento: 1898 (Marià Manent), 1899 (Joan Oliver), 1901 (Tomás Garcés), 1910 (Rosa Leveroni), 1913 (Bartolomé Rosselò-Porcel, Joan Teixidor e Salvador Espriu), 1914 (Joan Vinyoli), 1917 (Josep Romeu i Figueras e Josep Palau i Fabre), 1918 (Joan Barat), 1920 (Joan Perucho), 1921 (Joan Triadú), 1924 (Jordi Sarsanedas) e 1927 (Jordi Cots). Mais da metade eram jovens poetas como Cabral. A maioria dos poemas foi divulgada ou pertence a obras da década de 40, com exceção de La branca (1918), de Manent, Les decaptacions (1934), de Joan Oliver e Imitació del foc (1938), de Rosselò-Porcel. As resenhas de algumas obras desses autores, publicadas em Ariel ao longo de 1947, demarcam sua diversidade e possíveis pontos de interesse para Cabral: El Caçador, de Tomás Garcés, "se enlaça com linhas muito diversas da lírica antiga ou contemporânea. Veia folclórica; ressonâncias dos poetas franceses que exaltaram o subúrbio, as coisas humildes, a 'presença humana',"74; em Poemes, de Joan Barat, "uma notável e nobre gravidade impulsa os versos a desenvolver-se lentamente, às vezes majestuosamente, e parece como se ao autor the preocupasse mais a maneira como dirá aquilo que sente ou aquilo que pensa do que aquilo que sentiu e pensou" ${ }^{\text {"75; }}$ e em Cáncer, de

\footnotetext{
${ }^{72}$ Tradução do catalão ao português (BARENYS, Natàlia, org. Epistolari Rosa Leveroni-Josep Palau i Fabre. Barcelona: Publicacions de L'Abadia de Montserrat, 1998, p. 45).

${ }^{73} \mathrm{~V}$. Anexos.

${ }^{74}$ MANENT, Marià. "Notes sobre libres". Ariel. a. 2, n. 9, Barcelona, abril 1947, p. 31.

75 ROMEU I FIGUERAS, Josep. "Joan Barat: Poemes. - Barcelona, 1947". Ariel. a. 2, n. 10, Barcelona, jun. 1947, p. 48.
} 
Josep Palau Fabre, as "coisas são ditas de uma maneira exata, matemática, com uma clarividência fulminante". ${ }^{76}$

$\mathrm{Na}$ introdução, Cabral aproxima os vários autores pela "posição de defesa, defesa tensa, da língua catalã". Alude à luta dos poetas catalães contra a repressão lingüística imposta pelo governo de Franco, já que entende a poesia como "primordialmente, um uso de linguagem". A poesia deles, portanto, seria "mais de professores e filólogos do que de jornalistas, de conscientes do que de inspirados". Mais do que uma imagem, trata-se de uma comprovação, a começar por Riba, que foi professor de grego e tradutor de Homero e Virgílio. Além dele, Joan Triadú exerceu o cargo de leitor de catalão na Universidade de Liverpol (1948-1950), e Jordi Sarsanedas, o de leitor de castelhano e catalão na Universidade de Glasgow (1948-1950).

Ao mesmo tempo que caracteriza a situação específica de criação dos poetas catalães, Cabral expõe os princípios de sua poética. Eles assumem uma "atitude de autodisciplina e lucidez" em oposição a uma "atitude romântica de abandono à pura espontaneidade e uma cega - ou mais, justamente, enceguecida - entrega ao impulso de criar." E finaliza o texto com um sutil recado aos seus compatriotas, preocupados com a "solenidade" e "nobreza" da poesia: "E, agora, se me é permetida uma parte de julgamento, eu diria que essa atual posição a que foram levados os escritores catalães - uma posição materialista diante da criação poética - talvez contenha uma sugestão digna de ser considerada por parte de poetas de outros idiomas não ameaçados."

Nesse 1949, as relações de Cabral com a poesia catalã começaram a ocupar um cenário diferente, passando do grupo da revista Ariel para o de Dau al Set. Como lembrou Tapiès, os projetos dos dois grupos diferenciavam-se: "Les reconocíamos el mérito de haberse atrevido a llevar adelante aquella empresa cultural en catalán, pero nos parecía demasiado eclética, poco combativa, y sus 'ilustraciones' poco radicales y en cierto modo anticuadas." "77; “(...) nos considerábamos los rebeldes, los 'negros', los malditos, la rama izquierda de la cultura catalana. La mayor parte de los de Ariel, por ejemplo, entonces nos parecían

\footnotetext{
${ }^{76}$ PERUCHO, Joan. "Dos llibres de Josep Palau Fabre". Ariel. a. 2, n. 14, Barcelona, dez. 1947, p. 117.

77 TAPIÈS, Antoni. Memoria personal. Fragmento para una autobiografía. Trad. Javier Rubio Navarro e Pere Gimferrer. Barcelona: Seix Barral, 2003, p. 219.
} 
unos ángeles, representantes típicos de los intelectuales conservadores catalanes $(\ldots) "{ }^{78}$

Joan Brossa era o poeta do Dau al set. Cabral, em 1949, imprimiu na sua minerva 70 exemplares de Sonets de Caruixa, primeira obra publicada de Brossa. Este, por sua vez, no número de julho-agosto-setembro desse ano de Dau al Set, publicou suas traduções ao catalão de três poemas d'O engenheiro: "La Ballarina" ("A bailarina"), "Els núvols" ("As nuvens") e "El paisatge zero" ("A paisagem zero"). ${ }^{79}$ Em comum, ambos os poetas haviam incorporado elementos do surrealismo em suas obras iniciais.

Nesse período, Cabral não apenas se preocupava com as questões estéticas, mas também se voltava às ideológicas, adentrando no marxismo. Em 1948, planejava uma obra comprometida: “(...) uma espécie de explicação de minha adesão ao comunismo. Como essa palavra é explosiva, chamarei a coisa, plagiando o José de Alencar: Como e por que sou romancista." ${ }^{80}$ No entanto, impactado com a notícia de que a expectativa de vida no Recife era de 27 anos, iniciou $O$ cão sem plumas, primeira obra em que focalizava a situação precária do homem de sua região: "Ando com muita preguiça e lentidão trabalhando num poema sobre o nosso Capibaribe. A coisa é lenta porque estou tentando cortar com ela muitas amarras com minha passada literatura gagá e torre-de-marfim." ${ }^{81}$ Nas conversas com Brossa, que em 1950 receberia um exemplar de 0 cão sem plumas ${ }^{82}$, defendia um compromisso social na obra de arte, que deveria ser de "revolta", e não de "revolução" como ditava o realismo socialista, pois, caso contrário, seriam "destruídos" pela a ditadura. Portanto, poderia continuar escrevendo poemas de orientação surrealista, porém oferecendo uma direção, um sinal ao leitor. ${ }^{83}$

Em 1951, Cabral ocupava seu novo posto em Londres, mas continuou mantendo contato com Brossa, cujos poemas registram o conteúdo das cartas enviadas pelo brasileiro. No poema "Antoni Tàpies", de Coral (1951), datado de "1V-1951", menciona uma carta: "(...) Temos de mudar - me/ escreve Cabral -, temos

\footnotetext{
${ }^{78}$ Idem, ibidem, p. 235.

${ }^{79} \mathrm{~V}$. Anexos.

${ }^{80}$ Carta a Carlos Drummond de Andrade de 9 de outubro de 1948 (SÜSSEKIND, Flora, org. Op. cit., p. 228).

81 Carta a Manuel Bandeira de 3 de dezembro de 1949 (Idem, ibidem, p. 114).

82 V. Anexos, Dedicatórias autógrafas em livros.

${ }^{83}$ PERMANYER, Lluís. Brossa x Brossa. Records. Barcelona: Edicions La Campana, 1999, p. 88. V. depoimento de Brossa em Cadernos de Literatura Brasileira. n. 1. João Cabral de Melo Neto. Instituto Moreira Salles, São Paulo, março de 1996, p. 16-17.
} 
de ter a certeza/ que nos mudamos de casa. Este é o primeiro passo." ${ }^{84}$ Em "Tots en el crit” (Todos no grito), da mesma coletânea, retoma mais uma carta:
(...) Hoje
tive notícias de Londres, de Cabral, e com a carta alvejarei este establo desde a porta até o último recanto: Nós
Depois de saber o que nasce, somente
os suicidas podem preferir o gemido e a ruptura.
O nosso amigo
também procura a todo custo a grande nação do amanhã.
A árvore secreta dos velhos dias não está no nosso céu.
Ele, de Londres, compõe uma alta estátua verde com
plumagem de alento:
homem, mulher, trigo, vinho, pão, figuras do povo. ${ }^{85}$

temos que compreender - me escreve - o que há de moribundo e de novo

[no mundo atual

Cabral enviava livros para que Brossa pudesse encontrar exemplos para redirecionar sua obra. Um deles, anunciado em carta de 16 de maio de $1951^{86}$, foi Poèmes de Nazim Hikmet, que se conserva na biblioteca particular do poeta catalão. ${ }^{87}$ No prefácio, assinado por Tristan Tzara, Brossa destacou a lápis a seguinte passagem: “(...) Nesse sentido, a poesia de Nazim pertence ao domínio cultural do homem de hoje e, pela amplitude de sua autenticidade histórica, ela possui o valor de uma verdade permanente." Os versos do turco Nazim Hikmet, com referências à história e cultura de seu país, serviram mais de uma vez a Brossa de epígrafe, como a do já citado Coral, "Jo vaig amb la claredat que avança...", primeiro verso do poema "Voilá", à página 136 da edição presenteada por Cabral ("Je suis dans la clarté qui s'avance").

A partir desse rico intercâmbio, surgiu a coletânea En va fer Joan Brossa (1951), "os primeiros passos do autor no sentido de realizar uma poesia mais amplamentemente humana", nas palavras do prólogo de Cabral, no qual expõe pela

\footnotetext{
${ }^{84}$ (...) Hem de canviar - m'ha/ escrit Cabral-, hem de tenir la certesa/ que ens cal canviar. Aquest és el pimer pas. (BROSSA, Joan. Op. cit., p. 317).

${ }^{85}$ Avui/ he tingut notícies de Londres,/ d'en Cabral, i amb la carta emblanquinaré aquest estable,/ des de la porta fins a l'ultim racó: Nosaltres/ hem de comprendre - m'escriu - el que hi ha de moribund i de nou al món actual./ Després de saber el que neix, només/ els suïcides poden preferir el gemec i la ruptura./ El nostre amic/ també busca a cada roca la gran nació del demà,/ L'arbre secret dels vells dies no és al cel nostre./ Ell, des de Londres, entreteixeix una alta estàtua verda amb/ plómatge d'ales:/ home, dona, blat, vi, terra, pa, figures del poble. (Idem, ibidem, p. 311)

${ }^{86}$ Fundació Joan Brossa - Barcelona.

${ }^{87}$ Paris: Les editeurs français réunis, 1951 (Fundação Vila Casals - Barcelona).
} 
primeira vez sua nova concepção de poesia. Segundo ele, a superação do formalismo da arte estaria na retomada do tema dos homens. No caso de Brossa, em lugar de encontrar uma forma "realista", como muitos experimentavam naquele momento, estava seguindo o caminho oposto ao fazer poemas que levassem em conta seu repertório de elementos cotidianos e populares.

Cabral já não mais apóia incondicionalmente Carles Riba e os poetas da geração da revista Ariel, contrapondo-os a Brossa: enquanto aquela poesia preocupava-se com o "vocábulo nobre, pouco corrente, erudito ou arcaico", o autor de Sonets de Caruixa buscava o material para sua obra "na realidade mais humilde, no léxico da cozinha, da feira de praça e de fundo de oficina". Dessa maneira, com o objetivo de "comunicar-se com os outros homens", escreveu os poemas esquemáticos e prosaicos de Em va fer Joan Brossa.

Mais tarde, incluiu em Paisagens com figuras o poema "Fábula de Joan Brossa", que de certa forma recupera as idéias do prefácio a Em va fer Joan Brossa:

Joan Brossa, poeta frugal, que só come tomate e pão, que sobre papel de estiva compõe versos a carvão, Nas feiras de Barcelona, Joan Brossa, poeta buscão, as sete caras do dado, as cinco patas do cão antes buscava, Joan Brossa, místico da aberração, buscava encontrar nas feiras sua poética sem-razão. Mas porém como buscava onde é o sol mais temporão, pelo Clot. Hospitalet, onde as vidas de artesão, por bairros onde as semanas sobram da vara do pão e o horário é mais comprido que fio de tecelão, acabou vendo, Joan Brossa, que os verbos do catalão tinham coisas por detrás eram só palavras, não. Agora os olhos, Joan Brossa (sua trocada instalação), voltou às coisas espessas que a gravidez pesa ao chão e escreveu um Dragãozinho denso, de copa e fogão, 
que combate as mercearias

com ênfase de dragão. (SA, 124-125)

Como em "Fábula de Rafael Alberti", apresenta-se a trajetória de um poeta, que parte da experiência surrealista - "poética sem-razão" - para a conquista de uma poesia com mais referências empíricas. Em um primeiro momento, Brossa procurou a fonte de sua obra no variado e popular mundo das feiras, resultando, por exemplo, em Romancets del Dragolí (Romances do Dragãozinho), escrita em 1948. Porém, em seu itinerário chegou aos bairros dos artesãos, onde não se estimula a imaginação e os sentidos, mas se assiste ao trabalho demorado e às dificuldades cotidianas. A partir desse encontro, muda a concepção da linguagem, de "só palavras" a "coisas", o "caminho inverso" de "Fábula de Rafael Alberti". Aliás, este poema e "Fábula de Joan Brossa", além de se aproximarem no título, compartilham a imagem da palavra como coisa, cujo peso a impele ao "chão". Em lugar de mencionar Em va fer Joan Brossa, no qual definitivamente se reflete a nova etapa, Cabral prefere retomar o emblemático Dragãozinho, como se ele também tivesse se transformado, ao se mostrar mais prosaico e combativo.

\section{0 rio e seus afluentes: a poesia medieval espanhola}

Cabral em $O$ cão sem plumas iniciou a recuperação da tradição do nacionalismo ou regionalismo do Modernismo brasileiro das décadas de 20 e 30, passando a valorizar os autores de assunto "brasileiro" frente aos de assunto "universal", como explica em carta de 11 de dezembro de 1951 a Bandeira:

Hoje eu compreendo melhor como para qualquer artista brasileiro deixar de ser brasileiro para ser "universal" significa empobrecimento. Depois de alguns anos na Europa pude verificar o desinteresse que o europeu - i.e., o leitor universal experimenta diante de nossos autores universais: Lúcio Cardoso, Cecília Meireles, Schmidt, etc. (estou dizendo isso em segredo). E ao mesmo tempo o entusiasmo que certos autores mais brasileiros (M. Bandeira, M. de Andrade, etc.), apesar de difíceis, despertam. Essa foi uma experiência que nos ajudou muito a compreender muitas 
coisas. E posso garantir que não era o gosto do exótico que determinava o interesse de que estou falando. ${ }^{88}$

De volta ao Brasil em 1952, envolveu-se com o meio literário por meio de depoimentos, palestras e artigos para a imprensa, divulgando os princípios de sua poética. Uma das mais importantes intervenções ocorreu em 13 de novembro desse ano, a conferência "Poesia e composição - A inspiração e o trabalho de arte", na Biblioteca Municipal de São Paulo. Se há pouco tempo defendia o "tema dos homens" na base das experiências de vanguarda, nesse momento reivindicava uma linguagem mais comunicativa, inquietação que, como foi visto, o perseguia desde o começo de sua obra. Propõe, entre outros, o exemplo da literatura espanhola, ao integrar o trabalho individual do artista e o legado coletivo: "(...) Como na poesia popular, funde-se o que é de um autor e o que ele encontrou em alguma parte. A criação inegavelmente é individual e dificilmente poderia ser coletiva. Mas é individual como Lope de Vega escrevendo seu teatro e seu 'romancero', de aldeia em aldeia de Espanha, em viagem com seus comediantes e profundamente identificado com seu público." (P, 69). Em mais de uma entrevista considerava a literatura espanhola a "maior do mundo", interpretada como "realista", "popular", "objetiva" e "concreta", noções comuns a uma tradição crítica da literatura espanhola vinda do século XIX. Embora desde sua chegada à Espanha em 1947 tenha percorrido uma história literária, isso não o impediu de estabelecer escolhas de acordo com a poética que vinha elaborando:

(...) prefiro aqueles momentos em que a literatura espanhola é realista e objetiva e tenho menos interesse pelos momentos em que ela tende para 0 universo e o subjetivo. Assim, prefiro a épica primitiva, o 'romancero', a novela picaresca, etc., e me interesso menos pelo neo-classicismo, pela mística, pelo romantismo, etc. Modernamente, em poesia, prefiro a fase que vem de Antonio Machado até Miguel Hernandez e dou menos importância à poesia metafísica que foi posta em moda pelo atual regime político. ${ }^{89}$

\footnotetext{
${ }^{88}$ SÜSSEKIND, Flora, org. Op. cit., p. 146.

${ }^{89}$ Entrevista de 1953 (MAMEDE, Zila. Op. cit., p. 132).
} 
Dedicou a Hernández o poema "Encontro com um poeta", de Paisagens com figuras. De origem humilde, lutou na Guerra Civil Espanhola, defendendo os ideais da Espanha republicana. Condenado como "poeta da revolução", morreu na prisão em 1942. Por outro lado, Cabral rejeitou os poetas "oficiais", da Espanha vencendora, reunidos em torno das revistas Escorial (1940) e Garcilaso (1943), como Luis Felipe Vivanco, Leopoldo Panero e Luis Rosales. Ao pedir a Vinicius de Moraes a colaboração com uma obra para sua prensa manual, em 16 de novembro de 1947, mencionou essa corrente: “(...) Espero que seu 'sim' me impedirá de dedicar a coleção 'inconsútil' aos milhares de poetas em Cristo que há em minha geração brasileira (na Espanha também: os poetas de minha geração aqui ou são do discurso metafísico ou do soneto garcilaseano; ou, o que é mais comum, das duas coisas, simultaneamente;(...)"90

A seleção da poesia espanhola realizada por Cabral, segundo ele próprio, poderia oferecer novos rumos para a poesia brasileira, particularmente a Geração de 45, distante dos temas sociais e às voltas apenas com a forma em si: "Hoje, acho que a nossa poesia deve se orientar para as baladas, para os romances. A técnica poética, quando não é aplicada a alguma coisa, põe o poeta em um beco sem saída." ${ }^{91}$ A respeito desse movimento, publicou uma série de 4 artigos para o Diário Carioca em 1952, nos quais valoriza as conquistas da poesia das décadas de 20 e 30, fundadas no "vocábulo prosaico ou pela imagem prosaica": "Na verdade, as possibilidades do terreno aberto pelo Modernismo longe estão de esgotadas." ( $P, 73)$

Porém, o "vocábulo prosaico e imagem prosaica" ainda não surgem totalmente em $O$ cão sem plumas, não satisfazendo os novos parâmetros do poeta: "É o Capibaribe visto de fora. A existência do assunto é clara. Evidentemente a linguagem ainda é cifrada. A verdade é que naquela época eu não me tinha libertado ainda do preconceito de que poesia é a transplantação metafórica da realidade." ${ }^{.92} \mathrm{Em}$ 1954, retornou ao mesmo Capibaribe com a publicação d'O rio, só

\footnotetext{
${ }^{90}$ Arquivo Vinicius de Moraes, Arquivo-Museu de Literatura Brasileira, Fundação Casa Rui Barbosa. Em carta a Manuel Bandeira de 4 de agosto de 1950, Cabral comenta seu desagrado com a poesia espanhola da época: "A poesia espanhola pós-franquista é profundamente reacionária: é em Cristo, metafísica, enfim, profundamente subjetiva. Coisa que aliás confirma aquela coisa de Goethe, de que o subjetivismo é o próprio das épocas reacionárias." (SÜSSEKIND, Flora, org. Op. cit., p. 124-125).

${ }^{91}$ Entrevista de 1952. (MAMEDE, Zila, Op. cit., p. 131).

92 Entrevista a Vinicius de Moraes em 27 de junho de 1953. (MAMEDE, Zila. Op. cit., p. 131). Haroldo de Campos considera $O$ cão sem plumas "como estágio de trânsito entre ambas as diccções do poeta, um momento de equilíbrio estável entre as conquistas construtivas de $\mathrm{O}$ Engenheiro e da
} 
que não mais por meio de uma linguagem "cifrada", mas a partir de procedimentos formais mais comunicativos, buscados na primitiva poesia espanhola, marcada pela oralidade, canto para um público, como a épica e o romancero.

O Poema de Mio Cid, a poesia épica fundadora da literatura espanhola, tornou-se decisivo para que Cabral não apenas empreendesse o "tema dos homens", mas principalmente encontrasse uma forma adequada para expressá-lo. Em uma entrevista explicou a descoberta:

Quando fui para a Espanha, não tinha conhecimento da antiga literatura brasileira, e continuo sem ter. Mas estudei a velha literatura ibérica para compensar essa falta de back-ground cultural. Comecei a estudá-la - sou um leitor doentio pelo poema do Cid. Fiquei no ouvido com o ritmo desse poema, que é o mesmo de $O$ rio. Ritmo áspero, de coisa grosseira, mal acabada. Existe na Espanha um verso chamado de arte maior, com a primeira parte variável e a segunda fixa. Em O rio fiz o contrário: a primeira parte, a dos versos ímpares, é fixa, todos têm seis sílabas. Os versos pares podem ser qualquer número silábico. Isso cria um ritmo. ${ }^{93}$

Some-se ao ritmo a incorporação da rima toante, presente, como observou o próprio Cabral, em alguns poemas de Cecilia Meireles: "A rima toante é uma tradição muito antiga, abandonada em Portugal. Era uma tradição de toda Península Ibérica e dela se encontram vestígios na poesia popular do Nordeste brasileiro que a recebeu antes de Portugal ter-se descartado dela." 94

Ao lado das sugestões formais, o Poema de Mio Cid contribuiu também com imagens e situações. Tanto n'O rio - que também se intitula Relação da viagem que faz o Capibaribe de sua nascente à cidade do Recife -, quanto em Morte e vida Severina, a narração acompanha a viagem dos retirantes, que abandonam sua terra natal por causa da seca e da miséria, em busca de uma vida melhor no litoral. Por sua vez, a descrição de viagens e marchas é comum nas canções épicas: Rodrigo

Psicologia e a vontade de comunicação, de abertura do âmbito semântico do poema." ("O geômetra engajado" In Metalinguagem \& outras metas. 4a edição. São Paulo: Editora Perspectiva, 1992., p. 84).

${ }_{93}$ Entrevista a Antonio Carlos Secchin (SECCHIN, Antonio Carlos. João Cabral: a poesia do menos. São Paulo: Duas Cidades; Brasília: INL, 1985, p. 303).

${ }_{94}$ Entrevista em Jornal do Brasil, Rio de Janeiro, 3 de maio de 1980. 
Diaz de Vivar é desterrado de Castela pelo rei Alfonso VI, percorrendo terras e lutando contra os mouros.

Além do Poema de Mio Cid, há mais uma forte presença da poesia medieval espanhola n'O rio. Gonzalo de Berceo, clérigo do século XIII e autor de obras religiosas como os Milagros de nuestra señora, forneceu a epígrafe: "Quiero que compongamos io e tú una prosa". O verso foi retirado de um dos escritos dedicados à Virgem Maria, Aqui escomienza el duelo que fizo la Virgen Maria el dia de la pasion de su fijo Jesu Christo; mais especificamente, encerra a estrofe em que a Virgem atende às súplicas do monge Sant Bernalt por conhecer os sofrimentos dela:

Fraire - disso la Duenna - non dubdes en la cosa; yo só Donna Maria, de Josep la esposa, el tu ruego me trae apriessa e cueitosa; quiero que compongamos yo e tu una prossa. ${ }^{95}$

Berceo, primeiro poeta conhecido da literatura espanhola, provavelmente em apresentações orais, procurava ensinar e doutrinar o povo na matéria religiosa. A vontade da Virgem Maria em fazer Sant Bernal, espécie de representação do ouvinte, "participar" de seu relato da crucificação e ressurreição de Jesus Cristo, expressaria a tentativa de Berceo em envolver seu público para que juntos acompanhassem uma "prosa". Essa palavra, originária do latim, significa "o que anda em linha reta"; daí a oposição entre texto em prosa ou em verso. Seu uso por Berceo - aliás, o primeiro documento em castelhano - para se referir a um texto em verso, pressupunha a "seqüência" que se dizia em certas missas, e posteriormente, composição poética de caráter religioso. No poema de Cabral, podem confluir os sentidos primitivos e atuais de prosa: a "seqüência" ou "relação" do rio revela um mundo "prosaico", de pobreza e luta pela sobrevivência.

Para transmitir sua mensagem de forma eficaz, Berceo vale-se de uma linguagem corrente, não erudita, como adverte em La vida de Santo Domingo de Silos:

\footnotetext{
${ }^{95}$ BERCEO, Gonzalo de. Signos que aparecerán antes del Juicio final. Duelo de la Virgen. Martirios de San Lorenzo. Edição de Arturo M. Romoneda. Madri: Castalia, 1980, p. 166.
} 
Quiero fer una prosa en qual suele el pueblo ca non so tan letrado bien valdrá, como creo, en román paladino,

fablar con so vecino, por fer otro latino; un vaso de bon vino. ${ }^{96}$

Um dos recursos mais utilizados por Berceo é a comparação, geralmente a partir de elementos concretos, comuns, para facilitar a compreensão da distante esfera religiosa, tornando-a visível. ${ }^{97}$ Os animais, por exemplo, estão muito presentes nessas comparações, principalmente o cachorro. Cabral, que tornou a comparação uma estrutura recorrente em sua obra, já aproximara o mesmo Capibaribe a um cão. Portanto, Berceo seria para Cabral o grande exemplo de como um homem de cultura pode se comunicar com seu público. Os objetivos são opostos: o "mester de clerecía" queria catequisá-lo, já o poeta do século XX, denunciar-Ihe uma situação social.

No poema "Catecismo de Berceo", de Museu de tudo, Cabral, longe de se preocupar com os princípios religiosos do clérigo medieval, discorre pelo legado de um estilo espanhol fundado em um vocábulo "concreto", já proposto nos poemas "Fábula de Rafael Alberti" e "Fábula de Joan Brossa":

1.

Fazer com que a palavra leve pese como a coisa que diga, para o que isolá-la de entre o folhudo em que se perdia.

2.

Fazer com que a palavra frouxa ao corpo de sua coisa adira:

\footnotetext{
${ }^{96}$ BERCEO, Gonzalo de. La vida de Santo Domingo de Silos. Edição de Brian Dutton. Londres: Tamesis Books, 1978, p. 35.

97 Joaquín Artiles atribui o ambiente campesino que cerca o clérigo como inspirador desse processo: “(...) Inmerso en el mundo de la Rioja, afloran en sus versos, como soporte comparativo, ese montón de cosas que son el campo y el hogar, la casa y la intemperie. Berceo, que nunca se olvida de sus oyentes, trata de hacer llegar hasta ellos, por obra y gracia de lo concreto y cercano, otras realidades más lejanas y elevadas. Sus comparaciones (y lo mismo diríamos del mundo de sus imágenes) tienen, por eso, un caráter descendente, de rebajamiento, de acercamiento a lo inmediato y cotidiano. Berceo quiere, con buen sentido pedagógico, que sus oyentes se eleven y asciendan a la compreensión de realidades superiores por la fácil escala de las cosas más familiares." (Los recursos literarios de Berceo. Madri: Gredos, 1964, p. 124-125.)
} 
fundi-la em coisa, espessa, sólida,

capaz de chocar com a contígua.

3.

Não deixar que saliente fale:

sim, obrigá-la à disciplina

de proferir a fala anônima,

comum a todas de uma linha.

4.

Nem deixar que palavra flua

como rio que cresce sempre:

canalizar a água sem fim

noutras paralelas, latente. (EPD, 59-60)

A imagem da canalização da água em paralelas reflete o rigor do clérigo ao utilizar a "cuaderna vía", estrofe de quatro versos de 14 sílabas, com pausa ou cesura no meio. Na página escrita ou impressa, a sinuosidade do espaço em branco das pausas lembra o curso de um rio "canalizado" pelos heptassílabos. O objetivo de proferir a "fala anônima" poderia ser acompanhado com a "disciplina" na construção do poema.

\section{Traduções: Ángel Crespo e Gabino-Alejandro Carriedo}

Por volta de 1960, quando ocupava o cargo de primeiro secretário da Embaixada brasileira em Madri, Cabral estabeleceu amizade com os poetas Ángel Crespo (1926-1995) e Gabino-Alejandro Carriedo (1923-1981), os quais se tornaram tradutores tanto da obra dele ${ }^{98}$, quanto de outros poetas brasileiros, principalmente nas páginas da Revista de Cultura Brasileña. Além de estimularem as relações literárias entre Brasil e Espanha, os três poetas mantiveram um importante diálogo a partir de suas obras.

\footnotetext{
${ }^{98}$ V. Anexos, Traduções de poemas de João Cabral de Melo Neto na Espanha.
} 
Carriedo e Crespo, em 1945, formaram parte do grupo de vanguarda denominado Postismo, o qual se promovia como sucessor dos movimentos das décadas de 20 e 30, como o surrealismo. Mais tarde, entre 1960 e 1963, dirigiram a revista Poesía de España, cujo suplemento "Poesía del mundo" ofereceu traduções e notas biobibiográficas de Drummond e Cabral, entre outros. Nesse momento, retomavam a tradição de uma poesia comprometida na Espanha, muitas vezes fundada na experiência da vida campesina. O Poema de la condenación de Castilla (1946), de Carriedo, é a primeira obra, depois da Guerra Civil, dedicada à terra e ao homem dessa região:
Castilla excomulgada, estéril, seca
como estatua de sal, como una madre
sin fértil alentar, sin el espasmo
doloroso y feliz de un parto nuevo
de extraña madurez y fallecida
ya en cada herida vieja, ya en el sordo
recuerdo aterrador, miseria y luto. ${ }^{99}$

A contundência das imagens assemelham-se ao universo castelhano e pernambucano de Paisagens com figuras, indicando como se identificaram as propostas poéticas de Cabral e Carriedo. Contudo, os dois poetas espanhóis criticavam a poesia social que vinha sendo realizada, apenas voltada ao conteúdo, sem maiores cuidados estéticos. No texto "Poética", incluído na antologia Poesía social (1965), organizada por Leopoldo Luís, Crespo esclarece seu ponto de vista:

¿Cómo puede facilitarse un cambio de las circunstancias sociales con una técnica conformista? En nuestra poesía "social" hay mucho 98, no hay investigaciones formales serias y actualizadas, sistemáticas. Si las nobles ideas que animan esta poesía son ciertamente universales, lo primero que se impone es una apertura al universo mundo de la poesía, enlazar con él y tomar lección de sus conquistas o, más sencillamente, de su afán renovador. Se ha tenido en cuenta lo que se dice pero no la manera de expresarlo. Con ello, se ha empobrecido el

\footnotetext{
${ }^{99}$ Apud LECHNER, J. El compromiso en la poesía española del siglo XX. Alicante: Publicaciones de la Universidad de Alicante, 2004, p. 581.
} 
lenguaje y, así, se ha producido esa crisis de expresión que ha conducido a la no menos triste de valores, que también padecemos. ${ }^{100}$

Carriedo, em depoimento para a mesma antologia, defende a conciliação entre os movimentos "pós-vanguardistas" e a poesia social. ${ }^{101} \mathrm{~A}$ união entre estética e comprometimento, ou vanguarda e comprometimento, denominam Crespo e Carriedo de poesia "realista", considerando a obra cabralina como uma importante referência. Aliás, a noção "realista", sem a conotação estrita do termo, foi utilizada por Crespo no importante estudo Realidad y forma en la poesía de Cabral de Melo (1964): “(...) sin renunciar a la investigación de la realidad, antes bien procurándola afanosamente, se muestra a la vez como ejemplo de exigencia estética a través de una forma equilibrada y racional y en ningún modo ajena a la experimentación."102

Em 1962, os dois poetas espanhóis recebiam de Cabral Terceira feira ${ }^{103}$, publicado no ano anterior e que reunia as três últimas coletâneas. Em Quaderna, por exemplo, consolidou os poemas dedicados à Espanha e ao Nordeste - iniciados em Paisagens com figuras - que se entrelaçam no "Poema(s) cabra". No aparte final à série de 9 poemas, contrasta "duas paisagens", as "terras nobres" das margens do Mediterrâneo e a "piçarra" do Sertão, mas que podem ser aproximadas pela cabra que habita as duas regiões: "Mas não minto o Mediterrâneo/ nem sua atmosfera maior/ descrevendo-Ihe as cabras negras/ em termos das do Moxotó." (EPD, 245). A comparação vale-se do concreto, do prosaico, mais especificamente com o animal: se antes o cotejo era entre cão/ rio/ homem, passou a ser entre cabra/ homem. Conseqüentemente, a descrição da difícil condição de vida e da resistência da cabra remete-nos também ao ser humano. Logo no primeiro poema, a cor negra sugere uma situação de exclusão de uma etnia, familiar à sociedade brasileira: "O negro da cabra é o negro/ do preto, do pobre, do pouco. (...) "É o negro da segunda classe,/ Do inferior (que é sempre opaco)." (EPD, 239-240). Do mesmo modo que a cabra aprendeu a sobreviver em um meio inóspito, o homem seguiu seu modelo: "O nordestino, convivendo-a,/ fez-se de sua mesma casta." (Poema 8, EPD, 244); "A

\footnotetext{
${ }^{100}$ Apud CRESPO, Ángel. Antología poética. Edição de Arturo Ramoneda. Madri: Alianza Editorial, 1994, p. 17.

${ }^{101}$ Apud, LECHNER, J. Op. cit., p. 673.

102 CRESPO, Ángel e BEDATE, Pilar Gómez. Realidad y forma en la poesía de Cabral de Melo. Separata da Revista de Cultura Brasileña. n. 8, Madri, março 1964, p. 6.

${ }^{103}$ V. Anexos, Dedicatórias autógrafas em livros.
} 
cabra deu ao nordestino/ esse esqueleto mais de dentro:/ o aço do osso, que resiste/ quando o osso perde seu cimento." (Poema 9, EPD, 244).

Crespo interessou-se pelo "Poema(s) da cabra" ao traduzir, em 1963, os três primeiros na história literária que vinha apresentando na seção "Aspectos de la cultura brasileña" do periódico Brasil, do Serviço de Propaganda e Expressão Comercial da Embaixada brasileira em Madri. ${ }^{104}$ Por sua vez, também dera lugar a "La cabra", poema publicado em edição de bibliófilo em 1962:

La vieja cabra que el cuchillo

respetó. Se movía

como la hierba cuando crece.

De pronto, sus orejas

ya estaban lacias, o su belfo

entreabierto, o estaba

el animal junto a la puerta

del horno. El animal

- o más bien bicho, fardo

de piel y huesos, con las ubres

como viejas talegas que guardaron

cobre y, a veces, plata-,

el bicho melancólico

que se dormía al sol tocando tierra

con los hermosos cuernos.

Porque los cuernos eran su sonrisa,

su afirmación, su gesto de haber sido:

brillantes de mañana, por la siesta

mates de polvo y tedio, por la noche

oscuros de abandono, y humeantes

de bruma con la aurora.

Vieja herencia

de algún día que el hambre se olvidó

de olisquear el filo del cuchillo,

de lamer el barreño en que la sangre

se cuaja, de mover

$\overline{104}$ a. 3, n. 10-11-12, Madri, out./dez. 1963. 
la artesa que presencia el sacrificio;

vieja cabra, durando

como la duración, como las hierbas

que cuelgan del tejado,

como la voz idéntica que llama

desde el fondo del patio cada día,

como el tiempo que aprieta los costados,

se va después, jadea

$\mathrm{y}$, cuando va a morir, clava los cuernos

en el contemplado desprevenido. ${ }^{105}$

Diante da decrepitude da velhice, o único que resta de belo e digno na cabra são os seus cornos, "seu gesto de ter sido". No entanto, o que parecia apenas objeto de contemplação, no instante da morte, desperta em uma última reação. No "Poema(s) da cabra" não são os cornos, mas justamente a cor negra que ocupa os três primeiros poemas traduzidos por Crespo. No terceiro, refere-se à "alma córnea", imagem que concretiza, a partir de seu principal atributo, a força "interior" da cabra. O nordestino, da "mesma casta", possui o "aço do osso". Quanto a "La cabra", essa "alma córnea" não a abandona mesmo na hora do sacrifício.

Carriedo deixou traços mais explícitos da obra cabralina em sua poesia. Antonio Martinez Sarrión, no prólogo ao Nuevo compuesto descompuesto viejo (Poesía 1948-1978), assinalou a presença marcante do brasileiro:

Sobre todos los poetas de expresión portuguesa, le influye poderosamente la voz del gran João Cabral de Melo Neto (....) la inteligente simbiosis de postsimbolismo y realismo, unida a su obsesión por las posibilidades aleatorias del poema, concebido dentro de cánones casi matemáticos de puro económicos y esenciales, hacen de la poesía cabralina una experiencia única, sin nada que ver con cualquier tendencia de la poesía española de las últimas décadas.

Pues bien, la influencia, no única, mas predominante del brasileño, se unió en Carriedo, por afición y dedicación profesional (...). ${ }^{106}$

\footnotetext{
${ }^{105}$ CRESPO, Ángel. Libro cuarto (1958-1964) In En el medio del camino (1949-1970) In Poesía. v. 1. Edição de Pilar Gomez Bedate e Antonio Piedra. Valladolid: Fundación Jorge Guillén, 1996, p. 189190.

${ }^{106}$ CARRIEDO, Gabino-Alejandro. Nuevo compuesto descompuesto viejo (Poesía 1948-1978). Madri: Peralta, 1980, p. 19.
} 
Escolheu como epígrafe ao poema "Teoría de la minería", de El corazón en el puño (1961), os versos "que é a morte de que se morre/ de velhice antes dos trinta" de Morte e vida Severina, traduzido por ele e Crespo em 1966. Trata-se de uma pungente visão do árduo trabalho dos mineiros; assim como a miséria do Nordeste brasileiro, conduz à morte: "Cien mil familias crecen a la sombra,/ mas todos mueren a los treinta." 107

Posteriormente, seguiu em alguns poemas a estrutura binária de $A$ educação pela pedra - no qual the é dedicado "Rios sem discursos" -, aproximando-se muito do estilo cabralino. Em "Cuenca y sus hoces", além de reunir as significativas imagens da pedra e do rio - presentes no título do estudo de Lauro Escorel de 1973 -, pratica a assonância nos versos ímpares: "Para entender la escultura hay que hablar/ un lenguaje de piedra entre dos ríos;/ no basta la cultura de lo estudiado/ si falla el conocimiento de lo vivido."108

Mas o compromentimento não foi abandonado, como verificamos nos dois poemas que denunciam a poluição dos rios madrilenhos:

\section{Los ríos de Madrid}

Los ríos de Madrid son ríos raquíticos de albúmia y petroleo, ríos por dentro, pero arroyos cuando sobre la superficie apenas se desplaza su líquido esqueleto. Los ríos de Madrid no son más que cloacas con numerosos puntos de desagüe; cursos pequeños de aguas negras que es igual que decir aguas fecales. Por eso son los ríos de Madrid no existentes: ríos para cantados mas con benevolencia el cercano Jarama, ocre de tierra y grava, y el Manzanares, que apenas agua lleva.

\section{2}

Pero no para cantados con sentido crítico: los ríos de Madrid son un cuadro mal hecho, un proyecto de ingeniero sin experencia o un poema que no llega a soneto.

Por eso son, los ríos, granos moleculares y es su agua gorda y espesa como limo,

\footnotetext{
107 Idem, ibidem, p. 99-100.

${ }^{108}$ Idem, ibidem, p. 179.
} 
mas llena de organismos vivos que son los que hacen que las aguas se mueran, aunque con paso mínimo. ${ }^{109}$

De nuevo los ríos de Madrid

Si los ríos de Madrid son sólo gránulos de todo material en su seno prolíficio, las orillas de los ríos son vertederos donde se vuelcan a diario los detritus. No conocen el murmullo del agua ni en su curso-vida han visto lo verde; no son espejo de nada y en su seno jamás han quebrado su rumbo peces.

\section{2}

Por eso no figuran en todos los mapas los ríos de Madrid, de grasa y cieno; se les suprime como no existentes en la toponimia de lo madrileño.

O no se les suprime y entonces son vehículo el Jarama de sus gravas y tierras ocres - color pardo del pájaro -, y el Manzanares de sus aguas féditas.

De ahí que estos ríos sifilíticos apenas conozcan a los médicos: ríos de pus de herida infectada, ríos enfermedad y no ríos remedio. ${ }^{110}$

No segundo poema, a contraposição "não conhecem a vida" e " conhecem o doentio", prossegue o curso d'O cão sem plumas:
Aquele rio
era como um cão sem plumas.
Nada sabia da chuva azul,
da fonte cor-de-rosa,
da água do copo de água,
da água do cântaro,
dos peixes de água,
da brisa na água.

\footnotetext{
${ }^{109}$ Idem, ibidem,p. 183.

${ }^{110}$ Idem, ibidem, p. 187.
} 


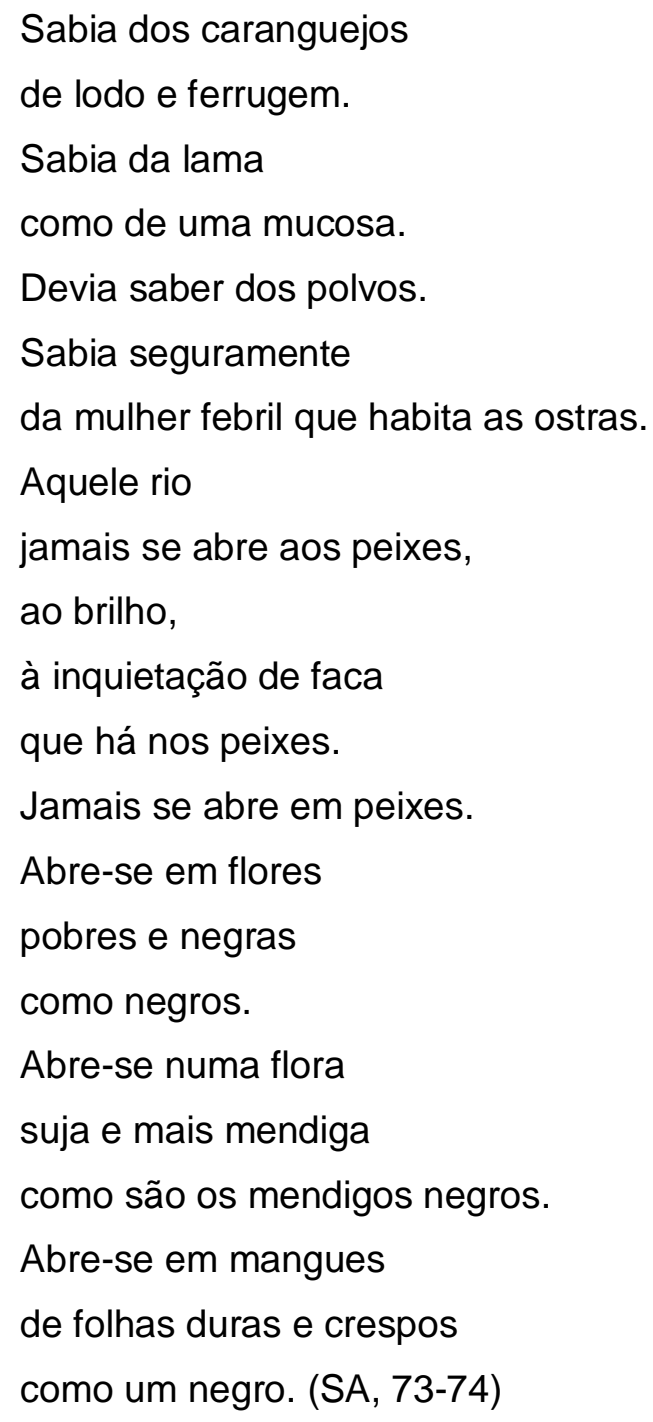

Carriedo dialogou com o primeiro poema de Cabral escrito na Espanha, entre 1949 e 1950, momento, como vimos, de fértil discussão, em Barcelona, de uma arte comprometida, sem perder de vista a envergadura estética. Sintomaticamente, na última estrofe citada d'O cão sem plumas, o poeta valeu-se dos mesmos "mangues crespos e de folhas duras" do monólogo de Joaquim d'Os três mal-amados, no qual se atormentava com aquilo que não sabia falar em verso. Pois na coletânea de 1950, a direta e prosaica comparação lança o poema na vida dos homens, a exemplo da tradição da literatura espanhola. Dessa forma, Cabral também pôde abrir caminhos para poetas tão distintos como o catalão Joan Brossa e o castelhano Gabino-Alejandro Carriedo. 


\section{CAPÍTULO 2: Leituras e leitores espanhóis de Murilo}

A biblioteca de Murilo Mendes, que hoje integra o acervo do Centro de Estudos dedicado ao poeta em Juiz de Fora, comporta muitos livros de literatura espanhola, especialmente poesia. Os títulos vão desde o Poema de Mio Cid até os poetas do século XX, o que revela a variedade dos interesses de Murilo, a "Espanha total, completa" assinalada por Cabral na carta de 1959, reunindo uma vertente "materialista" e outra "espiritualista". A junção dos contrários, um dos princípios da poética muriliana, poderia relacionar-se com uma constante de todos os tempos, como ele verificou na leitura da conferência "Escila y Caribdis de la literatura española", de 1927, na qual Dámaso Alonso discute a concepção a respeito dessa literatura que apenas reconhece as notas de realismo, popularidade e localismo. Em seu exemplar de Estudios y ensayos gongorinos, Murilo destacou a lápis a passagem em que o crítico defende a polaridade da literatura espanhola:

Goethe ha querido explicar la vida como un dualismo, como una oposición de contrarios en lucha, de fuerzas contrapuestas, pero unidas esencialmente en la entraña del principio vital. Esta ley de la polaridad creo que es la que define la esencia de la literatura española. Esta no se puede definir por la línea del popularismo-realismo-localismo, ni tampoco por de la selección-antirrealismouniversalidad. Estas dos direcciones serán sólo dos aspectos externos, contrapuestos y mutuamente condicionados de la misma fuerza esencial.

Nas linhas finais do texto, não marcadas por Murilo, conclui: "Este eterno dualismo dramático del alma española será también la ley de unidad de su literatura". ${ }^{111}$

Esse exemplo ilustra-nos que uma grande parte dos exemplares da biblioteca de Murilo recebeu anotações, como traços à margem, trechos sublinhados e uma relação dos temas relevantes e suas respectivas páginas na última folha de rosto. As anotações em um livro, processo comum a muitos leitores, no caso de um escritor, tornam-se um material valioso para compreender a recepção de uma obra e

\footnotetext{
${ }_{111}$ ALONSO, Dámaso. Estudios y ensayos gongorinos. Madrid, Gredos, 1955, p. 26-27.
} 
sua incorporação em seus próprios trabalhos. ${ }^{112}$ Dessa maneira, os livros anotados vinculam-se às obras Tempo espanhol e Espaço espanhol.

No entanto, antes das obras dedicadas à Espanha, Murilo teria iniciado uma incorporação da literatura espanhola, seguindo os conselhos de Cabral de que a poesia brasileira deveria promover as "baladas" e os "romances": em Contemplação de Ouro Preto (1954) inseriu os poemas "Romance das Igrejas de Minas", "Romance de Ouro Preto" e "Romance da Visitação". Sobre o Romanceiro da Inconfidência (1953), de Cecíla Meireles, também às voltas com Ouro Preto, Murilo comenta a vitalidade do romanceiro na literatura contemporânea:

O filão dos romanceiros é riquíssimo. Remontando a tão ilustre tradição, confundindo-se quase nas literaturas neolatinas com as bases da língua, o romanceiro tem sido explorado e renovado em nossos dias pelos poetas mais inquietos, de sensibilidade mais em consonância aos acontecimentos da nossa época, que enxertaram novas e mais vivas imagens no velho tronco austero, linear. E muitos dos romances antigos encontram nos fatos de agora uma súbita elucidação, quando tratados por poetas que possuem o duplo senso do clássico e do moderno. $^{113}$

No caso de Tempo espanhol, temos os 16 poemas - em um total de 65 - que compõem uma história da literatura espanhola, anunciada na série de epígrafes presentes na $1^{a}$ edição, que vai do Libro de Aleixandre a Miguel de Unamuno. ${ }^{114} \mathrm{O}$ primeiro deles, "Aos poetas antigos espanhóis", apresenta a poesia medieval tanto como paradigma de uma "linguagem concreta" e "seca", quanto de um conteúdo humano - "(O homem sempre em primeiro lugar)". Vale lembrar que em setembro de 1955, ano do início da produção de Tempo espanhol, Cabral ofereceu um

\footnotetext{
${ }^{112}$ No caso de Murilo, Raul Antelo explorou alguns aspectos das anotações dele em livros de autores hispânicos (Murilo Mendes lê em espanhol. I e II Congressos de literatura comparada da UFMG. Belo Horizonte: Imprensa Oficial, 1987, p. 537-554).

113 "Romanceiro da Inconfidência". Vanguarda, Rio de Janeiro, 1953. (MEIRELES, Cecilia. Obra poética. Rio de Janeiro: Editora Nova Aguilar, 1987, p. 53). Cecília, na crônica "Castilla la bien nombrada...", de 1953, relata parte de sua viagem à Espanha, entremeada por citações de romances, bases seguras do Romanceiro da Inconfidência: "E, enquanto o automóvel desliza por estas amarelas solidões, ponho-me a pensar se o ritmo de redondilha, que é o do Romancero, poderia medir igualmente o fragor das batalhas do Cid, como mede a sua narrativa. Ah! é que a vida cantada é outra coisa...." (MEIRELES, Cecilia. Crônicas de viagem, 2. Edição de Leodegário A. de Azevedo Filho. Rio de Janeiro: Nova Fronteira, 1999, p. 18).

${ }^{114}$ V. Anexos.
} 
exemplar d'O rio a Murilo ${ }^{115}$, anotado em mais de uma passagem. Como analisamos no primeiro capítulo, $O$ rio significou a síntese das lições da primitiva poesia espanhola, podendo ter sido, ao lado de Paisagens com figuras - divulgado em Duas águas em 1956 - uma das fortes referências de Murilo para Tempo espanhol.

No entanto, em posição oposta à de Cabral, o catolicismo de Murilo privilegiou os "santos escritores" Santa Teresa de Jesus e São João da Cruz. O fecundo "Siglo de Oro" contribui com o maior número de poemas, a respeito de Cervantes, Góngora, Lope de Vega, Tirso de Molina, Calderón e Quevedo. O século XX figura com os poetas vítimas do franquismo, Lorca e Miguel Hernández.

Além da tradição literária, no período de permanência na Europa, de 1957 a 1975, Murilo manteve um diálogo com importantes poetas espanhóis contemporâneos, os quais acompanharam tanto sua última produção poética Tempo espanhol e Convergência - quanto o conjunto de sua obra, reavaliada na sua primeira reunião em 1959: "Para esta edição revi inteiramente todos os textos, tendo também suprimido vários poemas que me pareceram supérfluos ou repetidos. Procurei obter um texto mais apurado, de acordo com a minha atual concepção da arte literária. Não sou meu sobrevivente, e sim meu contemporâneo." ${ }^{116}$ No artigo "A poesia e o nosso tempo", estampado no Suplemento Dominical do Jornal do Brasil, em 25 de julho desse ano, esclarece que a nova diretriz poética, marcada pela concisão e construção da linguagem, partia de um trabalho ao longo de sua obra: "Sendo de natureza impulsiva e romântica, cedo percebi que no plano da criação literária devia me impor um autocontrole e disciplina. Tendo em conta esta minha primeira natureza, julgo ter feito um trabalho de verdadeiro polimento de arestas, pois se os relacionar à minha contínua necessidade de expulsão, meus textos são até muito construídos e ordenados." ${ }^{117}$ Respondia assim a uma tradição crítica que apontava "defeitos" no aspecto formal, como por exemplo a resenha de Mário de Andrade sobre Poesia em pânico (1938), "livro mais de lirismo que arte":

(...) Ele se apresenta cheio de pequeas falhas técnicas, provando despreocupação pelo artesanato. (...) Os elementos de perfeição técnica, os encantos da beleza formal estão muito abandonados. O verso-livre é correto mas monótono, cortado exclusivamente pelas pausas das frases e das idéias. (...) O ritmo

\footnotetext{
${ }^{115} \mathrm{~V}$. Anexos, Dedicatórias autógrafas em livros.

${ }^{116}$ Poesias. 1925-1955. Rio de Janeiro: José Olympio, 1959.
} 
é bastante pobre, principalmente porque, pela altura do diapasão em que está, o poeta the deu um movimento muito uniforme, sempre rápido. Quem ler ou disser lentamente qualquer poesia do livro, Ihe destruirá o caráter. Às vezes há mesmo uma velocidade irrespirável. As frases não expiram: acabam. Mas novas frases lhes sucedem, montando umas nas outras, galopada tumultuária envolta numa polvadeira de gritos, imprecações, apóstrofes. E o movimento toma a contextura de um pranto convulsivo. Tudo isso é belo, vigorosíssimo, mas não há descansos, não há pousos, isto é, não há combinação. É uma criação espontânea, derivada de uma fatalidade psicológica, e não de uma intenção artística. ${ }^{118}$

A apreciação de Mário tornou-se uma espécie de paradigma para outras abordagens da poesia de Murilo, lembrada pelo próprio poeta em carta a Haroldo de Campos de 2 de maio de 1963:

(...) Certo é que manifestava-lhe minha satisfação pelo fato de um poeta do seu valor e da sua cultura reconhecer no autor de T.E. domínio estílístico, quando quase toda a crítica negava ou duvidava do fato (com única exceção talvez do $\mathrm{E}$. Portella, que o reconheceu ao escrever sobre as Poesias 1925-1955). A maioria apoiava-se no famoso artigo de Mário de Andrade sobre A Poesia em Pânico, esquecendo-se (ou fingindo ignorar) que em passagens posteriores o mesmo Mário escreveu coisas muito diversas a meu respeito. Enfim, seus artigos constituem o reconhecimento de um trabalho sério, aprofundado, não baseado apenas em impulsos líricos. Sou-lhe muito grato, e eu, que há 5 anos não escrevo versos, estou tentando recomeçar. ${ }^{119}$

O estudo referido intitula-se "Murilo e o Mundo Substantivo", originalmente divulgado no Suplemento literário de O Estado de São Paulo em janeiro desse ano. O crítico apresenta o livro como "termo de chegada num itinerário poético programaticamente caracterizado para demanda do mundo substantivo". ${ }^{120}$ A partir dessa constatação, recolhe muitos exemplos da ocorrência das palavras concreto e rigor e seus correlatos semânticos em Tempo espanhol, que "contém a diversificação léxica que ocorre em sua poesia anterior (de Poesia liberdade, por

\footnotetext{
${ }_{117}^{117}$ Catálogo da exposição Murilo Mendes: acervo. Juiz de Fora: UFJF/CEMM, 1999, p. 55.

${ }^{118}$ A poesia em pânico In $O$ empalhador de passarinho. $4^{\mathrm{a}}$ ed. Belo Horizonte: Editora Itatiaia, 2002, p. 53.

${ }_{119}$ GUIMARÃES, Julio Castañón, org. Op. cit., p. 137.

${ }^{120}$ Metalinguagem \& outras metas. $4^{a}$ ed. São Paulo: Editora Perspectiva, 1992, p. 69.
} 
exemplo) - certos procedimentos metafóricos dissonantes, de tipo surreal, como é óbvio, consomem um acervo muito maior de vocábulos imprevistos - e procura exercer a sua imagética de planos contrastantes, táctil-visual, dentro de uma linguagem voluntariamente reduzida". ${ }^{121}$ Quanto ao retorno à poesia, dava início à coletânea Convergência, que suscitou no Brasil, na esteira das observações de Haroldo de Campos, uma filiação de Murilo ao concretismo.

Porém, Murilo não acreditava exclusivamente no aspecto formal da poesia, como declarou no artigo citado "A poesia e o nosso tempo", e reiterado outras vezes: "Sou contra a idolatria da linguagem; de resto sou contra idolatria. Não creio, repito, no artesanato literário como fim: é precisamente uma técnica de comunicação."122

As tensões entre tradição e modernidade, humanismo e formalismo, na obra de Murilo, também eram comuns à poesia espanhola. Neste capítulo, estudaremos a relação do poeta brasileiro com duas gerações de poetas espanhóis: os da consagrada Geração de 27, especificamente Vicente Aleixadre, Dámaso Alonso, Jorge Guillén e Rafael Alberti; e os jovens poetas da segunda metade do século XX, Ángel Crespo e Gabino-Alejandro Carriedo.

\section{Entre os "mestres do passado" e do presente}

Entre 1957 e 1959, Murilo estabeleceu amizade, que prosseguiria até o ano da sua morte, em 1975, com os principais nomes da Geração de 27, que por sua vez estão entre os da lírica espanhola do século XX. Com idades próximas ${ }^{123}$, no final da década de 50 o brasileiro e os espanhóis já eram poetas maduros, que haviam começado a escrever nos efervescentes anos 20: Guillén, depois da edição definitiva de Cántico (1950), iniciava um novo ciclo poético, Clamor. Tiempo de historia, pelo volume Maremagnum (1957); Aleixandre com Historia del corazón (1954), inaugurava um segundo período de sua obra; Dámaso Alonso, em meio a seus densos estudos literários, publicava Hombre y Dios (1955); e Alberti, do seu exílio na Argentina, cantava a nostalgia em Balada y canciones del Paraná (1954).

\footnotetext{
${ }^{121}$ Idem, ibidem, p. 70.

122 Catálogo da exposição Murilo Mendes: acervo. Op. cit., p. 55.

${ }^{123}$ Guillén era o mais velho, nascido em 1893, enquanto Aleixandre e Alonso em 1898, Murilo em 1901 e Alberti em 1902.
} 
Tempo espanhol, por sua vez, figurava nas estantes de Guillén e Alberti ${ }^{124}$, teve dois poemas traduzidos por Dámaso em $1962^{125}$ e recebeu um comentário elogioso de Aleixandre: "...Usted levanta un verdadero monumento a esta tierra que se puede decir que Ud. conoce y ama como pocos." ${ }^{126}$

Murilo avaliava esses poetas, da mesma forma que o conjunto da literatura espanhola, como resultado da fusão de contrastes:

(...) consolidou-se sob um duplo signo cultural muito expressivo: o retorno a Góngora, poeta erudito por excelência; a redescoberta do "Romancero" e dos "Cancioneros" populares espanhóis. A nota erudita e a popular serão, pois, constantes dessa geração comparada por Dámaso Alonso à do Século de Ouro. Aqueles poetas fundiram na sua obra as duas grandes correntes da literatura espanhola: a castelhana e a andaluza. Representam as duas faces da Espanha, a mística e a terrena, ou por outra, a abstrata e a concreta. (PCP, 1224)

Juntamente com o romancero, Murilo também se entusiasmou com Góngora, tornando-se para ele uma grande referência na literatura espanhola em relação ao fazer poético: inseriu dois poemas - "Arco de Góngora" e "Lida de Góngora" - em Tempo espanhol, além de ter realizado uma leitura atenta da obra do poeta e sobre ele. $^{127}$

Em 1927, ano do terceiro centenário de morte de Luís de Góngora, o grupo de poetas que seria denominado por essa data reuniu-se para resgatar a obra do poeta do século XVII em conferências, edições e poemas, alçando-o à condição de "precursor" de uma modernidade literária, fundada na metáfora. A poesia espanhola buscava sua renovação proclamando, segundo os princípios da poesia pura, o valor absoluto da imagem e do artesanato poético. Nesse sentido, Murilo anotou amplamente a importante conferência de Lorca, "La imagen poética de Don Luís de Góngora":

\footnotetext{
${ }^{124} \mathrm{~V}$. Anexos, Dedicatórias autógrafas em livros.

${ }^{125} \mathrm{~V}$. Anexos, Traduções de poemas de Murilo Mendes na Espanha.

${ }_{127}^{126}$ Espaço espanhol (PCP, 1132).

127 Conservam-se na biblioteca de Murilo três obras de Góngora que provavelmente foram consultadas na época de realização de Tempo espanhol: Poemas y sonetos (Buenos Aires: Editorial S.A., 1939), Romances y letrillas (Buenos Aires: Editorial Losada, 1939) e Las soledades $\left(3^{\mathrm{a}}\right.$ ed. Madri: Sociedad de Estudios y Publicaciones, 1956).
} 
(...) Se dio cuenta de la fugacidad del sentimiento humano, de lo débiles que son las expresiones espontáneas que sólo conmueven en algunos momentos, y quiso que la belleza de su obra radicara en la metáfora limpia de realidades que mueren, metáfora dura, con espíritu escultórico y situada en un ambiente extraatmosférico.

Porque él amaba la belleza objetiva, la belleza pura e inútil, exenta de congojas comunicables.

Mientras que todos piden pan, él pide el hombro pórfido de cada día. Sin sentido de la realidad real pero dueño absoluto de su realidad poética. ${ }^{128}$

Tais discussões talvez tivessem chegado a Prudente de Moraes, neto, que ao resenhar o livro de estréia de Murilo, Poemas, em 1931, acrescenta entre outras "aproximações imprevistas", "o nome de D. Luis de Góngora, pois esqueceu-se de citar, entre os característicos da poesia do Sr. Murilo Mendes o uso intensivo da metáfora." ${ }^{129}$ O fato é que já desde o começo de sua obra o nome do poeta brasileiro era relacionado à literatura espanhola.

Os Estudios y ensayos gongorinos, de Dámaso Alonso, o grande especialista em Góngora que saiu da Geração de 27, tiveram várias passagens destacadas e / ou sublinhadas por Murilo. Dámaso define o conceito de metáfora em Góngora ao gosto moderno, pela aproximação de um plano "real e irreal": "Lo que es peculiar de la poesía de Góngora es o el esquivamiento completo de la realidad, o, más frecuentemente aún, el entrecruzamiento de los dos planos."130 Em "Lida de Góngora" representa-se esse encontro como uma movimentada batalha:

Furiosos metais, garras alternativas,

Tuas imagens concretas enfrentando

As harpias subterrâneas, vencem

Toda oposição entre os contrastes surdos

Do espaço linear e do tempo ondulado.

\footnotetext{
${ }^{128}$ LORCA, Federico Garcia. Poeta en Nueva York. Conferencias. Prosas póstumas. Buenos Aires: Editorial Losada, 1942, p. 92.

${ }_{129}$ MASSI, Augusto. Militante bissexto: o crítico Pudente de Moraes, neto. Tese de Doutorado. FFLCH - USP, 2004, p. 72.

${ }^{130}$ ALONSO, Dámaso. Op. cit., p. 42.
} 
Inversamente o grito vertical da ode

Convoca o vocabulário que se aduna

Em torno da metáfora, espada fértil:

Rompe a obscuridade em mil pedaços. (PCP, 594-595)

Mesmo depois de publicado Tempo espanhol, Góngora continuava a fascinar Murilo como verificamos nas anotações aos dois volumes de Góngora y el Polifemo, mais uma obra de Dámaso em quarta edição de $1961^{131}$, e principalmente no ensaio "Lenguaje poético: Góngora”, incluído em Lenguaje y poesía (1962), de Guillén. ${ }^{132}$ Além de tê-lo escolhido para sua tese de doutorado em $1924^{133}$, o autor de Cántico, para reforçar o caráter construtivo e visual da poesia de Góngora, vale-se de aproximações com a arquitetura e as artes plásticas: "Más que ninguno de sus contemporáneos españoles, quizá europeos, Góngora confiere a su poesía calidades de pintura, de escultura; tal vez la arquitectura sea el arte que aspire a emular. Lo extraño sería denunciar algún verso incoloro." ${ }^{134}$ Murilo observou também a associação entre a poesia de Góngora e os ofícios de arquiteto e de escultor, ao assinalar os poemas fúnebres que os representam, como "En la muerte de dos señoras mozas, hermanas, naturales de Córdoba", cujos dois versos iniciais trazem "Sobre dos urnas de cristal labradas,/ de vidrio en pedestales sostenidos,"135, e "De la capilla de nuestra señora del Sagrario, de la Santa Iglesia de Toledo, entierro del cardenal Sandoval", cujos dois primeiros quartetos descrevem a materialidade da urna:

\footnotetext{
Esta que admiras fábrica, esta prima pompa de la esculptura, oh caminante, en pórfidos rebeldes al diamante, en metales mordidos de la lima, tierra sella que tierra nunca oprima;
}

\footnotetext{
${ }^{131}$ Em cartão postal de 18 de abril de 1961, Murilo lembra a Dámaso a promessa do envio da obra (Arquivo Dámaso Alonso - Real Academia Española - Madri).

${ }^{132}$ Em carta de 16 de maio de 1962 a Guillén, ao agradecer o envio de Lenguaje y poesía, Murilo destaca o ensaio a respeito de Góngora como "o resumo de tudo o que se escreveu de melhor sobre o grande cordobês" (Arquivo Jorge Guillén - Biblioteca Nacional - Madri).

${ }^{133}$ V. GUILLÉN, Jorge. Notas para una edición comentada de Góngora. Edição de Antonio Piedra e Juan Bravo. Valladolid: Fundación Jorge Guillén/ Universidad de Castilha-La Mancha, 2002.

134 Fragmento destacado por Murilo. GUILLÉN, Jorge. Lenguaje y poesía. Madri: Revista de Occidente, p. 69.

${ }^{135}$ Versos sublinhados por Murilo. GÓNGORA, Luis de. Poemas y sonetos. Op. cit., p. 11.
} 
si ignoras cuya, el pie enfrena ignorante,

y esa inscripción consulta, que elegante

informa bronces, mármoles anima. ${ }^{136}$

Os comentários e poemas repercutiram provavelmente no poema "Arco de Góngora":

\section{(...)}

Mulheres que trazeis

A lua e o sol no corpo

Sustentado por duas colunas

De pórfiro e granito,

Também colunas do templo de Córdova:

Formastes Góngora.

(...)

Arquitetura e música deram a Góngora

O sentido da ordenação plástica do verso (PCP, 594)

\subsection{Rafael Alberti}

O registro mais antigo de contato entre Murilo Mendes e Rafael Alberti remonta a 25 de maio de 1957, data da dedicatória em exemplar de Office Humain, tradução de poemas de Murilo ao francês desse ano. ${ }^{137}$ Enquanto Murilo acabara de fixar residência em Roma, Alberti somente o faria em 1963, permanecendo até 1977, quando retornaria à Espanha depois de seu longo exílio. Vizinhos - Murilo morava na via del Consolato, e Alberti, na via Moserrato - freqüentavam-se em suas casas e nas ruas: "(...) encontramo-nos vez por outra no bairro, fazemos um passeio a quatro, incluindo Saudade."138 Por esse motivo não praticaram uma correspondência mais extensa, restando apenas uma carta de Alberti a Murilo de 16 de fevereiro, quando o espanhol estava na Côte d'Azur com Picasso, e a resposta de Murilo em

\footnotetext{
${ }^{136}$ Idem, ibidem, p. 64.

${ }^{137} \mathrm{~V}$. Anexos, Dedicatórias autógrafas em livros.

${ }^{138}$ Retratos-relâmpago. $1^{\text {a }}$ série (PCP, 1222).
} 
26 de fevereiro. ${ }^{139}$ A convivência entre os dois pode ser vista na comemoração do aniversário de Alberti na casa de Murilo em fevereiro de 1974, seqüência do documentário Murilo Mendes: a poesia em pânico (1977), dirigido por Alexandre Eulalio. Na ocasião, o poeta brasileiro mostrou ao aniversariante um poema que escrevera em sua homenagem. O poeta andaluz fez-Ihe um pedido: “¿Por qué no lees en alta voz? ¡Es muy bonito!” E Murilo acabou por recitar pausadamente: "Rafael Alberti sim/ aquele el matador/ Mata às vezes por ódio sempre por amor/ Trajando luzes/maneja a espada no ar/ Nem sempre veste o touro/ e veste sempre o mar/ Sendo o mar em espanhol/ também la mar traduzo/ Rafael pratica sempre a mar. ${ }^{140}$

Além de Office Humain e Tempo espanhol, Alberti contava em sua biblioteca com as edições italianas da poesia de Murilo, organizadas e traduzidas por Ruggero Jacobbi: Murilo Mendes (1961), Le metamorfosi (1964) e Poesia libertá (1971). ${ }^{141}$ Já nas estantes de Murilo, conservam-se, amplamente anotados, dois exemplares da obra albertiana: Entre el clavel y la espada (1939-1940) (Buenos Aires: Losada, 1941) e Pleamar (1942-1944) (Buenos Aires: Losada, 1944), ambos sem dedicatória, o que levanta a hipótese de uma leitura anterior a 1957, quando Alberti e Murilo se conheceram. Porém, Murilo não se limitou as duas coletâneas, pelo que depreendemos do retrato-relâmpago escrito sobre Alberti para a $1^{\text {a }}$ série de 1973. Entre vários livros, destacou Sobre los ángeles, "um poema que segundo Oreste Macrí constitui o texto maior do puro surrealismo espanhol" (PCP, 1225). No entanto, de outro hispanista italiano, Vittorio Bodini, destacou uma carta de Alberti de 7 de setembro de 1959, ao autor de Os poetas surrealistas espanhóis: "Yo nunca me he considerado un superrealista puro"142.

$\mathrm{Na}$ mesma obra, sublinhou a afirmação de que Alberti "é o único poeta marxista da Geração" ${ }^{143}$, pois valorizava o compromisso político na poesia dele, marcante na década de $30^{144}$ :

\footnotetext{
${ }^{139}$ V. Anexos, Correspondência de João Cabral de Melo Neto e Murilo Mendes com escritores espanhóis.

${ }_{140} \mathrm{O}$ poema, ao que se sabe, não teve nenhuma publicação. Por isso, o transcrevemos com uma marcação dos versos a partir da declamação do próprio Murilo.

${ }_{141}^{14}$ V. Anexos, Dedicatórias autógrafas em livros.

142 BODINI, Vittorio. I poeti surrealisti spagnoli. Torino: Einaudi, 1963.

${ }^{143}$ Idem, ibidem, p. XLV.

${ }^{144}$ V. Capítulo 1.
} 
(...) Rafael, o mais politizado dentre os poetas da sua geração, empenhou-se a fundo no drama do seu país. Lírico e revolucionário, encontra na paixão política um motivo de vida criadora: fustiga os imperialistas que tentam frear a marcha do mundo, precipitá-lo na guerra, soltar a bomba atômica. Dirige-se por exemplo à América do Norte: "Tu diplomacia del horror quisiera/ la intervención armada hasta en los astros." (...) E Rafael põe no ódio às coisas negativas a mesma força de paixão andaluza que revela no amor às coisas positivas: "Época es de morder a dentelladas", diz num verso enérgico de alto poder polêmico. (PCP, 1223)

Os versos, ainda atuais, pertencem a "Yo también canto a América", de 13 bandas y 48 estrellas (1936). Murilo compartilhou com Alberti o combate à ditadura franquista inclusive na dedicatória do livro Le metamorfosi: "Viva o amor - a liberdade - a poesia. Viva a Espanha livre. Abaixo o processo de Burgos, abaixo os netos dos inquisidores, falsos cristãos. VIVA A LIBERDADE! Roma. 16. 12. 1970." ${ }^{145}$ Refere-se ao Conselho de Guerra que se reuniu na cidade de Burgos nesse ano para julgar a execução de seis membros do grupo separatista do País Basco, o ETA, que provocou uma reação internacional. Alberti não ficou indiferente, escrevendo o poema "Condena", segundo ele próprio, nunca havia se sentido tão orgulhoso de ser um poeta comprometido. ${ }^{146}$

Mas também Murilo refletira sobre o alcance político da poesia. Em 1935 lembrara um juízo de Mário Pedrosa, para quem História do Brasil seria "um dos poucos livros nossos em que se afirma forte simpatia pelos oprimidos". ${ }^{147}$ História em versos que, a partir do exemplo do Pau-brasil de Oswald de Andrade, subverte a oficial dos grandes heróis e feitos, chegando às primeiras décadas do século $X X e$ seus conflitos nos sertões esquecidos: a Guerra de Canudos ("Milagre de Antônio Conselheiro"), a Coluna Prestes ("Marcha da Coluna") e o cangaço de Lampião ("Fuga"). Mais do que mero prosseguimento da vertente satírica do Modernismo dos anos 20, a História do Brasil de Murilo, ao abarcar o tempo presente, sintonizou-se

\footnotetext{
${ }_{145}^{145}$ Fundación Rafael Alberti - Puerto de Santa María - Cádiz.

146 V. ALBERTI, Rafael. La arboleda perdida. v. 2. Tercero y cuarto libros (1931-1987). Madri: Alianza Editorial, 2002, p. 245-246. Guillén também se manifestou sobre o caso no poema Guirnalda civil (Cambridge: Halty Ferguson, 1970), enviando um exemplar a Murilo, que the agradeceu em carta de 1 de janeiro de 1971: "Obrigado por seu admirável Guirnalda civil, vinda no momento exato: o momento do incrível processo de Burgos. Que nos fez sofrer muito e nos tem provocado muitas insônias. Uma vez mais a palavra de um grande poeta nos conforta em meio a tantas injustiças e crueldades." (Arquivo Jorge Guillén - Biblioteca Nacional - Madri).

${ }^{147}$ MENDES, Murilo. "A poesia e os confusionistas". Boletim de Ariel. a. 5, n. 3, Rio de Janeiro, dez. 1935, p. 63.
} 
com a afirmação das posições políticas e das questões sociais da década de 30 , podendo ser considerada uma transição do "projeto estético" para o "projeto ideológico", segundo a pertinente distinção de João Luis Lafetá. ${ }^{148}$

Em um contexto em que se fazia necessário denunciar e expor, ganham força na literatura brasileira o romance regionalista e os ensaios históricos e sociológicos. A poesia, embora se afirmassem suas principais vozes modernas, vinha sendo questionada em relação ao seu compromisso político. Para completar o quadro de dissidências, no caso de Murilo, após a morte de Ismael Nery, em 1934, voltou-se intensamente ao catolicismo, disseminado nas obras do período: os poemas de Tempo e eternidade (1935) e A poesia em pânico (1937), e a prosa de $O$ sinal de Deus (1936). No entanto, ele não fugiu às discussões, defendendo seu ponto-devista em periódicos como Boletim de Ariel e Dom Casmurro. Quando da publicação de Calunga (1935), experiência de Jorge de Lima no romance regionalista, aproveitou a oportunidade para defender a face social da poesia religiosa:

A confusão em torno da literatura "proletária" aumenta dia a dia no Brasil, embora Trotski, Rosa Luxemburgo e outros já tivessem posto os pontos nos ii. Esta chegou mesmo a escrever que o fim da arte é comover a alma humana, qualquer que seja a posição política do artista. É claro que não existe arte desinteressada, o que varia são os alvos do interesse. Nada mais interessado do que, por exemplo, a poesia religiosa, a poesia que converge para Deus; pois que Deus é o supremo interesse. ${ }^{149}$

Reage às declarações como a de Manuel Bandeira sobre a impotência da poesia frente à questão social, não compreendendo as duas como inconciliáveis:

(...) É preciso tomar a sério a questão social. Isto não impede de tomar também a sério a poesia. A poesia não poderá acabar enquanto houver um alento de vida no mundo. A poesia não pode ser interrompida porque existe a questão social. Isto é para os trouxas. Quanto a mim acho formidável ser poeta; sei que a poesia é eterna, definitiva, inexpugnável, - e que todos os políticos, economistas, "simpatizantes", críticos, editores e ensaístas não prevalecerão contra ela. ${ }^{150}$

\footnotetext{
148 LAFETÁ, João Luiz. 1930: a crítica e o modernismo. São Paulo: Duas Cidades; Editora 34, 2000.

149 "Calunga". Boleteim de Ariel. a. 4, n. 11, Rio de Janeiro, ago. 1935, p. 291.
} 
Mas os tempos tornaram-se mais sombrios. O drama da Guerra Civil Espanhola entrava no horizonte das preocupações de Murilo, assinando juntamente com José Lins do Rego, Graciliano Ramos e Caio Prado Junior, entre outros, o manifesto "Os intelectuais brasileiros e a democracia espanhola", enviado à Espanha e divulgado em setembro de 1937 em Dom Casmurro. ${ }^{151}$ A exemplo de outros poetas brasileiros $^{152}$, expressou sua indignação pelo assassinato de Lorca no "Poema do espanhol", publicado em Mundo enigma (1942).

Em As metamorfoses, Mundo enigma e principalmente Poesia liberdade, Murilo transfigura os horrores da Segunda Guerra Mundial em desconcertantes imagens. Essas obras, compostas entre 1938 a 1945, relacionam-se com Entre el clavel y la espada - dedicada a Pablo Neruda - e Plemar, elaboradas também nesse conturbado momento. Em seu exemplar de Entre el clavel y la espada, assinalou o prólogo intitulado "De ayer para hoy":

Hincado entre los dos vivimos: de un lado, un seco olor a sangre pisoteada; de otro, un aroma a jardines a amanecer diario, a vida fresca, fuerte, inexpugnable. Pero para la rosa o el clavel hoy cantan pájaros más duros, y sobre dos amantes embebidos puede bajar la muerte silbadora desde esas mismas nubes en que soñaran verse viajando, vapor de espuma por la espuma. ${ }^{153}$

O "cravo" e a "espada" representam, respectivamente, a poesia pura e a poesia comprometida, confronto que a poesia de Alberti e a espanhola enfrentaram nas décadas de 20 e 30 . O poeta, na nova fase de sua obra, propõe que as duas tendências não sejam excludentes, mas que possam alternar-se, conviver. Essa postura "dualista" convinha mais à poética de Murilo.

Ainda sobre uma poesia social, em 1953, Murilo recebeu o Romanceiro da Inconfidência de Cecília Meireles como um exemplo de "alta categoria" de poesia social:

\footnotetext{
150 "Manuel Bandeira cai no conto do vigário". Boletim de Ariel. a. 5, n. 2, nov. 1935, p. 38.

151 "Nós intelectuais brasileiros, patriotas e democratas, fiéis a nossa própria consciência, não podemos silenciar mais ante o que se passa nas terras desgraçadas da Espanha.// Esta nossa atitude tem apenas o sentido de uma pura demonstração de amor à liberdade e à cultura, tão ameaçadas pelas hordas do fascismo internacional, no país que deu ao patrimônio da humanidade figuras como Goya e Cervantes." (Dom Casmurro. a. 1, n. 17, Rio de Janeiro, 2 de setembro de 1937).

152 "A Federico Garcia Lorca" de Carlos Drummond de Andrade em Novos poemas (1948). V. CARVALHO, Ricardo Souza de. Notícias de Lorca por Drummond. Cd-rom Congresso Internacional O mundo, vasto mundo de Drummond - 14 a 16 de maio de 2002 - UFRJ.
} 
(...) A poesia social sempre me seduziu. De resto, tentei-a várias vezes. O que desaprovo é a poesia tipo manifesto e programação política, cumprindo desajeitadamente um papel que antes compete ao artigo de jornal e à literatura de comício - à prosa, enfim. Na mesma ordem de idéias um certo tipo de pintura social que retira o poeta do seu pequeno mundo ambiente, e cortando o cordão umbilical do egoísmo e do individualismo, abre-lhe perspectivas muito mais vastas, dentro da dimensão histórica ou do mito, esta me parece ser o caminho mais fecundo e com maiores possibilidades de futuro. ${ }^{154}$

A poesia "tipo manifesto e programação política" fora experimentada algumas vezes por Alberti na década de 30. Quanto a Murilo, seus poemas comprometidos mais acabados apareceram justamente em Tempo espanhol, enfrentando totalmente a "dimensão histórica" "155: "O chofer de Barcelona", "O padre cego" e o que encerra a coletânea, "O Cristo subterrâneo". No primeiro, o eu lírico deixa falar a "palavra ácida" do taxista, plena de inconformismo e revolta:

\author{
Não temos mais solução. \\ Cada dia nos embromam \\ Com discursos, fiestas, fiestas, \\ Corridas e procissões. \\ Falta o pão, falta o trabalho, \\ A escola não dá pra todos. \\ Espero em vão há sete anos \\ Rever meus pais em Oviedo. (PCP, 615-616)
}

Murilo tomou conhecimento da poesia espanhola mais recente de caráter social, nas antologias de José Luis Cano ${ }^{156}$ e de José Maria Castellet. ${ }^{157}$ No prefácio de Castellet, assinalou uma citação do artigo "El poeta y las fases de la realidad", de Pedro Salinas: "Considero imposible que por muy fuertes que sean las murallas del concepto individual de la poesía puedan resistir a la inmensa presión de esa

\footnotetext{
${ }_{153}^{15}$ ALBERTI, Rafael. Entre el clavel y la espada (1939-1940). Buenos Aires: Losada, 1941, p. 15.

154 MEIRELES, Cecilia. Obra poética. Op. cit., p. 52-53.

${ }^{155} \mathrm{~V}$. Capítulo 6.

156 Antología de la nueva poesía española. Madri: Gredos, 1958. Na folha de rosto, há indicação manuscrita de Murilo: "Murilo Mendes. Barcelona, Agosto 1958".

${ }_{157}$ Veinte años de poesía española. 1939-1959. Barcelona: Seix Barral, 1960. Na folha de rosto, há indicação manuscrita de Murilo: "Murilo Mendes. Madrid, setembro 1960".
} 
obsesión política y social." ${ }^{\prime 158}$ Entre outros, destacou versos de Gabriel Celaya e Blas de Otero, exemplos no prefácio de Cano de "poesia desarraigada", termos de Dámaso Alonso, ou seja, uma poesia não puramente estética, mas que também abrange os problemas do homem e seu destino. ${ }^{159}$ Estusiasmou-se, nessas antologias, com Miguel Hernández, pois, além do poema em Tempo espanhol, dedicou-lhe um retrato-relâmpago na $1^{\text {a }}$ série, apresentando seu destino literário, de comunicação com o público, como "antagônico à sua época" de formalismo:

(...) Nosso poeta formou-se sob o signo dum fato fundamental da cultura moderna, denunciado por José Ortega y Gasset - o processo de desumanização da arte, chegado agora ao seu clímax. Nesse diagrama da cultura as noções de poeta e poesia sofreram um deslocamento. O poeta perde contato com um público tornado estranho aos antiqüíssimos conceitos de magia e iluminação, que se haviam prolongado até ao simbolismo. O poema passa a ser considerado uma forma autônoma, impessoal, construída sem intervenção do sentimento; poema transformado já agora em objeto, planificado pelo engenheiro. Termina a era dos "vates", homem de missão. (PCP, 1220-1221)

\subsection{Vicente Aleixandre}

A dedicatória em 10 de outubro de 1958 de Vicente Aleixandre em exemplar de La destrucción o el amor ${ }^{160}$ alude a uma "conversa em poesia e amizade" com Murilo Mendes. Provavelmente corresponde à visita lembrada pelo brasileiro em Espaço espanhol, na parte dedicada a Madri: “(...) Apesar da saúde frágil (vive com um só rim) parece robusto; grandão, corado. Gesticula muito; os olhos claros, móveis, espicaçam o visitante. Entre uma copita e outra de Jerez lê-me alguns de seus últimos textos, batendo com a mão no papel; (...)" (PCP, 1131). Não encontramos outros registros, como dedicatórias e correspondência, que comprovem a continuaçao da amizade inicial.

Além dos textos escutados - talvez os que formariam En un vasto dominio (1962) -, leu e anotou muito o já mencionado La destrucción o el amor e o volume

\footnotetext{
158 Idem, ibidem, p. 94.

${ }_{159}$ Antología de la nueva poesía española. Op. cit., p. 15.

${ }^{160} \mathrm{~V}$. Anexos, Dedicatórias autógrafas em livros.
} 
que reúne Espadas como labios e Pasión de la tierra, este com autógrafo na folha de rosto: "Murilo Mendes. Barcelona, Agosto 1958". Murilo interessava-se pelo Aleixandre "cultor da metáfora dentro da tradição gongorina renovada por ele com a ajuda do surrealismo." (PCP, 1131).

É justamente o surrealismo o forte ponto em comum entre Murilo e Aleixandre. No entanto, tanto eles, quanto a crítica, descartaram uma adesão incondicional às propostas de Breton no Manifesto surrealista, principalmente no que se refere à escrita automática. Mário de Andrade, sobre os Poemas (1930), já o apontava: “(...) não é um surréaliste no sentido de escola, porém me parece difícil da gente imaginar um aproveitamento mais sedutor e convincente da lição surrealista. Negação da inteligência superintendente, negação da inteligência seccionada em faculdades diversas, anulação de perspectivas psíquicas, intercâmbio de todos os planos". ${ }^{161}$ Dámaso Alonso, ao comentar La destrucción o el amor (1935), investe na mesma direção: “(...) La poesía de Aleixandre, como toda aquella parte de la moderna que está más o menos emparentada con el surréalisme francés y su pretendido automatismo, vuelve, por fuerza, a buscar el descansadero de una forma. Entiéndese bien: de una forma que, repito, nada tiene que ver con la forma clásica, sino de una forma vital, individual e individualizante, necesaria para hacer resaltar superficialmente la profunda unidad del poema."162 A última frase, aliás, foi sublinhada por Murilo em sua edição de Poetas españoles contemporáneos.

Se na literatura brasileira as experiências surrealistas muitas vezes foram recalcadas a favor de um programa nacionalista ${ }^{163}$, na espanhola, a discussão tornou-se mais complexa, pois se elaboraram obras mais vinculadas com a

\footnotetext{
${ }^{161}$ ANDRADE, Mário de. A poesia em 1930 In Aspectos da literatura brasileira. São Paulo, Martins, s.d., p. 42.

${ }_{162}$ ALONSO, Damaso. La poesía de Vicente Aleixandre In Poetas españoles contemporáneos. Madrid: Gredos, 1958, p. 303.

${ }_{163}$ Mário de Andrade, em carta de 25 de dezembro de 1927, adverte Prudente de Moraes, neto, contra os riscos do surrealismo em um momento de "construção" da literatura brasileira: "(...) $O$ sobrerrealismo é uma arte quintessenciada que me atrairia fatalmente si eu não me tivesse dado uma função de acordo mais com a civilisação e o lugar em que vivo. Porquê incontestavelmente a civilisação em que a gente vive no Brasil não é a mesma dos franceses não acha mesmo? (...) me parece que não estamos naquele momento de fadiga em que está a arte francesa com seculos de tradição organisada nacionalmente, atrás dela. (...) No Brasil acho que no momento atual, pros que estão de deveras acomodados dentro da nossa realidade, êle não adianta nada. Não adianta porquê não ajuda. Todas as questões que são de vida ou de morte prá organisação definitiva da realidade brasileira (coisa que indiscutivelmente está se dando agora) nos levam pra uma arte de caracter interessado que como todas as artes de fixação nacional só pode ser essencialmente religiosa (no sentido mais largo da palavra; fé pra união nacional, psicologia familiar social religiosa sexual)." (KOIFMAN, Georgina, org. Cartas de Mario de Andrade a Prudente de Moraes, neto. 1924/1936. Rio de Janeiro: Nova Fronteira, 1985, p. 247-249).
} 
vanguarda francesa, como Sobre los ángeles, de Alberti, e Poeta en Nueva York, de Lorca. Contudo, tanto Aleixandre, quanto Murilo, em mais de uma ocasião, procuraram esclarecer suas dívidas para com o surrealismo. Segundo Aleixandre, Pasión de la tierra, poemas em prosa escritos entre 1928 e 1929, trata-se de seu livro, "el más próximo al superrealismo, aunque, como he dicho más de una vez, fuera de esa escuela, pues no he creído nunca en sus dogmas: la escritura automática y la abolición de la conciencia artística." ${ }^{164}$ Posteriormente, no prólogo a uma seleção de sua "poesía superrealista”, provoca: “¿Pero hubo en este sentido, alguna vez, un verdadero poeta superrealista?"165 Murilo também questiona os limites da estética surrealista: "Claro que pude escapar da ortodoxia. Quem, de resto, conseguiria ser surrealista em regime de full time? Nem o próprio Breton." (PCP, 1238).

Além do contato com o surrealismo, que remontava às décadas de 20 e 30 , Aleixandre e Murilo, naquele final dos anos 50, coincidiam na busca de uma poética mais depurada. Sobre Historia del corazón, o próprio Aleixadre acreditava representar "una nueva etapa y una renovación en la técnica. En el estilo, una desnudez máxima en el proceso de aclaración expresiva." ${ }^{166}$ Como o Murilo no artigo "A poesia e o nosso tempo", Aleixandre vinha chamando a atenção para a necessidade da comunicação em lugar de uma estrita preocupação formal: "La comunicación que la poesía in actu establece entre los hombres, entre otras cosas, prueba conmovedoramente lo ridículo de las 'torres de marfil'. Por no decir su inmoralidad." 167; "La forma, en poesía, no es cárcel ni ornamento; es sencillamente la justa y coloreada apariencia visible." 168

\subsection{Dámaso Alonso}

O primeiro contato entre Murilo e Dámaso Alonso data de 10 de outubro de 1958, de acordo com a dedicatória a um exemplar de Antología crítica (1956) que

\footnotetext{
164 "Apuntes para una autobiografía" In Prosa. Edição de Alejandro Duque Amusco. Madri: Espasa Calpe, 1998, p. 330.

165 Poesía superrealista. Antología. Barcelona: Barral, 1971, p. 7.

166 "Cinco preguntas en cinco minutos" In Prosa. Op. cit., p. 292.

167 Idem, ibidem, p. 399.

${ }^{168}$ Idem, ibidem, p. 403.
} 
registra "la compañía poética y la amistad naciente - y esperemos que larga". ${ }^{169}$ Entre encontros e desencontros em Madri e Roma, os dois poetas mantiveram uma pequena correspondência de 19 de março de 1959 a 19 de setembro de $1969 .{ }^{170}$ Ao relembrar um deles, na parte "Madri" de Espaço espanhol - aliás, dedicado à Dámaso e Guillén como "Grandes de Espanha" - deixou traços peculiares do amigo: "Os óculos dançam-lhe no rosto; quase descem até o queixo; a cabeça não pára. Tem eletricidade até no bigode." (PCP, 1131).

$\mathrm{Na}$ biblioteca de Murilo, avulta mais o crítico do que o poeta, pois foi como crítico que Dámaso afirmou-se em sua geração: 7 volumes contra um exemplar de Hijos de la ira, na segunda edição de 1946. Antes dessa coletânea decisiva, publicara Poemas puros. Poemillas de la ciudad (1921), El viento y el verso (1925) e Oscura noticia (1944).

Denominando-o de "crítico-poeta", Murilo não deixou em segundo plano a poesia: “(...) A mole da sua obra crítica parece ter obscurecido diante do leitor estrangeiro a do poeta. Mas na Espanha até mesmo os novíssimos admiram seus livros de poesia, inseridos na grande geração de 1927; resultantes da fértil aliança entre tradição e modernidade 'fluyendo como la leche la ubre caliente de una gran vaca amarilla"' (PCP, 1131). Este é o $3^{\circ}$ verso do poema inicial de Hijos de la ira, "Insomnio", que começa de forma impactante: "Madrid es una ciudad de más de un millón de cadáveres." Em texto da década de 60, "Poesia espanhola e realidade", também realça a importância do Dámaso poeta, cujo Hijos de la ira abria um "novo capítulo na história da poesia espanhola":

Contudo em certos períodos abre-se um parêntese nessa grande tradição humanístico-realista. Por exemplo a poesia espanhola deste século sofreu durante muito tempo as vicissitudes provenientes dum estreito formalismo cujo representante mais ilustre foi Juan Ramón Jimenez. O processo de desenvolvimento dessa fórmula tinha chegado ao seu ponto extremo de saturação quando Dámaso Alonso publica em 1944 o livro Hijos de la Ira, justificando anos mais tarde sua nova posição com estas palavras: 'Não há nada que eu aborreça mais agora do que o estéril esteticismo em que se debateu durante mais de meio-século a arte contemporânea.

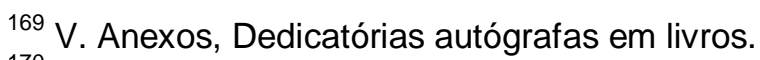

170 V. Anexos, Correspondência de João Cabral de Melo Neto e Murilo Mendes com escritores espanhóis.
} 
Hoje só me interessa o coração do homem. Chegar a ele segundo as oportunidades, seja por caminhos de beleza, seja por meio de arranhões." (PCP, 1471)

Murilo retirou o desabafo de Dámaso do texto "Una generación poética (19201936)", de seu exemplar de Poetas españoles contemporáneos, concordando com o poeta espanhol a respeito dos impasses do formalismo em poesia.

Dámaso também se ocupou da poesia do amigo brasileiro. Na abertura do primeiro número da Revista de Cultura Brasileña, de junho de 1962, publicou sua tradução de "Poemas de Murilo Mendes". Sua nota preliminar ${ }^{171}$, após situá-lo na literatura brasileira, parte para a mundial, na qual participa do "grande movimento que descobre o valor poético do subconsciente, dos sonhos e dos impulsos primários, representados antes de tudo pelo 'surréalisme' francés". No entanto, da mesma forma como analisou a poesia de Aleixandre, não vê em Murilo um “'seguidor' de uma moda". Caracteriza a poesia dele como uma "oscilação entre elementos conceituais ligados por lógica e elementos puramente imaginativos". Como exemplo da primeira tendência oferece Tempo e eternidade, do qual, aliás, não escolheu nenhum poema para sua seleção. Quanto aos "elementos puramente imaginativos", pólo predominante da obra muriliana, não são de mero "amontoamento", pois os "fragmentos que parecem inconexos se associam para produzir a intuição total do poema na mente do leitor". Desde a "Poética" que escreveu para Poesía española. Antología 1915-1931, organizada por Gerardo Diego, defendia certa organização do poema que destoava dos princípios do surrealismo: “(...) Resuelve en palabras los elementos de su profunda conciencia, elimina los menos significativos, los enlaza por medio de un número mayor o menor de elementos lógicos y no poéticos... (El automatismo no ha sido practicado ni aun por sus mismos definidores)."

Baseado na edição de Poemas 1925-1955 ${ }^{173}$, mencionada na nota preliminar, selecionou 10 textos, aparte 2 de Tempo espanhol, apresentando não apenas um panorama, mas também sugerindo um percurso poético. Os seis primeiros, ou seja, a metade deles, de obras escritas entre 1930 e 1942, são mais

\footnotetext{
${ }^{171}$ V. Anexos.

${ }_{172}^{172}$ Edição fac-simil de 2002. Madri: Visor Libros, 2002, p. 219.

${ }^{173} \mathrm{Na}$ biblioteca de Dámaso Alonso (Real Academia Española - Madri) não consta esse livro, apenas a tradução italiana de Giuseppe Ungaretti de Finestra del caos (1961). V. Anexos, Dedicatórias autógrafas em livros.
} 
discursivos, de versos longos, o que indica uma preferência do próprio Dámaso, na medida em que passou a praticar versos dilatados e imagens fortes em Hijos de la ira, distante da contenção dos Poemas puros. Poemillas de la ciudad. O longo "Jandira" de $O$ visionário, por exemplo, teria chamado a atenção de um Dámaso que experimentou também a linguagem coloquial e a técnica narrativa em Hijos de la ira. Além disso, não resistiu a um convulso "Poema barroco", de Mundo enigma, já que o qualificativo relaciona-se com seus numerosos estudos do século XVII. Os seis poemas restantes, de obras produzidas entre 1943 a 1959, apontam para um processo de concisão da linguagem.

\subsection{Jorge Guillén}

O ano de 1958, tão rico para as amizades espanholas de Murilo, registra uma respeitosa dedicatória em exemplar de Office Humain: "A Jorge Guillén, poeta ilustre, homenagem de antiga admiração e simpatia de Murilo Mendes. Nápoles, 19.12.1958". A "antiga admiração" pode ter surgido de uma leitura de Cántico por intermédio de Cabral, que o havia recomendado a Bandeira já em 1947. ${ }^{174}$ Nápoles, por sua vez, mostra que a Itália seria o espaço privilegiado de encontro entre Murilo e Guillén; o poeta espanhol visitou o país várias vezes, principalmente Roma e Florença, onde se encontrava com grandes amigos, alguns comuns a Murilo. ${ }^{175}$

Murilo manteve com Guillén a correspondência mais longa, das localizadas, com escritores espanhóis, de 2 de março de 1959 a 20 de outubro de $1974 .{ }^{176} \mathrm{Em}$ sua biblioteca, além dos ensaios de Lenguaje y poesía, existem apenas dois livros de poemas de Guillén, A la altura de las circunstancias (1963), o terceiro volume de Clamor, e $Y$ otros poemas (1973). No entanto, as cartas acusam o recebimento de outras obras: Clamor. Maremágnum (1957) ${ }^{177}$, Según las horas e Las tentaciones de Antonio, ambas editadas em $1962^{178}$, Homenaje (1967) ${ }^{179}$, e Aire nuestro (1968), reunião dos ciclos Cántico, Clamor e Homenaje. ${ }^{180}$

\footnotetext{
${ }^{174}$ V. Capítulo 1.

${ }^{175}$ Sobre as relações de Guillén com a Itália, v. DOLFI, Laura, org. Cartas inéditas (1953-1983). Jorge Guillén - Oreste Macrí. Valencia: Pre-Textos, 2004.

${ }^{176}$ V. Anexos, Correspondência de João Cabral de Melo Neto e Murilo Mendes com escritores espanhóis.

${ }_{177}$ Carta de 2 de março de 1959 (Arquivo Jorge Guillén - Biblioteca Nacional - Madri).

${ }^{178}$ Carta de 14 de fevereiro de 1963 (Arquivo Jorge Guillén - Biblioteca Nacional- Madri).
} 
Em contrapartida, a obra muriliana está razoavelmente representada na biblioteca de Guillén: Siciliana e Tempo espanhol, de 1959; as traduções italianas de Finestra del caos (1961) por Ungaretti e da antologia de 1961 organizada por Rugero Jacobbi; e as traduções espanholas de Poemas de Murilo Mendes (1962) por Dámaso Alonso e de Siete poemas inéditos (1965) por Ángel Crespo e Dámaso. ${ }^{181}$

Além dos livros de poesia, o ensaio "Los impulsos elementales en la poesía de Jorge Guillén" em Poetas españoles contemporáneos, de Dámaso, esteve presente na recepção da obra guilleniana por Murilo. Entre várias anotações, assinalou, ao final do estudo, o objetivo do crítico de ir mais além da tradicional percepção "intelectualista", reconhecendo uma dimensão mais "humana", "primitiva":

¡Patente, pues, evidente, el "intelectualismo" de Guillén! Patente también que su poesía brota muchas veces de las sensaciones más elementales del hombre, de impulsos y gozos comunes. Del Guillén exacerbador de lo intelectual, del Guillén artista perfecto, se ha hablado bastante veces - y será aún necesario que se hable mucho más -. Pero poco o nada se había dicho del Guillén humanísimo, y casi "animalísimo", primario, potencializador de los instintos elementales. ${ }^{182}$

João Cabral, outro admirador brasileiro de Guillén, como vimos, valorizava apenas a faceta de poeta que domina seu ofício. Quanto a Murilo, interessou-se por um poeta que encontrara uma possível solução para as tensões entre impulsos vitais e organização formal que experimentava desde o início de sua obra, e que no artigo "A poesia e o nosso tempo", de 1959, não entende como antagônicos: "Não creio que a preocupação com as pesquisas da linguagem se oponha à 'iluminação', não creio que o 'fazer' se oponha ao sentir, ao amar, ao se entusiasmar. Em outras palavras, não creio que a afetividade possa desaparecer da poesia." E assim resolve o conflito: "Resumindo, pode-se dizer que a operação poética é baseada em linguagem, afetividade e engenho construtivo." 183

\footnotetext{
${ }^{179}$ Carta de 3 de setembro de 1967 (Arquivo Jorge Guillén - Biblioteca Nacional- Madri).

180 Carta de 22 de janeiro de 1979 (Arquivo Jorge Guillén - Biblioteca Nacional- Madri).

$181 \mathrm{~V}$. Anexos, Dedicatórias autógrafas em livros.

182 Op. cit., p. 242.

183 Op. cit., p. 55.
} 
A passagem do ensaio de Dámaso seria utilizada em um texto de Murilo intitulado "Jorge Guillén", que permaneceu inédito. ${ }^{184}$ Segundo carta de 6 de fevereiro de 1967 a Guillén, inicialmente fora pensado para fazer parte do livro Figuras, primeiro nome para os Retratos-relâmpago. Anos depois, em 20 de outubro de 1974, enviou um manuscrito de 5 folhas como "modesta homenagem", justificando que ultrapassara os limites da obra publicada no ano anterior. Como em vários momentos da correspondência, sintetiza a principal confluência entre as poéticas de ambos: "Espírito dialético por inclinação e cultura, diria que reúne pontos inconciliáveis: subjetividade e objetividade, abstrato e concreto, imanência e transcendência."

A concisão foi outro aspecto da obra de Guillén que agradou a Murilo, destacada a partir da leitura de Según las horas, incluído posteriormente em Homenaje. Em carta de fevereiro de 1963, elogia a "poesia em cápsulas, revelação moderna do hai kai", mencionando 9 poemas. Identifica também neles uma "aceitação do mundo em fórmulas rápidas, lapidares, mesmo quando as envolve um pouco de sombra. Resumo e conclusão feliz: (...)", citando o último verso do poema "A la recíproca" que encerra a coletânea:

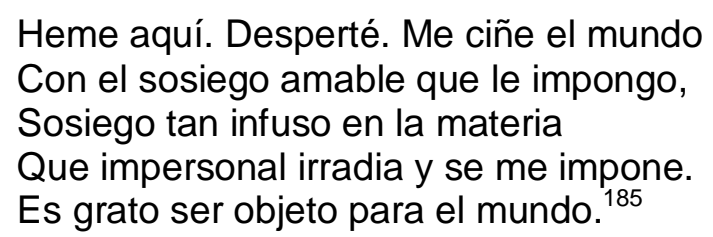

Sintomaticamente, nesse 1963, Murilo deu início aos poemas de Convergência, obra decisiva no processo de "lapidação" buscado em Tempo espanhol. Os dois poetas também coincidiram na eleição de escritores e artistas como tema para a poesia: as séries dos "Grafitos" e "Murilogramas" de Convergência, e a série "Al margen" de Homenaje.

Mas Guillén não deixou de se manifestar em relação à poesia de Murilo. Em sua última obra publicada, Final (1981), escolhe para epígrafe do poema "La materia" os versos "A matéria é forte e absoluta/ Sem ela não há poesia.", de Murilo:

\footnotetext{
${ }_{184} \mathrm{~V}$. Anexos.

${ }^{185}$ Homenaje. Reunión de vidas. Edição fac-simil. Madri: Visor Libros, 2003, p. 553.
} 
Poesía, espiritual conato.

Por entre las palabras y el espíritu, Intuiciones, visiones, sentimientos, Jamás pura abstracción. Se apoya siempre

Sobre eso que está ahí, total materia

Compacta de elementos muy concretos

Que nos salvan: rehúsan el vacío. ${ }^{186}$

O poema integra a quarta parte da obra, "Tiempo fechado" (Tempo datado), cujos versos de abertura da seção inicial anunciam: "Si bien lo dices,/ Si es justa la expresión, nos pacifica./ Justa correspondencia:/ Realidad y palabra."

Quanto aos versos de Murilo, corroboram a posição de Guillén, explorada desde Cántico, de que a poesia, ainda que tente atingir uma esfera "espiritual", depende da "matéria" para se constituir. Assim, eles parecem ser uma divisa para o Murilo que experimentava uma poesia a partir de um "objeto", de um "tema", usando os termos de Cabral na carta de 1959. No entanto, trata-se dos versos finais de "Poema espiritual", de A poesia em pânico, o qual também fora escolhido para a seleção de Dámaso em 1962:

Eu me sinto um fragmento de Deus

Como sou um resto de raiz

Um pouco de água dos mares

O braço desgarrado de uma constelação.

A matéria pensa por ordem de Deus,

Transforma-se e evolui por ordem de Deus.

A matéria variada e bela

É uma das formas visíveis do invisível.

Cristo, dos filhos do homem és o perfeito.

Na lgreja há pernas, seios, ventres e cabelos

Em toda parte, até nos altares.

Há grandes forças de matéria na terra no mar e no ar

Que se entrelaçam e se casam reproduzindo

Mil versões dos pensamentos divinos.

A matéria é forte e absoluta

Sem ela não há poesia. (PCP, 296-297)

Talvez, no caso de Dámaso, sua experiência com uma poesia religiosa escrevera a coletânea Hombre y Dios - tivesse direcionado a escolha desse poema e de "O fogo" de Os quatro elementos. Por outro lado, "Poema espiritual" apresenta,

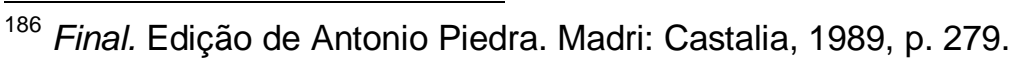


com a intenção de expressar crenças, os "versos inúteis", as "banalidades ineficazes" de que falara Mário na crítica à coletânea que mencionamos. Os versos finais sobressaem do conjunto, sinalizando que a preocupação com o "objeto" estaria ao longo da obra muriliana e atingiria os pontos cruciais em Tempo espanhol e Convergência. Guillén justamente "recortou" os contundentes versos que lhe interessavam, sem a mensagem católica, pois o seu poema volta-se à "matéria".

\section{Entre os novos poetas}

\section{1. Ángel Crespo}

Uma dedicatória em exemplar de Tempo espanhol marca o "primeiro contato pessoal" entre Murilo e Ángel Crespo em 16 de novembro de 1960. O poeta brasileiro de 59 anos, que escrevera praticamente toda a sua obra poética e se enveredava pela prosa, encontrava-se com o poeta espanhol de 34 anos em plena atividade, contando já com 8 livros de poesia ${ }^{187}$ e 2 traduções de poesia portuguesa publicados. ${ }^{188}$ Apesar dessa volumosa produção, a qual se somariam novos títulos nos anos seguintes, na biblioteca de Murilo apenas resta a seleção e prólogo de Crespo a Algunos poemas (1966), de Eduardo Chicharro. Mas pelo menos lera vários poemas de Crespo nas antologias citadas de Cano e Castellet. Nas estantes de Crespo, além de Tempo espanhol, permanecem Poesias 1925-1955 (1955) e as edições italianas que também foram enviadas a Alberti, Dámaso e Guillén: Finestra del caos (1961), a antologia de Rugero Jaccobbi (1961) e Italianissima. 7 Murilogrammi (1965). ${ }^{189}$

Em várias ocasiões, Crespo viajou à Itália, desenvolvendo estreitos laços com esse país, dos quais resultaram o livro de poemas Docena florentina (1966) e as traduções de Dante e Petrarca. Dessa maneira, tornou-se um novo espaço de contato com Murilo, como deixou registrado em seu diário uma visita "surpresa" na via del Consolato em 1972:

\footnotetext{
187 Primera antología de mis versos (1949), Una lengua emerge (1950), Quedan señales (1952), La pintura (1955), Todo está vivo (1956), La cesta y el río (1954-1957) (1957), Junio feliz (1959) e Oda a Nanda Papiri (1958).

${ }^{188}$ Poemas de Alberto Caeiro (1957) e Pliego de poesía portuguesa (1960).

${ }^{189}$ V. Anexos, Dedicatórias autógrafas em livros.
} 
El día veintidós (cuando se fue Pilar, me acosté pronto y no me desperté hasta las cinco y media de la tarde) salí a dar un paseo y, de pronto, me encontré frente a la casa de Murilo Mendes. Decidí subir a verle. Estaban en casa la mujer y él; eran las siete y media, iban a cenar y cenamos juntos. Le encuentro - le encontré - muy envejecido y poco ágil en su trato. Tardó en reponerse de la sorpresa de mi inesperada visita: estaba torpe y como balbuciente. Cuando se hubo recuperado fue el Murilo de siempre: simpático, 'sofisticado', brasílico - apátrida. Muy cuidadoso de su obra me mostró sus inéditos y su nuevo libro de Academia-Sansoni [Poesia libertà. Edição de Ruggero Jacobbi. Milão, 1971]. Me habló con entusiasmo de Rafael Alberti, y yo me callé. Me acuerdo ahora de esta visita porque durante estos días todo el mundo me ha hablado de Alberti sin entusiasmo: Mario Di Pinto, Dario Puccini, José Gotory y algunos más."190

Conservam-se apenas duas cartas de Murilo a Crespo, de 14 de julho de 1968 e 5 de julho de 1970, período em que o espanhol mudou-se para Porto Rico como professor do Recinto Universitário de Mayagüez. Na carta de 1970, comenta que guardava todos os números da Revista de Cultura Brasileña, "bom instrumento de trabalho". Vale lembrar que ele próprio ocupou as primeiras páginas do número inaugural de 1962 na tradução de Dámaso. Ao atingir o 30, em março de 1970 , Crespo renunciara à direção da revista.

Ao longo desses nove anos, a Revista de Cultura Brasileña tornou-se um veículo fundamental para que Murilo, distante do Brasil, refletisse sobre as experiências mais recentes de sua poesia e a do seu país. Crespo preocupava-se em atualizar o público espanhol a partir da produção brasileira:

(...) Sin olvidar la historia ni los principales aspectos de la rica y contradictoria actualidad literaria del Brasil, di un lugar destacado en las páginas de aquella publicación a las corrientes de carácter experimental porque pensaba que, siendo como eran internacionales, es decir, muy relacionadas con las de otros países, merecía la pena informar sobre ellas a los lectores españoles. Es que continuábamos teniendo un arte de vanguardia y, paradójicamente, una literatura bastante conservadora. $^{191}$

190 CRESPO, Ángel. Los trabajos del espíritu. Diarios (1971-1972/ 1978-1979). Edição de Pilar Gómez Bedate. Barcelona: Editorial Seix Barral, 1999, p. 94-95.

${ }_{191}$ Mis caminos convergentes In Ángel Crespo. Con el tiempo, contra el tiempo. Antonio Piedra e Carlos Martín Aires, coord. Fundación Jorge Guillén et alli, 2005, p. 36. 
Além da proliferação da vertente social ${ }^{192}$, os novos nomes da poesia espanhola na década de 60 - Ángel González, José María Valverde, José Ángel Valente, Francisco Brines, Jaime Gil de Biedma, Claudio Rodriguez, entre outros mantinham-se distantes das vanguardas, constituindo diccções próprias e variadas. A tendência concretista, por exemplo, apenas vingaria na década seguinte.

Por isso, Crespo dedicou uma série de longos ensaios, bem documentados, sobre o concretismo, a poesia práxis e outros grupos. O primeiro deles, "Situación de la poesía concreta", escrito por ele e Pilar Gómez Bedate, saiu no número 5 de junho de 1963, justamente quando Murilo retomava a poesia estimulado pelas palavras de Haroldo de Campos em relação a Tempo espanhol. Depois de detalharem as principais características e representantes, concluem que o movimento foi benéfico à poesia brasileira na medida em que houve o abandono da "exuberância verbal e de um subjetivismo de estirpe romântica". 193 João Cabral é citado mais de uma vez como um dos mais importantes antecessores. Entre os poemas reproduzidos, aparece o "Topogramas", de Haroldo de Campos, escrito em espanhol:

$\begin{array}{lll}\begin{array}{l}\text { 1 sevilla } \\ \text { naranja } \\ \text { sol }\end{array} & \begin{array}{l}2 \\ \text { córdoba } \\ \text { color } \\ \text { olor }\end{array} & \begin{array}{l}\text { granada } \\ \text { torre } \\ \text { león }\end{array} \\ \begin{array}{l}\text { sol } \\ \text { amarillo }\end{array} & \begin{array}{l}\text { olor } \\ \text { córdoba }\end{array} & \begin{array}{l}\text { granada } \\ \text { torreda }\end{array} \\ \begin{array}{l}\text { naranja } \\ \text { amarilla }\end{array} & \text { color } & \text { torre } \\ \text { córdoba } & \text { leonada } \\ \text { amarillo } & \text { córdoba } & \text { león } \\ \text { amarillo } & \text { córdoba } & \text { granada } \\ \text { sevilla } & \text { dolor } & \text { granada } \\ \text { amarilla } & \text { córdoba } & \text { granada }\end{array}$

Como Cabral e Murilo, também Haroldo foi marcado pela "acerada têmpera espanhola”194, mas levando às últimas conseqüências o processo de substantivação

\footnotetext{
192 V. Capítulo 1.

${ }_{193}$ Revista de Cultura Brasileña. n. 5, Madri, jun. 1963, p. 127.

194 Termos do próprio Haroldo de Campos para aproximar a poesia de Cabral e Murilo ("Murilo e o mundo substantivo". Op. cit., p. 71)
} 
da poética de ambos; basta cotejarmos essa série com os três poemas dedicados às cidades andaluzas em Tempo espanhol.

Em número extraordinário de dezembro de 1964, Crespo e Pilar divulgaram uma série de depoimentos de escritores e críticos brasileiros a respeito da literatura de vanguarda. No texto introdutório, "Planteamiento de una encuesta sobre la literatura brasileña de vanguardia", explicam que a literatura na Europa e na América - mais especificamente no Brasil - vivem tempos históricos diferentes: enquanto os europeus, depois dos experimentos de vanguarda, voltam-se ao "realismo", os brasileiros iniciam as experimentações. Mesmo não dispondo de tempo para responder longamente, Murilo enviou uma sintética carta em 23 de julho desse ano, publicada em espanhol no periódico. ${ }^{195}$ Reconhece que "todas as formas e expressões de literatura de vanguarda devem ser estimuladas e reconhecidas", e que "a poesia concreta, a poesia-praxis, apresentaram, tanto na parte teórica, quanto na parte prática, documentos de primeira ordem." Ainda de acordo com o poeta, naquele momento, a vanguarda já era uma tradição que não deveria ser contrária à tradição, mas sim ao academicismo. ${ }^{196}$

Deve-se notar que Murilo mostrou-se atento ao concretismo, procurando acompanhá-lo. Por ocasião do V Salão de Arte Moderna, em 1956, ao comentar os concretistas expostos, chega à literatura:

"Devo dizer que o concretismo ainda não me conquistou totalmente, pois acho fria toda obra de arte desligada de conteúdo afetivo. (...) Eles procuram uma linguagem plástica nova, assim como os músicos que pesquisam relações de som baseadas na escritura atonal, ou como os poetas que buscam a representação da poesia fora ou além do sistema de ordenação da palavra que prevaleceu até agora, dentro duma tradição de lógica e rigor. (Também os poetas de hoje poderiam ser divididos em figurativos, abstracionistas e concretistas)."197

Ainda sob o efeito de Tempo espanhol, perguntavam a Murilo se ele sentia-se "influenciado" pelo concretismo. Assim como ele mesmo afirmava que não era um surrealista, negava uma adesão ao grupo, embora concordasse com a "crise da

\footnotetext{
195 V. Anexos.

196 Revista de Cultura Brasileña. n. 11, Madri, dez. 1964, p. 356.

197 "V Salão Nacional de Arte Moderna: Pintura- I" In GUIMARÃES, Julio Castaón. Op. cit., p. 79.
} 
poesia, por esgotamento dos esquemas". ${ }^{198}$ Talvez essa constatação justifique a sua opção pela prosa, chegando a produzir 8 livros entre 1965 e 1974. No entanto, não se pode esquecer o contato que estabeleceu com os principais nomes e veículos do movimento, a começar por Haroldo de Campos. ${ }^{199}$

Voltando à Revista de Cultura Brasileña, no número 12 de março de 1965, Crespo, juntamente com Dámaso, publicaram sete poemas inéditos de Murilo, no original em português e na tradução em espanhol. Com exceção de um poema de 1959 e um de 1961, o restante data de 1963, ano decisivo para a última produção poética de Murilo.

Na nota preliminar 200 , os dois poetas espanhóis defendem que o "contato com a realidade espanhola", expresso em Tempo espanhol, resultou em um "desejo de concreção, de sobriedade expressiva, de plasticidade não isenta de inquietudes metafísicas". Em consonância com uma tradição crítica que separa a obra muriliana em dois momentos formais distintos, afirmam que o surrealismo dos primeiros livros e o "barroquismo" de Contemplação de Ouro Preto cedem lugar, nesses poemas, a uma "sobriedade expressiva e o rigor de construção".

Cinco poemas versam sobre artistas italianos, evidência do "tempo italiano" que Murilo experimentava. São apresentados "murilogramas" e "grafitos" que formariam seções de Convergência. ${ }^{201}$

Crespo retomou o momento final da poesia de Murilo em nota bibliográfica, estampada no número 16 de março de 1966, sobre Italianissima. 7 Murilogrammi, em edição de Strenna per gli Amici, de Milão. ${ }^{202}$ Menciona que o pequeno volume faz parte de Contacto, um dos nomes do livro que seria publicado em 1970. Insere os poemas nos movimentos de vanguarda aos quais vinha se dedicando, concluindo que sua "intensa corrente humanista" poderia lhes trazer benefícios. Assim como o próprio Murilo, não reconhece apenas o aspecto formal. Não escapa, porém, à comparação com as obras anteriores: “(...) a matéria poética, que em outros livros deste autor permanecia em certo estado de fluidez, se ordena nela de acordo com cânones abertos - no sentido em que é aberto um ideograma (...)". Crespo integrou

\footnotetext{
${ }^{198}$ Entrevista de 1961 (Idem, ibidem, p. 116).

${ }^{199}$ Além da carta citada de 2 de maio de 1963, v. a de julho de 1967 (Idem, ibidem, p. 137-138).

${ }^{200} \mathrm{~V}$. Anexos.

${ }^{201}$ Com algumas alterações no título e no poema, passaram a figurar em Convergência: "Murilograma a Clara Rocha", "Murilograma a Guido Cavalcanti", "Grafito para Giuseppe Capogrossi", "Grafito para Borromini" e "Murilograma a Claudio Monteverdi". "Murilograma a Carla Accardi", em prosa, permaneceu inédito em livro; "Natal 1961", em prosa, integraria o livro inédito Conversa portátil.
} 
Murilo no projeto da Revista de Cultura Brasileña em divulgar a poesia de vanguarda brasileira na Espanha.

\subsection{Gabino-Alejandro Carriedo}

As dedicatórias ou correspondência não aludem ao encontro inicial entre Murilo e Carriedo, mas provavelmente tenha sido contemporâneo ao de Crespo, por volta de 1960. O escasso envio de cartas deu-se de 10 de julho de 1964 à passagem de ano de 1974-1975. ${ }^{203}$ Por elas, sabemos que Murilo leu Política agraria (1963) $)^{204}$ e Los animales vivos $(1965)^{205}$, embora os exemplares não estejam na biblioteca dele. Já Carriedo guardou Tempo espanhol, a tradução italiana de Poesia liberdade, Convergência e Poliedro. ${ }^{206}$

Em carta de fevereiro de 1971, Murilo comunica a Carriedo o envio de seu livro de poesia publicado no ano anterior no Brasil: "Breve receberá meu último Convergência - um dos mais importantes, creio que o mais moderno, dos meus livros. Gostaria muito de - em tempo devido - saber sua opinião." Ainda insiste no PS: "O livro saiu em S. Paulo, e você deverá recebê-lo do editor. Talvez demore um pouco. M."207

A ausência de dedicatória no exemplar de Carriedo confirma que ele recebeuo da Livraria Duas Cidades. O pedido de Murilo surtiu efeito em uma leitura atenta, que deixou vários poemas e versos anotados à caneta vermelha; encontramos, solto no meio das páginas, um pequeno cartão impresso "Homenagem do Autor/ Ausente do Brasil”. Em letra pequena para aproveitar o espaço restrito, com a mesma caneta,

\footnotetext{
202 V. Anexos.

${ }^{203}$ V. Anexos, Correspondência de João Cabral de Melo Neto e Murilo Mendes com escritores espanhóis.

${ }^{204}$ Carta de 10 de julho de 1964 (Arquivo Gabino-Alejandro Carriedo - Fundación Jorge Guillén Valladolid).

${ }^{205}$ Carta de 28 de maio de 1967 (Arquivo Gabino-Alejandro Carriedo - Fundación Jorge Guillén Valladolid).

${ }^{206}$ V. Anexos, Dedicatórias autógrafas em livros.

207 Arquivo Gabino-Alejandro Carriedo - Fundación Jorge Guillén - Valladolid. Em outras correspondências de Murilo, verificamos a importância atribuída a Convergência, como em carta de 10 de fevereiro de 1966 a Drummond, quando ainda se tratavam de dois livros, Contacto e Exercícios, "tentativas de reformulação da minha linguagem poética". (V. GUIMARÃES, Júlio Castañón. Distribuição de papéis: Murilo Mendes escreve a Carlos Drummond de Andrade e a Lúcio Cardoso. Rio de Janeiro: Fundação Casa de Rui Barbosa, 1996, p. 22)
} 
o poeta espanhol esboçou o comentário que talvez tenha mandado, mais elaborado, ao brasileiro:

"Aquí, acaba finalmente con los últimos vestigios de la retórica y, por tanto, alcanza la más amplia, pura y viva expresión. La pura estructura genética, la pura creación (En este libro alcanza...)Véase (197 en adelante) la continuidad con Cassiano, Drummond, Cabral, Braga...La influencia, ¿se nota también de V. Huidobro? // - 199 y 202, inflluencia dos mais jovens: Praxis, noigrandes... // surrealismo (palabras inventadas)"

A observação aproxima-se dos estudos de Crespo na Revista de Cultura Brasileña, que acompanhamos anteriormente. Em "Situación de la poesía concreta", por exemplo, comparecem os poetas citados por Carriedo como pertencentes das "gerações modernistas" que estabelecem um laço de união com o concretismo. ${ }^{208}$ Ainda no mesmo texto, indicam o poeta chileno Vicente Huidobro como antecessor, no contexto hispânico, de uma poesia concreta. ${ }^{209}$

As páginas mencionadas correspondem às últimas do livro, na seção "Sintaxe", a mais anotada, na qual justamente se abandona a sintaxe tradicional.

A partir da década de 70, em sua produção poética, Carriedo incorporou processos morfossintáticos da poesia concreta. Em "Castilla", dedicado a Jorge Guillén, um tema recorrente na obra de Carriedo, sobretudo no período da poesia comprometida $^{210}$, é explorado a partir da semelhança fônica de reduzidas palavras distribuídas no espaço:

$$
\begin{gathered}
\text { Castilla astilla } \\
\text { amarilla } \\
\text { amor de arcilla }
\end{gathered}
$$

Llana dura Ilanura

andadura

honda y dura

\footnotetext{
${ }^{208}$ Os poemas "Gargarín" de Cassiano Ricardo; "paz", de Edgar Braga; "Isso é aquilo", em Lição de coisas, de Drummond (Op. cit., p. 122-123)

${ }^{209}$ "No es difícil rastrar en la poesía de lengua castellana ejemplos que parecen derivar de la experiencia de Mallarmé o que, por lo menos, rompen la estructura gráfica de la página poética en favor de una mayor expresividad de las ideas o sensaciones sugeridas por los versos. Pensamos al escribir esto en el creacionismo del poeta chileno Vicente Huidobro en cuyo poema Ecuatorial (1918), por ejemplo, se emplean tipos de tres cajas diferentes y cuyos versos se distribuyen en la página con muy desiguales sangrías." (Idem, p. 106).

${ }^{210}$ V. Capítulo 1.
} 


$$
\begin{gathered}
\text { Castilla mar de arcilla } \\
\text { Si hembra } \\
\text { siembra } \\
\text { Si cosecha } \\
\text { cosa hecha } \\
\text { Mar de arcilla amarilla } \\
\text { Castilla astilla } \\
\text { canda y dura andura } \\
\text { Ilanura } \\
\text { llana y dura } \\
\text { Castilla } \\
\text { Amor de arcilla hembra } \\
\text { siembra } \\
\text { Si siega dura asegura } \\
\text { cosecha } \\
\text { cosa hecha }
\end{gathered}
$$

Além do convívio da poesia concreta nas páginas da Revista de Cultura Brasileña, a poesia de Carriedo, em Los lados del cubo (1973), parece ter encontrado na obra final de Murilo profícuos estímulos. Um dos melhores elogios que Convergência poderia receber.

\footnotetext{
${ }^{211}$ CARRIEDO, Gabino-Alejandro. Nuevo compuesto descompuesto viejo (Poesía 1948-1979). Op. cit., p. 163.
} 


\section{CAPÍTULO 3: Cabral e as artes de Barcelona}

Os poemas relacionados a pintores e escultores ao longo da obra de Cabral evidenciam o grande interesse que manteve pelas artes plásticas do século $\mathrm{XX}$, no Brasil e no exterior. Significativos da postura do "poeta crítico", surgem desde Pedra do sono, ganhando espaço no receptivo Museu de tudo.

Poucos são os textos críticos a respeito de artes plásticas realizados por Cabral, grande parte destinados a catálogos de exposições, como as promovidas pelo Serviço de Propaganda e Expansão Comercial da Embaixada do Brasil em Madri, na década de $60 .{ }^{212} \mathrm{O}$ primeiro conhecido, "Sobre Segall", publicou-se no número 64 de junho de 1944 da Revista Acadêmica, em homenagem ao pintor. Não comenta nenhuma obra ou técnica, mas sim descreve a impossibilidade de reter na memória a "emoção da contemplação imediata", como teste da "pureza" de um pintor: "Pode-se dizer que a atmosfera de uma obra qualquer, de uma pintura, principalmente, é de natureza literária e vive não pelo que está contido no quadro, mas da realidade de que o quadro é ponto de partida, porta falsa, trampolim. Dizendo de outro modo: não pelo que se vê, mas pelo que se cria, isto é, do que nasce entre o espectador parado diante, sujeito ao tempo e à sua diferença de todos os outros homens, e o quadro, fixo no tempo e na parede." E oferece a lição dessa experiência: “(...) um movimento para fazer voltar às duas dimensões do quadro o principal interesse da pintura; o único e legítimo interesse da pintura."213 Tal princípio para a abordagem das artes plásticas estabeleceria a relação entre o quadro e o poeta Cabral, que em lugar de apenas ver - entenda-se, posicionar-se simplesmente como crítico de arte -, confirmaria ou exploraria princípios de sua poética.

Já Antonio Candido, ao avaliar Pedra do sono quando lançado, reconhece que o poeta, mesmo trabalhando com a matéria onírica, necessitava de um rigor baseado na valorização do vocábulo, centro de gravitação do poema que adquiria um valor plástico. Por isso, vale-se da simbiose entre surrealismo e cubismo para

\footnotetext{
212 Exposição Franz Weissmann (1962), em espanhol sem indicação do tradutor, que depois apareceria em Museu de tudo; Lucy Calenda (1962), em espanhol sem indicação do tradutor, não reproduzido em livro; e Grabados populares del nordeste brasileño (1963), também em espanhol no livro de Angel Crespo, de mesmo título.

${ }^{213}$ SÜSSEKIND, Flora, org. Op. cit., p. 274.
} 
compreender a poética do Cabral estreante: "O seu cubismo de construção é sobrevoado por um senso surrealista da poesia. Nessas duas influências - a do cubismo e a do surrealismo - é que julgo encontrar as fontes da sua poesia. Que tem isso justamente de interessante: engloba em si duas correntes diversas e as funde numa solução bastante pessoal." ${ }^{214}$ Muito mais tarde, Danilo Lobo, em $O$ poema e o quadro: o picturalismo na obra de João Cabral de Melo Neto ${ }^{215}$, estudou, no decorrer da produção cabralina, tanto as referências, como as incorporações das artes plásticas.

No âmbito das artes espanholas, as referências na obra de Cabral não foram tão abundantes quanto as da literatura. $\mathrm{O}$ apreço ao cubismo levou-o a inserir uma "Homenagem a Picasso" em Pedra do sono e um "Juan Gris" em "O sim contra o sim" de Serial.

Por outro lado, em sua estada em Barcelona de 1947 a 1950, envolveu-se intensamente com o ambiente artístico, que vivia um período decisivo de renovação. O florescente mercado de arte atraiu o diplomata, que passou a adquirir quadros. ${ }^{216}$

Uma das figuras centrais foi o crítico e historiador de arte Rafael Santos Torroella, para quem Cabral apresentou a poesia brasileira, possibilitando-Ihe a tradução dos modernistas e de Drummond ao espanhol. ${ }^{217}$ Ele esteve à frente da editora Cobalto, que publicou uma revista especializada em arte, Cobalto. Arte Antiguo y Moderno. Também lançou estudos sobre Salvador Dalí, de Oriol Anguera (1948), e Joan Miró, de Juan-Eduardo Cirlot (1949). Sob o selo Cobalto 49, organizou duas importantes exposições em 1949: Miró e Un aspecto de la joven pintura. Tàpies, Cuixart, Ponç.

Entre várias tendências, irrompia um grande interesse pelo surrealismo. Cabral, depois de seu contato inicial com o movimento nas reproduções trazidas por Vicente do Rego Monteiro no Recife, via-o florescer sob seus olhos, levando-o a novas reflexões. Um exemplo do foco de atenção em Barcelona está no fascículo dedicado ao surrealismo na revista Cobalto. Arte Antiguo y Moderno, de 1948. Cabral também conheceu Juan-Eduardo Cirlot (1916-1973), poeta e crítico de arte

\footnotetext{
${ }^{214}$ CANDIDO, Antonio. "Poesia ao norte" In Op. cit., 139.

${ }^{215}$ Brasília: Thesaurus, 1981.

${ }^{216}$ V. carta a Manuel Bandeira sem data: "Aqui, tenho tido oportunidades fabulosas de comprar algumas pinturinhas." (SÜSSEKIND, Flora, org. Op. cit., p. 70)

${ }_{217}$ Antología de la poesía brasileña. Edição de Renato de Mendonça. Madri: Ediciones Cultura Hispánica, 1952Poemas. “Adonais". Madri: Ed. Rialp, 1951.
} 
muito interessado no surrealismo, que logo integraria Dau al set, grupo herdeiro, entre outros, da vanguarda francesa.

Além da tipografia, auxiliado por Enric Tormo, conviveu tanto com um pintor já consagrado, Joan Miró, quanto com os pintores em início de carreira, Francisco García Vilella, Antonio Tapiès, Modesto Cuixart e Joan Ponç. Essa atividade e relações produziram-se em um momento crucial da obra dele, ocupando o intervalo entre Psicologia da composição e $O$ cão sem plumas. E o Cabral parcimonioso em seus textos críticos realizou um que vale por muitos, o ensaio sobre Miró, cuja complexidade deve ser melhor estudada à luz desse contexto.

\section{0 artesão tipógrafo}

Pouco tempo depois de ter chegado à Barcelona, a tipografia invadia o cotidiano de Cabral. Em carta de 3 de junho de 1947 - aliás, as missivas aos amigos nesse período são o melhor testumunho de suas atividades tipográficas - pedia a Drummond algum texto para ser editado:

(...) Um médido aqui, na verdade, me receitou qualquer ocupação desse tipo, e como não posso quebrar pedra - há uma dignidade consular mínima - a solução teve de ser esta.

Apesar de ser minha estréia na arte, espero que seu livro não ficará feio. Tenho quem me assista e estou disposto a só aproveitar os exemplares perfeitos.(...)

Não falo de outras coisas (...) porque a perspectiva desses trabalhos me está tomando toda a atenção. ${ }^{218}$

O trecho citado contém informações importantes. A recomendação médica refere-se à constante dor de cabeça que atormentava Cabral, que se submeteu a vários tratamentos. A tipografia, antes de mais nada, teria um efeito terapêutico. Mas não pára por aí. O poeta refere-se à "arte", de antiga tradição, que inclusive tomaria, por um momento, o espaço da poesia. A assistência - providencial, diga-se de passagem - veio de Enric Tormo i Freixas. Talvez tenham se conhecido por intermédio de Joan Brossa. Com trabalhos de edição desde o início da década de

${ }^{218}$ SÜSSEKIND, Flora, org. Op. cit., p. 220. 
40, Tormo colaborava com o grupo Dau al set, como no número extraordinário - e belíssimo - de dezembro de 1949: texto de Brossa e ilustrações de Cuixart, Ponç e Tapiès sobre as fotos dos três realizadas por Tormo.

Ele ajudou Cabral a comprar a prensa, uma Minerva, e os instrumentos necessários, instalados em um cômodo do apartamento da rua Muntaner. O reconhecimento chegou com a dedicatória no primeiro livro editado de sua autoria, Psicologia da composição: "A Enric Tormo, Maestro, esta primeira incursão a seus domínios, J. Cabral de Melo Barcelona, 23. XI. 48"

A entrega à confecção dos livros indica os impasses enfrentados na poesia, como desabafa a Clarice Lispector em carta de 8 de dezembro de 1948: "A tipografia continua me absorvendo. Gosto por ela ou fuga do desagradável ato de escrever? Os livros me encantam como objetos e me amedrontam como coisa a escrever."219 Contudo, embora não escrevesse versos, é difícil pensar que o poeta, que vinha pautando sua produção sob o exemplo do engenheiro, da construção, transformado em artesão, não vinculasse essa atividade à poesia. Assim, o cuidado na escolha dos tipos e da sua disposição colocam-no materialmente na situação oposta a da criação aleatória, livre de qualquer rigor. Exigente, nas primeiras tentativas, chegou inclusive a confessar que estragou "não sei quantas folhas sem obter a perfeição desejada."220

Por outro lado, a perfeição não implica sofisticação, pois suas impressões caracterizaram-se pela simplicidade. Embora desse o nome de "O Livro Inconsútil" ao selo, esclareceu que essa "palavra luxuosa esta aí tomada em seu sentido mais material: sem costura."221 Distante da ornamentação, manifestou-se "contra livros e capas ilustrados e, tanto quanto possível, pelo 'livro puro'.,222 No poema dedicado a Tormo, "Paisagem tipográfica", inserido em Paisagens com figuras, desenvolveu as qualidades de uma boa impressão:

Nem como sabe ser seca

Catalunha no Montblanc;

nem é Catalunha Velha

sóbria assim em Camprodón.

\footnotetext{
${ }^{219}$ SOUSA, Carlos Mendes. Op. cit., p. 293.

${ }^{220}$ Carta sem data a Manuel Bandeira (SÜSSEKIND, Flora, org. Op. cit., p. 52)

${ }^{221}$ Carta a Vinicius de Moraes de 16 de setembro de 1949 (Arquivo-Museu de Literatura Brasileira Fundação Casa Rui Barbosa).

${ }^{222}$ Carta a Manuel Bandeira de 5 de novembro de 1947 (SÜSSEKIND, Flora, org. Op. cit., p. 44)
} 

A paisagem tipográfica de Enric Tormo, artesão, é ainda bem mais simples que a horizontal do Ampurdán:
é ainda mais despojada do que a vila de Cervera, compacta, delimitada como bloco na galera. (SA, 133)

A relação explícita entre tipografia e paisagem pode ainda comportar um terceiro termo, a poesia, cuja comparação com ações diversas está presente em outros poemas do mesmo Paisagens com figuras ("Alguns toureiros"). Simples, despojada, compacta e delimitada são atributos também trabalhados na poesia cabralina. Também a identificação com o popular buscada na nova poesia encontraria sua correspondência com a origem humilde da tipografia:

A paisagem tipográfica de Enric Tormo, impressor, é melhor localizada em vistas de arte menor:

na pobre paginação da Tarrasa e Sabadell, nas interlinhas estreitas das cidades do Vallés,

nos bairros industriais com poucas margens em branco da Catalunha fabril composta em negro normando.

Nas vilas em linhas retas feitas a componedor, nas vilas de vida estrita e impressas numa só cor

(e onde às vezes se surpreende igreja fresca e romântica, capitular que não quebra, o branco e preto da página)

foi que achei a qualidade dos livros deste impressor e seu grave ascetismo de operário (não de Dom). (SA, 133-134) 
No verso final, cruzam-se os significados das palavras em relação à tipografia, e por extensão, da poesia: enquanto posição social, o trabalhador manual diferencia-se do tratamento dispensado a reis e príncipes; se pensamos na tarefa em si, o esforço do artífice opõe-se ao presente da dádiva.

A perspectiva social da tipografia foi explorada por Tormo no pequeno texto "Xilografia popular na Catalunha"223, publicado no primeiro e único número da revista $O$ cavalo de todas as cores, em janeiro de 1950. A xilografia pertence a um momento anterior à tipografia, quando as imagens e textos reproduziam-se a partir de pranchas de madeira gravadas em relevo. Tormo identifica, por volta do século $\mathrm{XV}$, um "problema na criação" devido à falta de artistas que produzam originais e à presença estrangeira (Alemanha e Itália), impondo que os gravadores copiem ou se inspirem nas xilografias importadas. Dois séculos mais tarde, no entanto, houve uma volta à gravura popular:

É nela que o verdadeiro gravador se livra do jugo do artista e se converte em seu próprio criador, simplifica sua gramática plástica e com o mínimo de recursos técnicos consegue expressar o poético sentido popular da arte. Há quem, equivocadamente, a tem chamado primitiva. Na verdade é um retorno; as experiências eram demasiado eruditas para resistir à perenidade de sua expressão, para chegar triunfante a este sentido primário e popular da arte.

Por fim, unem-se poesia e imagem em dois planos: uma gravura ilustra uma trova popular em catalão, "El caçador", seguida da indicação "e com ele se funde todo o poético"; e uma gravura com as palavras "Marca del sol" é completada pela observação "e o poético se infunde na indústria". O restante das gravuras reproduzidas também tinham sido aproveitadas nas portadas de "O Livro Inconsútil", duas do século XVIII, para Acontecimento do soneto, de Ledo Ivo, e Sonets de Carnuixa, de Brossa, pentencentes, respectivamente, às coleções de Cabral e de Tormo.

Muito mais tarde, em 1963, depois das experiências de uma poesia mais comunicativa com $O$ rio e Morte e vida e Severina, Cabral retomou o contato com as gravuras populares que acompanham folhetos de poesia popular ao apresentar o catálogo da exposição "Grabados brasileños del nordeste brasileño", em Madri:

${ }^{223}$ V. Anexos. 
(...) tem muito que ver tanto os interessados pela arte popular quanto os apreciadores da xilogravura: os primeiros, porque podem analisar a manifestação contemporânea de um gênero de arte popular que estavam obrigados a estudar em obras dos primeiros séculos da imprensa; e os segundos porque poderão apreciar, em um gênero que parece ter chegado a extremos de gratuidade formalista, como aborda a madeira e resolve seus problemas o artista não refinado, o gravador direto do povo. E também tem muito que ver nestas gravuras as pessoas que, não estando especialmente interessadas pela arte popular ou pela gravura em madeira, estão, simplesmente, pelo problema da expressão. ${ }^{224}$

Cabral considerava os livros impressos como "objetos" de fruição plástica, que caíram nas graças de Joan Miró: “(...) o que diz respeito ao lado plástico da coisa não me desagrada de todo (falo da paginação, da cortada, etc.; coisas que até agradaram francamente o Joan Miró. Aliás, o Miró está entusiasmado com o que se pode fazer em tipografia, e, quando, volte da França, onde foi por um mês, realizaremos alguns trabalhos juntos)."225 $\mathrm{O}$ interesse de Miró pela impressão acompanhou-o durante sua carreira. Para um catálogo seu que seria impresso na França, sugeriu o "máximo de simplicidade e o mínimo de espírito artístico"226, características que encontraria nos livros impressos por Cabral. Trabalhou a maquete de um livro de poemas seus "como se fosse um objeto plástico, pois assim será plástica poética ou poesia plástica". ${ }^{227}$ Ao sonhar com um grande estúdio, revelou que "queria provar a escultura, a cerâmica, ter uma prensa"228. Em 1944 realizou as litografias da série Barcelona, impressas por Tormo.

O editor suíço Gérard Cramer propôs em 1947 a Miró a ilustração de À toute épreuve, livro de poemas de Paul Éluard publicado em 1930. Nas cartas a Crémer, evidencia-se tanto a confluência com as idéias do Cabral tipógrafo, quanto um dos prováveis modelos, o "Livro Inconsútil” do amigo brasileiro: “(...) Fiz provas que me permitiram ver o que é fazer um livro, não ilustrá-lo, a ilustração sempre é algo secundário. O importante é que um livro tenha toda a dignidade de uma escultura

\footnotetext{
${ }^{224}$ MAMEDE, Zila. Op. cit., p. 124.

${ }^{225}$ Carta a Manuel Bandeira de 17 de fevereiro de 1948 (Idem, ibidem, p. 59).

${ }^{226}$ Carta a Pierre Matisse de 16 de novembro de 1936 (MIRÓ, Joan. Escritos y conversaciones. Margit Rowell, ed. Valencia-Murcia: Institut Valencià d'art modern - Colegio Oficial de Aparejados y Arquitectos Técnicos de la Región de Murcia, 2002, p. 193)

${ }^{227}$ Carta a Pierre Matiise de 18 de dezembro de 1936 (Idem, ibidem, p. 196-197)

${ }^{228}$ Texto de 1938 (Idem, ibidem, p. 228)
} 
talhada a mármol"229; "Um livro deve se fazer com a exatidão e a precisão de uma máquina de relojoaria." ${ }^{230}$

Mais uma vez Tormo esteve ao lado de Miró, nas gravuras sobre madeira. A edição somente estaria finalizada em 1958. Durante o longo período de execução, ambos participaram da confecção do ensaio de Cabral sobre Miró. Metade do formato de À toute épreuve, - aproveitando-se inclusive do mesmo papel - a edição de 1950 contou com a realização tipográfica de Tormo e duas xilogravuras coloridas de Miró. ${ }^{231}$

Resta comentar como se posicionou Cabral na escolha dos títulos para sua prensa. Embora recorresse aos amigos, tais relações proporcionaram a divulgação dos clássicos da poesia moderna brasileira na Espanha: Manuel Bandeira, Joaquim Cardozo, Vinícius de Moraes, Murilo Mendes, Cecília Meireles e Carlos Drummond de Andrade. O número de espanhóis foi mais reduzido. Além do amigo Brossa, que se tornaria um clássico da poesia catalã, imprimiu outros três poetas. Juan Ruiz Calonja, depois de sua estréia com Alma a la luna (1948), não prosseguiu na carreira literária. El poeta conmemorativo. Doce sonetos homenaje é apenas um título da vasta obra de Juan-Eduardo Cirlot. Vale a pena deter-se um pouco em Alfonso Pintó (1924). O “inconsútil” Corazón en la tierra (1948) é seu primeiro livro de poemas. Manteve laços com a poesia brasileira ao traduzir a Antología de poetas brasileños de ahora e Cobra Norato e outros poemas (1954), de Raul Bopp, sob o selo Dau al set e vinheta da capa de Miró. ${ }^{232}$ Mereceu Corazón en la tierra uma nota de José Luis Cano no prestigioso periódico Ínsula, em 15 de novembro de 1948:

Tiene este poema de Alfonso Pintó - poema lo bastante extenso para formar un librito - un título muy de postguerra española. Los dos términos que integran corazón, tierra - nos hablan de esa vuelta a los conceptos poéticos elementales un tanto olvidados por la poesía abstracta y deshumanizada de otros tiempos: la poesía llamada pura. Pudièramos decir que este poema de Alfonso Pintó está más cerca de una poesía impura, tomando esta palabra en el sentido que le dio Neruda

\footnotetext{
${ }^{229}$ Carta de 10 de junho de 1948 (Idem, ibidem, p. 299)

${ }^{230}$ Carta de 2 de outubro de 1949 (Idem, ibidem, p. 300)

${ }^{231} \mathrm{~V}$. Anexos, Entrevista com Enric Tormo.

${ }^{232}$ Como esclarece a Nota editorial a essa edição, Pintó ainda traduziu Manuel Bandeira (Manantial. Cuadernos de Poesía y Crítica. Entrega Sexta, Melilla, 1951) e Jorge de Lima, Adalgisa Nery e Cassiano Ricardo (Poesía Española. n. 16. Madrid, abril 1953).
} 
en su revista Caballo verde, es decir, una poesía que arrastra materiales humanos de toda clase, y que hace suyo el dicho de Terencio: Nada de lo humano me es ajeno. Esto es cuanto al fondo, pues en cuanto a la forma, Pintó ha asimilado en su poema las conquistas del surrealismo, y me parece evidente que su técnica se asemeja a la de un libro muy significativo de nuestra mejor poesía surrealista. Aludo a Espadas como labios, de Vicente Aleixandre.

O parecer de Cano justifica as afinidades de Cabral com a obra, pois, nessa altura, defendia que a arte de vanguarda deveria ter um compromisso político ou social. O crítico encerra o seu texto chamando a atenção para o aspecto material do livro, a maioria das vezes não levado em consideração: "Digamos finalmente que la edición es bella, y demos la bienvenida a estas ediciones de El Libro Inconsútil que dirige en Barcelona Joao (sic) Cabral de Melo, que acredita en ellas fino gusto tipográfico y un sentido certero de lo que debe ser la edición poética." 233

\section{O cavalo de todas as cores de Franciso García Vilella}

Ofuscado pela figura de Miró e pelos integrantes do Dau al set, o pintor Francisco García Vilella (1922-2001) não é incluído no elenco das amizades de Cabral com o mundo das artes plásticas em Barcelona. Embora não tenha deixado escritos sobre ele, o diplomata brasileiro reconheceu um grande artista, incentivando-o com suas idéias e propostas.

Cabral e Vilella conheciam-se pelo menos desde 23 de outubro de 1947, data da dedicatória em exemplar de $O$ engenheiro. ${ }^{234}$ Provavelmente Cabral impressionou-se pelas cores vibrantes dos quadros ligados à tauromaquia, como Torero (1946) e La corrida (1947). Logo incumbiu Vilella de um trabalho. Ao que tudo indica, viu-se obrigado a imprimir as traduções de poemas de Baudelaire feitas por Osório Dutra (1889-1968), a fim de agradar o "chefe", o cônsul geral de Barcelona. Dutra ainda cultivava versos ao estilo parnasiano, tendo ganho o prêmio de poesia da Academia Brasileira de Letras em 1929. Para acompanhar a edição, solicitou 11 desenhos a Vilella, como explica em carta a Bandeira de 20 de julho de

\footnotetext{
${ }^{233}$ Ínsula. a. 3, n. 35, Madri, 15 nov. 1948, p. 5.

${ }^{234}$ V. Anexos, Dedicatórias autógrafas em livros.
} 
1948: "(...) quanto ao do Osório é um livro com ilustrações de um pintor daqui, o mais contrário à mentalidade bem-pensante do nosso homem. Foi essa uma molecagem que the armei. Como sabia que teria de publicar um livro dele, arranjeiIhe a camisa de onze varas dessas ilustrações, com as quais, por outro lado, fiz com que esse pintor meu amigo ganhasse algum dinheiro. Sou contra os livros ilustrados, mas o prazer da molecagem me fez esquecer o bom gosto."235

Pelo menos na dedicatória do exemplar de Cores, perfumes e sons oferecido a Vilella, Dutra demonstrou não reparar no descompasso entre ele e as imagens. ${ }^{236} \mathrm{Em}$ formato maior $(28 \times 21 \mathrm{~cm})$ em comparação aos demais de "O Livro Inconsútil" (14 × $21 \mathrm{~cm}$, em geral), cada ilustração ocupa uma folha solta, tornando-se independentes do texto: homens e mulheres de corpos alongados e distorcidos em uma atmosfera fantástica, como em outras composições do pintor, quase todos nus, expressando um erotismo latente. ${ }^{237}$ Segundo Arnau Puig, representam um "punto de transición intermedia entre el desgarro gestual y el dominio de la formalidad anecdótica (...) Un pequeño conflicto entre rabiosa forma íntima y contención por la libertad permitida, que el artista plástico resuelve en un equilibrio formal (...)"238

O ano de 1949 foi movimentado para Vilella. Além de três exposições, estampou-se um desenho seu de feição surrealista no número de julho-agostosetembro de Dau al set, no qual também saíram as traduções dos poemas de Cabral por Brossa. Apesar dessa concessão ao grupo de vanguarda, a obra de Vilella mantinha características próprias, como ressaltou Sebastià Gasch por ocasião da presença do pintor no II Ciclo Experimental de Arte Nova, desse ano: “(...) tras el cubismo que degeneró en decorativismo, tras el surrealismo que ha caído en la ilustración, pertenece a la generación de la angustia y de la amargura, es un reflejo del clima desolado y amargo de la posguerra." ${ }^{239}$ Acrescenta que Vilella possui duas "qualidades ibéricas" que o impedem de cair na abstração ou na literatura: a preferência pelo humano e o contato com a terra, mesmo que a fantasia e a imaginação tenham papel importante em sua obra. Tais características

\footnotetext{
${ }^{235}$ SÜSSEKIND, Flora, org. Op. cit., p. 87.

236 "Ao jovem e magnífico artista García Vilella, que com tanta inspiração e tanta inteligência ilustrou estas traduções de Baudelaire oferece Osorio Dutra Barcelona, 13-7-948" (Acervo particular de Francisco García Vilella).

${ }^{237} \mathrm{~V}$. Anexos, Imagens.

${ }^{238}$ García Vilella. Las raíces de un artista de la modernidad In PUIG, Arnau, FORNS, Manuel PérezLizano e HERRADOR I RODRIGUES, Juan Ramon. García Vilella. Barcelona: Ámbit, 2004, p. 161.
} 
"ibéricas" impressionaram Cabral, que também as havia identificado na poesia espanhola. No entanto, assim como fez com os participantes de Dau al Set, discutiu idéias marxistas com Vilella, que passou a se preocupar com a mensagem social de sua pintura. A leitura de $O$ cão sem plumas, oferecido por Cabral em agosto de $1950^{240}$, talvez tenha contribuído à reflexão de Vilella. Suas telas desse momento incorporam os protestos operários e a repressão franquista, como "La vaga de tramvies" (A greve dos bondes), de 1951, no qual, sem abandonar a técnica moderna, representa o dramático embate entre os manifestantes e a polícia ocorrido em Barcelona.

Cabral também pediu a colaboração de Vilella para ilustrar a capa do único número de $O$ cavalo de todas as cores, de 1950; o preto do cavalo oculta todas as cores, mas mostra um aspecto fantástico: asas, chifre, garras e uma espécie de labareda solta pela boca. Poeta e pintor ainda se cruzaram no volume Em va fer Joan Brossa, de 1951: Cabral assinou o prefácio e Vilella desenhou o símbolo da coleção de poesia "La calle desierta", dirigida por Rafael Santos Torroella.

\section{Joan Miró: o "sólido artesão da Catalunha"}

Depois de nove meses em Nova lorque, Miró retornou a Barcelona em outubro de 1947, permanecendo ali até sua mudança a Palma de Mallorca em 1956. Segundo Cabral, o primeiro contato surgiu de uma encomenda de um quadro para um primo, José Carneiro Leão, por intermédio do pintor Ramón Rogent. ${ }^{241}$ Logo se tornaram amigos: Miró, já reconhecido internacionalmente, no restrito círculo de apreciadores de arte moderna da Barcelona daquele momento, pôde identificar um interlocutor no jovem poeta diplomata. A poesia também foi um ponto em comum entre os dois. Além de ter convivido com poetas em suas estadas parisienses, Miró, assíduo leitor, foi "poeta bissexto". ${ }^{242}$ Chegou a emprestar a Cabral Paroles, de Jacques Prévert. ${ }^{243}$

\footnotetext{
${ }^{239}$ Idem, ibidem, p. 139.

${ }^{240} \mathrm{~V}$. Anexos, Dedicatórias autógrafas em livros.

241 Entrevista de 1993 (ATHAYDE, Félix de, org. Op. cit., p. 131).

242 V. "18. Un cuaderno de poemas, 1936-1939", "19. Poema, 1937", "41. Poema, 1960" e "49. Poemas, 1972 y 1976" em MIRÓ, Joan. Op. cit. Desenvolvemos as relações de Miró com a poesia no Capítulo 4.

${ }^{243}$ Carta a Bandeira de 3 de dezembro de 1949 (SÚSSEKIND, Flora, org. Op. cit., p. 114)
} 
O encontro deu-se em etapas cruciais das trajetórias de Miró e de Cabral. O convulso período da Guerra Civil Espanhola e da Segunda Guerra Mundial interferira no trabalho de Miró. Nesses anos de intensa reflexão, não pintou quadros, mas praticou no desenho formas, traços e signos que constituiriam sua futura iconografia. Voltando a pintar em 1944, consolidou sua linguagem pictórica por volta de 1946. Realizou 15 pinturas somente do final de 1947 ao começo de 1948, quando Cabral seguramente já freqüentava seu ateliê. Entre 1949 e 1950, as atividades, além de mais de 50 pinturas, incluíam desenhos, esculturas, estampas, livros, etc. Cabral teve o privilégio de acompanhar de perto essa efervescência da maturidade de Miró. Também atraiu-se pelos variados objetos que o artista colecionava para aproveitar em suas obras: “(...) Atualmente, esse problema da possibilidade de expressão pessoal numa seleção me obceca. Ainda há pouco tempo, reconheci toda a pintura de Miró, ou melhor, seu mundo, num pequeno museu que ele tem em casa, e onde agrupa desde esculturas populares até pedras achadas ao acaso na praia, pedaços de ferro-velho com uma ferrugem especial etc. É impressionante como tudo aquilo é Miró. ${ }^{244}$ Em sua obra posterior, também promoveria uma apurada "seleção" de palavras, de temas, chegando mesmo a formar um Museu de tudo.

Enquanto isso, terminara Psicologia da composição, atingindo um ponto extremo no processo de construção e reflexão da poesia, como detalhou em carta a Clarice Lispector:

(...) De certo modo é este o primeiro livro que consigo fazer com alguma honestidade para com minhas idéias sobre poesia. É um livro construidíssimo; não só no sentido comum, i. é, no sentido que trabalhei muitíssimo nele, como num outro sentido também, mais importante para mim: é um livro que nasceu de fora para dentro. Quero dizer: a construção não é nele a modelagem de uma substância que eu antes expeli, i. é, não é um trabalho posterior ao material, como correntemente; mas pelo contrário é a própria determinante do material. Quero dizer que primeiro os planejei, abstratamente, procurando depois, nos dicionários, aqui e ali, com que encher tal esboço. O que eu fiz me lembra aquela máquina que há nas ruas do Rio, que serve para fazer algodão de açúcar. Você a olha, no começo e só vê uma roda girando, depois, uma tênue nuvem de açúcar se vai concretizando em torno da roda e termina por ser algodão. A imagem me serve

${ }^{244}$ Carta a Bandeira de 17 de fevereiro de 1948 (Idem, ibidem, p. 60) 
para dizer isso: que primeiro a roda, i. é, o trabalho de construção; o material - que é a inspiração, o soprado pelo Espírito Santo, o humano, etc. - vem depois: é menos importante e apenas existe para que o outro não fique rodando no vazio (prazer individual, mas sem justificação social, imprescindível numa arte que lida com coisa essencialmente social, como a palavra). ${ }^{245}$

O intelectualismo de Cabral isolava-o em relação à tradição lírica lusobrasileira. Embora tivesse descoberto a poesia espanhola, seus efeitos mais diretos somente se fariam notar em sua obra a partir da década de 50 , mais precisamente com $O$ rio. Dessa maneira, experimentou o impasse em prosseguir uma poesia que privilegiasse o "construir" em lugar do "humano", ou ainda, da "justificação social", a qual, nesses anos, cada vez mais o preocuparia, levando a uma situação de comprometimento. Por outro lado, corria-se o risco de haver encontrado uma "fórmula". Faltava-Ihe, portanto, um referencial para questões que a literatura ainda não era capaz de solucionar integralmente. A pintura de Miró, ao trabalhar tanto com cores e formas, quanto com os mais variados materiais, apresentou-se a Cabral como um campo ideal para refletir sua própria poesia. Nada melhor do que se voltar ao um "tão unicamente pintor, ou pintor tão pouco literário" (P, 41).

Paralelamente à tipografia, Cabral interessava-se muito pelo processo de construção artística, não como algo espontâneo e gratuito ou sujeito a leis prévias, mas fruto de um árduo trabalho, identificando-o, mais de uma vez, com a figura do artesão. Na mesma carta que descreve a Bandeira o ateliê de Miró, sugere ao amigo uma "confissão" de seu modo de escrever poesia com o objetivo de "fazer nossos melhores poetas falarem de si mesmo em termos artesanais" para uma revista que não chegou a editar. ${ }^{246}$ No entanto, testemunhou o processo de elaboração de uma obra de arte. Em lugar de colher um depoimento, ele resolveu compor um texto analisando como um pintor faz seus quadros. Sob esse ponto de vista, Joan Miró pode ser tomado como desenvovimento de Psicologia da composição, cuja discussão prosseguiria na palestra "Poesia e composição: a inspiração e o trabalho de arte", de 1952; inclusive um dos segmentos do livro de 1950 intitula-se "Psicologia da sua composição".

\footnotetext{
${ }^{245}$ SOUSA, Carlos de Mendes. Op. cit., p. 291.

${ }^{246}$ SÜSSEKIND, Flora, org. Op. cit, p. 61.
} 
A própria execução foi árdua, verdadeira "gestação" ao consumir 9 meses, de outubro de 1948 a junho de 1949. Desde o começo enfrentou desafios: "Atualmente me preocupa mais um estudo sobre Miró, que estou escrevendo... com ódio. Com ódio pela prosa e pela técnica da crítica." ${ }^{247}$ Em carta de 8 de dezembro de 1948 a Clarice Lispector, desabafa: "Há uns dois meses comecei como um leão um pequeno livro sobre o pintor Miró, hoje arrinconado num lugar qualquer e do qual procuro me esquecer." 248 Por fim, encerrou-o esgotado: "Terminei, afinal!, o meu ensaio sobre Miró e ele me preocupou tanto que os dois meses que seguiram ao ponto final foram para mim meses de vazio. Sentia-me chupado." ${ }^{249}$ Mas a opinião favorável de Miró compensou-o do esforço, pois o pintor recebeu com "absoluta indiferença" livros franceses e espanhóis publicados sobre ele naqueles anos, entre os quais o de Juan-Eduardo Cirlot de 1949. Infelizmente o ensaio de Cabral, na Espanha, é mais reconhecido pelas litografias de Miró, não tendo merecido até hoje uma tradução.

Dividido em duas partes - "técnica" e "psicológica"250 - , com um P.S. ao final, o texto é extremamente organizado e didático: cada parte encontra-se subdividida, respectivamente, em 21 e 17 segmentos, cujos títulos aparecem à margem, como as indicações de "Fábula de Anfion". A proximidade dos assuntos ainda propõe mais uma organização, ao se dar um espaço entre três séries de segmentos de capa parte. Assim, podemos apresentar a estrutura do livro:

I-

"As pinturas pré-Renascentistas", "A criação da pintura", "Terceira dimensão e estatismo", "Compor como equilibrar", "Mais sobre o equilíbrio", "O estatismo como estilo" (1 $1^{a}$ série) "Miró contra a pintura", "Miró e seus contemporâneos", "Sua história: abandono da terceira dimensão", "Sua história: uma composição descontínua", "Sua história: ainda o descontínuo", "Sua história: o objeto e a moldura", "Sua história: o falso dinamismo ( $2^{a}$ série) "Miró não-gramatical", "Miró anti-gramatical", "Aparece o dinamismo", "O que é o dinamismo de Miró", "Importância da linha", "A linha na estrutura estática", "A linha na pintura de Miró", "O segredo de sua linha" ( $3^{\mathrm{a}}$ série)

${ }^{247}$ Carta a Drummond de 9 de outubro de 1948 (Idem, ibidem, p. 228)

${ }^{248}$ SOUSA, Carlos Mendes. Op. cit., p. 293.

${ }^{249}$ Carta a Bandeira de 15 de setembro de 1949 (SÜSSEKIND, Flora, org. Op. cit., p. 228) 
"Quando a estrutura foi pesquisa", "Quando a estrutura foi gramática", "Quando estrutura é instinto", "A estrutura inalterável", "Porquê da estrutura inalterável" ( $1^{\text {a }}$ série)

"Psicologia de sua composição", "O gosto pelo fazer", "O fazer como ponto de partida" (2a série)

"Miró e o Surrealismo", "Entendimento do Surrealismo", "Ainda o Surrealismo", "Continua a psicologia de sua composição", "Intelectualismo de Miró", "Ainda seu intelectualismo", "Um rigor sempre mais agudo", "Criar como inventar" ( $3^{\mathrm{a}}$ série)

Apenas por esse roteiro, impressiona a precisão e a desenvoltura de um Cabral que praticamente não se expressou em textos de crítica de arte. Além disso, tirou proveito da convivência com Miró, pois aqui e ali podemos descobrir as idéias do pintor oportunamente incorporadas.

$\mathrm{Na}$ parte I, o que denominamos de "1ª série", trata-se de uma introdução que contextualiza a obra de Miró na arte ocidental, cujo marco é o Renascimento, ao fixar as leis da pintura. Vale-se da pré-história e da arte românica para exemplificar que o objeto representado estava "solto no espaço", não limitado pela superfìcie. Miró, como será demonstrado no decorrer do ensaio, recuperou a liberdade da figura na tela, tendo reconhecido em várias ocasiões aquelas manifestações como ideais: "Minhas escolas de pintura favoritas são as mais distantes no tempo quanto for possível: os pintores rupestres, os primitivos. $\mathrm{O}$ Renascimento não tem o mesmo interesse para mim". ${ }^{251}$ Um pouco mais tarde, será a vez de Cabral buscar na poesia espanhola anterior ao século XVI o redirecionamento de sua poética. ${ }^{252}$

Como princípio norteador da pintura a partir do Renascimento impõe-se a ilusão da profundidade do ambiente em que o objeto se localiza, a "terceira dimensão", condicionando que o espectador fixe seu olhar em um ponto. "Estatismo" e "dinamismo" são termos contrários que conduzem a tese da primeira parte do texto. Da situação de "estatismo" derivou a noção de "equilíbrio" que constitui a beleza da obra de arte. Cabral introduz a primeira menção à literatura com Baudelaire, poeta e também crítico de arte, o qual, dando início à modernidade na poesia, procurou subverter esse conceito de beleza. Como não

\footnotetext{
${ }^{250}$ Termos de Cabral em carta a Bandeira de 15 de setembro de 1949 (Idem, ibidem, p. 104).

251 Entrevista de 1947-1948 (MIRÓ, Joan. Op. cit., p. 288).

${ }^{252}$ V. Capítulo 1.
} 
podemos nos esquecer que antes de mais nada é um poeta que está escrevendo sobre pintura, é provável que em suas considerações já estivesse pensando na poesia da Geração de 45, julgadas posteriormente na série de artigos de 1952: “(...) marcada pelo desejo de construir um tipo de universo que, depurado da realidade, habitasse uma dimensão de serenidade e afastamento do ambiente. Idéia de beleza que ainda é nossa, embora já não seja a nossa (e por isso, à palavra beleza preferimos poesia - com seu sentido extraído não sei que perturbadora atmosfera metafísica)." (P, 21). Na $2^{a}$ série da Parte I, percorre-se a trajetória de Miró em busca do "dinamismo" perdido pela pintura, "sua história", ao realizar o caminho contrário feito até à conquista da terceira dimensão. Como primeiro passo, o abandono da ilusão da profundidade e da exigência do centro do quadro implica na perda da "hierarquização de elementos": "À idéia da subordinação de elementos a um ponto de interesse, ele substitui um tipo de composição em que todos os elementos merecem igual destaque. Nesse tipo de composição não há um elemento dominante, mas uma série de dominantes, que se propõem simultaneamente, pedindo do espectador uma série de fixações sucessivas, em cada uma das quais lhe é dado um setor do quadro." ( $P, 24)$. Se substituirmos as palavras "espectador" e "quadro" respectivamente por "leitor" e "poema", poderíamos transferir essa passagem para a fortuna crítica da obra cabralina. Interrompido pelo discurso narrativo de $O$ rio e Morte e vida Severina, desde "Psicologia da composição" e "Antiode" verificamos o predôminio de uma "série de dominantes", ou melhor, do longo poema dividido em "setores" identificados geralmente por números ou letras. A bailarina de flamenco ou a cabra, por exemplo, não são vistos em função de um "elemento dominante", mas sim por imagens a princípio desconexas do tema, o qual, para ser reconstituído, requer que o leitor as acompanhe. Assim como Miró conseguiu "quadros inscritos num quadro", Cabral obteve "poemas inscritos no poema"; ambos desintegraram a unidade do quadro e do poema, conquistando um "dinamismo" sem perder o controle da composição. ${ }^{253}$

\footnotetext{
${ }^{253}$ Recentemente, Alfredo Bosi, no ensaio "Fora sem dentro? Em torno de um poema de João Cabral de Melo Neto" - uma das mais pertinentes análises das possíveis relações entre o texto crítico e a prática poética - ao se deter na figura do cassaco em "Na festa da casa-grande" de Dois parlamentos, apresenta um procedimento que o poeta pode ter aprendido do pintor: "O efeito de unidade figural, da Gestalt, na acepção de coerência dos significantes, será construído paulatinamente pelo olho do leitor atento às partes consecutivas, às vezes parecidas entre si, às vezes contrastantes, pois a estrutura da superfície não é dada como uma totalidade redonda que o
} 
Na Parte II de Joan Miró, Cabral explora a tese do artista consciente, "fabricante", que ia ao encontro das suas aspirações poéticas. Como realizara em Psicologia da composição, o pintor também "valorizava o fazer": “(...), o quadro, para Miró, é um pretexto para o fazer. Miró não pinta quadros. Miró pinta." $(P, 39)$. No segmento já mencionado, "Psicologia da sua composição", ponto nevrálgico do ensaio, a atitude de Miró é considerada como "psicológica": "(...) luta permanente, no trabalho do pintor, para limpar seu olho do visto e sua mão do automático. Para colocar-se numa situação de pureza e liberdade diante do hábito e da habilidade." $(\mathrm{P}, 38)$.

Para reforçar ainda mais seu ponto de vista dedica três segmentos ( $3^{\mathrm{a}}$ série) para avaliar a posição de Miró frente ao Surrealismo. O próprio Miró se insurgiu contra uma etiqueta de "surrealista": "(...) Mas eu, antes de tudo e sobretudo, quero conservar minha independência rigorosa, absoluta, total. Observo que o surrealismo é uma manifestação sumamente interessante do espírito, um valor positivo; mas não quero seguir suas rigorosas disciplinas. ${ }^{254}$ Interessante notar que mesmo a pintura automática, ou seja, tudo o que se constituía um princípio artístico, parecia-Ihe uma "rigorosa disciplina". Quanto a Cabral, a insistência no surrealismo - um dos segmentos intitula-se "Ainda o Surrealismo" - não é meramente analítica; outra vez serve-se do pintor para poder falar do poeta. Como Miró, provavelmente reconhecia sua importância de revelar um "fundo existente no homem por debaixo da crosta de hábitos sociais adquiridos, onde eles localizavam o mais puro e pessoal da personalidade." ( $P, 40-41)$. Por outro lado, Miró e Cabral não se entregaram à pintura ou à escrita automática, totalmente divergentes em relação à lucidez da invenção. Cabral assim encerrava suas dívidas para com o surrealismo. Um de seus últimos vestígios viria em $O$ cão sem plumas, onde aparece uma pictórica "mulher febril que habita as ostras", da qual "seguramente" sabia o rio.

A correlação pintura-poesia aflora no segmento "Um rigor sempre mais agudo", espécie de meta: “(...) Não há, como no trabalho de certos poetas, o equivalente daquela primeira palavra, fecunda de associações e desenvolvimentos, que contém em si todo o poema. A luta, aqui, se dá na passagem de uma a outra palavra e se uma dessas palavras conduz a uma outra, em lugar de aceitá-la em

olho possa abarcar de relance, do centro à margem. A razão interna do texto é serial, fabricante de micro-estruturas novas, pontuais. É assim que o dentro olha para fora." (Estudos Avançados. v. 18, n. 50, São Paulo, 2004, p. 202. Agradeço a Arlindo Rebechi Junior a indicação desse texto).

${ }^{254}$ Entrevista de 1931 (Idem, ibidem, p. 176) 
nome do impulso que a trouxe, essa consciência lúcida a julga, e ainda com mais rigor, precisamente por sua origem obuscura." $(P, 45)$. Finalmente o poeta trai $o$ crítico de arte: Cabral deixa por um momento Miró para defender sua poesia.

O texto termina com uma questão em aberto: "A descoberta desse território livre, onde a vida é instável e difícil, onde o direito de permanecer um minuto tem de ser duramente conseguido e essa permanência continuamente assegurada, não tem uma importância psicológica em si, independente do que no campo da arte ela pudesse ter produzido?" $(P, 47)$. Para sua situação, Cabral logo responderia que não, já que lhe faltava também o "tema dos homens".

No P.S., conclusão que se revela como ponto de partida para os novos rumos da poesia cabralina, remonta à primeira fase da pintura mironiana, mais figurativa, cuja simplificação gradativa justificaria a luta do pintor por se libertar de todo um sistema: “(....) Explica, por exemplo, porque este homem, em cujos começos se notava tão grande amor à realidade, e em quem se nota, ainda hoje, tão desmedido amor por esse outro tipo de realidade - os materiais humildes de sua arte, dos quais sempre parte - foi levado a um ponto extremo de estilização, de abstração." (P, 48). Procura, assim, descartar a vinculação de Miró com a arte abstrata: "De certa maneira, se pode dizer que o abstrato está nos dois pólos do trabalho de representação da realidade. É abstrato o que apenas se balbucia, aquilo a que não se chega a dar forma, e abstrato o que se elabora ao infinito, aquilo a que se chega a elaborar tão absolutamente que a realidade que podia conter se faz transparente e desaparece. No primeiro caso, a figura é abstrata por ininteligível; no segundo, por disfarçada. No primeiro, se permanece aquém da realidade; no segundo, se nega a realidade. " $(P, 48)$.

A luta de Miró em resgatar uma nova dinâmica para o quadro salvaria sua obra de ser considerada um formalismo a mais. Ao compartilhar com o pintor a aversão ao automatismo surrealista e o abstracionismo, Cabral estaria chegando no cerne da sua poética da maturidade: o trabalho artístico aliado à perspectiva humana. A respeito de suas objeções em relação ao formalismo, é importante retomar o prólogo ao livro Em va fer Joan Brossa (1951), no qual se apóia nos paralelos entre literatura e pintura: "O fato primordial é saber que objeto se vai pintar, que objeto é digno de se pintar." Para explicar que o "tema dos homens" não é uma questão de forma mas de assunto, recorre ao exemplo de uma maçã em uma bandeja pintada academicamente, apresentando-o na mesma condição da 
pintura abstrata: "Da maçã aos simples círculos amarelos e vermelhos de um quadro abstrato, o ponto é mínimo. Vai ser o abandono da dignidade, ou seja, da importância humana (para os homens) dos assuntos, o longo caminho que vai fazer desembocar os artistas em uma arte que nega radicalmente o assunto. De fato, a importância, para os homens, de um quadro com uma bandeja de maçãs e de um quadro com círculos de cor é absolutamente a mesma. Em certo sentido, quando a pintura vai descender até a natureza morta, ao nu, à paisagem de tabique, vai começar a se tornar abstrata."

Ainda nesse 1951, em resposta a uma carta em que Bandeira queixava-se de estar velho para compreender o abstracionismo nas artes plásticas, manifestou-se contrário a essa corrente:

(...) Mas você com sua autoridade podia muito bem tomar a frente de um movimento de denúncia do abstracionismo em pintura, de seu equivalente atonalismo em música e do neoparnasianismo-esteticismo da Geração de 45. Eu namorei essas coisas quando estive no Brasil. E quando vim para a Europa compreendi o que havia por debaixo de tudo isso e o trágico que é para nós brasileiros nos entregarmos a todos esses requintes intelectuais. Porque da Europa é que pude descobrir como o Brasil é pobre e miserável. Isto é: depois de ver o que é a miséria européia - enorme da Espanha, Portugal, dura na França, na Inglaterra acho que é preciso inventar outra palavra para a nossa, cem vezes mais forte.

Por tudo isso ser abstrato é trágico e ridículo para um brasileiro. ${ }^{255}$

Em Psicologia da composição, atingira, usando as mesmas palavras ao se referir a Miró, um "ponto extremo de estilização, de abstração". Para Miró, "seguro de sua mecânica", não havia necessidade de retornar a um "assunto e uma pintura mais largamente humana". Mas Cabral ainda não estava totalmente "seguro de sua mecânica". Os ensinamentos do pintor chegariam também por outra perspectiva, não apenas da pintura, mas também a da paisagem. Vale lembrar que os dois vinculavam-se a determinadas regiões de seus países, Catalunha e Nordeste. Miró, da capital Barcelona, preferiu a paisagem rural de Montroig, na província de Tarragona. Este pode ter sido o início da volta de Cabral à capital Recife e ao interior de Pernambuco.

${ }^{255}$ SUSSEKIND, Flora, org. Op. cit., p. 145-146. 
Muitas vezes o pernambucano acompanhou o catalão em sua propriedade de Montroig. Nas notas de trabalho de 1940-1941, o pintor descreve a mudança de sua pintura a partir do lugar do qual via a paisagem:

ao vir de novo a Montroig e fazer uma revisão de minha obra, esta me pareceu uma coisa muito forte e filha deste lugar. Ao ver a paisagem da masía ${ }^{256}$, com estes planos tão grandiosamente simples, me dá a razão de muitos de meus trabalhos, simples, grandiosos e brutais; (...) Ao contrário, subindo à ermita de La Roca e ver as imensidades de terreno com oliveiras, árvores, charcos redondos e quadrados, a terra lavrada, toda esta riqueza de detalhes me coloca em cheio em minhas realizações atuais; o que faz vinte anos eu amava e previa sem chegar a plasmar, o faço agora. ${ }^{257}$

A simplificação da paisagem e dos objetos já era obtida pela distância da qual a contemplava, com a perda dos detalhes. A experiência reveladora da altura seria retomada por Cabral no poema "Campo de Tarragona", de Paisagens com figuras:

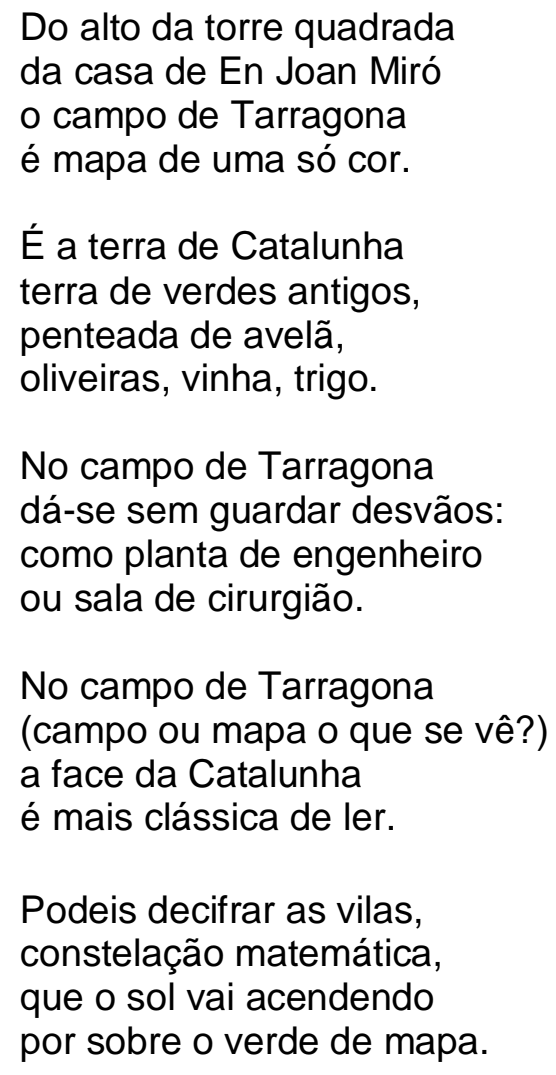

${ }_{256}$ Casa de campo na Catalunha.
257 MIRÓ, Joan. Op. cit., p. 260. 
Podeis lê-las na planície como em carta geográfica, com seus volumes que ao sol, têm agudeza de lâmina,

podeis vê-las, recortadas, com as torres oitavadas de suas igrejas pardas, igrejas, mas calculadas. (...)

Cabral investe por uma paisagem "cultivada", podendo ser lida à maneia de um mapa. Paisagem "sem mistérios", na qual as vilas mostram-se como "constelação matemática" e as igrejas, "calculadas", aproximando-se das pinturas detalhistas do primeiro Miró: Mont-roig, a igreja e o povoado, de $1919^{258}$, pode ser um bom exemplo, ao revelar em um primeiro plano os campos lavrados - contando inclusive com um trabalhador - e ao fundo, as construções.

Porém, quando se passa ao seu contraponto pernambucano, do "Alto do Trapuá" avista-se uma paisagem totalmente distinta, longe de ser "clássica":

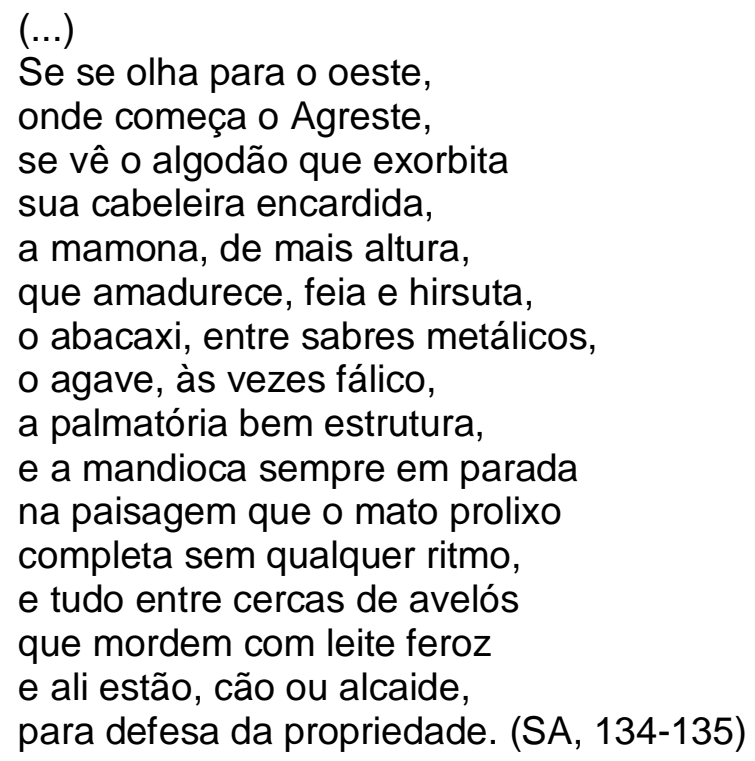

Enfim, o olhar se depara com o homem da região; o que na pintura de Miró se recortava nítido na força do trabalho, no poema de Cabral confude-se com as outras espécies vegetais: 


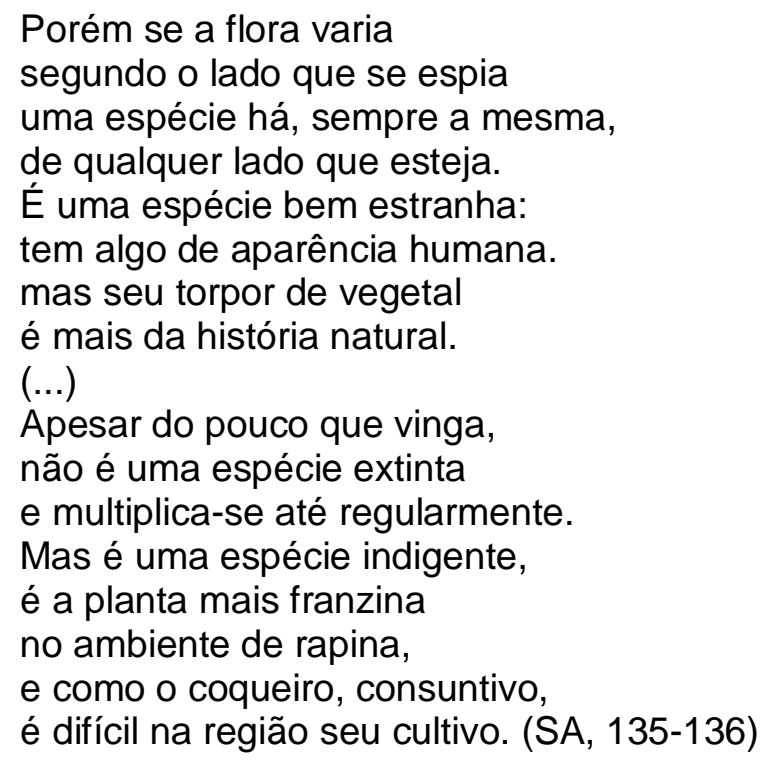

O poeta, nessa altura, já saíra da ameaça de um excesso de intelectualismo, tendo incorporado o drama da miséria humana.

Mas o olhar do pintor e do poeta abarcariam paragens mais altas. Em entrevista de 1959, Miró disse gostar do "mundo visto de um avião": "Devo uma das maiores emoções de minha vida ao sobrevoar Washington, de noite. Vista de um avião, de noite, a cidade é uma maravilha. E depois, de um avião se vê tudo. Um pequeno personagem, inclusive um cachorro muito pequeno, se vê. $E$ isso adquire uma importância enorme, como uma ou duas luzes de campesinos numa escuridão absoluta, durante um vôo noturno por cima do campo."259 Para dois artistas que estiveram em grande sintônia são permetidas as coincidências. Nesse 1959, Cabral terminava Quaderna que contém o poema "De um avião", de fortes sugestões pictóricas. Conforme ultrapassa os círculos da distância da terra, percebe-se a conhecida paisagem recifense como pintura de vanguarda:

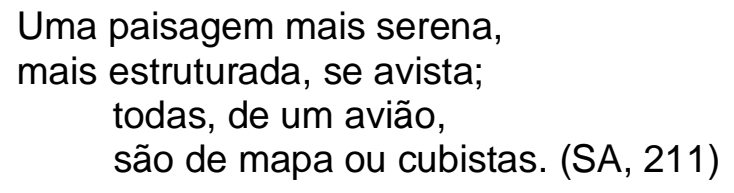

Em "O sim contra o sim" de Serial, a pintura cubista do espanhol Juan Gris também é vista pela distância de uma "lente avião":

${ }^{258} \mathrm{~V}$. Anexos, Imagens. 
Juan Gris levava uma luneta por debaixo do olho: uma lente de alcance que usava porém do lado outro.

As lentes foram construídas para aproximar as coisas, mas a dele as recuava

à altura de um avião que voa.

Na lente avião, sobrevoava, o atelier, a mesa, organizando as frutas

irreconciliáveis na fruteira.

Da lente avião é que podia pintar sua natureza: com o azul da distância

que a faz mais simples e coesa. (SA, 290)

Como em "Alto do Trapuá", somente a distância poderia dar a ilusão de aparência de homem, sem ver de perto sua degradante situação:

Se daqui se visse seu homem, homem mesmo pareceria:

mas ele é o primeiro que a distância eneblina

para não corromper, decerto, o texto sempre mais idílico que o avião dá a ler de um a outro círculo. (SA, 211)

$\mathrm{Na}$ "Festa da casa-grande" de Dois parlamentos, o recurso do "longe" e do "perto" para configurar o contraste à figura humana e sua condição social também comparece: "- O cassaco de engenho/ de longe é como gente:/ - De perto é que se vê/ o que há de diferente." (SA, 267). ${ }^{260}$

Mais alto ainda, a paisagem simplifica-se, aproximando-se das pinturas de Miró:

\footnotetext{
${ }^{259}$ Idem, ibdem, p. 335.

${ }^{260}$ Alfredo Bosi aproxima esse procedimento à pintura de Miró: "Como um pintor que renunciou à perspectiva clássica, João Cabral olha e nomeia ora de longe, ora de perto, o seu cassaco de engenho. Vai dispondo no branco da página as figuras-palavras e as diz sucessivamente, exigindo do leitor o mesmo movimento dos olhos com que as luas e as estrelas do pintor catalão atraem o seu espectador." (Fora sem dentro? Em torno de um poema de João Cabral de Melo Neto. Op. cit., p. 201).
} 


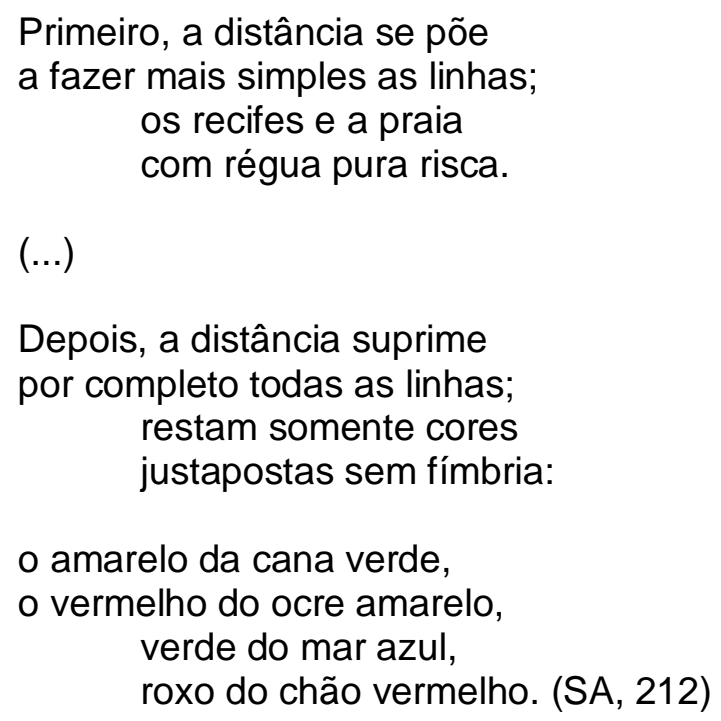

\section{Tapiès, Cuixart, Ponç}

Ao se abordar as trajetórias de Antonio Tapiès, Modesto Cuixart e Joan Ponç no final dos anos 40, é inevitável que estejam vinculadas ao nome de João Cabral de Melo Neto. Em diversas ocasiões, eles próprios e seus críticos assinalaram o fecundo encontro com o poeta diplomata. Mas antes disso, havia a forte ascendência de Brossa, que os "inclinava excessivamente em direção às imagens literárias"261, chegando a atribuir títulos aos quadros deles.

Cabral escreveu um texto para o primeiro fascículo de Cobato $49^{262}$, por motivo da exposição Un aspecto de la joven pintura. Tapiès, Cuixart, Ponç, que teve lugar no Instituto Francês de Barcelona, de 17 de dezembro de 1949 a 3 de janeiro de 1950. No início, retoma o ensaio sobre Joan Miró, referência fundamental para esses pintores. Assim, eles coincidiam em compor independentemente do estatismo tradicional. No entanto, o "estato de espírito" na luta por essa liberdade é diferente para os três, a partir da relação que estabelecem com o limite da superfície do quadro. Aproveitando a expressão cara ao poeta nesse instante, estaríamos diante de três "psicologias da composição". Do "grande artesão" Miró, Cabral passou para os jovens artistas que como ele buscavam uma linguagem própria. Mais do que avaliar as obras de Tapiès, Cuixart e Ponç, desejava identificar determinadas posturas para realizar uma obra de arte. Como propusemos para a compreensão de

\footnotetext{
261 TAPIÈS, Antoni. Op. cit., p. 220.

${ }^{262}$ V. Anexos.
} 
Joan Miró, aqui a pintura novamente seria um campo metafórico para pensar a poesia.

O primeiro a ser abordado é Tapiès. Ao não pensar a respeito dos limites do quadro, representaria o artista instintivo, menos intelectual; daí Cabral preferir mencionar "sua pintura" em lugar de "o pintor". Provavelmente levava em consideração telas como "El fuego encantado de Farefa" (1949) ${ }^{263}$, na qual triângulos e cilindros se acham dispersos em um vermelho intenso, para expressar uma "ordem instável", uma "iminência de catástrofe": "Sua pintura tira proveito, mais de uma vez, de um raro estremecimento que parecem provocar certos volumes muito próximos à moldura, certos pesos excessivamente poderosos que ele não se preocupou em neutralizar, buscando-Ihes a distância ideal da moldura que os teria estabilizado." O próprio Tapiès reconheceria que o amigo havia apontado "aspectos latentes que foram muito característicos" de sua obra posterior. ${ }^{264}$

Se o texto se detém no aspecto formal, o ideológico ficou reservado às conversas. Tapiès, em sua Memòria personal, especialmente na parte "Raízes catalãs. Psicanálise e marxismo", destacou o papel do amigo brasileiro na reflexão de uma arte comprometida ${ }^{265}$ : “(...) se fazia porta-voz daquela corrente mais inteligente que então começava a estar na moda entre alguns marxistas e que defendia uma arte de compromisso, à maneira de Brecht, entre o vanguardismo e o realismo socialista." No entanto, Tapiès questionou o ataque que Cabral dirigia à arte abstrata: “(..) também fazia sua uma posição que vinha dos que seguiam a 'linha' defendida pelos soviéticos: acrescentava que a pintura chamada abstrata que então era um dos movimentos da vanguarda artística - era inaceitável. E eu lhe perguntava: 'E se a forma de que dispõe um artista é abstrata? Então por acaso não está no mesmo caso de poder ter um compromisso?' Nestas questões percebi que já começava a haver imposições inexplicáveis em muita daquela gente que, por outro lado, como disse, não deixava de ser a representante do melhor ramo da estética que se queria marxista."266

Em 1950, Tapiés, juntamente com seu primo Cuixart, encontrou Cabral em Paris, que os acompanhou às livrarias especializadas do Partido Comunista Francês

\footnotetext{
${ }^{263} \mathrm{~V}$. Anexos, Imagens.

${ }^{264}$ TAPIĖS, Antoni. Op. cit, p. 238.

265 Tapiès também ofereceu um depoimento na seção "O amigo revisitado" dos Cadernos de Literatura Brasileira (Op. cit., p. 15-16).

${ }^{266}$ TAPIÈS, Antoni. Op. cit., p. 237.
} 
e os presenteou com livros. Entre as leituras, surgiam Marx e Engels, "textos de Plejanov sobre a arte e a vida social e outros autores mais panfletários, como Politzer, Kanapa, Lefèbvre..., todos publicados pelas Éditions Sociales”. ${ }^{267}$ Também abarcava os poetas comprometidos, como Neruda e Miguel Hernández. ${ }^{268}$ Com um verdadeiro sentido de formação, indicou-lhes aulas abertas da Universidade Operária fundada por George Politzer com professores como Roger Garaudy e Lefèvre. ${ }^{269} \mathrm{Em}$ carta a Brossa de 15 de dezembro desse ano, Tapiès comenta com entusiasmo tais revelações: "Ontem e hoje tive a alegria de poder abraçar Cabral, que esteve umas horas em Paris. Foi uma grande sorte vê-lo nestes momentos. Deu-me uma grande injeção de ânimo das suas e parece que graças a ele poderemos relacionar-se com pessoas interessantes. Presenteou-nos com uma pilha de livros e nos encarregou de que os façamos passar uma vez termos lido."270 Brossa recebeu outra carta em 8 de janeiro de 1951, desta vez de Cabral: "Gostei muito do espírito de Tàpies e Cuixart em Paris. Eles haviam já sentido o choque da decepção, no seu primero contacto com a arte formalista em seu próprio ninho. Eu, há tempos, havia previsto a coisa. E vê-la confirmada neles me alegrou."271

Toda essa carga de informação surtiu efeito na pintura de Tapiès, mas que não durou por muito tempo. Realizou obras com os sugestivos títulos Asia unida, Los hombres, Homenaje a Lorca, El trabajo nocturno, Homenaje a Miguel Hernández, Los oficios, Ellos acusan, considerando-as de "um período imaturo, de transição e com freqüência simplistas de conteúdo". ${ }^{272}$

Voltando ao texto de 1949, Cuixart comparece como o artista "mais intelectual". Sua liberdade em compor estaria justamente em fugir do limite da tela, para o qual coloca muita distância entre a moldura e a coisa pintada, reduzida a pequenos grupos dentro de uma superfície mais vasta: "Procura criar para as coisas que pinta um meio infinito, a fim de impedir que os olhos do espectador, ao contemplar a coisa pintada, tenham seu campo visual condicionado pela moldura. $O$ olho espectador, então, poderá se entregar ao ritmo interno da coisa pintada, que se encontra solta no espaço, a maneira de constelações." Explicação certeira para um

\footnotetext{
${ }^{267}$ Idem, ibidem, p. 274.

${ }^{268}$ Idem, ibidem, p. 281.

269 PAGĖS I SANTACANA, Mònica. Cuixart. Biografia inacabada. Barcelona: Parsifal Edicions, 2003, p. 106.

270 Idem, ibidem, p. 106-107.

${ }^{271}$ Arquivo Joan Brossa - Fundació Joan Brossa - Barcelona.

${ }^{272}$ TAPIĖS, Antoni. Op. cit., p. 281.
} 
quadro como "Compisició del cántir" [Composição do cântaro] (1949)273, em que pequenas e diáfanas figuras, distantes da moldura, "voam" em um vasto horizonte. Inclusive o cântaro do título não se encontra em lugar de destaque como em uma composição tradicional, devendo ser procurado pelo olho do espectador. Se o compararmos com a obra de Tapiès tomada aqui como exemplo, temos os dois primos pintores como exemplos contrários na percepção de Cabral: um "explosivo", aproveitando as sugestões do fogo do quadro, e o outro conscientemente "etéreo".

Por último, Ponç aparece como um tipo "intermediário", menos instintivo que Tapiès e menos intelectual que Cuixart, ou seja, possui os atributos dos dois, mas não como princípio de sua composição. Como grande traço diferencial, sua preocupação está mais na figura e menos na moldura da tela: "Ele não pinta sua liberdade: se serve dela como de algo que the permite entregar-se mais completamente ao sentido do objeto que pinta.(...) Quer se entregar à figura e por isso atribui menos importância à mecânica da tela." Ao não investir nem se afastar da moldura, procura preencher o espaço da superfície, e conseqüentemente, intensifica os sentidos de suas pertubadoras figuras: "Mas a uma liberdade maior de sintaxe tem que corrresponder, forçosamente, maior liberdade de metáfora. Em Ponç esta é bem visível na absoluta liberdade com que parece acometer o que mais mostra interessar-Ihe: a figura, livre de qualquer sistema interno conseqüente, de qualquer estilização." Talvez Cabral, nesse momento, quisesse se identificar com o tipo de artista representado por Ponç: se por um lado nunca foi um "instintivo", por outro, o "intelectual" começaria a pesar-Ihe. Por isso também investiria na "figura", compondo inclusive uma Paisagens com figuras, na qual cada uma - como nos quadros de Ponç - ramifica-se em várias metáforas.

Por outro lado, como fazia com os outros integrantes do Dau al Set, Cabral alertava Ponç de que deveria continuar pintando a seu modo, mas com alguma indicação social ou política, segundo lembrou Brossa: "Se eu te encarrego o retrato de um burguês, que farás: um burguês bajulador como em Duracamps ou um monstro? No início, as pessoas dirão que você está doente, mas é suficiente, para denunciar, que coloque no monstro um chapéu de copa; e, além disso, não será perigoso para a censura.",274

\footnotetext{
${ }^{273} \mathrm{~V}$. Anexos, Imagens.

274 PERMANYER, Lluís. Op. cit., p. 88. Também Cuixart evocou uma história parecida entre Ponç e Cabral: "(...) Joan Ponç, seguindo as diretrizes de Cabral, vai querer pintar um quadro onde aparecem guardas civis. Evidentemente, não tinha nada a ver com o seu mundo. Por isso, Cabral vai dizer-Ihe:
} 
A predileção pelas "figuras" de Ponç motivou Cabral, juntamente com Tormo, a editar em dezembro de 1949 um álbum com dez litografias dele ${ }^{275}$, realizadas entre novembro de 1948 a dezembro de 1949. Com esse trabalho, unindo edição e artes plásticas, Cabral encerrava sua frutífera convivência com as artes de Barcelona.

‘Has de seguir pintando monstruos, pero con tricornio..!” (PAGĖS I SANTACANA, Mònica. Op. cit., p. 81-82)

${ }^{275} \mathrm{~V}$. Anexos, Imagens. 


\section{CAPÍTULO 4: O museu espanhol de Murilo}

Entre os múltiplos interesses de Murilo Mendes, a pintura ocupava um dos lugares centrais. Não apenas escreveu poemas sobre artistas e telas, como também exerceu a crítica de arte, resultando nos livros póstumos $A$ invenção do finito e L'Occhio del poeta. ${ }^{276} \mathrm{O}$ contato direto com pintores no Brasil e na Europa intensificou a incorporação de um universo plástico a sua obra.

Já no início da década de 20 um pintor tornou-se uma referência fundamental para Murilo: Ismael Nery. Talvez o amigo tenha apresentado-lhe a arte moderna através de Picasso: "(...) Não posso precisar se nos primeiros anos de nossa convivência Ismael se referia aos pintores modernos, mas enclino-me pela negativa, embora poucos meses depois que o conhecia tenha ele me mostrado uma cabeça de homem pintada em azul, o que faria pressupor conhecimento de uma das primeiras fases de Picasso."277 Como dizia de si mesmo, não considerava Nery um "surrealista ortodoxo":

(...) apesar de todas as solicitações do surrealismo no sentido de se desarticular completamente o processo fundamental da pintura, Ismael Nery soube fazer uma síntese magnífica da modernidade com a arte clássica, revelando um perene cuidado na composição e na sobriedade das tintas, procurando, às vezes, soluções de arquitetura ou de escultura, outras vezes soluções mais violentas, arbitrárias, em que a imaginação excitada volta as costas a certos princípios construtivos elementares, mas sempre num espírito de lúcida pesquisa. ${ }^{278}$

A dialética entre "princípios construtivos" e "soluções mais violentas, arbitrárias" está na base de grande parte da poética de Murilo. Durante os anos 20 e 30, Nery trouxe-Ihe da Europa "abundante documentação" a respeito do surrealismo, principalmente Giorgio De Chirico ${ }^{279}$, "ídolo de sua mocidade”, e Max Ernst. ${ }^{280}$ As

\footnotetext{
${ }^{276}$ Publicados por Luciana Stegagno Picchio respectivamente em 1994 e 2001. Sobre $A$ invenção do finito, v. NEHRING, Marta Moraes. Murilo Mendes: crítico de arte. São Paulo: Nankin Editorial, 2002.

${ }^{277}$ Recordações de Ismael Nery. $2^{\mathrm{a}}$ ed. São Paulo: EDUSP; Editora Giordano, 1996, p. 100.

278 Idem, ibidem, p. 118.

279 Em exemplar com anotações para uma nova edição de Poemas (1930), datadas de 1960, Murilo deixou registrado que o poema "Mundo inimigo" fora "inspirado em quadros de G. de Chirico". (PCP, 1610)

280 "Giorgio De Chirico", Retratos-relâmpago - $2^{a}$ série (PCP, 1270-1271).
} 
técnicas de colagem e montagem de Ernst, por exemplo, fundamentaram o universo surrealista do poeta: "Confesso-Ihe o quanto Ihe devo, o coup de foudre que foi para o desenvolvimento da minha poesia a descoberta do seu prodigioso livro de fotomontagens La femme 100 têtes, só comparável, no plano literário, à de Les illuminations. De resto, creio que Max Ernst descende de Rimbaud, pela criação de uma atmosfera mágica, o confronto de elementos díspares, a violência do corte do poema ou do quadro, a paixão do enigma (aí foi ajudado pela obra do primeiro De Chirico)." (PCP, 1248)

Posteriormente, Murilo passou a se interessar por outros artistas, o que incentivou mudanças na poesia dele, a qual não apenas dialogava com o surrealismo ou o catolicismo, mas também se preocupava com a construção da forma na obra de arte. A propósito de uma exposição da portuguesa Maria Helena Vieira da Silva, exilada no Rio de Janeiro entre 1940 e $1947^{281}$, manifestou-se em texto publicado na Revista Acadêmica, em agosto de $1942 .^{282}$ Vinha das experiências de As metamorfoses, de 1938-1941, e Mundo enigma, de 1942, os quais incluem respectivamente os poemas "Maria Helena Vieira da Silva" e "Harpasofá (um quadro de Vieira da Silva)". Segundo Murilo, ela seria uma artista "eminentemente dialética", ao unir "tradição ao espírito de aventura e pesquisa". E valoriza principalmente o fazer artístico, dando um registro de quem seguiu de perto a pintora: "Em Maria Helena o exercício da construção plástica chega a assumir um caráter de ascese. Dia e noite sua lâmpada está acesa, e a infatigável operária move, move e move lápis e pincéis, sem que o mundo exterior a perturbe ou convença." Lança uma frase que resume a sua poética a partir de então: "Sua liberdade visionária é servida de uma técnica segura”. Considera Harpa-Sofá, escolhido como matéria de poema, uma obra-prima, "chegando a uma depuração, uma filtragem incomparáveis". "Depuração" e "filtragem” que também buscava em sua poesia.

Quando partiu à Europa em 1952, teve acesso a tudo aquilo que até então vira por fotos ou reproduções: "Além de inúmeras cidades de artes, museus, galerias antigas, modernas, igrejas, 'ateliers', etc., estabeleci contatos com personalidades

\footnotetext{
${ }^{281}$ Sobre as relações entre Murilo e Vieira da Silva consultar: MOURA, Murilo Marcondes. Op. cit., p. 136-138; PEREIRA, Maria Luiza Scher. Espaço e Memória II: Arquivos do exílio em Murilo Mendes e Vieira da Silva In Imaginação de uma biografia literária: os acervos de Murilo Mendes. Juiz de Fora: Editora da UFJF, 2004, p. 23-31.

${ }^{282}$ GUIMARÃES, Julio Castañón, org. Op. cit., p. 59.
} 
altamente interessantes." ${ }^{283}$ Entre vários artistas, destaca-se o pintor italiano Alberto Magnelli, que, assim como Miró em relação a Cabral, significou uma das vias privilegiadas para Murilo refletir sobre a sua obra. Em dezembro de 1955, quando iniciava Tempo espanhol, abordou o artista em texto para a revista paulistana Habitat. ${ }^{284}$ A possível conexão entre pintura e poesia ressalta em expressões como "textos plásticos" e "escritura de Magnelli", admitindo que o pintor "escreve o que pensa e quer escrever". Magnelli pertence à "linhagem de pintores rigorosos e severos", "grande exemplo de lucidez", à Miró. Entende a obra dele como uma "espécie de longa meditação, sempre desenvolvida e retomada, sobre a forma." Se por um lado a forma seduzia cada vez mais a Murilo, por outro, ela não implicava a abolição do conteúdo, a dimensão humana, confronto solucionado na obra de Magnelli: “(...) não se trata de encarar a forma e de dissecá-la cientificamente; não se trata de insistir nos valores geométricos do quadro, ou de separar forma e afetividade, linguagem interior e abstração; trata-se de re-criar e re-pensar continuamente $o$ estilo, de assegurar-Ihe o equilíbrio entre as duas tendências divergentes, a ordem e a aventura."

Ainda nesse texto, é expressiva a passagem em que comenta a chamada "fase das pedras" de Magnelli:

(...) Que segura intuição o guiou, ao escolher este material, o próprio signo da duração e da permanência! Onde a matéria surge mais forte, mais espiritual e mais imbricada na sua condição de símbolo, que na pedra?....

Eis que a solidão da forma é ultrapassada. Eis que a luz canta nas pedras e pelas pedras. Eis que as pedras não estão mais destacadas no espaço; elas o inauguram, elas próprias o constróem.

Em consonância com Cabral, para quem a pedra tornou-se um signo decisivo, Murilo serviu-se dela para revelar a diversidade de sua obra. Benedito Nunes observa que nos anos 40 a "pedra aparece como elemento produtor de metamorfoses. 'Sou aquela nuvem andante,/ O pássaro e a estátua de pedra.' ('O Emigrante', As metamorfoses, Livro Primeiro). - "A grande dignidade das pedras/

\footnotetext{
${ }^{283}$ FONSECA, Edson Nery da, org. Op. cit., p. 26-27.

284 "Magnelli" (GUIMARÃES, Julio Castañon, org. Op. cit., p. 67-72). V. RODRIGUES, Marisa Timponi P., org. Magnelli; mostra do acervo do Centro de Estudos Murilo Mendes. Juiz de Fora: CEMM/UFJF, 1998 e NEHRING, Maria Moraes. O amigo Magnelli. Op. cit. p. 103-140
} 
Exclui arco de triunfo". ('Estudo no. 3', idem)"285. Avançando para o mundo da história e das cidades, em Contemplação de Ouro Preto, a antiga Vila Rica recebe o epíteto "Dama de pedra". ${ }^{286}$ Sua correlata européia, a também montanhosa Toledo, decifra a Espanha: "Toquei em Toledo a linguagem espanhola,/ A pedra, sua força concentrada." (PCP, 590).

E a Espanha contribuiu muito para conformar o cenário plástico e poético de Murilo. As considerações que emitiu sobre o pintor inglês Hayman Chaffey poderiam referir-se a ele mesmo: "A propósito: Chaffey foi à Espanha fazer provisão de luz. $O$ espaço. A luz. A cor ali sempre presente. $\mathrm{Na}$ atmosfera espanhola encontrou sua pátria espiritual e explodiu." ${ }^{287}$ Espaço e cor que avultam nos poemas de Tempo espanhol, coletânea que também expõe seu museu, com os mais importantes pintores da história da arte espanhola. No texto "A lata de lixo", de Poliedro (1972), comenta de forma irônica as escolhas de seu canôn pictórico:

Eu me chamo, e todos os outros me chamam, Murilo. Dum ponto de vista puramente eufônico e visual preferiria chamar-me por exemplo Goya, Velázquez ou Zurbarán.

Malandro e hipócrita sou! Bem vejo que não se trata de um ponto de vista puramente eufônico e visual, trata-se de atenção à hierarquia dos valores: mesmo contrariando Ortega y Gasset, mesmo reconhecendo o interesse dum certo lado da obra de Murilo, o lado mais realista, não o situo no plano dos outros três pintores. (PCP, 1008)

De todos os modos, nenhum dos dois pintores da chamada escola sevilhana, Francisco de Zurbarán (1598-1664), e o xará Bartolomé Esteban Murillo (1617-1682) figuram em Tempo espanhol. Os poemas acerca dos pintores, como os dos escritores, vinculam-se também à biblioteca do poeta, que guarda várias monografias e catálogos de pintores e períodos artísticos, fartamente anotados. Os poemas e as anotações englobam duas formas de reflexão, a da Espanha e a da própria poesia.

Seguiremos, neste capítulo, a disposição cronológica de Tempo espanhol: a arte românica da Catalunha, El Greco, Velázquez, Goya e três artistas do século XX,

\footnotetext{
${ }^{285}$ NUNES, Benedito. Op. cit., p. 37.

${ }^{286}$ Verso 242 de "Romance de Ouro Preto" (PCP, 479).
} 
Picasso, Juan Gris e Miró. Para completar o quadro, comentaremos o pequeno texto que Murilo dedicou à artista hispano-brasileira Isabel Pons, em $A$ invenção do finito.

\section{A pintura antiga da Catalunha}

Murilo datou do primeiro ano de sua viagem à Europa a grande revelação que constituiu a visita ao Museu de Arte Antiga da Catalunha:

Barcelona é rica em coleções de arte. O Museu de Arte Antiga da Catalunha reúne na colina de Montjuich um conjunto excepcional de afrescos, painéis, esculturas em madeira, elementos arquitetônicos, todos de estilo românico, além de quadros e outras peças de épocas posteriores. A parte românica é considerável e creio que sem igual em toda a Europa. Vide mormente as salas № 1 a 13, com afrescos provenientes de Pedret, Esterri d'Eneu, La Seo d'Urgel, o formidável Pantocrator do mestre de San Clemente de Taüll: foram trasladados de igrejas e capelas medievais dos Pirineus (de há muito tempo sem culto) por meio duma técnica especial. A pintura antiga catalã é altíssima, ao nível de criação estética que nos deu os "primitivos" flamengos e italianos. Meu primeiro encontro com essa pintura, no longíquo ano de 1952, causou-me um choque de que não regressei até hoje..$^{288}$

$\mathrm{Na}$ biblioteca do poeta, a fascinação pela arte românica mostra-se na presença do sexto volume, Pintura e imagenería románicos, da monumental Ars Hispaniae. Historia Universal del Arte Hispánico. ${ }^{289} \mathrm{O}$ livro Les maitres de la peinture espagnole: El Greco-Velázquez, de Eugène Dabit ${ }^{290}$, apesar de trazer na folha de rosto a anotação "M. M. 1940", provavelmente foi lido ou relido depois de 1952, pois, diante de duas considerações da introdução, Murilo escreveu à margem "e os primitivos catalães?...": a de que a obra de dois homens, El Greco e Velázquez, é essencial à pintura espanhola, e a de que não se encontra na Espanha o equivalente aos primitivos italianos.

\footnotetext{
${ }^{287}$ A invenção do finito (PCP, 1305).

${ }^{288}$ Espaço espanhol (PCP, 1168).

${ }^{289}$ COOK, Walter William Spencer e RICART, José Gudiol. Madri: Ed. Plus-Ultra, 1950.

$2904^{\mathrm{a}}$ ed. Paris: Gallimard, 1937.
} 
Em Tempo espanhol, nada menos que três poemas consecutivos foram dedicados à arte românica: "Aos pintores antigos da Catalunha", "A Virgem de Covet" e "As carpideiras". Para os dois últimos, incluiu indicações museológicas para situar o leitor, respectivamente, "Imagem do século XIII, vinda da Igreja de Covet. Museu de Arte Antiga, Barcelona" e "Pinturas do sepulcro de Don Sancho Saiz Carrillo. 1300. Museu de Arte Antiga, Barcelona".

"Aos pintores antigos da Catalunha" vem logo em seguida de "Aos poetas antigos espanhóis", as faces literária e pictórica da Espanha medieval. Sintetiza em verso as principais impressões da arte românica:

\author{
Fundais o horizonte plástico da Espanha. \\ Fundais a proporção na majestade, \\ A matéria da vida não transposta, \\ Antes exposta com lucidez didática \\ E medida exata da caligrafia. \\ Sabeis irradiar as cores, \\ Criais largos panejamentos. \\ Enganais a pespectiva. \\ Comprimis a perspectiva. \\ Rigor de arte e de vida. \\ Fixais o alto objeto do plástico, \\ Tradição do primeiro sol futuro \\ Que irrompe vertical do Apocalipse: \\ Vive no espaço \\ O Cristo com sua descendência.
}

Nos afrescos românicos, medida da Catalunha,

O símbolo em valor concreto já se muda. (PCP, 580)

A religião visualizada em cores e formas vigorosas, "lucidez didática", impressionou Murilo. O divino poderia ser transmitido com "exatidão" e "rigor", o símbolo transformado em "valor concreto". Para esse poema, seguramente tomou como referência "o formidável Pantocrator do mestre de San Clemente de Taüll". ${ }^{291}$ Pantocrátor designa a imagem de Cristo mais conhecida em que aparece representado frontalmente, bendiz com a mão direita e segura o livro com a esquerda. Retirado da igreja de Sant Climent de Taüll para compor o âmbito V do

${ }^{291}$ V. Anexos, Imagens. 
Museu Nacional de Arte da Catalunha, é uma das obras mais representativas da arte românica. Termos do poema remetem-nos a essa pintura mural: o Cristo é uma figura em "majestade"; sua túnica branca e cinza e manto azul revelam "panejamentos", dobras e ondulações, oferecendo a ilusão de movimento. Letras e palavras colaboram na lição divina: nos dois lados do Cristo, as letras alfa e ômega, primeira e última do alfabeto grego, indicam que ele é o princípio e o fim de todas as coisas (Apocalipse 1, 8; 21, 6; 22, 13); no livro aberto em sua mão esquerda lemos a inscrição "Ego sum lux mundi" ("Eu sou a luz do mundo", João 8, 12). Abaixo de Cristo, sua "descendência" em semi-círculo, diversos santos e apóstolos marcados por arcos e colunas. ${ }^{292}$

No entanto, Murilo não se deteve apenas "no alto objeto da plástica", do Cristo Todo Poderoso, tendo se aproximado das manifestações mais populares do culto religioso, como a Virgem de Covet:

\author{
Nessa talha policroma \\ Resumo o estilo severo \\ Dos primeiros catalães, \\ Mestres da força, escultores: \\ Construíram sua fantasia \\ Com materiais reduzidos. \\ Ordenaram a solidez \\ Anulando as formas frouxas. \\ Substituíram à dureza \\ Da imagem sacra distante, \\ A proximidade do humano: \\ Elementos que ajustados \\ Pela ternura concisa \\ E a carga da ldade Média \\ Criaram a Virgem de Covet. (PCP, 580-581)
}

A Virgem de Covet encontra-se no âmbito VIII do Museu Nacional de Arte da Catalunha ${ }^{293}$, ao lado de outras imagens talhadas em madeira. De aspecto rústico, os traços faciais são mais familiares, com um leve sorriso ${ }^{294}$, reconhecidos pelo poeta: "Substituíram à dureza/ $\mathrm{Da}$ imagem sacra distante,/ $\mathrm{A}$ proximidade do humano:". Porém, o que fora aplicado à escultura valia também para seu verso:

\footnotetext{
${ }^{292}$ CARBONELL I ESTELLER, Eduard et alli. Guía arte románico. Barcelona: Museu Nacional d’Art de Catalunya, 1998, p. 70-75.

${ }^{293} \mathrm{~V}$. Anexos, Imagens.

${ }^{294}$ Idem, ibidem, p. 111.
} 
"Construíram sua fantasia/ Com materiais reduzidos./ Ordenaram a solidez/ Anulando as formas frouxas". Com pouco e eliminando o excesso, promoveu um novo direcionamento para sua poesia. Por isso, levantamos a hipótese de que o "choque" causado pela arte românica, em 1952, pode ter sido um dos estímulos decisivos para o conduzir à poesia de Siciliana, de 1954-1955, e Tempo espanhol, de 1955-1958.

\section{El Greco, o pintor de Toledo}

O interesse de Murilo por El Greco (1541-1614) viria de muito cedo, de uma leitura do livro de Maurice Barrès, Greco ou Le secret de Toled, aos 17 anos. ${ }^{295}$ Por sinal, esse título conserva-se em edição de 1951 nas estantes do poeta, acompanhado por outros seis exemplares anotados a respeito do pintor.

Nos primeiros anos de Europa, além da arte românica, a cidade de Toledo revelou-se uma grande surpresa para Murilo, abrindo-Ihe o panorama da História. Em exemplar de El Greco de Manuel de Cossío, cuja folha de rosto registra um possível instante de leitura - "M. M. Madrid, 1952" -, recebeu destaque a descrição da singular cidade, de "excepcional situação topográfica, áspera e elevada rocha de granito, apertadamente circunscrita". ${ }^{296}$ Como no título da monografia de Barrès, Toledo está intimamente associada a El Greco. Nascido em Creta, Domenikos Theotokopoulos fixou residência em Toledo por volta de 1577. Confirmando sua identificação com a nova pátria, dedicou duas telas à cidade - Vista de Toledo (1597-1599) e Vista y plano de Toledo (1610-1614) -, como também às vezes incorporou motivos urbanos em seus quadros. Vista de Toledo, que integra o acervo do Museu Metropolitano de Arte de Nova lorque, com seus vários planos e nebuloso céu ao fundo, suscitou em Murilo a arte moderna: "espantosa, pré-moderna vista de Toledo"297, precursora da liberdade estética do século XX, prodígio de gênio da invenção e da metamorfose. ${ }^{298}$ Desde o poema "Uma nuvem", de As metamorfoses, visita-se o dramatismo da esfera celeste de EI Greco:

\footnotetext{
${ }^{295}$ ARAÚJO, Laís Correa de. Op. cit., p. 356.

${ }^{296}$ COSSIO, Manuel B. El Greco. $2^{\mathrm{a}}$ ed. Madri: Espasa-Calpe, 1948, p. 73-74.

${ }^{297}$ Carta geográfica (PCP, 1117).

${ }^{298}$ Espaço espanhol (PCP, 1135-1136).
} 
Quem poderia pintar esta nuvem?

Só mesmo Domenico Teotocopuli

Mergulhando seu pincel no caos,

Ao sopro da sua estranha lucidez. (PCP, 367)

Em Tempo espanhol, o poema "Toledo", o mais longo da coletânea, explicita a relação entre pintor e cidade: "Os objetos de tocaia,/ O céu se abrindo em crateras/ Como nos quadros de El Greco. (...) Eis Toledo como El Greco a tocou e pintou:/ O máximo de intensidade no mínimo de espaço." (PCP, 591). Insiste mais uma vez, no poema seguinte, "El Greco": "Em Toledo sua matéria e forma própria." (PCP, 592). E como não poderia deixar de ser, em Espaço espanhol, a parada em Toledo obriga a referência a El Greco, irmanados não só pelo gênero paisagístico, mas também pelo Retrato del Cardenal Tavera (1608-1614), o qual "poderia significar o estema da cidade: severa, apostando com a morte, autovisionária, recriada por um pintor do absoluto que, nascido longe, soube incorporá-la até o osso; provavelmente sua psique foi alterada pela planta irregular de Toledo." (PCP, 1137).

Outros quadros mereceram a atenção de Murilo. Em Tempo espanhol, o poema "O sol de llhescas" "prepara a El Greco", a partir do quadro San Ildefonso (1603-1605), que está no Hospital de Caridad de Illescas:

Quem dá de comer e beber a llhescas

Com sua linguagem seca de tijolo

E homens secos?

Ilhescas prepara a Toledo.

Quem dá de comer e beber a Santo lldefonso

Que, suspenso à parede por El Greco,

Escreve inspirado pela Virgem?

Não vereis uma outra tela tão castiça:

Extraída à substância mineral da Espanha. (PCP, 589)

No sexto segmento do poema seguinte, "Toledo", realiza uma verdadeira análise da tela El entierro del Conde de Orgaz (1586-1588) $)^{299 .}$

${ }^{299}$ V. Anexos, llustrações. 
Sobe para o céu o cavaleiro de Orgaz

Que inserido em dois planos

Ainda se comunica à terra

Pelo fogo comprimido de Toledo.

Cada figura toledana que o cerca

Participa da sua morte:

De ferro, surda.

O silêncio explode no quadro,

Na composição cerrada do primeiro plano:

Silêncio e secura de Espanha

Onde a morte, elemento ainda de vida,

Marca a ressurreição do homem nu

Que o segundo plano indica. (PCP, 591)

Nas suas leituras, além do livro de Manuel Gómez-Moreno inteiramente dedicado a esse quadro ${ }^{300}$, Murilo valeu-se da observação de Juan Cassou, marcada com dois traços, sobre uma dualidade, tão ao gosto do poeta, baseada na dupla formação do pintor: "(...) violenta antinomia, antinomia que constituye toda la riqueza del genio del Greco, esta oposición perpetua entre su pasado oriental; es decir, litúrgico, alusivo y riguroso, y la lección del Occidente histórico que aspira incansablemente a aprisionar la realidad que huye. ${ }^{\text {"301 }}$ Nesse sentido, sublinhou na obra citada de Eugène Dabit as duas diferentes visões sobre El Greco - "(...) un croyant et visionnaire, et les autres un peintre, un homme" - para anotar em francês: "il est tout ça."302

Não apenas os homens "secos", "descarnados", retratados por El Greco aludem a uma Castilha, a uma Espanha almejadas pela poética de Murilo, como também a "espessura concreta" de Toledo tem seus correlatos na pintura e na poesia. Murilo destacou, na monografia de Juan Cassou, uma afirmação que aproxima El Greco a Góngora: “(...) Todo en el Greco, como en Góngora, es apretado e inseparable, lívido y ceniciento, todo es duro"303. Talvez El Greco tenha conhecido Góngora por intermédio de Fray Hortensio Paravicino, de quem deixou um retrato. Góngora, por sua vez, escreveu um poema, "Inscripción para el sepulcro de Domínico Greco", por ocasião da morte do pintor em 1614. Assinalado por Murilo em sua edição de Poemas y sonetos, significativamente, no soneto, o sepulcro é "dura llave":

\footnotetext{
${ }^{300}$ GÓMEZ-MORENO, Manuel. El entierro del conde de Orgaz. Barcelona: Editorial Juventud, 1951. 301 CASSOU, Juan. El Greco. Trad. José López y López. Barcelona: Ediciones Hymsa, 1934, p. 9596.

${ }^{302}$ DABIT, Eugène. Op. cit., p. 85.
} 

Esta en forma elegante, oh peregrino, de pórfido luciente dura llave el pincel niega al mundo más süave, que dio espíritu a leño, vida a lino.

Su nombre, aun de mayor aliento digno que en los clarines de la Fama cabe, el campo ilustra de ese mármol grave. Venérale, y prosigue tu camino.

Yace el Griego. Heredó Naturaleza arte, y el Arte, estudio; Iris, colores; Febo, luces - si no sombras, Morfeo. -

Tanta urna, a pesar de su dureza, Lágrimas beba y cuantos suda olores corteza funeral de árbol sabeo. ${ }^{304}$

Ao lado do estilo, a temática religiosa, como na arte românica, tornou-se um meio privilegiado da identificação de Murilo com a pintura de El Greco. Por exemplo, o dramatismo de seus santos arrependidos, interlocutores emocionais dos crentes, que se assemelham a eles. Repetia-se assim o efeito causado pela Virgem de Covet, "Da imagem sacra distante, a proximidade do humano":

\author{
Desde então ajusta ao homem \\ Seus anjos e seus santos. \\ O santo participa de nós todos, \\ Comunga nossa matéria mineral, \\ Comunga nossa aridez e nossa lida. \\ Por isso El Greco trata-o como homem \\ Antes de o transladarem aos altares: \\ Homem castelhano vertical, \\ Submisso à lei interior que o alimenta e consome. \\ Quanto ao anjo: sem a ótica do homem, \\ Quem o situaria? (PCP, 592-593)
}

\title{
3. Velázquez, "eis a pintura"
}

Último poema da série dedicada ao Siglo de Oro em Tempo espanhol, "Velázquez" pode ser considerado o centro nevrálgico da história da pintura espanhola proposta por Murilo. A arte românica e El Greco fundam o "horizonte", o

${ }^{303}$ CASSOU, Jean. Op. cit., p. 78. 
"estilo" pictórico de Espanha, de Castela, enquanto Goya e os artistas do século XX avançam na modernidade. Para Murilo, Diego Velázquez (1599-1660) levaria ao máximo algumas caracterísicas comuns a esse acervo, disseminadas ao longo do poema:

Andaluz e castelhano,

Resume a tensão espanhola.

Entre precisão e força

Ordena sua paleta.

Eis a pintura.

Eis a matéria do homem a duas dimensões.

Pintando, Velázquez orienta

A rígida consciência de Espanha:

Orgullo castelhano de estrutura,

Ligado à língua e ao solo.

Velázquez sabe: pintar é elucidar o espaço

Aberto ou restrito

Pela marcha do pincel consciente

Velázquez sabe: a cor delimita a forma.

Situando a cor, seu pincel a define:

Suprime a fluidez, a suavidade,

Qualquer elemento opaco ou impreciso.

Suporte da verdade plástica

É o próprio grupo dos nobres:

Entre o rei e o niño de Vallecas

A continuidade da matéria enxuta.

A marcha do pincel voluntário

Constrói o homem na grandeza circunscrita:

Sua dimensão é a cor, a forma definida.

Eis o que o distingue dos outros:

Seu DUENDE não é visível

Como o de Goya, de El Greco.

Entre o minucioso "fantástico" de Flandres

E o gosto superlativo italiano

A linha castigada e enxuta de Velázquez

Demarca os precisos limites

Onde Espanha se reconhece autônoma. (PCP, 599-600)

${ }^{304}$ Op. cit., p. 59. 
Ao contrário de El Greco, por exemplo, a arte sacra não ocupou o centro da obra de Velázquez, consagrando-se como retratista da corte de Felipe IV (16211665). Pintou do rei aos anões, como Francisco Lezcano, el Niño de Vallecas (1643$1645)^{305}$, com a mesma "matéria enxuta". Se El Greco é visionário e pintor ao mesmo tempo, Velázquez é antes de tudo um pintor. Por isso, além dos importantes ensaios de José Ortega y Gasset ${ }^{306}$, Murilo destacou uma consideração da mencionada obra de Eugène Dabit: “(...) ele sabe compor com abastança, mas jamais cai no decorativo como os Italianos. Mal ele procura exprimir os sentimentos, ainda menos as idéias. Ele pinta, ele se exprime em pintura., ${ }^{307}$ Dessa maneira, concentrou-se no pintor, no seu modo de pintar, chegando a ser a própria explicação de uma arte: "Eis a pintura". Para tanto, freqüentam o poema o verbo pintar e as metonímias paleta e pincel.

Velázquez representa o artista consciente, seguro de seu ofício; os verbos acionados por Murilo indicam essa postura: "ordena", "orienta" e "sabe" (2 vezes). 0 pincel não se deixa levar, marcha "consciente", "voluntário". O material de trabalho, a cor, é a sua "dimensão", delimitando e definindo a forma, assim como, nesse momento, a palavra para Murilo. Mais uma vez, a pintura oferece lições para uma poética: "Suprime a fluidez, a suavidade,/ Qualquer elemento opaco ou impreciso." A subtração, que na Virgem de Covet vem "anulando as formas frouxas" e em El Greco aparece em suas figuras "secas", resulta em Velázquez no "enxuto". Portanto, não é de estranhar que ele, no "Murilograma a João Cabral de Melo Neto", esteja entre as preferências dos dois poetas, além de outro pintor em que o fazer se impõe, Joan Miró.

No segmento final do poema, coloca-se Velázquez no contexto da pintura espanhola e internacional. Para diferenciá-lo de El Greco e Goya, recorre-se ao Duende, o encanto misterioso e inefável do cante flamenco, reminiscência da Sevilha natal do pintor. Seu Duende não é explícito como o dramatismo que muitas vezes habita as telas dos outros dois, ocultando-se em sua técnica. Por outro lado, não vai aos extremos do "minucioso" 'fantástico' de Flandres" e o "gosto superlativo italiano", este mencionado no trecho de Dabit, criando uma Espanha "autônoma", única, que paira sobre os modelos estrangeiros. Apesar do apreço que nutria pela

\footnotetext{
${ }^{305}$ V. Anexos, llustrações.

${ }^{306}$ Papeles sobre Velázquez y Goya (Madri: Revista de Occidente, 1950) e Velázquez (Madri: Espasa Calpe, 1963).

${ }^{307}$ DABIT, Eugène. Op. cit., p. 97.
} 
Itália e pela Holanda, a Espanha sobressai para Murilo. Se, em relação à Itália, disse a Cabral que era um país traduzido e, a Espanha, um país por traduzir, ao abordar a Holanda em Carta geográfica necessitou de seu antípoda, a Espanha:

Esta Holanda de planícies, moinhos, canais, luz difusa, museus exemplares, prodígio de construção da inteligência e da técnica opondo-se ao despotismo das águas, exerceu sobre mim desde o primeiro momento uma fascinação que pareceria singular num homem habitado, como eu, pela figura da Espanha. Certamente a Holanda e a Espanha são antípodas; por isso mesmo no meu espírito não existe conflito entre as duas potências, embora a Espanha me apareça mais prestigiosa. (PCP, 1081)

\section{O touro e toureiro Goya}

Entre "Velázquez" e "Goya", apenas o poema "Chuva em Castela" a separar quase um século. $O$ poeta recolhe-se à meseta castelhana diante da decadência espanhola e da esterilidade artística: "A história circula insatisfeita/ ao largo da planície autárquica." (PCP, 600). Entre as cores dos dois pintores, a chuva torrencial "sacando o preto do branco".

Francisco de Goya y Lucientes (1746-1828), ao lado de El Greco, cedo despertou a admiração de Murilo para a pintura espanhola, de acordo com indicações de duas obras de sua biblioteca: na folha de rosto da monografia de Pierre Fréberix ${ }^{308}$, está anotado "M.M 1928", e na de Juan de la Encina ${ }^{309}$, a dedicatória, "Ao Murilo com um grande abraço Athos - 1943".

No poema de Tempo espanhol, Goya é visto sob a ótica da tauromaquia, sobre a qual, logo adiante, aparecem na coletânea "O rito cruento" e "Na corrida":

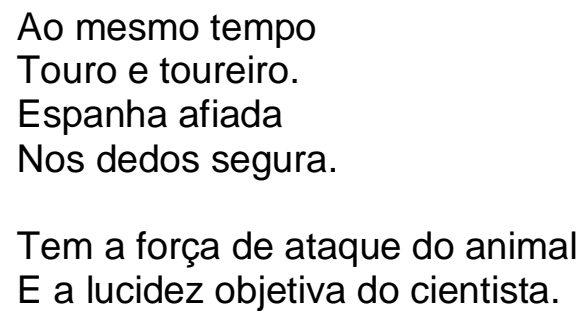

${ }^{308}$ Goya. Paris: L'artisan du livre, 1928.

${ }^{309}$ Goya: su mundo histórico y poético. México: La Casa de España en México, 1939. 
O gosto bem espanhol

De passar a vida ao fio da espada. (PCP, 600)

Entusiasta da tourada, Goya transformou-a em motivo pictórico ao longo de sua obra. Entre 1815-1816, revelando um grande conhecimento da matéria, realizou uma série de gravuras intituladas La tauromaquia, que se encontra em edição de 1950 nas estantes de Murilo. ${ }^{310}$ A gravura de número 20 - Ligeireza e Atrevimento de Juanito Apiñani $i^{311}$ - pode ter sido uma grande sugestão para o início do poema: com a ajuda de um bastão, o toureiro sobrevoa o touro que investe, "força" e "lucidez" simultâneas.

Apesar de ter sido pintor da nobreza, Goya não deixou de criticar a sociedade e os acontecimentos de sua época, principalmente nas séries de gravuras que deixou, os Caprichos e Desastres de la guerra. A respeito delas, assim se manifestou Murilo, valorizando a postura "comprometida" do pintor espanhol:

(...) constituem um dos mais fortes libelos jamais levantados pela razão humana contra os poderes do mal e da destruição, contra qualquer espécie de guerra, de tortura e de intolerância. Protesto não só contra a "guerra grande", mas contra as pequenas guerras cotidianas da vida individual, da vida social e política; contra essas fragmentações da guerra que, somadas, constituem a guerra total. Assim Goya, por meio do seu enorme poder plástico de captação das forças do mal apresenta a luta interminável de libertação do homem de seus institintos primitivos, criando uma obra que é, na sua essência, a de um civilizador. ${ }^{312}$

Essa coragem, que parte da imagem da tourada, segue na $3^{\mathrm{a}}$ estrofe do poema intensificada pelo adjetivo cruel - repetido 3 vezes - e pelo verbo investir:
Cruel para conhecer,
Cruel para delimitar
O território castigado,
Investindo alternadamente
O corpo da Espanha adversa,
$O$ rosto bifronte da Igreja.

\footnotetext{
${ }^{310}$ GOYA, Francisco de. La tauromaquia. Introdução e notas de Mariano Sanchez de Palacios. Madri: Aguado, 1950.

${ }^{311} \mathrm{~V}$. Anexos, Imagens.

312 "O homem Vedova" In A invenção do finito (PCP, 1355-1356).
} 
Cruel mesmo quando trata

Com aparente carinho

O rosa, o prateado e o cinza. (PCP, 600-601)

A outra face da Igreja foi denunciada por Goya nas obras em que expressa a irracionalidade da Inquisição e o fanatismo religioso. Também Murilo, nos poemas finais de Tempo espanhol - "O padre cego" e "O Cristo subterrâneo"313 - voltou-se contra a Igreja irmanada com a didatura e os poderosos. Por outro lado, Goya, como Velázquez, pouco praticou a tradicional pintura de tema religioso. Nesse terreno, ao mesmo tempo que atacava a Igreja nos Caprichos, encarregou-se em 1798 do afresco para a cúpula e abóbada da igreja de San Antonio de la Florida. Em lugar do modelo da cúpula como uma esfera do divino, Goya representou Santo Antonio na paisagem rochosa da Espanha, aparecendo diante de uma multidão apinhada atrás de um parapeito, como se tratasse de um fato da vida pública. ${ }^{314} \mathrm{O}$ encanto de Murilo por tal obra fez registrá-lo em Espaço espanhol:

Sempre que visito Madrid volto a San Antonio de la Florida, onde (menos o crânio) sepultaram Goya, sob uma de suas obras maiores, os afrescos que ajudaram o advento da modernidade; podemos observá-los melhor com a ajuda dum espelho adrede. Faltando a Goya o timbre religioso, os afrescos resultam numa transposição da vida madrilena muito mais que da de Santo Antônio. Obra profana, enigmática, tocada de sensualidade, culmina numa invenção de cor e desenho, planificando 0 arbitrário. Anuncia não só Manet e Degas, mas também o "pintor" Baudelaire, que de resto no seu poema À une Madame pressentiu o charme trágico da Espanha. (PCP, 1133)

Nesse caso, ao aproximar o divino do humano, Goya pertenceria à linhagem do artista anônimo da Virgem de Covet e de El Greco.

Significativo que Murilo não tenha feito nenhuma alusão no poema de Tempo espanhol às criações fantásticas e pertubadoras dos Caprichos, e sobretudo à fase final do pintor, as chamadas "pinturas negras" e as gravuras dos Disparates, mais sugestivas para alguém que freqüentou o surrealismo. Nesse momento de sua poesia, preferiu fixar-se em um Goya mais incisivo, mais concreto, para utilizar o

\footnotetext{
${ }^{313}$ V. Capítulo 2.

${ }^{314}$ V. Anexos, llustrações.
} 
termo chave da coletânea de 1959, que inclusive "inaugura o povo espanhol" (4 ${ }^{\mathrm{a}}$ estrofe). Por isso, a afirmação atribuída a Goya no livro de Pierre Frébérix, assinalada por Murilo talvez por volta de 1928, pode ser mais apropriada para 0 autor de Poemas de 1930 do que o de Tempo espanhol: "A pintura, ele declara, igual que a poesia, escolhe no universo o que ela encontra de mais apropriado a seus fins; ela reúne em um só personagem fantástico as circunstâncias que a natureza apresenta esparsas entre diversos indivíduos, e é apenas graças a esta combinação sábia e engenhosa que o artista pode aspirar ao título de inventor e deixar de ser um copista servil." ${ }^{315}$

\section{A desordem e a ordem do século XX: Picasso, Gris e Miró}

Depois de Goya, sucedem-se alguns poemas até atingirmos o cerne da arte moderna na Espanha, profundamente vinculada à Paris das vanguardas: Picasso, Juan Gris e Joan Miró.

Como vimos, Murilo, no começo da década de 20, talvez já conhecesse a "fase azul" de Pablo Ruiz Picasso (1881-1973). De todos os modos, a partir do contato com a Europa e a Espanha, o pintor passou a ocupar lugar de relevo em seu museu em forma de palavra. No poema de Tempo espanhol, valoriza-lhe "o estilo de contrastes", aliás também cultivado pelo poeta em grande parte de sua obra: "Construindo e destruindo ao mesmo tempo" e fundindo "a força e a contenção". Também as "metamorfoses" de técnicas e estilos enfrentados pelo pintor seduziram o múltiplo Murilo. Mais adiante, no segundo segmento de "Guernica", focalizou um setor da vasta e impactante tela de 1937:

Sem a beleza do rito castigado,

Aumentando a comarca da fome,

O touro de armas blindadas

Investiu contra a razão:

Eis que já Picasso o fixou,

Destruindo a desordem bárbara,

Com duro rigor espanhol,

$\mathrm{Na}$ arquitetura do quadro. (PCP, 618)

${ }^{315}$ Op. cit., p. 70. 
No retrato-relâmpago dedicado a Picasso, retomou o quadro: "O enigma da tauromaquia, transposto em chave plástico-política de exegese da guerra civil, explodirá numa dimensão cósmica em 'Guernica'” (PCP, 1247). Justamente nesse texto, aproveitou como metáfora crítica a predileção do pintor pela tauromaquia, explorada ao longo de sua trajetória, assim como fizera com Goya: "Permanecerá toureiro durante a vida inteira; avesso ao bizanistismo das teorias, polêmico e ambíguo, toureará os monstros Velázquez, Goya, Delacroix; toureará a pintura européia do século XX, fechando o ciclo histórico iniciado com a Renascença." (PCP, 1246). Ainda segundo Murilo, exacerba "as forças passionais do próprio instinto", resultando em um "romântico" Picasso, artista de "gênio", freada apenas durante a militância cubista: "O tempo de hoje, tempo coletivo, continua a ser o tempo particular do superindividualista Pablo Picasso, provocador da própria apoteose, distante quase sempre, salvo no período cubista, da rigidez estrutural; fértil em improvisações e scherzi, infatigável operador do figurativismo, mormente através dos esquemas da 'deformação'; de Picasso, mestre de metamorfoses, que se dá romanticamente em espetáculo, (...)" (PCP, 1247).

Assim, o contraste com o poema seguinte de Tempo espanhol, "Juan Gris", torna-se mais evidente, pois se detém em um dos maiores representantes do cubismo. Da multiplicidade de Picasso passamos à concisão de Gris. Vizinho de estudio de Picasso em Paris, José Victoriano González (1887-1927), nome verdadeiro do pintor, impulsionou a passagem do chamado "cubismo analítico" para o "cubismo sintético". No "cubismo analítico", fracionava-se a figura em formas essenciais, decompondo geometricamente os planos para destruir o seu aspecto aparente, exterior. Já o "cubismo sintético" procurou o equilíbrio entre a geometria e o mundo da experiência, ao trazer para a obra objetos da vida cotidiana, a exemplo das recorrentes garrafas, vasos, xícaras e guitarras. Empregou-se, então, a técnica do papier collé, que consistia em colar no quadro materiais diversos como recorte de jornal, de papel de parede ou cartões. Entre 1912 e 1914, Gris levou ao máximo essa tendência, com rigor de formas e cores.

Embora tenha acompanhado os quadros cubistas de Ismael Nery, entre 1922 e 1927, Murilo elegeu como pintores preferidos os relacionados ao surrealismo, De Chirico e Ernst. Contudo, data pelo menos de sua primeira temporada na Europa uma retomada do cubismo, como verificamos na anotação na folha de rosto da segunda edição de 1946 da obra de Daniel-Henry Kahnweiller, Juan Gris sa vie, son 
oeuvre, ses ecrits: "Murilo Mendes. París 1955", ano do início da composição de Tempo espanhol, que reserva um poema ao pintor:

\author{
Espanha, mestra do espaço, \\ Deu a pureza, medida \\ $\mathrm{Na}$ área total da pintura \\ Com o gênio da concisão, \\ Pelo pincel de Juan Gris. \\ Nessa pintura pensada \\ Com clareza dialética, \\ Espanha, dita "irracional", \\ Pelos planos de Juan Gris \\ Mostra o acordo e a simetria. (PCP, 617)
}

No museu que percorremos, trata-se do poema mais conciso e medido, com duas estrofes de cinco versos heptassílabos. Cada estrofe contém um período: na primeira, a ordem sintática é direta, com sujeito, predicado e complementos que informam lugar, modo e instrumento; já na segunda estrofe, esses elementos sintáticos sofrem um reordenação. Se fizermos uma correspondência sintática com os versos da primeira, teríamos a seqüência 3-4-1-5-2. Assim, Murilo simula no nível sintático a nova ordenação a que Gris submete as formas nos seus quadros.

Não se incorporou nenhuma palavra que remetesse às figuras pintadas por Gris. O que interessa é traçar um breve e certeiro juízo a respeito dessa pintura. Para tanto, os vocábulos caracterizam tanto a produção de Gris, quanto sugerem um tipo de poética que interessava, até certo ponto, a Murilo, ao compor a eliminação do excesso (pureza, concisão) e da espontaneidade (medida, pensada, simetria).

Apesar da longa temporada parisiense, coloca-se Gris como devedor e revelador do país natal, sujeito gramatical do poema. Uma Espanha "irracional", suposta visão do senso comum de países mais ponderados, seria negada pelas características da pintura cubista. Seguindo o paralelo entre a pintura e a poesia, poderíamos substituir o "irracional" por "surrealista", rótulo que quiseram selar na poesia de Murilo, mas que nesse momento vinha sendo questionado por outros parâmetros. Contudo, persistia a tentativa de unir as oposições, a partir da clareza dialética e do acordo.

Essa não é uma faceta definitiva da percepção estética de Murilo, faltando ainda o último poema de seu museu espanhol. Peça "viva", pois conheceu 
pessoalmente Joan Miró, "em Paris, Barcelona, Palma de Maiorca, Roma" (PCP, 1775). O contato com o artista catalão revela-se nas três litografias na coleção de artes plásticas do brasileiro, uma exibindo a data de 1958 e outra, uma dedicatória de $1963 .{ }^{316}$ Além do poema de Tempo espanhol, Miró rendeu mais um poema recolhido na coletânea em francês Papiers e um retrato relâmpago da $2^{a}$ série, datados respectivamente de 1969 e de 1973. Isso equivale a pelo menos 15 anos de reflexão a respeito do pintor, sem contar que provavelmente já lera o fundamental ensaio de Cabral, publicado no Brasil em 1952.

"Joan Miró" é o único poema da galeria muriliana em que não se menciona uma referência geogrática, e por extensão, histórico-cultural. Se nos anteriores os pintores representavam Espanha, Catalunha ou Castela, aqui o artista paira livre acima de países e regiões:

Soltas a sigla, o pássaro e o losango.
Também sabes deixar em liberdade
O roxo, qualquer azul e o vermelho.
Todas as cores podem aproximar-se
Quando um menino as conduz no sol
E cria a fosforescência:
A ordem que se desintegra
Forma outra ordem ajuntada
Ao real - este obscuro mito. (PCP, 618)

A poesia também aproximou Murilo e Miró, pois o pintor manteve fortes laços com a literatura, desde a escrita de poemas à criação de quadros poemas, passando pela participação na edição de livros. Na década de 20 em Paris, estabeleceu amizade com importantes poetas surrealistas, como Robert Desnos, Benjamim Péret e Paul Éluard, que Ihe abriram novas perspectivas, chegando a explorar em textos a escrita automática. Após o surrealismo, ambos ainda coincidiam nas preferências literárias, voltando-se aos grandes escritores místicos da literatura espanhola, San Juan de la Cruz e Santa Teresa de Jesús. Miró, que em 1942 atravessava uma etapa decisiva de sua obra, dividiu-se entre os místicos espanhóis e os franceses que inauguraram a poesia moderna: “(...) me enriqueci enormemente durante esse período de solidão. Lia todo o tempo san Juan de la Cruz, santa Teresa e poesia - Mallarmé, Rimbaud - . Era uma existência ascética:

${ }^{316}$ V. Anexos, Artistas plásticos espanhóis no acervo de Murilo Mendes (CEMM - Juiz de Fora). 
apenas trabalho."317 Utilizava inclusive as comuns antíteses que expressavam a experiência mística para descrever suas intenções na pintura: "Na verdade, o que busco é um movimento imóvel, algo que seria equivalente ao que se chama eloqüência do silêncio ou o que san Juan de la Cruz designava, acho, com as palavras 'música calada'”. ${ }^{18}$ A oposição mencionada em entrevista de 1959 pertence a $15^{\mathrm{a}}$ estrofe de Cántico:

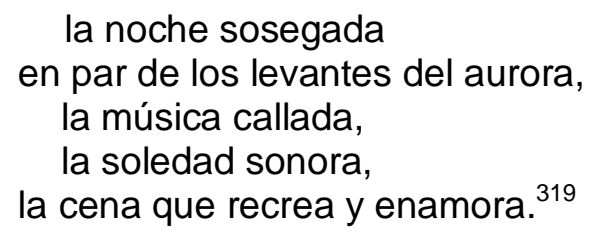

Quanto a Murilo, anotou, por exemplo, os “Avisos y setencias espirituales" de San Juan de la Cruz, sobretudo os que se referem às privações da alma, como o de número 352:

Reine en tu alma siempre un estudio de inclinarse, no a lo fácil, sino a lo más dificultoso; no a lo más gustoso, sino a lo más desabrido; no a lo más alto y precioso, sino a lo más bajo y despreciado; no a lo más, sino a lo que es menos; no a lo que es querer algo, sino a no querer nada, no a andar buscando lo mejor de las cosas sino lo peor. Deseando entrar por el amor de Jesuscristo en la desnudez, vacío y pobreza de cuanto hay en el mundo. [sublinhado por Murilo] ${ }^{320}$

No poema "São João da Cruz" de Tempo espanhol, publicado no mesmo ano da entrevista de Miró, explora esses princípios: "Viver: do seu silêncio se aprendendo."; "Para vir a ser tudo, é preciso ser nada."

Portanto, Murilo valoriza a intensa relação de Miró com a poesia na abertura do retrato-relâmpago - "Miró declara que não pode separar a poesia da pintura." (PCP, 1275) e nas justaposições "peinture-poésie miròïenne" e "peintre-poète" do poema de Papiers (PCP, 1597).

\footnotetext{
${ }^{317}$ ROWEL, Margit, org. Op. cit., p. 295-296.

${ }^{318}$ Idem, ibidem, 336.

319 SAN JUAN DE LA CRUZ. Poesía. 11 ${ }^{a}$ ed. Edição de Domingo Ynduráin. Madri: Cátedra, 2000, p. 252.

${ }^{320}$ SAN JUAN DE LA CRUZ. Obras escogidas. Edição de Ignacio B. Anzoátegui. $2^{\mathrm{a}}$ ed. Buenos Aires: Espasa Calpe, 1945, p. 119
} 
Ainda no terreno literário, Miró criou "títulos-poemas" para seus quadros: seguindo a lição surrealista, situa seres comuns, como a mulher ou o pássaro, em circunstâncias inusitadas. Os versos 4-6 do poema de Murilo - "Todas as cores podem aproximar-se/ Quando um menino as conduz ao sol/ E cria a fosforescência:" - não apenas metaforiza a invenção do pintor, como também recupera a atmosfera dos "títulos-poemas". Um deles, datado de 1954, refere-se ao brilho sob a luz do dia: "A festa dos círculos fosforescentes no nascimento do dia." ${ }^{\text {"21 }}$ No retrato-relâmpago, os "títulos-poemas" aparecem como confronto a nossa lógica: "Sabe que o mundo através de seus sistemas gastos impede por exemplo o pássaro de telegrafar à pedra; impede as estrelas de jogarem os dados; a formiga de pedir a palavra; um cachorro de puxar aquela moça por um cordel." (PCP, 1275).

Embora admire em Miró a dimensão onírica e libertária, Murilo não se atreve a Ihe colocar, como tampouco a si mesmo, a designação de surrealista: "Nem surrealista nem abstrato ortodoxo, escapa às etiquetas." (PCP, 1275). Da mesma forma o próprio Miró descartava as classificações:

O senhor ouviu falar de uma bobagem mais considerável do que a "abstração-abstração"? E me convidam a sua casa deserta, como se os signos que transcrevi sobre uma tela, desde o momento em que correspondem a uma representação concreta de meu espírito, não possuíssem já uma profunda realidade, não fizessem parte da realidade! Por outro lado, veja o senhor, concedo uma importância cada vez maior à matéria de minhas obras. Uma matéria rica e vigorosa me parece necessária para dar ao espectador esse golpe em pleno rosto que deve alcançá-lo antes de intervir a reflexão. Assim, a poesia, plasticamente expressada, fala sua própria linguagem. ${ }^{322}$

Como Cabral em Barcelona no final dos anos 40, Murilo pôde visitar a casa de Miró em Palma de Mallorca onde guardava os mais variados objetos que utilizava em suas obras: "(...) bulindo os olhos pequenos, maliciosos, me indica com o dedo os objetos de artesanato que eu mal consigo elogiar: ele me precede sublinhando diante de cada um : 'Es muy bonito...es precioso'. Não há dúvida.” (PCP, 1191).

Murilo, que cada vez mais dava importância ao trabalho artístico, reconhecia em Miró o "artesão refinado". Ao retomar no retrato-relâmpago a imagem do

${ }^{321}$ Entrevista de 1937 (ROWEL, Margit, org. Op. cit., p. 318). 
"menino" de Tempo espanhol, ressalta-a a partir de seu tradicional jogo de contrários: "Organizando a infância futura, consegue, em todos os casos, conciliar sonho e disciplina racional." (PCP, 1275). Os versos finais do poema relacionam-se com o depoimento acima de Miró, na medida em que não contrapõe sua pintura ao "real", este colocado sob suspeita como "obscuro mito". E novamente o retratorelâmpago desfaz em mão dupla uma suposta contradição: "Miró extrai o maravilhoso da coisa imediata; transforma em realidade a faixa onírica." (PCP, 1275).

\section{Da Espanha ao Brasil: Isabel Pons}

Embora o museu de Murilo termine com Miró em Tempo espanhol, ele prosseguiu um pouco mais em $A$ invenção do finito. Da poesia à prosa, surge, em meio a vários artistas italianos, a hispano-brasileira Isabel Pons Tranzo (1912), término da reflexão muriliana ao longo da história da arte espanhola.

Isabel Pons pertence a uma geração de artistas espanhóis, como Joan Ponç, Pedro Tort e Fernando Odriozola, que vieram para o Brasil e realizaram parte importante de sua obra. ${ }^{323}$ Nascida em Barcelona, desenvolveu uma produção figurativa, entre retratos e paisagens. Instalando-se no Rio de Janeiro em 1948, integrou-se não apenas ao cenário artístico brasileiro, mas a todo um contexto muito diferente de seu país natal: “(...) Acarioquei-me em meio a esta luminosidade preguiçosa, a esta bagunça deliciosa, em que tudo é tão espontâneo, às vezes inconseqüente até, mas indispensável para o meu oxigênio interior hoje (...)"324 $E$ tal atmosfera acompanhou a mudança decisiva em seu trabalho ao adotar em 1959 a técnica da gravura em metal: "Creio que nasci gravadora. Quando descobri a gravura, nunca mais quis saber da pintura. A gravura me depurou, fez-me muito mais refinada que a pintura, ensinando-me a trabalhar cada milímetro da obra, se bem que a pintura tenha enriquecido minha gravura, ao obrigar-me a nela incorporar

\footnotetext{
${ }^{322}$ Idem, ibidem, p. 214-215.

${ }^{323}$ V. CARVALHO, Agda. A imagem poética hispânica no Brasil: a contribuição pictórica de Isabel Pons, Pedro Tort, Fernando Odriozola e Joan Ponç. Tese de doutorado. ECA - USP, 2002.

${ }^{324}$ O Estado de São Paulo, 12 de junho de 1966 Apud CARVALHO, Agda. Op. cit., p. 31.
} 
a cor." ${ }^{\text {"325 }}$ A dimensão artesanal do trabalho de Isabel foi um dos grandes atrativos para Murilo.

O texto "Isabel Pons", como muitos outros de $A$ invenção do finito, anteriormente fez parte do folheto da exposição no Centro Culturale Italo-Brasiliano, em Milão, de 28 de janeiro a 13 de fevereiro de 1966, em tradução ao italiano de Giuliano Macchi. ${ }^{326}$ Vem com o lugar e a data de elaboração, "Roma, 1-1-1966", ou seja, quando Murilo encerrava os poemas de Convergência. Dessa maneira, a apreciação crítica sobre a artista pode ser relacionada à última coletânea do poeta. Sintomaticamente, a sua primeira seção é denominada de "Grafitos", termo utilizado para as inscrições na gravura de Isabel: "Não se trata de transcrever grafitos: eles se nos apresentam como protagonistas do muro, da ferrugem, da madeira." (PCP, 1331). Assim como Isabel, nesse momento Murilo cultivava uma "arte mais objetiva que subjetiva".

Por outro lado, o olhar de Murilo, habituado aos "fortes contrastes", identificou na produção de Isabel "finura e virilidade do traço", "emprego de tons ora secos, fechados, ora alegres", "austeridade e fantasia". As oposições anunciam a situação de uma artista entre dois países, Brasil e Espanha, compartilhada pelo autor de Tempo espanhol: "(...) às vezes se cruzam aqui a secura terrosa da nativa Espanha e a desenvoltura, o lirismo do Brasil, adotivo." (PCP, 1331). A "desenvoltura" e o "lirismo" ganhos pela obra de Isabel na vinda ao Brasil teriam sua contrapartida na "secura" e "concretude" adquiridas pela poesia de Murilo no embate com a Espanha.

No entanto, o poeta crítico não se limitou a essa conquista; constantemente instigado pela imaginação, entende que nas gravuras de Isabel "dá-se a passagem do natural ao super-real": "Ela faz da forja um cenário metafísico, sobrepondo-lhe uma segunda natureza." E repassa, de maneira poética, as principais obras de Isabel:

1 - "Atribui ao pássaro e ao inseto a monumentalidade que se diminui nos edifícios": por exemplo, Gafanhoto (1960) e Papagaio (1967);

2 - "O azulão transforma-se em habitante de uma constelação quadrada; em outra gravura ei-lo que vira uma astronave": Azulão (1961);

3 - "Pela força da matéria recriada o esgotado tema do 'noturno' é elevado a uma nova dignidade": Noturno (1961);

\footnotetext{
${ }^{325}$ Idem, ibidem, p. 36-37.

${ }^{326}$ Acervo da Biblioteca do MASP (Museu de Arte de São Paulo).
} 
4 - "um 'grande personagem' tanto pode pertencer ao reino mineral, como ao vegetal ou ao animal": refere-se à obra de mesmo título de 1962, reproduzida no folheto da exposição de $1966 .{ }^{327}$

E a última frase de Murilo também pode ser uma síntese para a série de artistas espanhóis expostos neste museu: "Sob o signo da metamorfose chegamos à contemplação de uma natureza domada; resultado da íntima aliança entre arte e artesanato."

${ }^{327}$ V. Anexos, Imagens. 


\section{CAPÍTULO 5: Paisagens e figuras da Espanha de Cabral}

A Espanha de Cabral é mais a da "paisagem com figuras", com toureiros, bailarinas e cantores de flamenco, do que a dos livros e das obras de arte. Nesse reduzido repertório de temas, os elementos de uma Espanha "exótica" ou "folclórica" passaram a ancorar firmemente um projeto poético. A partir de Paisagens com figuras, quase todas as coletâneas do poeta incorporaram a temática espanhola, recebendo sua síntese em Sevilha andando (1990). Essa constância estimulou seleções como a de Ángel Crespo e Pilar Gómez Bedate, Poemas sobre España de João Cabral de Melo Neto (1964) $)^{328}$ e a da editora Nova Fronteira, Poemas sevilhanos (1999).

Propomos para este capítulo três eixos para a análise das imagens da Espanha na poesia cabralina. O primeiro deles versa sobre a paisagem, atravessando Castela, Catalunha, Andaluzia, e fixando-se em Sevilha. O apreço pela paisagem espanhola dialoga com a chamada Geração de 98 e seus sucessores, que colocaram em circulação na Espanha esse parâmetro. Depois, exploramos a poesia dedicada à tauromaquia e ao flamenco, conjuntos relevantes não apenas na lírica em língua portuguesa, mas mesmo em relação à espanhola. Por último, centramo-nos nos poemas que abordam a religiosidade espanhola nas três últimas coletâneas de Cabral - Agrestes (1985), Crime na calle Relator (1987) e Sevilha andando (1990) - , provocações tardias a sua confissão, na carta a Murilo de 1959, de apenas tratar do aspecto material da Espanha.

\section{Paisagem de Espanha}

\subsection{A secura de Castela e do Nordeste}

Ao se deparar com a paisagem espanhola, Cabral redescobriu a nordestina: "O meu primeiro posto no exterior (e meu primeiro contato com o exterior) foi Barcelona, que está na Catalunha. Eu ia muitas vezes a Madri, isto é, atravessava

${ }^{328}$ V. Anexos, Traduções da obra de João Cabral de Melo Neto na Espanha. 
Aragão e a Mancha. Aí encontrei a secura e a essencialidade do sertão nordestino." 329 A impressão deixada fez com que a Espanha ingressasse como tema na sua obra com um livro que chamou de Paisagens com figuras, escrito entre 1954 e 1955, sete anos depois do encontro inicial, quando teve que retornar ao Brasil acusado de subversão. "Memórias" precoces, a distância motivou o poeta a recuperar nos versos os espaços percorridos.

O termo "paisagem" já aparecera nas duas primeiras partes de O cão sem plumas, denominadas "Paisagem do Capibaribe". Além de prestar contas à tradição do romance nordestino da década de 30, a partir de Paisagens com figuras Cabral estabelecia nexos com uma vertente inaugurada por escritores da literatura espanhola conhecidos como Geração de 98, Azorín, Miguel de Unamuno, Antonio Machado, entre outros. No começo do século XX, abalados pelo desastre da guerra com os Estados Unidos e pela perda das últimas colônias em 1898, promoveram a discussão de uma "essência" da Espanha. Para isso, voltaram-se à paisagem e ao homem que a habitava, especialmente a região de Castela, núcleo formador da nação, segundo a visão deles. A valorização do espaço levou Azorín a afirmar que "a base do patriotismo é a geografia". ${ }^{330}$ Embasados pelo determinismo de Taine, consideravam que as condições físicas do lugar imprimiam traços no homem. Por isso, são sintomáticos títulos como Paisajes (1902), de Unamuno, e España. Hombres y paisajes (1909), de Azorín. Tendência que continuou, pois Gerardo Diego publicou um Paisaje con figuras no mesmo ano das Duas águas de Cabral, 1956. ${ }^{331}$ Diego e Cabral, não por acaso, traziam um gênero de pintura em seus títulos, refletindo que literatura e artes plásticas haviam compartilhado objetivos, como aponta María del Carmen Pena no estudo Pintura de paisaje e ideología. La generación de 98:

Pintura y literatura habían de coincidir en la búsqueda o la invención de un ideal perdido, que en ocasiones se tornaba amargo y descarnado al poner de relieve una tierra seca y unos habitantes pobres ligados a los ancestros más oscuros, mientras que en otras ocasiones se cargaba de un lirismo evasivo penetrado todo él

\footnotetext{
${ }^{329}$ Entrevista a Veja. 28 de junho de 1972, p. 4.

${ }^{330}$ Apud RAMSDEN, Herbert. "El problema de España" In Historia y crítica de la literatura española. Francisco Rico, org. v. 6. Modernismo y 98. José-Carlos Mainer, org. Barcelona: Crítica, 1980, p. 2026.

${ }^{331}$ Essa observação devo ao Prof. Augusto Massi.
} 
de un claro neorromanticismo: en ese sentimiento se formaría gran parte del paisaje del 98, con sus modelos descriptivos cargados de melancolía, de sobriedad (...). ${ }^{332}$

O cenário de uma Espanha basicamente rural que esses autores tinham diante de si não era muito diferente daquele que Cabral deixara em Pernambuco nos anos 40. Por outro lado, os centros urbanos, ao contrário de muitos poetas modernos, não despertaram o interesse do poeta brasileiro: nem o Rio de Janeiro nem Barcelona, por exemplo, comparecem em sua poesia. E foi o campo desolado e árido de Castela que o fez recordar o Nordeste brasileiro.

Como desde o início de sua estada espanhola Cabral percorreu a história da literatura espanhola, é inevitável que tenha consultado os escritores da Geração de 98. Ao analisar os poemas de Paisagens com figuras, percebemos que eles podem ter-Ihe fornecido alguns princípios descritivos. A paisagem cabralina não é apenas memória da retina, mas também da leitura.

A primeira paisagem espanhola, e por extensão, primeiro poema sobre a Espanha na obra de Cabral, é "Medinaceli" (Terra provável do autor anônimo do Cantar do Mio Cid). Recorre, pois, ao poema fundador da literatura espanhola para inaugurar essa vertente. Anteriormente, a descrição espacial no Poema de Mio Cid teria sido uma das referências na composição d'O rio. Tomemos, por exemplo, uma passagem do primeiro canto, em que Cid cavalga por diversos lugares, onde homens ingressam ao seu grupo:

Otro dia mañana pienssa de cavalgar.

Ixiendos va de tierra el Campeador leal;

de siniestro Sant Estevan -una buena çipdad-

de diestro Alion las torres que moros las han,

passo por Alcobiella que de Castiella fin es ya,

la Calçada de Quinea iva la traspassar,

sobre Navas de Palos el Duero va pasar,

a la Figeruela mio Çid iva posar.

Van acogiendo yentes de todas partes. ${ }^{333}$

\footnotetext{
${ }^{332}$ Madri: Taurus, 1998, p. 54.

${ }^{333}$ Versos 394-403 do Cantar I. Poema de Mio Cid. $18^{\mathrm{a}}$ ed. Edição de Colin Smith. Madri: Cátedra, 1993, p. 150-151.
} 
Desta vez, acompanhemos um fragmento d'O rio, "Do Apolinário a Paço Fundo":

\author{
Para o mar vou descendo \\ por essa estrada da ribeira. \\ A terra vou deixando \\ de minha infância primeira. \\ Vou deixando uma terra \\ reduzida à sua areia, \\ terra onde as coisas vivem \\ a natureza da pedra. \\ À mão direita os ermos \\ do Brejo da Madre de Deus, \\ Taquaritinga à esquerda, \\ onde o ermo é sempre o mesmo. \\ Brejo ou Taquaritinga, \\ Mão direita ou mão esquerda, \\ vou entre coisas poucas \\ e secas além de sua pedra. (SA, 91)
}

Significativo indício da leitura contumaz do Poema de Mio Cid, há uma grande semelhança das expressões "Ixiendos va de tierra" e "A terra vou deixando". Os topônimos sucedem-se, realçando-se, em meio a poucas descrições, suas sonoridades e sugestões semânticas. Reforça-se a incorporação do épico espanhol na apresentação do binômio espacial: "de siniestro Sant Estevan -una buena çipdad-/ de diestro Alion las torres que moros las han,"; "À mão direita os ermos/ do Brejo da Madre de Deus,/ Taquaritinga à esquerda,/ onde o ermo é sempre o mesmo.".

Durante a viagem, como ao grupo de Cid "Van acogiendo yentes de todas partes.", o rio Capibaribe é acompanhado pelos retirantes da seca. Até atingirem seus destinos, percorrem paisagens semelhantes. Cid e seus companheiros enfrentam os campos de Castela, onde "La tierra es angosta e sobejana de mala" ${ }^{334}$, enquanto o Capibaribe segue "entre coisas poucas/ e secas além de sua

${ }^{334}$ Verso 46 do Cantar I. Idem, ibidem, p. 166. 
pedra." A aspereza não é apenas a do ritmo, mas também caracteriza a natureza representada. A equiparação entre Nordeste-Castela, iniciada em Paisagens com figuras, já se insinuava n'O rio.

Os escritores espanhóis também haviam encontrado no poema épico um grande exemplo de figuração da paisagem espanhola. Azorín, por exemplo, no importante ensaio "El paisaje en la poesía”, confirma essa referência: “(...) En el Poema del Cid aparecen nombres de villas, lugares y campiños; de tarde en tarde el poeta, en un verso, con una indicación sumarísima, compendiosa, nos hace columbrar un paisaje. Pero como en la llanura castellana, monótona y calcinada, tienen un valor extraordinario, una vida profunda, unos chopos, unos olmos o unos alisos que la vista divisa en la extensión inmensa, así en la llanura del Poema del Cid estas breves indicaciones de paisajes adquieren una significación considerable." ${ }^{335}$ Mas, como Cabral propõe, trata-se de uma "paisagem com figuras", ou melhor, com homens; nesse sentido, Unamuno sugere que a falta de água condiciona toda a existência: "Se ha dicho que en la literatura castellana apenas hay paisajes, pero sin demasiada paradoja cabría retrucar que apenas hay en ella más que paisaje, que los hombres del Poema del Cid o los del Romancero son como encinas o como rocas, de recio leño o de piedra tierna y de un paisaje sin agua. Pues el agua es como la conciencia del paisaje; (...) Pero en las tierras sin agua, hasta los hombres no son más que paisajes, pintura de Dios. ¡Pero que pintura!”336

No seu poema, Cabral baseia-se na hipótese de estudiosos como Ramón Menendez Pidal, de que o autor do Poema de Mío Cid teria nascido na cidade de Medinaceli, um dos palcos da ação do épico:
Do alto de sua montanha numa lenta hemorragia do esqueleto já folgado a cidade se esvazia.
Puseram Medinaceli bem na entrada de Castela como no alto de um portão se põe um leão de pedra.

\footnotetext{
${ }_{335}$ Clásicos y modernos (1913) In Obras escogidas. v. 2. Ensayos. Edição de Miguel Ángel Lozano Marco. Madri: Espasa Calpe, 1988, p. 886.

${ }^{336}$ Andanzas y visiones españolas (1922) In Obras completas. v. 1. Paisajes y ensayos. Madri: Escelicer, 1966, p. 495.
} 


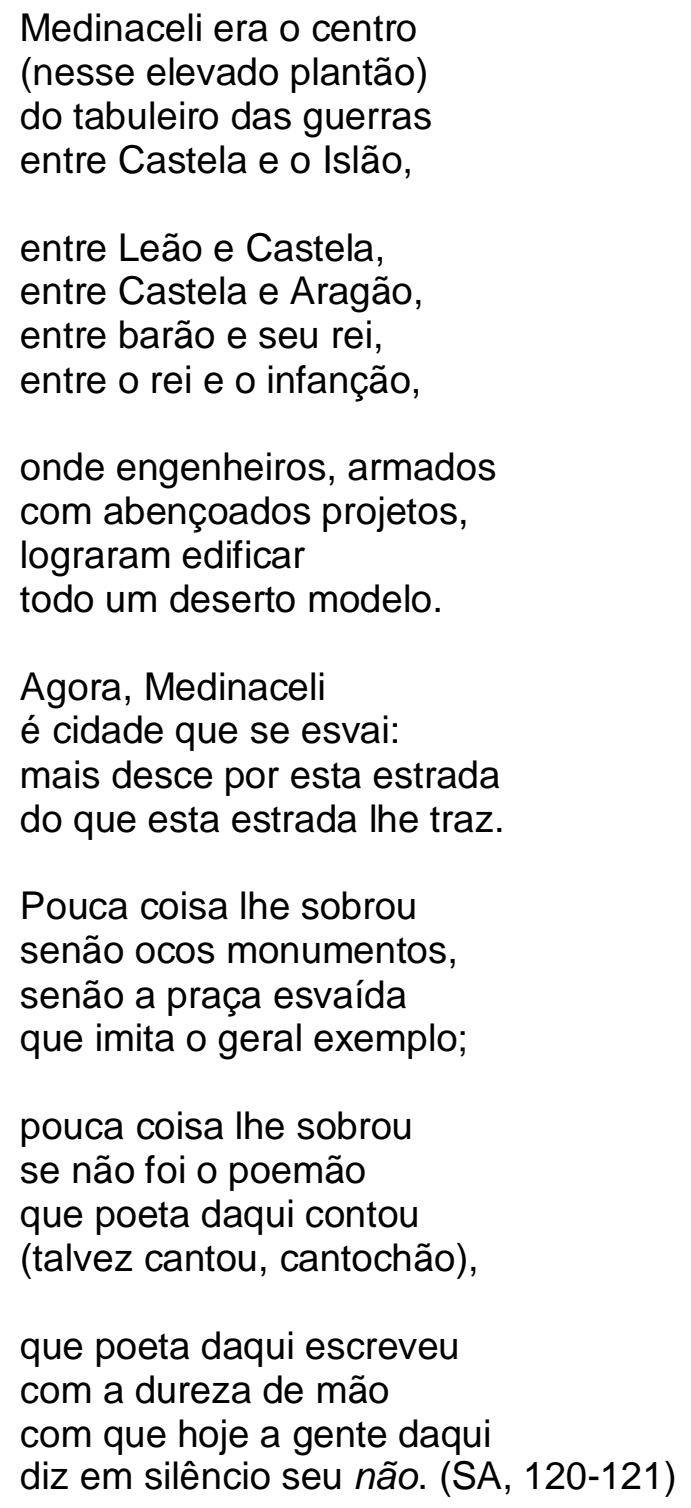

Os pontos em comum entre Castela e o Nordeste, implícitas em 0 rio, tornam-se mais claras. O sertão pernambucano, como Medinaceli, vive um processo de esvaziamento, como já aparecera em O rio: "Por trás do que lembro, / ouvi de uma terra desertada,/ vaziada, não vazia,". O "esvaziar" não é apenas de pessoas, mas também de significados. Entre a $2^{\mathrm{a}}$ e a $4^{\mathrm{a}}$ estrofe, o poema volta-se para 0 passado, no qual "Medinaceli era o centro". Em contraste com o imobilismo e o vazio predominantes, sucedem-se nos versos o movimento e a coletividade de reinos, regiões e forças políticas das lutas da História. E, na $6^{a}$ estrofe, retorno à atualidade, o verbo de "esvaziar" passa a "esvair", intensificando a noção de desaparecimento, de esgotamento daquele período. 
$\mathrm{Na} 5^{\mathrm{a}}$ estrofe, adentra-se a cidade, na tentativa de encontrar vestígios do que aconteceu, mas "Pouca coisa the sobrou/ senão ocos monumentos". A escassez, traço forte a ligar Castela e o Nordeste, revela-se no poema a partir da preposição "senão", logo confrontada pela condicional homófona "se não", singularizando o que de mais importante restou da antiga Medinaceli. O "poemão" vale mais que os "ocos monumentos"; o monumento literário sobrepõe-se à paisagem, até esse ponto "sem figuras", quase uma "cidade fantasma". Por sua vez, o signo "dureza" correlaciona paisagem-homem-obra: um poema com a "dureza" de forma e de conteúdo como o Mio Cid fora realizado "com a dureza de mão" de um autor, que por sua vez nasceu em uma cidade "dura", assim caracterizada na imagem do "leão de pedra".

O verso "com a dureza de mão" conforma duas dimensões temporais, tanto a forma de escrever do autor medieval quanto a severidade do trato pessoal "com que hoje a gente daqui/ diz em silêncio seu não." O "silêncio", que domina a cidade esvaziada, no verso final remete à censura que cala vozes dissonantes, experimentada durante décadas na Espanha franquista. Dessa maneira, o não expressa um tipo de resistência, não verbalizado, mas de qualquer modo percebido, de discordância com a ordem vigente.

Antonio Machado, no poema "A orillas del Duero", de Campos de Castilla (1907-1917) - no qual, para Azorín, "a paisagem adquire sua plenitude, seu cabal desenvolvimento"337 - também contrastara um passado guerreiro da figura de Mío Cid com a decadência atual:

¡Oh, tierra triste y noble, la de los altos llanos y yermos y roquedas, de campos sin arados, regatos ni arboledas; decrépitas ciudades, caminos sin mesones, y atónitos palurdos sin danzas ni canciones que aún van, abandonando el mortecido hogar, como tus largos ríos, Castilla, hacia la mar!

Castilla miserable, ayer dominadora, envuelta en sus andrajos desprecia cuanto ignora. ¿Espera, duerme o sueña? ¿La sangre derramada recuerda, cuando tuvo la fiebre de la espada? Todo se mueve, fluye, discurre, corre o gira; cambian la mar y el monte y el ojo que los mira. ¿Pasó? Sobre sus campos aún el fantasma yerra de un pueblo que ponía a Dios sobre la guerra.

La madre en otro tiempo fecunda en capitanes, madastra es hoy apenas de humildes ganapanes.

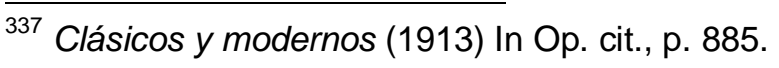


Castilla no es aquella tan generosa un día, cuando Myo Cid Rodrigo el de Vivar volvía, ufano de su nueva fortuna, y su opulencia, $(\ldots)^{338}$

Seguro leitor de Antonio Machado, Cabral aproximou-se em O rio da imagem do abandono da terra em direção ao litoral: "que aún van, abandonando el mortecido hogar,/ como tus largos ríos, Castilla, hacia la mar!". Além disso, o autor de Campos de Castilla enveredou pela "paisagem com figuras", trazendo toda a penúria e sofrimento do homem, como no poema "Por tierras de España":

\section{(...)}

Hoy ve a sus pobres hijos huyendo de sus lares;

la tempestad llevarse los limos de la tierra por los sagrados ríos hacia los anchos mares; y en páramos malditos trabaja, sufre y yerra.

Es hijo de una estirpe de rudos caminantes, pastores que conducen sus hordas de merinos a Extremadura fértil, rebaños trashumantes que mancha el polvo y dora el sol de los caminos.

Pequeño, ágil, sufrido, los ojos de hombre astuto, hundido, recelosos, movibles; y trazadas cual arco de ballesta, en el semblante enjuto de pómulos salientes, las cejas muy pobladas. ${ }^{339}$

Voltando a Paisagens com figuras, o poema "Vale do Capibaribe" funciona como o contraponto pernambucano a "Medinaceli":
Vale do Capibaribe
por Santa Cruz, Toritama:
cena para cronicões,
para épicas castelhanas.
Mas é paisagem em que nada ocorreu em nenhum século (nem mesmo águas ocorrem na língua dos rios secos).
Nada aconteceu embora a pedra pareça extinta e os ombros do monumento finjam história e ruína.

\footnotetext{
${ }^{338}$ MACHADO, Antonio. Poesías completas. Edição de Manuel Alvar. Madri: Espasa Calpe, 2003, p. 152.

${ }^{339}$ Idem, ibidem, p. 153-154.
} 
(De que seriam ruína, de que já foram paredes?

Do forno em que o deus da seca acendia a sua sede?)

E também nada acontece: raro o pobre romanceiro da cruz na estrada, mais raro o crime não rotineiro

com acentos de gesta (ou as façanhas cangaceiras) que o vale possa ecoar e seja cantado em feira.

No mentido alicerce de morta civilização a luta que sempre ocorre não é tema de canção.

É a luta contra o deserto, luta em que sangue não corre, em que o vencedor não mata mas aos vencidos absorve.

É uma luta contra a terra e sua boca sem saliva, seus intestinos de pedra, sua vocação de caliça,

que se dá de dia em dia, que se dá de homem a homem, que se dá de seca em seca, que se dá de morte em morte. (SA, 125-126)

Logo na primeira estrofe, a conexão Nordeste-Castela retorna com mais força: o Vale do Capibaribe, enquanto "cena para cronicões/ para épicas castelhanas", leva-nos a compará-lo à paisagem espanhola onde se desenrolavam suas ações. A partir daí, o poema lança aproximações e distanciamentos entre os dois lugares. Diferentemente da turbulenta e heróica história de que Medinaceli foi o palco, este Vale "é paisagem em que nada/ ocorreu em nenhum século". Por outro lado, a pedra que parece "extinta" e os "ombros do monumento" simulam "história e ruína" à maneira dos "ocos monumentos" verdadeiros de Medinaceli. Entre parênteses, levanta-se a hipótese duvidosa de uma origem mítica que dignificasse a região: talvez teriam sido "paredes" do "forno em que o deus da seca/ Acendia sua sede". Para um poeta que se voltava às coisas do mundo, a concessão ao plano imaginário pode ser entendida como um irônico afastamento de quem sabia da 
verdadeira causa - a qual, embora não tão longínqua, tinha já sua história - do descaso ecológico e político pelo Nordeste brasileiro. No entanto, o certo é que no presente "nada acontece", como na esvaziada Medinaceli. Exceção para os "raros" fatos dignos de alguma nota, ou melhor, canto: "raro o pobre romanceiro/ da cruz na estrada, mais raro o crime não rotineiro// com acentos de gesta (ou/ as façanhas cangaceiras)/ que o vale possa ecoar/ e seja cantado em feira." Os vínculos entre os dois espaços impõem-se para além da paisagem, fincando raízes na cultura, pois os cantares populares nordestinos devem muito à matriz ibérica. Em "Vale do Capibaribe", porém, é "raro" e "pobre" frente ao "poemão" do Mío Cid que ainda justifica a lembrança de Medinaceli.

No final de ambos os poemas, a "figura" da paisagem aparece como resistência à adversidade, contra a ditadura em "Medinalceli", contra a morte em "Vale do Capibaribe". O que não seria "tema de canção" ganha espaço em poetas como Antonio Machado e João Cabral.

O poema final de Paisagens com figuras contrasta as "Duas paisagens" que permeiam o livro, Espanha e Pernambuco:

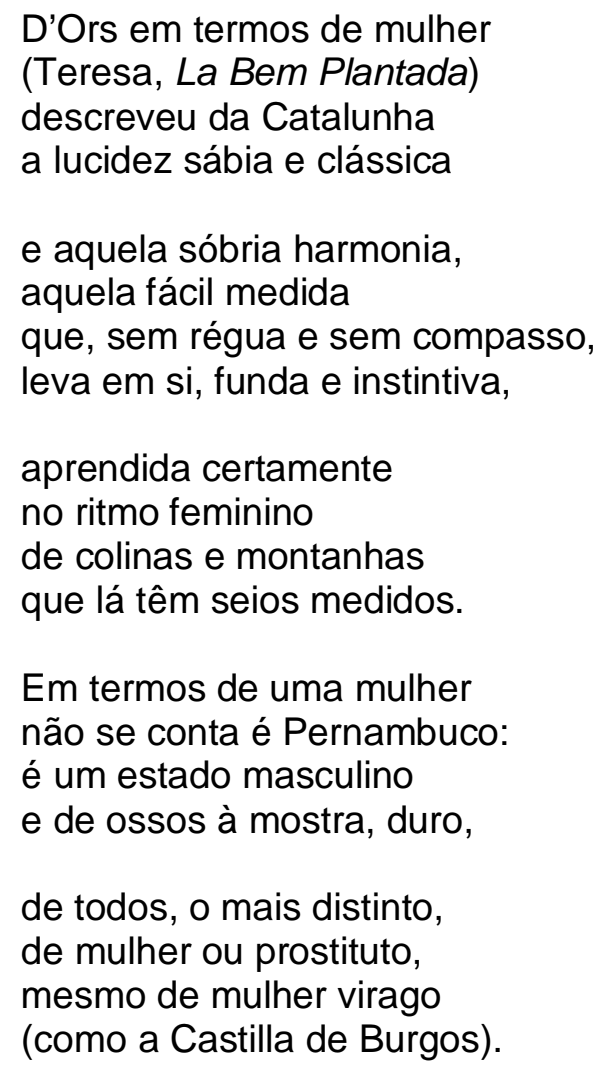




\begin{abstract}
Lúcido não por cultura,
Medido, mas não por ciência:

sua lucidez vem da fome

a medida, da carência,

e se for preciso um mito

para bem representá-lo

em vez de uma Ben Plantada

use-se o Mal Adubado. (SA, 140-141)
\end{abstract}

O poema se inicia com uma referência literária, não declarada nos anteriores, mas que acima tentamos recuperar: vale-se do romance La bem Plantada, de Eugenio D'Ors, que apresenta o símbolo da catalanidade frente ao castelhano, especialmente aos autores da Geração de $98 .{ }^{340}$ Ao comentar o nome da protagonista, Teresa, contrapõe as duas tradições culturais, base das "Duas paisagens" de Cabral:

Teresa es un nombre castellano. Allá es un nombre místico, ardiente, amarillo, áspero. Es un nombre que rima con todas estas cosas de que ahora se habla tanto: "la fuerte tierra castellana, "el paisaje austero, desnudo, pardo", "los hombre graves vestidos de fosca bayeta" "Avila de los caballeros" "el alma ardiente de la santa" "Zuluaga, pintor de Castilla" "El retablo del mar" "La mística sensualidad, esposa de Cristo o mujerdeca". Ya sabéis, ¿no? qué linaje de cosas quiero decir.

Para llegar el mismo nombre a nuestra tierra, y de pasarlo por la boca de otra manera, adquiere otro sabor. Un sabor a un mismo tiempo dulce y casero, caliente y sustancioso como el de la torta azucarada. Teresa es un nombre que tiene manos capaces de la caricia, de la labor y del abrazo. Teresa es a la vez un nombre modesto y muy fino. Teresa es un nombre hacendoso. Teresa es un nombre para responder, con voz de contralto: "Servidora, me llamo Teresa". 341

A paisagem catalã foi abordada nos poemas "Campo de Tarragona" e "Paisagem tipográfica" ${ }^{342}$, anunciando a perspectiva de D'Ors. Paisagens que passam pela codificação do homem, que podem ser "lidas": no campo de Tarragona,

\footnotetext{
${ }^{340}$ ARANGUREN, José Luis L. "Sentido ético de las ficciones novelescas orsianas" In Historia y crítica de la literatura española. Francisco Rico, org. v. 7. Época contemporánea. 1914-1939. Víctor G. de la Concha, org. Barcelona: Crítica, 1984, p. 60-65.

${ }^{341}$ D'ORS, Eugenio. La bien plantada. Trad. Rafael Marquina, 1911, p. 40-41.

${ }^{342}$ V. comentário a esses poemas no Capítulo 3.
} 
como uma "mapa", "a face da Catalunha/ é mais clássica de ler.", enquanto os "bairros industriais" e as "vilas" acompanham a ordenação da tipografia.

Se D'Ors opõe Catalunha e Castela, Cabral troca até certo ponto os termos ao trazer Catalunha e Pernambuco, pois já sabemos que, no âmbito de Paisagens com figuras, quando diz Nordeste também está se referindo a Castela. Tanto que no poema esclarece entre parênteses: "(como a Castilla de Burgos)." O poeta brasileiro também toma de D'Ors a imagem da mulher para representar uma paisagem, que como veremos a seguir, seria recorrente. Mas como se trata de diferenças entre as "Duas paisagens", Catalunha é mulher frente ao "estado masculino" de Pernambuco. A paisagem e homem "descarnados" pela fome e pela seca mostram-se "ossos à mostra, duro", variante nordestina da "tierra esquelética y sequiza" de Antonio Machado. ${ }^{343}$ E o "mito" de D’Ors, "plantado" na agricultura para valorizar o catalão, é subvertido por Cabral como o "Mal Adubado", para figurar negativamente a fome e a carência do nordestino.

\subsection{Andaluzia e "ainda, ou sempre, Sevilha"}

Cabral descobriu outra paisagem para além da amplidão e secura castelhana, ativando uma complexa relação entre regiões da Espanha e de Pernambuco:

(...) Vivi na Espanha, sem ter podido conhecer Andaluzia, de 1947 a 1950, quando fui para Londres. Em 1956 voltei para a Espanha e, desta vez, para Sevilha, na Andaluzia. A Andaluzia é, do ponto de vista agrícola, a região mais fértil da Espanha. E foi a região do mundo com que mais me identifiquei: devo lembrar que sou pernambucano da Zona da Mata, zona fértil, e não do sertão, embora me identifique melhor com o sertão seco, assim como tenho mais afinidade com o alagoano Graciliano Ramos do que com meu primo Gilberto Freyre. Os meus sentimentos entre a Andaluzia e a Mancha e Aragão têm a mesma ambigüidade que existe no meu eu pernambucano, entre o homem de Zona da Mata, fértil, e o do sertão, seco, que conheço apenas de passagem, mas que me marcou profundamente. Há uma afinidade entre a Mancha e Aragão e o nordeste seco. Mas nenhuma entre o nordeste da Zona da Mata e a Andaluzia. ${ }^{344}$

\footnotetext{
${ }^{343}$ Verso 24 de "Un loco" de Campos de Castilla (MACHADO, Antonio. Op. cit., p.163).

${ }^{344}$ Entrevista a Veja. 28 de junho de 1972, p. 4.
} 
A distinção entre as duas regiões compõe a quarta parte do poema "Pernambucano em Málaga", de Serial:

A cana doce de Málaga

dá dócil, disciplinada:

dá em fundos de quintal

e podia dar em jarras.

Falta-Ihe é a força da nossa,

criada solta em ruas, praças:

solta, à vontade do corpo,

nas praças das grandes várzeas. (SA, 292)

Por outro lado, a identificação foi total com a Andaluzia, e mais especificamente, Sevilha, já que de Quaderna (1960) a Sevilha andando (1990) pouco se deteve nas demais comunidades espanholas. Se Castela é o masculino, Andaluzia, por sua vez, marca o feminino, tema incorporado à obra cabralina a partir de Quaderna. Em "Baixa Andaluzia", de A educação pela pedra, dá-se a medida do entusiasmo do poeta acostumado a caatingas e a mesetas:

Nessa Andaluzia coisa nenhuma cessa completamente, de ser da e de terra; e de uma terra dessa sua, de noiva, de entreperna: terra de vale, de coxa; donde germinarem ali pelos telhados, e verdadeiros, jardins de jaramago: a terra das telhas, apesar de cozinha, nem cessa de parir nem a ninfomania. De parir flores de flor, não de urtiga: os jardins germinam sobre casas sadias, que exibem os tais jardins suspensos e outro interior, no pátio de dentro, e outros sempre onde da terra incasta dessa Andaluzia, terra sem menopausa, que fácil deita e deixa, nunca enviúva, e que de ser fêmea nenhum forno cura.

\section{2}

A terra das telhas, apesar de cozida, não cessa de dar-se ao que engravida: segue do feminino; aliás são do gênero as cidades ali, sem pedra nem cimento, feitas só de tijolo de terra parideira de que herdam tais traços de femeeza. (Sevilha os herdou todos e ao extremo: a menos macha, e tendo pedra e cimento). (EPD, 35-36) 
Após discorrer sobre toda uma região, os versos finais em parênteses revelam a cidade mais fêmea. Em lugar da paisagem natural predominante, Cabral passou a freqüentar um determinado espaço urbano. Tal visitação vinha desde $O$ rio, no qual denunciou o "que existe por debaixo/ do Recife contado em Guias", alusão ao Guia prático, histórico e sentimental da cidade do Recife (1934), de Gilberto Freyre. Embora o Recife seja menos constante do que Sevilha em sua obra, nos poemas "Coisas de cabeceira, Recife" e "Coisas de cabeceira, Sevilha" ( $A$ educação pela pedra), alinhou as duas cidades, a natal e a adotiva, "em uma prateleira na memória".

Além do afetivo, Sevilha possibilitou a Cabral uma teoria da cidade, não apenas para compreendê-la, mas também para apresentá-la como modelo para outras cidades, chegando a propor "Sevilhizar o mundo" (Sevilha andando). Se anteriormente estabelecera um diálogo com os escritores da Geração de 98 e sua contrapartida catalã na figura de Eugenio D'Ors para formular sua teoria da paisagem, no caso sevilhano, divergia do escritor Joaquín Romero Murube, recordado no poema "O segredo de Sevilha" de Sevilha andando:

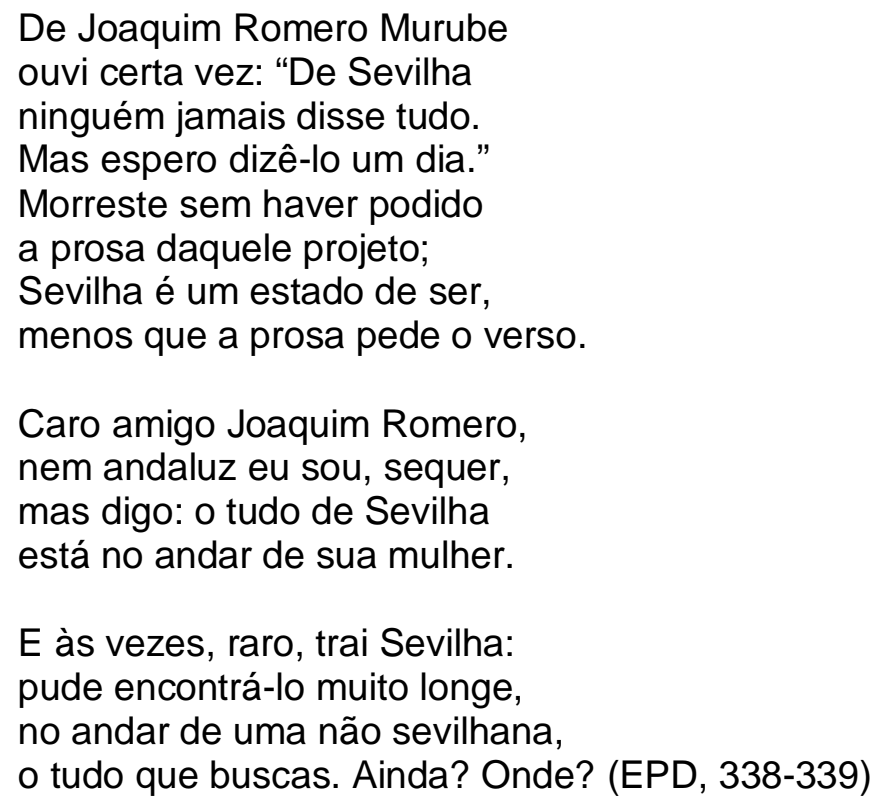

Romero Murube ocupou o cargo de diretor e conservador do Alcázar de Sevilha de 1934 a 1969, ano da sua morte, tendo recebido personalidades da política e da cultura, entre elas o poeta diplomata brasileiro que esteve na cidade de 1956 a 1958 e de 1962 a 1964. Componente do grupo Mediodía, vertente sevilhana 
da Geração de 27, escreveu seis livros de poesia até 1948. A partir de então, dedicou-se cada vez mais à sua obra ensaística, na qual Sevilha tornou-se o tema central. ${ }^{345}$ Como está na $1^{\text {a }}$ estrofe do poema de Cabral, Romero Murube idealizava uma grande obra sobre a sua cidade: "Mi mayor orgullo sería hacer un libro definitivo sobre Sevilla. Como esta ciudad es la menos conocida de todas las ciudades españolas, aunque el vulgo crea lo contrario, sé lo difícil de mi empeño. Pero no creo que haya nada bueno literariamente por los cauces de la facilidad y de lo cómodo. He de ir a eso - a mi libro sobre Sevilla difícil - y en eso trabajo, dudo, sufro, sueño, fracaso y me divierto."346

De acordo com ele, o "segredo de Sevilha" seria indefinível: "Sevilla en la Literatura, en el Arte, será siempre una fina interrogación desafiadora. Hay ciudades - Venecia, Toledo, Alejandría - cuyo espíritu ha quedado para siempre fijado en las páginas de algunos escritores. Con Sevilla esto no es posible, porque repugna a la esencia misma, al alma misteriosa de la ciudad. El secreto de Sevilla es una constante mutación, es un fluir inextinguible de algo recóndito que moviliza y mantiene estas sucesiones, siempre llenas de igual vitalidad y dinamismo."347 Ao contrário, Cabral propõe captar esse "segredo" no andar da sevilhana, que inclusive, de tão característico, poderia até mesmo ser identificado em uma não sevilhana.

Mas a teoria da cidade de Cabral começara em Quaderna. No poema singelamente intitulado "Sevilha", o símile principal é cidade-roupa. Já a $1^{\text {a }}$ estrofe da parte 1 mostra a singularidade de Sevilha frente a outras cidades:

\section{A cidade mais bem cortada que vi, Sevilha: \\ cidade que veste o homem sob medida. (SA, 236)}

$\mathrm{Na}$ parte 2, expõe a vantagem sevilhana em relação às cidades modernas, desproporcionais à dimensão humana:

\footnotetext{
345 Compõe-se de Sevilla en los labios (1938), Discurso de la mentira (1943), Memoriales y divagaciones (1959), Lejos y en las manos (1959) e Los cielos que perdimos (1964).

${ }^{346}$ Apud CORTINES, Jacobo e LAMILLAR, Juan. "Belleza ordenada" In MURUBE, Joaquín Romero. Obra selecta. v. 1. Silencios de Andalucía (Lírica y Narrativa). Sevilha: Fundación José Manuel Larra, Diputación de Sevilla, Ayuntamineto de Sevilla e Fundación El Monte, 2004, p. XXIII.
} 


\section{Nem com os gestos do corpo} nunca interfere,

qual roupa ou cidade que é

cortada em série. (SA, 237)

Quanto à parte 3, uma série de imagens intensificam a intimidade do homem com Sevilha: casa - quarto - roupa - camisa. A interiorização crescente atinge a do contato sexual:

$$
\begin{aligned}
& \text { E mais que intimidade } \\
& \text { até com amor } \\
& \text { como um corpo que se usa } \\
& \text { pelo interior. (SA, 238) }
\end{aligned}
$$

O advérbio de tempo ainda na estrofe final sugere a permanência de um antigo modelo de cidade ao alcance do homem:

$$
\begin{aligned}
& \text { sevilhano em quem se encontra } \\
& \text { ainda o gosto } \\
& \text { de ter a vida à medida } \\
& \text { do próprio corpo. (SA, 238) }
\end{aligned}
$$

A correlação cidade-corpo, ou melhor ainda, cidade-mulher, permeia os poemas seguintes sobre Sevilha, principalmente a última coletânea. E essa associação pode inclusive acompanhar a poética cabralina, como no poema "Retrato" (Sevilha andando):

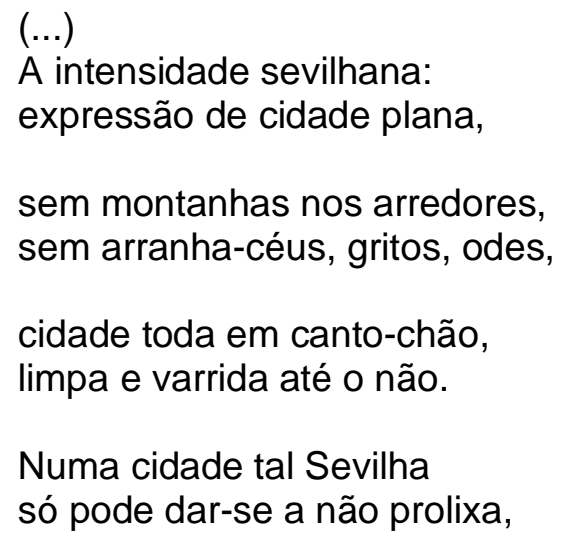

\footnotetext{
347 Discurso de la mentira In MURUBE, Joaquín Romero. Obra selecta. v. 2. Los cielos perdidos (Prosa ensayística). Sevilha: Fundación José Manuel Larra, Diputación de Sevilla, Ayuntamineto de Sevilla e Fundación El Monte, 2004, p. 84.
} 
a que prefere a linha pura:

nela lhe basta, o que é nervura;

(...)

$(\mathrm{EDP}, 347)$

Nesse aspecto, Castela e Sevilha irmanam-se pela escassez, distintas de paisagens exuberantes e cidades gigantescas.

O poema final de Sevilha andando e, por extensão, de toda a obra de Cabral, é o significativo "Sevilha e o progresso", síntese de sua teoria da cidade:

Sevilha é a única cidade

que soube crescer sem matar-se.

Cresceu do outro lado do rio,

Cresceu ao redor, como os circos,

conservando puro seu centro,

intocável, sem que seus de dentro

tenham perdido a intimidade:

que ela só, entre todas as cidades,

pode o aconchego de mulher,

pode o macio existir do mel,

que outrora guardava nos pátios

e hoje é de todo antigo bairro. (EPD, 384-385)

Sevilha não é apenas a "mais", tornando-se "única", pelo menos no universo do poeta. Embora tenha crescido, a cidade manteve seu centro antigo, sua feição anterior.

Além disso, Cabral também investe na comparação entre cidades e regiões, mostrando-se sensível à diversidade que compõe o território espanhol e seus conflitos. Se antes houve contraponto entre Castela e Catalunha, dessa vez diferencia a Andaluzia dessas duas regiões, que se julgam superiores:

O castelhano e o catalão

têm pobreza e riqueza tristes.

Assim desprezam a Andaluzia:

vêm-na africana ou sacrílega.

("Sevilha e a Espanha", Sevilha andando, EPD, 361) 
Catalunha e sua capital, Barcelona, de pretensões européias de além Pirineus, não reconhecem a vitalidade andaluza e sevilhana:

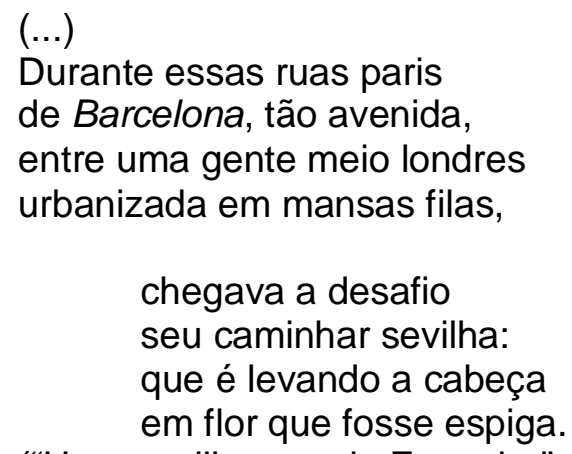

(“Uma sevilhana pela Espanha”, Serial, SA, 314)

(...)

Barcelona? Dançar é em vão,

não aplaudem, sentam nas mãos.

Coitados, são de uma outra gente.

Não são? Mas querem que se pense.

("A entrevistada disse, na entrevista:", Agrestes, EPD, 236)

A Catalunha, tira a tristeza

de querer ser muito mais França,

que não a interessa, senão,

enquanto Espanha, dá-Ihe entranhas.

("Sevilha e a Espanha", Sevilha andando, EPD, 361)

Madri, apesar de ostentar a severidade castelhana e a posição de capital, é suscetível à ação sevilhana sobre sua austera atmosfera:

(...) Dentro da vida de Madrid, onde Castela, monja e bispa, alguma vez deixa-se rir, deixa-se ser Andaluzia,

logo se descobria

seu ter-se, de Sevilha:

como, se o riso é claro,

há mais riso em quem ria.

Através túneis de museus, museus-mosteiros que amortiçam a luz já velha, castelhana, sobre obras mortas de fadiga, tudo ela convertia no museu de Sevilha: museu entre jardins 
e caules de água viva.

(“Uma sevilhana pela Espanha”, Serial, SA, 314-315)

Porém o contraste maior deu-se justamente entre duas cidades andaluzas, Sevilha e Córdoba, como verificamos em "A sevilhana que é de Córdoba" (Sevilha andando):

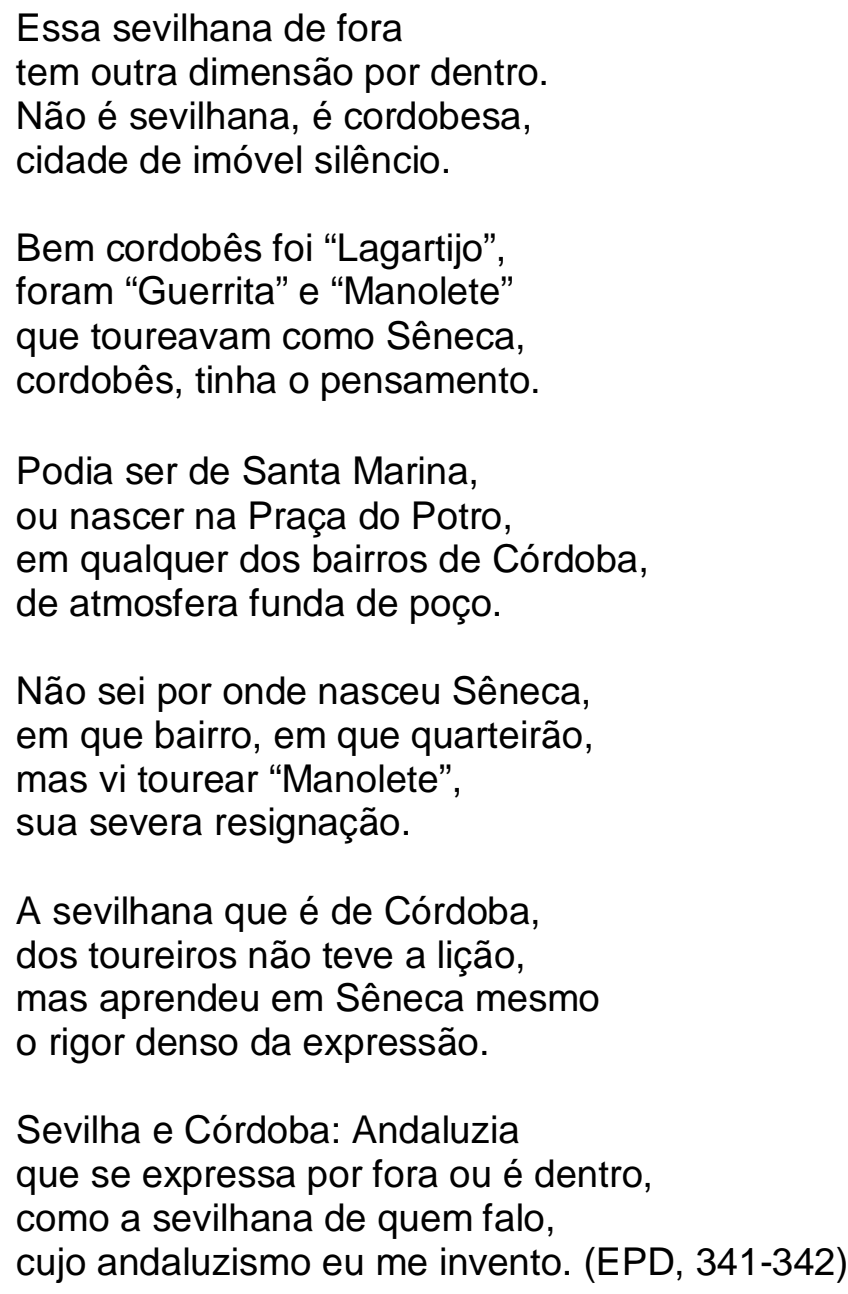

O mencionado Romero Murube apresentara em termos próximos as diferenças entre Sevilha e Córdoba:

(...) desde el punto de vista especulativo e intrascendente de las divagaciones literarias, que para ser buen amante de Sevilha es muy conveniente la sabia lección que Córdoba nos ortoga en muchas cosas: al guirigay continuado, una cura de silencio; al preciosismo narcisista, la robusta y escueta arquitectura de lo firme. 
Quizás sin que sepamos justificarlo, vemos a Córdoba como problema, y a Sevilla como aventura. Córdoba es una ciudad con raíces; Sevilla es una ciudad de alas y sonrisas. Allí nace un amplio silencio, fecundo y expectante; aquí bulle una musiquilla, un rumor perenne, que en su placentera continuidad llega a veces a excluir la posibilidad de un más profundo o exaltado acorde. (...)

(...) Dijimos en otros escritos cómo la sabiduría halla en Séneca la más alta expresión cordobesa. $(. . .)^{348}$

O ensaísta, como Cabral, associa o toureiro Manolete a sua cidade natal, Córdoba:

El cetro de la gloria taurina andaluza reposa con plena majestad entre las sedas y cenizas del gran Manuel Rodríguez. Bien: pues creemos que el toreo de "Manolete" era limitado y excesivamente arquitectónico. Como cordobés esencial, a su limitación le dio una profundidad inigualable, la de su valentía sin límites. Y a su arquitectura, esa frialdad irritante, desde el punto de vista artístico, de ejecutar los pases mirando al graderío, mientras el toro rozaba los hilos de la chaquetilla... "Manolete" creaba en las plazas silencios pavorosos: lo que él hacía, parecía que nadie más que él podía hacerlo.

(...) Las faenas del artista cordobés se ordenaban en pases previstos, escalonados, como las rimas cinceladas de un soneto gongorino... Arquitectura. ${ }^{349}$

A singular aproximação entre tauromaquia e literatura, no caso do também cordobês Góngora, remetia à recuperação promovida pela Geração de 27, que via no poeta do século XVII um grande exemplo de consciência e construção. ${ }^{350}$ Aliás, Cabral, na carta de 1947 a Bandeira em que relata suas leituras espanholas, repete entusiasmado por três vezes o nome de Góngora. Em carta seguinte, de 4 de setembro desse ano, conta que teve o privilégio de ver as últimas atuações de Manolete, comparando-o, não a Góngora, mas a Valéry, exponte moderno dos poetas conscientes: "(Faz hoje uma semana que um miúra matou Manolete, considerado o melhor toureiro que já aparecera até hoje. - Seja dito de passagem que era um camarada fabuloso: vi-o algumas vezes aqui em Barcelona e imaginei

\footnotetext{
${ }^{348}$ Memoriales y divagaciones In MURUBE, Joaquín Romero. Obra selecta. v. 2. Op.cit., p. 153-154.

${ }^{349}$ Idem, ibidem, p. 154-155.

${ }^{350}$ V. Capítulo 2.
} 
que era Paul Valéry toureando...). ${ }^{351}$ Em "Alguns toureiros", de Paisagens com figuras, recupera Manolete, "o mais deserto/ o toureiro mais agudo,/ mais mineral e desperto,". A paisagem a que se volta é o Nordeste: "o de figura de lenha,/ lenha seca de caatinga,". O seu modo de tourear, de parcimonia e controle de movimentos, continuava a promover vínculos literários, "lição de poesia" ao demonstrar aos poetas a não poetizar sua poesia, a não se servir de rompantes passionais.

Quanto a Córdoba, comparece em "A palo seco" de Quaderna em meio a imagens de precisão, depuração e construção, inclusive a arquitetura levantada por Romero Murube:

\author{
4.3. A palo seco existem \\ situações e objetos: \\ Graciliano Ramos, \\ desenho de arquiteto \\ as paredes caiadas, \\ a elegância dos pregos, \\ a cidade de Córdoba, \\ o arame dos insetos. (SA, 234-235)
}

Poderíamos nos perguntar por que Cabral não transferiu sua paisagem da árida Castela para a sóbria Córdoba, em princípio, mais afim com sua poética? Uma possível resposta estaria justamente na coletânea Quaderna, escrita entre 1956 e 1959, e que contém três poemas decisivos de sua temática espanhola: "Estudos para uma bailadora andaluza", "A palo seco" e "Sevilha", três facetas da Andaluzia "de fora" que se alternariam ou se articulariam na obra posterior. Devemos lembrar que nesse período entrou em contato com o Tempo espanhol de Murilo, que se abria a várias paisagens da Espanha. Talvez provocado em parte pelo livro do amigo, redirecionou sua Espanha para torná-la menos "amesquinhada" frente à totalidade muriliana. Em termos de paisagem, era capaz também de falar de outra Espanha, diferente da masculina, estéril e severa Castela, enveredando pela feminina, fértil e exposta Andaluzia. Dessa maneira, é sintomática a oferta de Quaderna a Murilo.

$\overline{351}$ SÜSSEKIND, Flora, org. Op. cit., p. 34. 
Mas Córdoba não fora esquecida. Retorna na última coletânea para ratificar a ambigüidade que Cabral sempre manteve entre suas paisagens, comparando-as e longe de estabelecer uma escolha definitiva. Os toureiros cordobeses dessa vez encontram seu paraleo literário no patrício Sêneca, raíz de uma linhagem espanhola de pensamento e escrita concisos e severos. Mesmo que a sevilhana não tenha visto Manolete como Cabral, aprendera em Sêneca o "rigor denso da expressão". Se Cabral relacionara Medinaceli com o autor anônimo do Poema de Mio Cid, no final de obra Córdoba reflete-se na obra de Sêneca, referência também para o poeta que poderia vir de muito antes.

\section{O gosto pelos extremos: a tauromaquia e o flamenco}

Desde seu primeiro contato com a Espanha, o flamenco e a corrida de touros impactaram Cabral, que passou a assistir a seus espetáculos: “(...) em Barcelona havia lugares onde havia quadros flamencos. Os catalães não gostam de flamenco, mas eu era um freqüentador inveterado desses lugares. ${ }^{352} \mathrm{Em}$ meio às últimas atuações do toureiro Manolete, idealizou uma antologia de "poetas de autores espanhóis modernos que tenham como tema as "corridas de touros". ${ }^{353}$ Embora o projeto não se tenha concretizado, alguns dos poemas que dedicou à corrida de touros e ao flamenco ao longo de sua obra poderiam figurar em qualquer antologia desses temas. Infelizmente, isso não costuma acontecer. A revista espanhola Litoral, em seu número 238 de 2004, dedicou ao flamenco um alentado volume intitulado $\mathrm{La}$ poesía del flamenco. Entre ensaios, fotos e reproduções de artes plásticas, figura "El flamenco en la lírica contemporánea", cujo único autor não espanhol é Rainer Maria Rilke. Para o leitor brasileiro ou familiarizado com a literatura brasileira, provoca no mínimo espanto a ausência de João Cabral de Melo Neto. Além de evidenciar o desconhecimento da obra cabralina relacionada à Espanha entre os atuais acadêmicos e escritores espanhóis, pode indicar dissonância dela frente aos modos tradicionais de tratar os temas daquele país, como bem observaram os não menos espanhóis Ángel Crespo e Pilar Gómez Bedate sobre "A palo seco":

${ }^{352}$ Entrevista de 1991 (ATHAYDE, Félix, org. Op. cit., p. 17). 
Contrasta fortemente a interpretação que este poeta brasileiro nos oferece do popular espanhol com a levada a cabo, sobretudo a partir dos anos vinte, pelos poetas espanhóis autores da chamada poesia neopopular, tão próxima ao tipismo para forasteiros, que terminou por degenerar em letra de canção aflamencada. É que o popular tem que ser visto como Cabral o viu: em profundidade, deixando de um lado o acidental, que costuma ser produto da interpretação alheia, e buscando o substancial. Ninguém poderá pensar que pecamos de nacionalismo se, relacionando este poema e muitas de nossas considerações anteriores com o fato de que Cabral tenha escrito a última e mais importante parte de sua obra a partir de seu profundo contato com a Espanha, afirmamos que sua estética soube fundir o ibérico, o iberoamericano de Pernambuco, com o hispânico e que, através deste poeta brasileiro, o espanhol tem sido um elemento importantíssimo da síntese de elementos cultos e populares que produziu uma das obras poéticas mais importantes do Brasil e, em geral, dos últimos decênios. ${ }^{354}$

Cabral diz na carta a Murilo de 1959 que reduzia flamenco e corrida de touros, componentes de uma "Espanha espiritual", a uma "lição de estética" desde os poemas "Alguns toureiros" e "Diálogo" de Paisagens com figuras. Nesse sentido, sobretudo os paradigmáticos "Estudos para uma bailadora andaluza" e "A palo seco", de Quaderna, foram amplamente comentados pela fortuna crítica do autor, em função de serem interpretantes da poética cabralina. ${ }^{355}$ No entanto, sem perder essa noção, as três artes, a corrida de touros, o cante e o baile flamencos, não só foram relacionadas entre si, como também ao substrato cultural espanhol - o andaluz, mais especificamente.

Em primeiro lugar, o poeta valoriza a economia de recursos, ao contrário de uma vertente de exuberância na lírica espanhola:

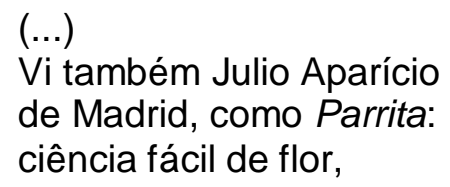

\footnotetext{
${ }^{353}$ Carta de 4 de setembro de 1947 a Manuel Bandeira (SÜSSEKIND, Flora, org. Op. cit., p. 33-34).

354 CRESPO, Angel e BEDATE, Pilar Gómez. Realidad y forma en la poesía de Cabral de Melo. Separata da Revisa de Cultura Brasileña. n. 8, Madri, março 1964, p. 67.

${ }^{355}$ Sobre "Estudos para uma bailadora andaluza", v. NUNES, Benedito. Op. cit, p. 114-116; LIMA, Luiz Costa. Op. Cit., p. 298-306; ESCOREL, Lauro. A pedra e o rio. Uma intrepretação de João Cabral de Melo Neto. Rio de Janeiro: ABL, 2001, p. 91-96; BARBOSA, João Alexandre. Op. cit., p. 170-176; SECHIN, Antonio Carlos. Op. cit., p. 134-139; e a respeito de "A palo seco", v. BARBOSA, João Alexandre. Op. cit., p. 159-163 e SECHIN, Antonio Carlos. Op. cit., p.152-155.
} 
espontânea, porém estrita.

("Alguns toureiros, SA, 131)

(...)

já não cabe duvidar:

deve ser telegrafia:

basta escutar a dicção

tão morse e tão desflorida,

linear, numa só corda,

em ponto e traço, concisa,

a dicção em preto e branco

de sua perna polida.

(“Estudos para uma bailadora andaluza", SA, 202)

I.1. Se diz a palo seco

o cante sem guitarra;

o cante sem; o cante;

o cante sem mais nada;

se diz a palo seco

a esse cante despido:

ao cante que se canta

sob o silêncio a pino.

("A palo seco", SA, 231)

Embora despojados, o baile e o cante flamencos representam verdadeiras lutas para atingir um ponto "extremo": "mesmo gosto dos extremos,/ de natureza faminta,// gosto de chegar ao fim"; "A palo seco é o cante/ de grito mais extremo:". Assemelham-se ao enfrentamento entre toureiro e touro, entre vida e morte, comparados em alguns poemas:

Mas o timbre desse canto

que acende na própria alma

o cantor da Andaluzia

procura-o no puro nada,

como à procura do nada

é a luta também vazia

entre o toureiro e o touro,

vazia, embora precisa,

em que se busca afiar

em terrível parceria

o fio agudo de facas

o fio frágil da vida.

("Diálogo", Paisagens com figuras, SA, 137) 


\begin{abstract}
A Espanha é uma coisa de tripa, do que mais abaixo do estômago; a Espanha está nessa cintura que o toureiro oferece ao touro,

e que é de donde o andaluz sabe fazer subir seu cantar tenso, a expressão, explosão, de tudo que se faz na beira do extremo.
\end{abstract} (“España en el corazón”, Agrestes, EPD, 237)

Porque é que todo sevilhano quer viver-se no aceiro da morte? Não é povo de jogadores que estime o deus baixo da sorte. Para o andaluz ser matador é o sonho que sonha de jovem, como ser bailaor, cantaor, ele tenta ser quando acorde, e que é também viver sobre um fio tenso, por em cima da morte, onde andar como equilibrista sobre um fio agudo de cobre. ("A imaginação perigosa", Sevilha andando, EPD, 384)

Portanto, as imagens de "Estudos para uma bailadora andaluza" e "A palo seco", por exemplo, articulam a tensão entre a manifestação do flamenco e o seu "vazio", sua "morte".

A força de "Estudos para uma bailadora andaluza" reside na dialética de movimento e estaticidade, explosão e contenção: fogo e cinza ("primeiro estudo"); cavaleira dominante e égua rebelada, variante feminina do toureiro e do touro ("segundo estudo"); atenção curvada do telegrafista e a telegrafia ("terceiro estudo"); camponês cavando a terra e árvore fincada na terra ("quarto estudo"); e as duas estátuas, do começo e do final da dança, mas acesas, desafiantes ("quinto estudo").

Quanto a "A palo seco", o grande embate dá-se com o silêncio. Desproporcional, pois o cante encontra-se "sem tempero ou ajuda", "despido e pouco", enquanto o silêncio, concretizado em metal, pele, líquido, ora pesado, ora levíssimo, e tela, é difícil de ser rompido. O silêncio inclusive pode "matar" o cante: esmagá-lo e afogá-lo, se indefeso, ou apodrecê-lo, se tem frestas.

Nas obras posteriores, em lugar de apenas descrever ou definir o baile e cante flamencos, Cabral voltou-se aos seus principais nomes, aos quais provavelmente assistiu ao vivo em suas estadas espanholas: "De Bernarda a 
Fernanda de Utrera" ( $A$ educação pela pedra) ${ }^{356}$; "A Antonio Mairena, cantador de flamenco" (Agrestes) ${ }^{357}$; "Manolo Caracol”358, "Carmem Amaya, de Triana"359 e "Niña de los peines" ${ }^{\prime 360}$ (Sevilha andando). Em alguns desses poemas, expõe o que se esconde por trás do cante, a dor que dilacera o cantor a partir das imagens da navalha e do punhal:

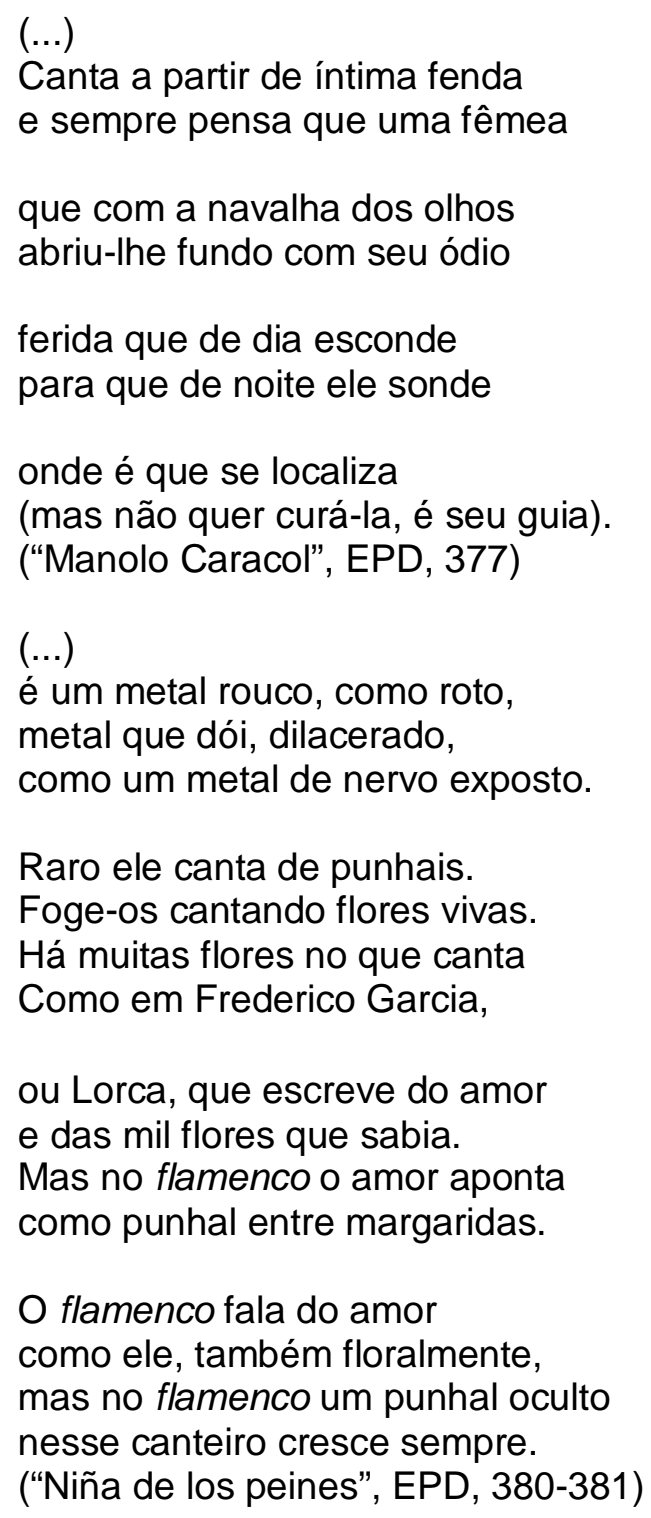

Talvez esses poemas sejam mais uma tentativa de mostrar uma Espanha menos "amesquinhada", que não fosse apenas uma "lição de estética", frente à

\footnotetext{
${ }^{356}$ Fernanda Jiménez Peña. Utrera, 1927. V. La poesía del flamenco, p. 250.

${ }^{357}$ Antonio Cruz García. Mairena del Alcor, Sevilha, 1909-1983. V. Idem, p. 210-211.

358 Manuel Ortega Juárez. Sevilha, 1909-1973. V. Idem, p. 242.

${ }^{359}$ Barcelona, 1913-1963. V. Idem, p. 246-247.

${ }^{360}$ Pastora Pavón Cruz. Sevilha, 1890-1968. V. Idem, p. 206-208.
} 
Espanha muriliana, aproximando-se, de certa maneira, da lírica espanhola sobre o flamenco. Basta comprovar o início dos poemas dedicados a Manolo Caracol e a Niña de los peines, respectivamente de Daniel Pineda Novo e Pablo García Baena, que emulam a dor do cante:
Tu grito fue de angustia y puñalada como um tremendo jay! de profecía y tu voz afilá fue la armonía al relente de turbia madrugada... ${ }^{361}$
Giralda de las voces... Padecía por su garganta un ave prisonera. Era la pena de la petenera y era un vuelo de llanto y agonía. ${ }^{362}$

Cabral investe tanto no universo interior do flamenco que assume a voz da bailadora Carmen Amaya, distanciando-se do espectador dos "Estudos para uma bailadora andaluza". Ela conta que tomou lições para sua dança com a tourada:

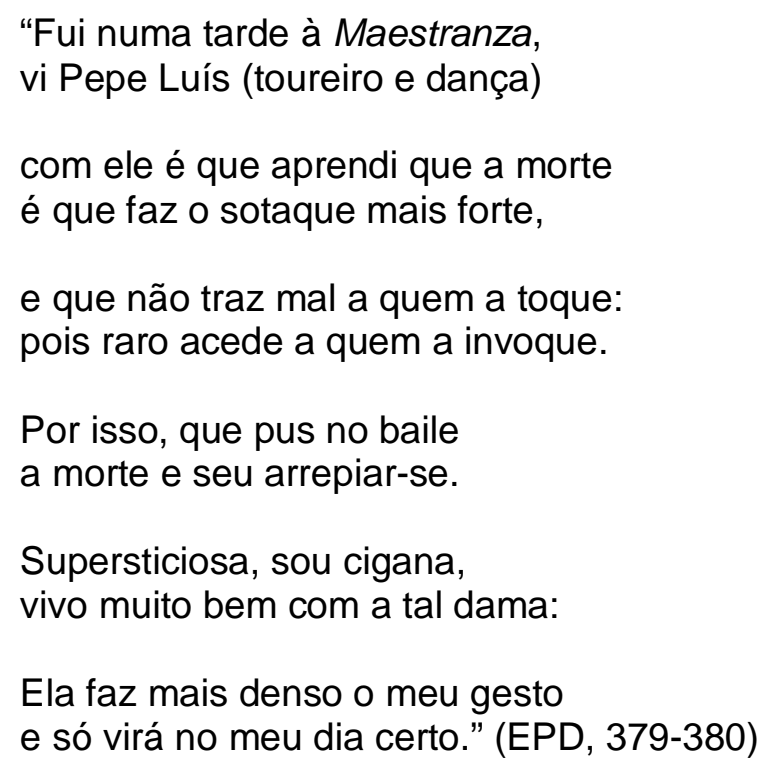

Pode ser que no poema de Quaderna já pensasse em Carmen Amaya, na "flora" "a que seus braços dão vida,/ densa floresta de gestos/ a que dão vida e agonia." O depoimento que Vicente Marrer realizou sobre a bailadora corrobora a fala imaginária de Cabral: "Gitanilla desgarbada, flaca, menuda, casi encorpórea,

${ }^{361}$ Idem, p. 244. 
con cara de ídolo trágico y remoto, pómulos asiáticos, de ojos largos cargados de presagios, brazos retorcidos, nerviosa, desgreñada como un bicho malo, mimbreña y violenta..." ${ }^{363}$ Cabral, no momento final de sua obra, pôde construir suas histórias com os mitos do flamenco e das corridas de touro, e não apenas valer-se de um símile para sua poética.

\section{A Sevilha espiritual}

Nas últimas obras escritas durante a década de 80 - Agrestes (1981-1985), Crime na calle Relator (1985-1987) e Sevilha andando (1987-1989), - ao lado das "idéias fixas" espanholas, Cabral aproximou-se em mais de um poema da religiosidade do país, ou melhor dizendo, de Sevilha. Vinte anos atrás, confessara a Murilo a sua incapacidade em abarcar uma Espanha "espiritual". Longe de uma conversão, esses poemas indicam, a partir de situações ou narrativas, uma abertura à instigante mescla que os andaluzes realizaram de sagrado e profano:

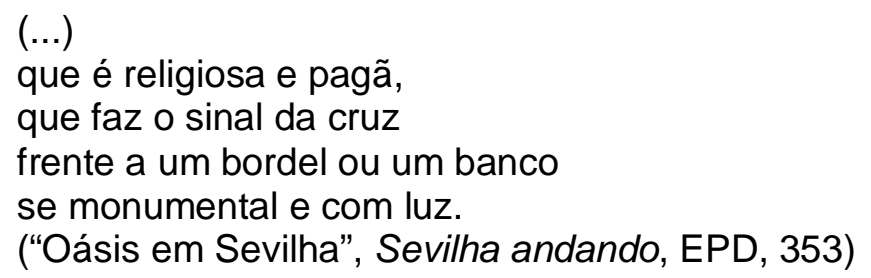

Recuperando os termos da carta de 1959, evitou a "Espanha negra" da Castela "monja e bispa" e defendeu a "Espanha branca" de Sevilha, esclarecendo não haver em suas crenças bruxaria ou magia, argumentos dos ataques do catolicismo oficial:

Não há tal embrujo em Sevilha.

Tudo é solar e sem mistério

e a superstição do sevilhano

é um manso animal doméstico,

com quem se convive, carrega

nos braços; mais bem é mascote,

\footnotetext{
362 Idem, p. 208.

363 Idem, p. 247.
} 


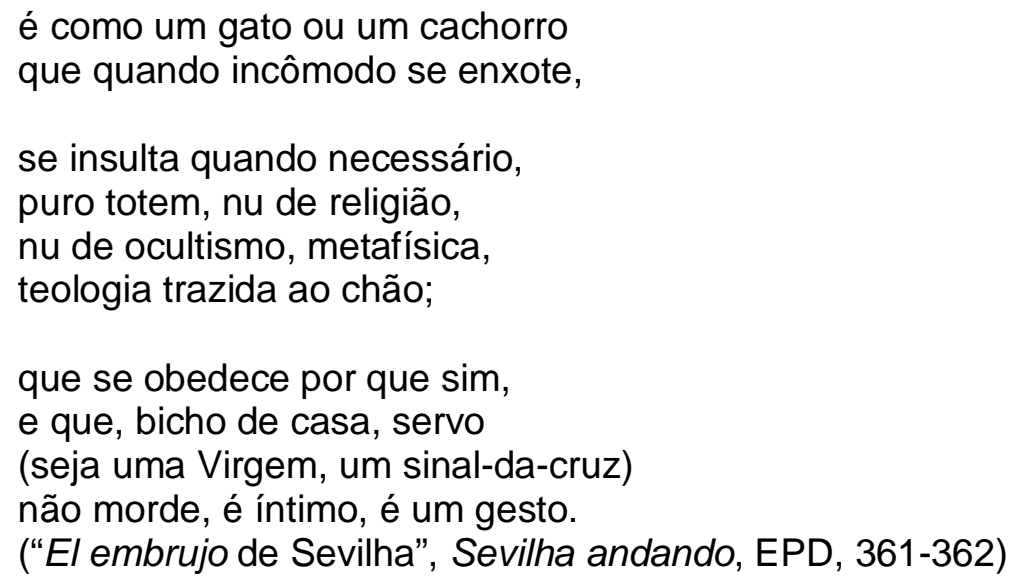

Três poemas de Agrestes põem em cena o catalocismo por meio de mulheres, como não poderia deixar de ser, sevilhanas. Não são beatas, mas trazem a faceta do inconformismo, da ingenuidade ou da emoção.

Para isso, o poeta faz com que surpreendamos uma "Conversa de Sevilhana" com seu parceiro na cama:

Se vamos todos para o inferno: e é fácil dizer quem vai antes: nus, lado a lado nesta cama, lá vamos, primeiro que Dante.

Eu sei bem quem vai para o inferno: primeiro, nós dois, nesses trajes que ninguém nunca abençoou, nós, desabençoados dos padres. (EPD, 227)

Saindo do âmbito da moral cristã, ela desafia, com sentido de desforra, figuras sociais merecedoras do inferno, até chegar à autoridade máxima:

Enfim, quem manda vai primeiro, vai de cabeça, vai direto: talvez precise de sargentos a ordem-unida que há no inferno. (EPD, 228)

Nos outros dois poemas de Agrestes, o eu lírico, escamoteado ao longo da obra cabralina, testemunha a reverência de sevilhanas diante de símbolos católicos. Em "Bancos \& Catedrais", conta da sevilhana que estando em Madri se benzia diante de um grande edifício que lembrasse uma igreja: 


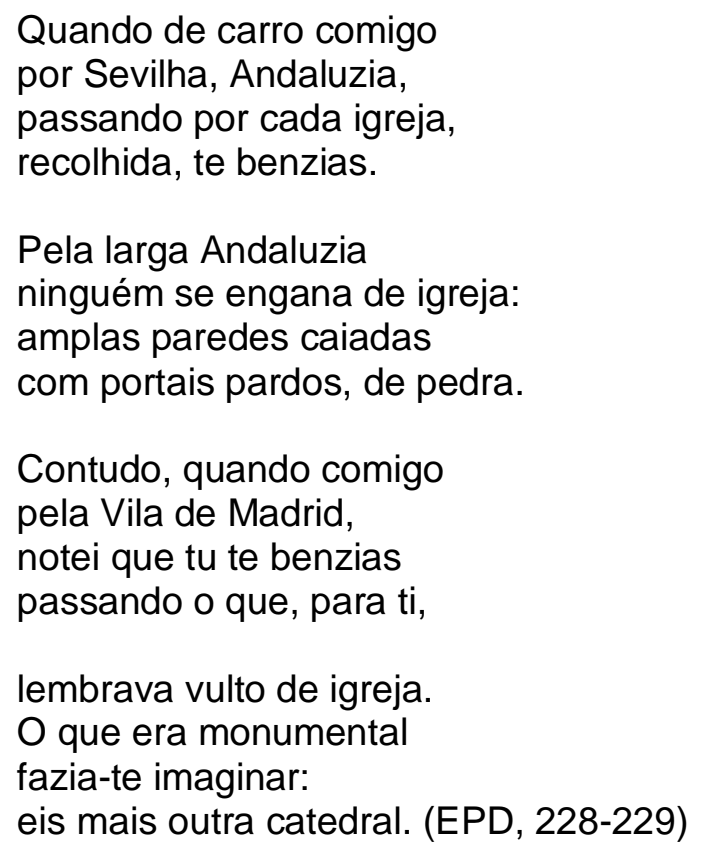

Mas a ilusão de ver igrejas onde se encontram bancos é ironicamente em parte confirmada, pois para o eu lírico o catolicismo e o poder econômico podem relacionar-se:

Sem querer, não te enganavas:
se não eram catedrais
eram matrizes de bancos,
o verbo de onde as filiais.
Só erravas pela metade
benzendo-te em frente a bancos;
quem sabe foram construídos
para lucrar desse engano? (EPD, 229)

No poema "O mito em carne viva", mais uma sevilhana, transposta à Castela, deixa-se comover com uma pintura da Crucificação, desabafando em sua variante andaluza do espanhol:

Em certo lugar de Castela, num dos mil museus que ela é, ouvi uma sevilhana, a quem pouco dizia a Fé, ante uma Crucificação comovida dizer a emoção mais nua e crua, corpo a corpo, imediata, ao pé, sem compunção fingida, 
sem perceber sequer

a névoa que a pintura

põe entre o que é e o que é:

Lo quié habrá sufr'io e’ta mujé! (EPD, 230)

Na segunda parte do poema, em lugar de desfazer o equívoco de uma visão como em "Bancos \& Catedrais", adere-se à veracidade da perspectiva desta sevilhana, sem pretensões religiosas ou eruditas, apenas humana; para ela não é mais uma representação pictórica de caráter sagrado, mas sim veículo que desperta emoções cujos símiles estão no mundo contemporâneo, o cinema e a televisão:

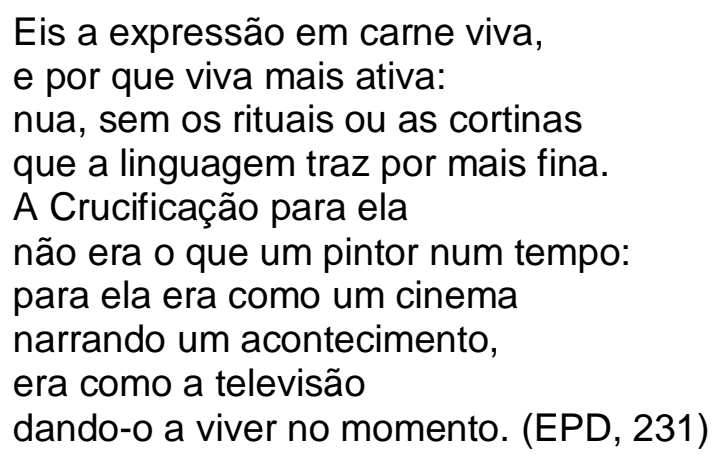

Contudo, nos museus da Andaluzia, como "O Museu de Belas Artes" (Sevilha andando), a arte sacra perderia sua "expressão em carne viva" por causa de seu luminoso entorno:

Este é o museu menos museu. No Convento de las Mercedes, palácio de tijolos frescos nada há de Convento nele.

Há jardins internos e fontes surtindo águas vivas em fios e a enorme luz que se abre invade tristes Cristos, sombrios bispos,

pendurados pelas paredes, mornos filhos da Renascença que a custo dão-se à dor e ao sério naquela invasão de sol sem crença. (EPD, 366) 
A Semana Santa, uma das maiores manifestações do catolicismo espanhol, que se mostra não apenas como devoção, mas também como espetáculo, comparece na produção final cabralina narrada do ponto de vista das populações marginalizadas, os ciganos, ou do povo das ruas. Em "Numa sexta-feira Santa", de Crime na calle Relator, conta-se a experiência de alguém não identificado provavelmente reminiscência do diplomata Cabral -, cujas impressões não interessam em meio às ações de ciganos com nomes próprios:

\author{
(...) \\ Preferiu passá-la em Utrera \\ que a faz em mais pobre maneira, \\ mas onde queria assistir \\ o Cristo Cigano que ia ir \\ reentrar na Matriz de Utrera \\ nos braços das saetas da Pepa. \\ Pepa, grande por bulerías, \\ cantando saetas estrearia, (EPD, 294)
}

A confluência de culturas revela-se tanto na denominação "Cristo Cigano", quanto na ocorrência das saetas, copla flamenca cantada na procissão da Semana Santa. Além das saetas, permitidas pela Igreja, mencionam-se outros tipos de flamenco, as bulerías, o cante e baile flamencos festivos, e as siguiriyas, o cante flamenco de música e temas tristes, como a morte e os sofrimentos do homem. Como nem sempre essas distinções estão claras para a força expressiva do cigano, pode sofrer as retaliações do poder legal e religioso, irmanados durante a ditadura franquista:

Passa que cantar por saetas, cante que aceita a própria Igreja,

faz-se com o mesmo compasso

das siguiriyas, que os ciganos

carregam no pulso e na língua

para confusão da polícia.

Porém se algum guarda-civil tiver o ouvido mais sutil 


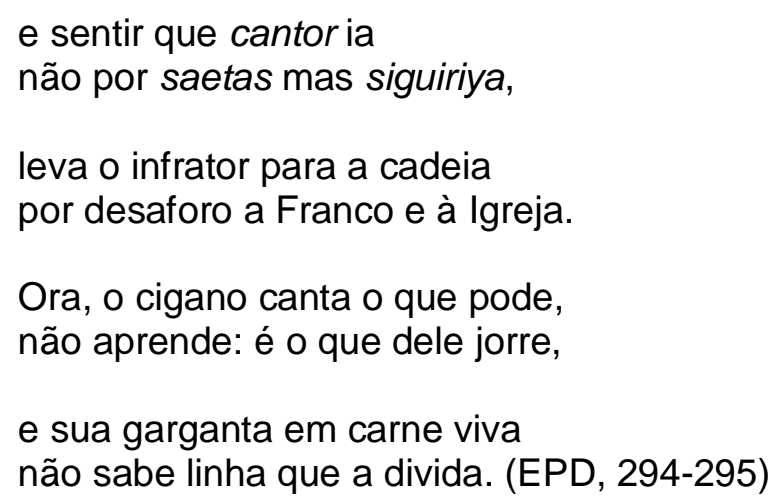

No entanto, Pepa canta a volta do Cristo por siguiriyas e não por saetas, "sacrílega infração" percebida por um guarda-civil "competente em flamenco" que apenas quer aparentar o cumprimento da ordem:

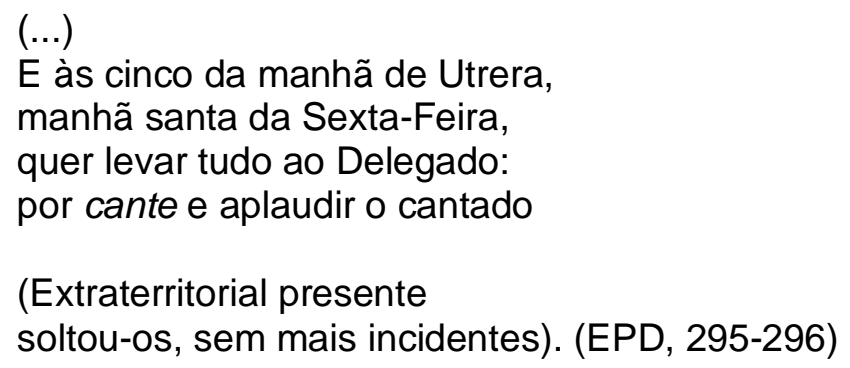

Por fim, a testemunha ocular presencia uma manifestação do genuíno flamenco, em plena Sexta Feira Santa, na intimidade da "casa da Cortés":

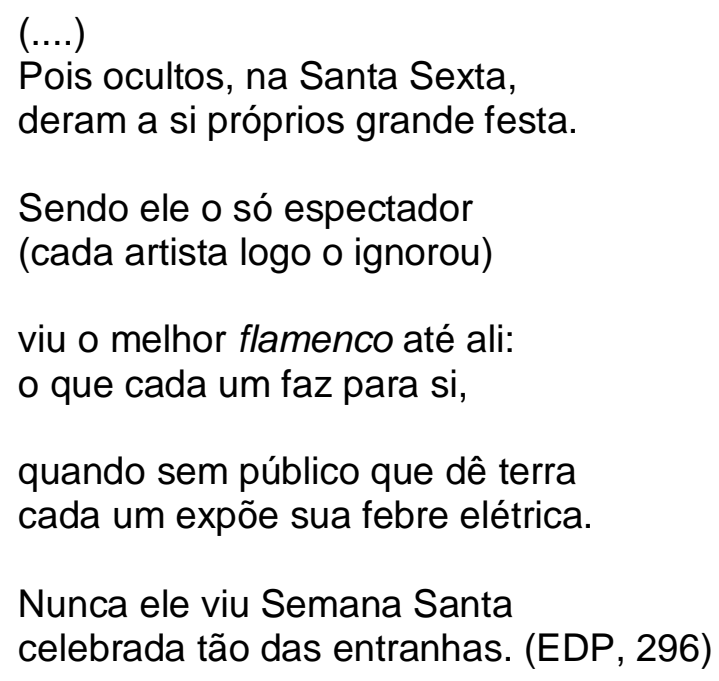

De Utrera a Sevilha, o poeta reveste-se de cronista para seguir as procissões da "Semana Santa" (Sevilha andando). As imagens sagradas são redimensionadas 
a uma condição humana e popular, como o Cristo "já cinqüentão", inclusive pelo homem que o acompanha do bar, soltando seu comentário sem cerimônia como a sevilhana diante da Crucificação:

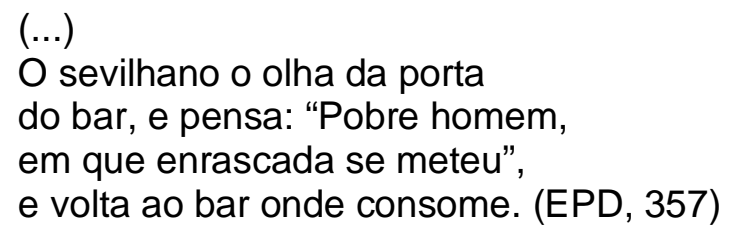

Mas as grandes estrelas são as Virgens das diversas Confrarias, recebidas quase sensualmente como mulheres:

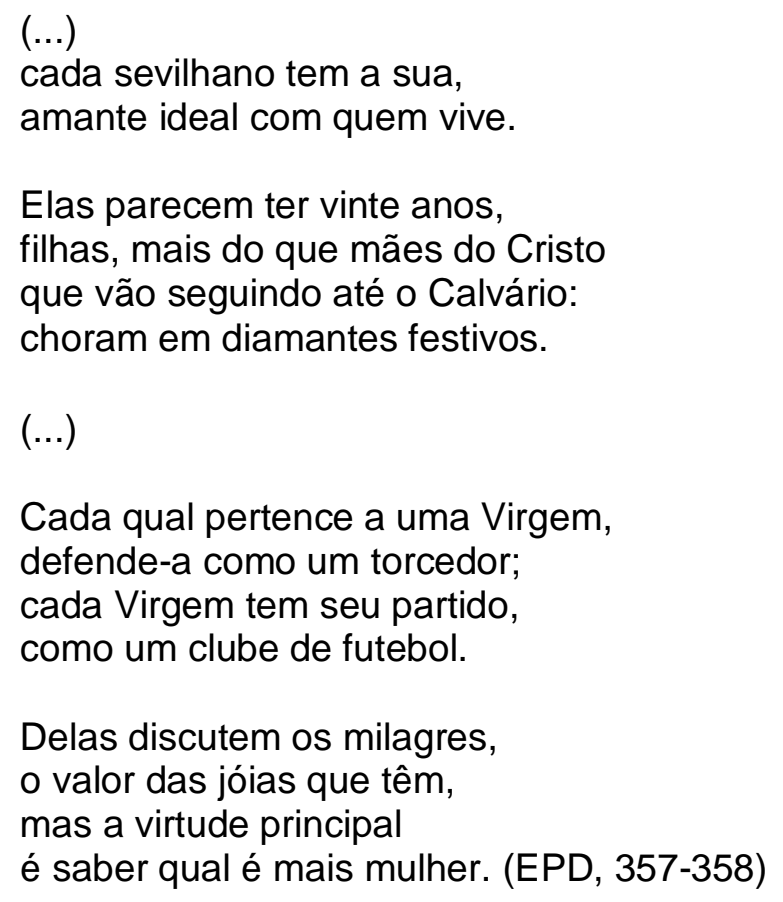

Não só das sevilhanas, dos ciganos e do povo das ruas compõe-se o quadro religioso apresentado por Cabral. Entre os poemas de Sevilha andando, atingiu os padres em "O asilo dos velhos sacerdotes"; um longo período intercalado por orações adjetivas ironiza as atividades comuns da carreira de um padre, além de denunciar a condenação do flamenco e a prática da intriga:

Os padres velhos de Sevilha, que pastorearam toda a vida 
que tanto sofreram dos hálitos beatos nos confessionários,

que pastorearam, literalmente, gado, galinhas, até gente,

que mastigaram o macarrão

do seu latim de igreja, em vão,

que puxaram as ladainhas

para cobrir as bulerías,

e ameaçavam com o inferno

quem se revelasse flamenco,

um inferno de labaredas

e música rança de igreja,

que só sabiam do silêncio

da fala baixa de intriguentos, (EPD, 367)

Rompe-se a expectativa de um triste fim condizente com tais condutas, sugerido desde a palavra asilo do título, pois os padres terminam em uma acolhedora Sevilha, mas não menos patéticos:

\author{
têm boa aposentadoria: \\ vêm dos povoados a Sevilha, \\ viver em paz a arquitetura \\ desse palácio de paz muda, \\ de muros frescos de tijolo, \\ onde num pátio deleitoso, \\ mordem com dentes que lá vão \\ o silêncio, final sermão. (EPD, 367-368)
}

Identificamos dois modelos discursivos em relação às imagens da Espanha no decorrer da obra cabralina: em um primeiro momento, de Paisagens com figuras a $A$ educação pela pedra, descreveram paisagens, artes e condutas, como modelos estéticos e até mesmo éticos; nas três últimas obras publicadas, narrou-se sobre uma Andaluzia e uma Sevilha que não foram vistas nem pelo olhar do exotismo do estrangeiro, nem pelo olhar preconceituoso das demais regiões espanholas, da Igreja e do Estado, mas sim por um poeta cronista que soube expressar as 
contradições dessa cultura. Por meio de um determinado lugar, conseguiu chegar a uma "Espanha total". 


\section{CAPÍTULO 6: Os tempos da Espanha de Murilo}

“(...) tema aliás de toda a literatura contemporânea, em vários escritores, inclusive em Machado de Assis, especialmente no capítulo sete de Brás Cubas, o delírio, é o problema do tempo... Não em vão escrevi Tempo e eternidade, Tempo espanhol. Enfim, eu sou hanté pelo problema do tempo."364 O depoimento de Murilo é revelador não apenas para determinadas coletâneas, mas para o conjunto de sua obra, na medida em que buscou elaborar uma concepção do tempo, da História. E quando se refere ao tempo, quase sempre evoca seu par complementar, o espaço. Por isso, além de Tempo espanhol, escreveu o livro de viagens Espaço espanhol. No estilo dos aforismas de $O$ discípulo de Emaús, poderíamos afirmar que, para Murilo, o tempo é poesia e o espaço é prosa, ou melhor, prosaico. No final do texto dedicado à cidade espanhola de Genora, o poeta volta-se às duas noções que delimitam a experiência humana:

Quem me restituirá na sua complexidade estimulante o corpo terrestre de Gerona? Quando? Giramos a vida em torno deste advérbio de tempo. "Quando?", Gerona, é geral interrogação de todos os dias. Seremos nós homens o próprio tempo resumido em carne e osso? Gerona, a epopéia da criação do mundo, o conhecimento acelerado da matéria, superando agora as fórmulas de Einstein, desenrolam-se no tempo, diante dos nossos olhos iniciados; não terminaram; mas todos queremos nos libertar do tempo qualitativo e quantitativo. Haverá alguma coisa mais obsedante do que o tempo? Em Gerona vi mais uma vez o tempo, toquei-o; esse tempo que às vezes tomamos do espaço. O espaço! Queremos agora libertarnos também do espaço. Oculto na tua cápsula, cosmonauta, distingues ou não as plataformas de Gerona, o espaço de Gerona, o homem de Gerona? (PCP, 11641165)

Bem ao gosto do Modernismo da década de 20, ele partiu de um presente circunstancial, do Rio de Janeiro e seu subúrbio, fazendo uma excursão pelo passado do país em chave satírica, na História do Brasil. Mas não permaneceu nessa posição, estimulado pela abertura a novas dimensões, graças ao surrealismo

${ }^{364}$ ARAÚJO, Laís Correa de. Op. cit., p. 357. 
e à amizade decisiva com Ismael Nery. O pintor formulou o sistema essencialista como preparação ou introdução ao catolicismo, fundamentado na "abstração do tempo e do espaço, na seleção e cultivo dos elementos essenciais à existência, na redução do tempo à unidade, na evolução sobre si mesmo para descoberta do próprio essencial, na representação das noções permanentes que darão à arte a universalidade., ${ }^{365}$ O princípio da universalidade, almejado por Murilo desde o início de sua produção poética, e que remava contra a maré nacionalista do Modernismo, possibilitou-Ihe que cada vez mais absorvesse as propostas do amigo. A última parte da obra de estréia, Poemas, significativamente intitulada "Poemas sem tempo", desenvolve a "sucessão, analogia e interpenetração de formas" ${ }^{366}$ entre membros da família, primeira tentativa de figurar uma permanência para além das contingências cronológicas.

Tais percepções, depois da firme adesão ao catolicismo, configuram-se na coletânea Tempo e eternidade, escrita em 1934, na qual vários poemas apostam no doutrinário para enfrentar a convulsão política da década de 30 , no Brasil e no exterior, que desembocaria na Segunda Guerra Mundial. A "Filiação" do eu lírico à eternidade, em detrimento do tempo e do espaço, afirma-se:

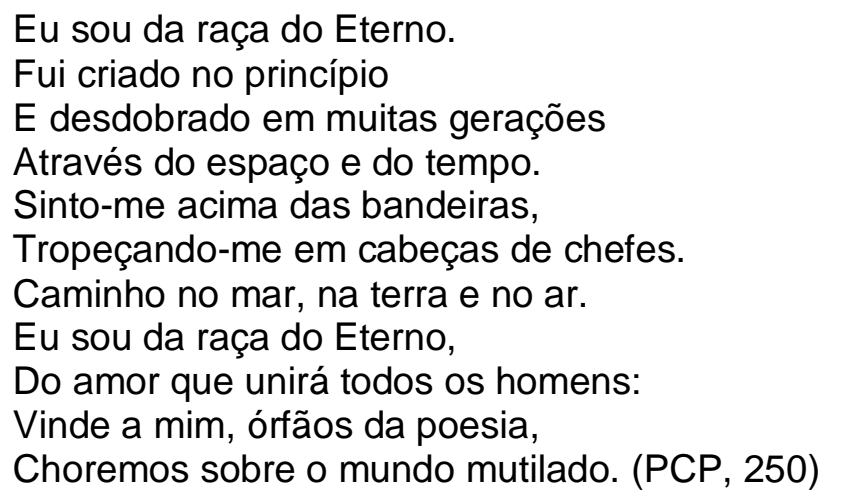

Muitos poemas com as formas verbais do futuro apontam o fim dos tempos e o encontro de Cristo na eternidade. Às vésperas do conflito mundial, situado pela pertubadora imagem das crianças que dormem com fuzis, Murilo lança sua "História" (As metamorfoses, Livro Primeiro, 1938):

${ }^{365}$ MENDES, Murilo. Recordações de Ismael Nery. Op. cit., p. 65. 
Os mares se contraem.

As nuvens esticam as asas.

O espaço abre-se em sedes e clamores.

Dos que nasceram há mil anos

E dos que ainda vão nascer.

Há uma convergência de presságios

Nos jardins cobertos de rosas migradoras

$E$ nos berços onde dormem crianças com fuzis.

O espírito poderoso que fundirá os tempos

Espera, impaciente, nos átrios celestes. (PCP, 330)

A História com orientação providencialista do divino passa a nortear a poesia muriliana escrita sob o impacto da Segunda Guerra Mundial, cujas imagens muitas vezes foram inspiradas no Apocalipse: o Livro Segundo de As metamorfoses (1941), intitulado provocativamente como "O Véu do tempo", a encobrir a redenção da eternidade; Mundo enigma (1942); e principalmente, Poesia liberdade (1943-1945). $\mathrm{Na}$ última coletânea comparece o único poema de toda a obra de Murilo em que o tempo é tematizado nas mais diversas ações de um presente contínuo, anunciando o poder que assumiria na poesia posterior:

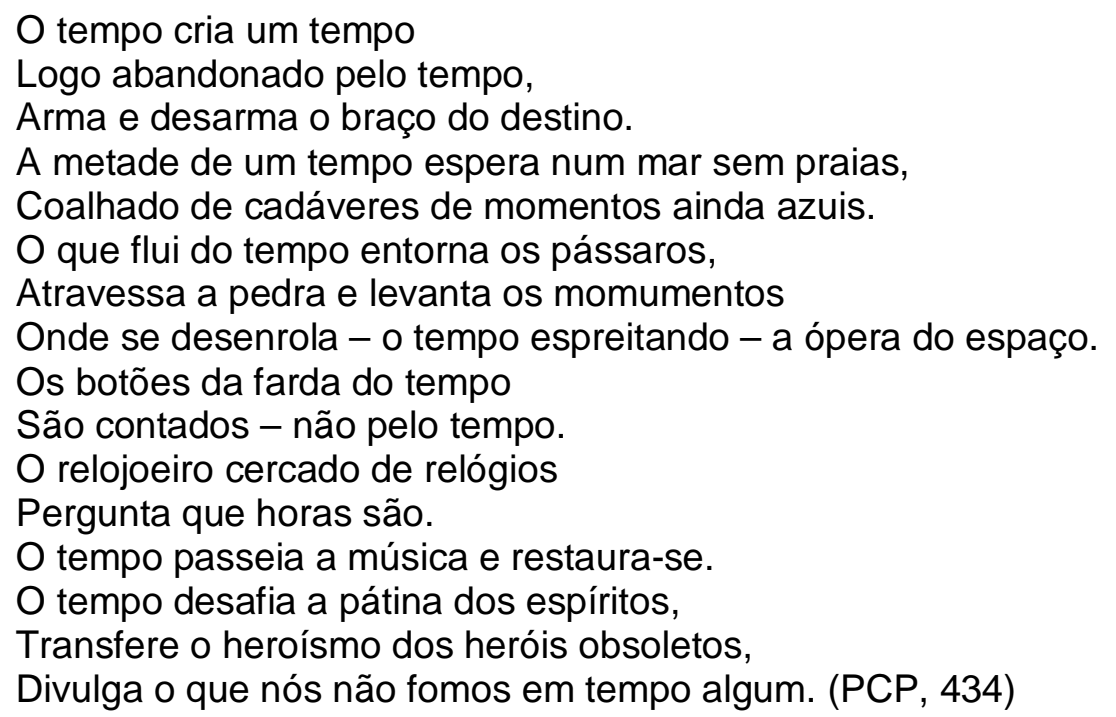

Tempo e espaço não são meramente desprezados, mas se constituem a partir do concreto, do signo perene da pedra: "Atravessa a pedra e levanta os monumentos/ Onde se desenrola - o tempo espreitando - a ópera do espaço." As imagens descontínuas tentam materializar a abstrata noção de tempo, assim como

${ }^{366}$ Idem, p. 30. 
uma série dos contemporâneos aforismas de O discípulo de Emaús (1945). No de número 251, por exemplo, em três concisas frases formulou a trajetória da humanidade sob a ótica do cristianismo: "A criação é a tese. O pecado original, fundador do tempo e da história, é a antítese. O juízo final é a síntese." Em vários, o par tempo-espaço não se desvincula:

33: O reino de Deus está em nós. Não está sujeito ao tempo nem ao espaço.

54: O tempo e o espaço são duas categorias anacrônicas que o homem deverá abstrair se quiser conquistar a poesia da vida.

253: A ciência é o estudo do tempo e do espaço. A poesia é a aventura no tempo e no espaço. A religião é a ciência fora do tempo e do espaço.

541: O tempo é uma dimensão do espírito, o espaço é uma dimensão do corpo.

623: O espaço e o tempo estão catalogados e previstos.

715: Os princípios mecânicos só podem funcionar no tempo e no espaço. O espírito livre os supera. [grifos nossos]

Os aforismas citados associam tempo-espaço como categorias subjugadas à eternidade divina, única aspiração válida. O binômio tempo-espaço tornou-se crucial no conjunto da poesia muriliana formado por Contemplação de Ouro Preto, Siciliana e Tempo espanhol, obras circunscritas por um determinado espaço - cidade, ilha e país - e recuadas no tempo. O que a fortuna crítica de Murilo geralmente reconhece como um novo período da obra que se volta a uma realidade empírica corresponde a um mergulho profundo na tradição, na História, mas sem abandonar os princípios católicos.

A primeira lição de História deu-se na Minas Gerais natal, em Ouro Preto, a Vila Rica colonial redescoberta pela primeira geração modernista. Ao lado do sogro, o historiador português Jaime Cortesão, e do diretor do Serviço do Patrimônio Histórico e Artístico Nacional (SPHAN), Rodrigo Melo de Franco Andrade, visitou no final dos anos 40 a antiga capital mineira, sensibilizando-se com seus monumentos e suas histórias. A paisagem montanhosa e irregular que configurou todo um traçado urbano imprime sua permanência no poema de abertura da coletânea de 1954, "Motivos de Ouro Preto": 
(...)

E contra a dispersão das ossadas no tempo,

Que o amor à forma e a Promessa rejeitam,

Da pedra o testemunho antigo se levanta,

Poder do Itacolomi - e o da Pedra perene. (PCP, 458)

Contudo, na Europa, Murilo deparou-se com muitos mais séculos de História, que convivem em um mesmo lugar como registros de diferentes épocas. Entre diversos locais para uma primeira eleição, aportou à ilha da Sicília, de história anterior a Cristo, que deixou ruínas integradas à natureza pela força da pedra. ${ }^{367}$ Depois das igrejas de Ouro Preto, circulou entre os templos e túmulos da ilha para ratificar a participação de tudo e de todos na eternidade:

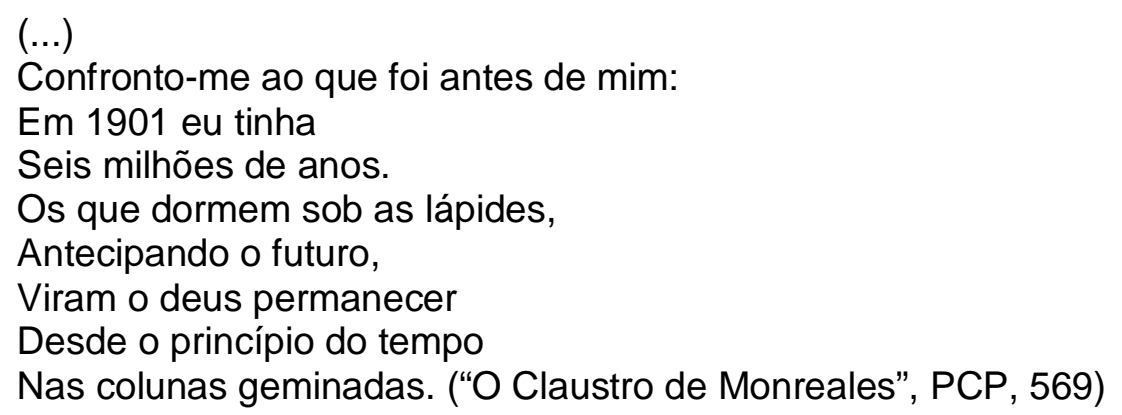

Finalmente, ampliou os horizontes para a Espanha em Tempo espanhol, última obra poética de uma incessante produção começada na metade dos anos 20 , antes de enveredar pela prosa e pelas últimas experimentações de Convergência. Ao contrário de uma tradição crítica proposta por Haroldo de Campos que vê, sobretudo nesse livro, o ápice de um caminho de depuração e construção formais, podemos apresentá-lo como uma interpretação decisiva da temática do tempo. Assim, Murilo escolheu uma das mais intensas nações católicas da História, a Espanha de "lição de ética exemplar, da qual um dos temas fundamentais é a justaposição do homem interior ao homem exterior, inserido na história mas consciente do valor da sua alma individual, (...)" (PCP, 1471).

A tensão "tempo e eternidade" integrou-se de forma harmoniosa em Tempo espanhol. Diferentemente da linha progressista e materialista da História do Brasil da década de 30 , percorre-se a história dos primeiros povos da Antigüidade à

\footnotetext{
${ }^{367}$ Ver a análise de Davi Arrigucci Jr. do poema "As ruínas de Selinunte", no ensaio "Arquitetura da memória" (O cacto e as ruínas: a poesia entre outras artes. São Paulo: Duas Cidades; Ed. 34, 2000).
} 
ditadura franquista segundo uma interpretação figural. Estudado por Erich Auerbach, em relação à Idade Média cristã, a interpretação figural é o modo patrístico e escolástico de definir e orientar cristãmente o sentido do tempo na experiência histórica. A figura é, basicamente, a relação, especular e substancial, estabelecida entre homens, coisas e eventos do Antigo e do Novo Testamentos; "algo real e histórico que anuncia alguma outra coisa que também é real e histórica. A revelação entre os dois eventos é revelado por um acordo ou similiaridade."368 Dessa maneira, as pessoas e fatos do Velho Testamento são prefigurações do Novo Testamento, como Moisés é uma prefiguração e Cristo seu preenchimento. Os acontecimentos não apenas se remetem um ao outro, mas também à promessa do fim dos tempos e do verdadeiro reino de Deus, que, de acorodo com a doutrina cristã, sempre existiu e sempre existirá.

A construção temporal do livro de 1959 corresponde a um deslocamento geográfico, figurando determinados espaços como palcos de determinados tempos. Ratifica a íntima associação tempo-espaço também em Espaço espanhol, no qual não apenas descreve cidades, mas também constrói seus tempos. Em mais de uma passagem é evidente sua preocupação com a alteração de uma ordem antiga para dar lugar à modernidade do século $X^{369}$, quando, final da década de 60, a Espanha já abandonava seu caráter predominantemente rural. Nesse aspecto, concorda com João Cabral, citando o poema "Sevilha" de Quaderna ${ }^{370:}$ "Deduzimos portanto que Sevilha é feita à medida humana; esse texto implica uma censura ao gigantismo de

\footnotetext{
${ }^{368}$ AUERBACH, Erich. Figura. Trad. Duda Machado. São Paulo: Editora Ática, 1997, p. 27. Murilo Marcondes Moura, para a leitura de "Janela do caos" de Poesia liberdade, valeu-se da noção de figura desenvolvida por Auerbach ("História: figura da eternidade" In Murilo Mendes. A poesia como totalidade. Op. cit., p. 170-172).

369 "Ainda existirão espanhóis dentro dos arranha-céus?" (Madrid, PCP, 1126); “(...) O caráter da antiga Ávila 'mística e tradicional, honesta e dura', custará talvez a se adaptar aos hábitos dos últimos invasores: o técnico e o capitão de indústria" (Ávila, PCP, 1139); “(...) Depois regresso às margens do Pisuerga; debruço-me no parapeito; e, pisuergando, auguro para os homens a impossível mansedumbre que subsiste na água barrenta de um rio castelhano a exorcizar os poderes mecânicos do século." (Valladolid, PCP, 1148); “(...) O processo de modernização demorou um pouco mas já está se implantando aqui. Perto do Palácio de los Momos, de tão singular fantasia, com suas janelas em ajimez, instalaram um posto de gasolina; muitas lojas do centro se americanizaram. O fim do mundo virá por efeito de bombas americanas ou chinesas? De qualquer modo, não por bombas espanholas." (Zamora, PCP, 1152); "(...) Cada vez que volto aqui pergunto-me preocupado se esta gente conservará seu caráter específico mesmo depois de tantos anos de governo ditatorial, de americanização e de rápida industrialização. Naturalmente muitos hábitos estão-se modificando, assim será cada vez mais: de qualquer modo creio que os traços característicos da psique espanhola permanecerão apesar das fortes pressões internas e externas." (Salamanca, PCP, 1155); "(...) ponhome a congeminar o que será o futuro da terra palentina; por exemplo, se a forma desses campos, dado o avanço da urbanização espanhola, subsistirá no dia de amanhã; é mais provável que segundo a metáfora bíblica, seja logo mudada como um vestuário." (Palencia, PCP, 1157).

${ }^{370}$ V. Capítulo 5.
} 
tantas cidades modernas que perderam, quase, a relação com seu criador e protagonista, o homem." (PCP, 1176)

Tempo espanhol pode ser considerada uma das obras mais elaboradas e coesas de Murilo, mais que um mero conjunto de poemas ou um desfile históricoartístico. Por isso, ao longo da coletânea, identificamos núcleos espaço-temporais que seguiremos neste capítulo: as origens e a ldade Média; os séculos XVI e XVII, o chamado Siglo de Oro, na região de Castela; um intermezzo, entre o século XVIII e início do XX; a Andaluzia; e por último, a ditatura franquista e as vanguardas artísticas na Catalunha.

\section{O começo e o fim da Espanha}

Os 11 primeiros poemas de Tempo espanhol acompanham a formação e a Idade Média, regredindo até às montanhas catalãs de "Monteserrate", "Anteriores ao primeiro homem":

Eis o território disforme

Onde o espírito sincopado

Tenta escalar Deus e a pedra:

Espanha por se construir. (PCP, 578)

Espaço espanhol, por sua vez, abre-se com o texto sobre "Altamira" e suas pinturas rupestres, as quais para Murilo permanecerão inclusive no fim dos tempos no lugar de outras conquistas mais recentes e civilizadas do homem: "Coisa estranha: ao deixar esta cova tenho a sensação de haver penetrado nos arcanos do fim do tempo, em vez de retornar ao princípio. No fim do tempo, isto é, quando se acumularem as ruínas do que foi o homem e seu esforço de levantar o monumento da história; quando só restarem vestígios, não do seu 'idealismo', da sua 'arte', da sua 'ciência', mas da sua substituição mágica pelo animal das cavernas." (PCP, 1122). Segundo Murilo, esse animal pode ser um "longínquo pressentimento do rito taurino", assim como a "Cabeça de touro maiorquina", de Tempo espanhol. 
Montserrat e Altamira são "terra de Espanha, sim, mas não história de Espanha." (PCP, 1121). No entanto, prefiguram elementos da Espanha que virá. Tal processo ocorre de maneira plena logo no poema de abertura, "Numancia":

\author{
Prefigurando Guernica \\ $\mathrm{E}$ a resistência espanhola, \\ Uma coluna mantida \\ No espaço nulo de outrora. \\ Fica na paisagem térrea \\ A dura memória da fome, \\ Lição que Espanha recebe \\ No seu sangue, e que a consome. (PCP, 577)
}

Numância é o nome de uma população desaparecida a $7 \mathrm{~km}$ da atual cidade de Soria. No último bloco do texto a respeito da cidade em Espaço espanhol, Murilo extende a compreensão do conciso poema:

Descortino o horizonte de Numância, deserto, imensurável a olho nu. Observo a vegetação rasa onde um ou outro resto de coluna se salienta, algum marco a assinalar o episódio da grande resistência aos romanos; recuando nos séculos descubro a atualidade de Numância na sua gesta épica. Resistência; não deveria ser esta a palavra de ordem universal? Resistência à agressão, à lei do lobo ou da raposa, a qualquer violência, fardada ou não. (PCP, 1144)

Depois de 14 anos de lutas, um cerco em 133 a.C. venceu Numância pela fome. Os habitantes preferiram a morte a se entregar, chegando a incendiar a cidade para que não ficasse para os romanos. História convertida em mito, tanto que o adjetivo numantino entrou para a língua espanhola com o significado, "que resiste con tenacidad hasta el límite, a menudo en condiciones precarias".

Após a evocação que o título "Numancia" pode conotar, a palavra inicial do poema, o verbo prefigurando, inaugura a concepção histórica que norteia Tempo espanhol. Assim como Murilo aprendera a história dos judeus como uma figura do surgimento de Cristo, a resistência de Numância aos romanos é uma figura de outras resistências do século XX na Espanha: do bombardeio a Guernica em 1937, que se tornou símbolo das atrocidades da guerra no mundo contemporâneo, e da 
ditadura franquista, velada nesse começo e explícita nos últimos poemas. Acontecimentos similares pela imposição da carência e pela morte dos adversários. No último "setor" de Tempo espanhol, que analisaremos mais adiante, o poema "Guernica" pode ser visto como preenchimento da figura de "Numancia": "Aumentando a comarca da fome,", o episódio segue a lição recebida do episódio da Antigüidade. Mas o verbo final, consome, indica que o drama repercute ainda na atualidade. O que parecia o começo pode anunciar o fim.

\section{O núcleo de Espanha: Castela e o Siglo de Oro}

Os 20 poemas seguintes - a maior seqüência de Tempo espanhol adentram Castela e o denominado Siglo de Oro, que entre os séculos XVI e XVII correspondeu ao período de maior esplendor nas artes espanholas. Murilo explicitou a importância crucial desses espaço e tempo espanhóis: “(...) o ambiente da meseta castelhana remete-nos a uma época nuclear da Espanha: quando de novo se encarna historicamente o tema da vocação sagrada do homem, aperfeiçoando-se a disciplina dos sentidos, ampliando-se a visão das fronteiras da morte; quando a consciência das duas tarefas, a terrestre e a transcendente, se resume na pessoa de Santa Teresa, segundo alguns tão reveladora da substância espanhola quanto Cervantes." (PCP, 1144). Para a Antologia poética de 1964 que ele mesmo preparou, o maior número de poemas de Tempo espanhol advém desse período. ${ }^{371}$

Seguindo a tradição dos escritores da geração de $98^{372}$ - Murilo foi, naturalmente, leitor de Unamuno e Azorín, entre outros - revisita o tópico da Castela escassa e áspera:

\footnotetext{
Na estepe de Castela o homem mede a sede, Mede o sol, desdém e força.

$\mathrm{Na}$ estepe de Castela

O homem mede suas malandanças,

Caminha com a rudeza a tiracolo.

$\mathrm{Na}$ estepe de Castela

Campos desnudos, vento e argila,

Céu côncavo, cifrado,

Determinam o espaço substantivo,
}

\footnotetext{
371 "Santa Teresa de Jesus", "São João da Cruz", "Lida de Góngora”, "Tema de Calderón" e "Tempo de Quevedo" (Lisboa: Livraria Morais Editora, 1964).

${ }^{372}$ V. Capítulo 5.
} 
O estilo do silêncio

E o silêncio cria o homem de Castela. ("Homenagem a Cervantes", PCP, 587588)

As noções de concretude e depuração - associadas na imagem do "silêncio e solidão sólidos" de Toledo - , que caracterizam Tempo espanhol, encontram nessa parte sua formulação mais veemente.

Murilo, jamais circunscrito por um tempo determinado, estabelece paralelos entre o Siglo de Oro e o século XX, conjugando passado e modernidade. O início do poema "Ávila" aproxima o movimento do vôo sobre a cidade castelhana da experiência mística de Santa Teresa: "O avião abrindo curvas dá guinadas/ Como os movimentos da alma na escrita de Santa Teresa." (PCP, 584). Por outro lado, como repetiria em várias passagens de Espaço espanhol, o avanço do progresso pode interferir em toda uma tradição:

(...)

Castela interior que me demarcas,

Correspondes à outra Castela clássica,

Ameaçada Castela: aqui a indústria

Já inaugura sua máquina indiscreta. ("Homenagem a Cervantes", PCP, 588)

Desde que retire os homens da sua condição precária, o poeta não se opõe ao desenvolvimento. A resistência - uma das palavras-chave de Tempo espanholao tecnicismo da época atual virá da memória do patrimônio artístico da Espanha, no poema em questão, o maior símbolo dele:

Mas, se deve nutrir teus homens secos,

Que venha e permaneça a máquina indiscreta:

Frente ao excesso mecânico da técnica,

Frente a moinhos com radar, Dulcinéias de vidro, armaduras atômicas,

Responderá o equilíbrio de Cervantes. (PCP, "Homenagem a Cervantes", 588)

A transposição de El Quijote ao presente do poeta dá-se também com outro texto fundamental do Siglo de Oro, La vida es sueño, no poema "Tema de Calderón". Segismundo, ao ser retirado de sua "torre atômica", depara-se com o desconcertante cenário de um centro urbano: 
(...)

Caminho entre semáforos e máquinas.

São andaimes, passos arritmados, poeira,

As pequenas combinações da vida, suor,

A linguagem dos ácidos, nada álacre. (PCP, 597)

As dúvidas do Segismundo original ampliam-se e tornam-se os dilemas do intelectual contemporâneo:
(...)
Quem finalmente sou, esqueleto letrado,
Alienado eco? A injustiça não me cabe
A mim só: qualquer um a reclama e recebe.
Mas eu sonho a injustiça, ou a suporto?
Eu sonharei a vida, ou a vida me sonha?
Aprendi do meu sangue, ou da essência de Espanha?
Calderón, ainda no contexto atual do século
LA VIDA ES SUEÑO. (PCP, 597)

De todos os modos, na leitura do ensaio "Escila y Caribdis de la literatura española", de Dámaso Alonso ${ }^{373}$, Murilo destacara que o segredo do Siglo de Oro estava na síntese da tradição medieval espanhola e do Renascimento europeu: "Esta es la clave del momento culminante de España, del momento en que se concentran nuestras energías y nuestros valores; por eso ha de ser también la explicación de toda el alma española., ${ }^{374}$ Ernest Robert Curtius, em seu clássico Literatura Européia e Idade Média Latina, defende a importância do Siglo de Oro ao se valer da noção de "teatro do mundo", totalidade que seguramente fascinou Murilo: “(...) A literatura áurea espanhola conservou a substância do Ocidente cristão. Via na história um 'arquivo dos tempos' em que os povos de todas as épocas e lugares tinham consignadas suas recordações. Os reis e heróis, os mártires e camponeses são atores do grande teatro do mundo. Poderes sobrenaturais intervêm nos destinos. Tudo é dominado pelo encadeamento da graça e da sabedoria de Deus. ${ }^{375}$

Além de acompanhar em suas leituras o desenrolar do "teatro do mundo", recuperou o freqüentado tópico da brevidade da vida em "Inspirado em Lope de

\footnotetext{
${ }^{373}$ V. Capítulo 2.

374 ALONSO, Dámaso. Estudios y ensayos gongorinos. Op. cit., p. 24.

${ }^{375}$ CURTIUS, Ernest Robert. Literatura européia e Idade Média Latina. Trad. Teodoro Cabral e Paulo Ronái. São Paulo: Hucitec: Edusp, 1996, p. 195-1966.
} 
Vega" e principalmente em "Tempo de Quevedo", peça importante na concepção da História em Tempo espanhol:

Quevedo, a angústia do tempo

Informa tua visão concreta.

A Espanha sem relógio mede o tempo

No instrumento elíptico da caveira.

Mas o último anjo, matemático,

Virá para reunir a caveira geral,

Virá para ceifar todo o angelismo:

Empunhando a trombeta construída

Com implacável certeza,

Medida e timbre justos,

Fará o homem se conhecer

Nos seus limites precisos.

O tempo se medirá, concreto,

Depois de esgotada a clepsidra.

E tua angústia do tempo

- Tansitório Quevedo que já foste -,

Aferida a rigor, torna-se vã.

Saberás. Saberás. (PCP, 597)

A representação do "fim dos tempos", comum em obras como Tempo eternidade e Poesia liberdade, retorna em Tempo espanhol avaliada pelas diretrizes de sua poética: matemático, construída, justos, rigor. O que é direcionado a Quevedo vale para as outras figuras da coletânea, "transitórias" e que "já foram", as quais, no Juízo Final, encontrarão a eternidade.

\section{Os arredores da História}

Depois de uma parte tão essencial e antes de enfrentar o século $X X, 8$ poemas indiretamente percorrem mais de dois séculos de História da Espanha. Longa e penosa trajetória, que envolveu, entre outros acontecimentos, a decadência do Império espanhol, a invasão napoleônica e a desastrosa guerra com os EUA em 1898. Enquanto houve na pintura a grandiosidade de Goya ${ }^{376}$, nas letras, a inadaptação e a estagnação da tradição espanhola frente ao Neoclassicismo e ao

${ }^{376}$ V. Capítulo 4. 
Romantismo. Porém, no final do século XIX, assiste-se ao início de uma recuperação, como por exemplo a "Pedra de Unamuno". Além disso, a resistência do espanhol revela-se na permanência da tauromaquia, com os poemas "O rito cruento" e "Na corrida".

Por outro lado, o primeiro e último poemas dessa seqüência - "Chuva em Castela" e "Pueblo", ambos selecionados para a Antologia poética de 1964 ampliam a noção de História em Tempo espanhol.

Ao se voltar à meseta castelhana, o poeta abandona, por um momento, a sua típica secura:

A história circula insatisfeita

Ao largo da planície autárquica.

Entre a marcha das amapolas

Se orientam

Se levantam

Os pés aquedutos.

Chove a galope

Cavalos horizontais

Sacando o preto do branco

Chovem a galope.

Alturas compactas se procuram.

Parte-se o galope em fragmentos. (PCP, 600)

O fragmento inicial, por meio da cara associação a Murilo, tempo-espaço, sintetiza um período no qual a Espanha não encontrara seu rumo. Diante do presente estéril, as imagens pontuam-se entre o remoto passado e a espera do porvir: o aqueduto, ruína da ocupação romana, e a forte chuva, rara e desejada na região. Simultaneamente, vislumbram-se o fim e o começo.

Quanto a "Pueblo", remete-nos às pequenas populações da Espanha de todos os tempos:

O pueblo subsiste no ar, no sol de poeira,

Nos quadrados de cal e na secura.

Subsiste na conversa organizada

Em torno da água pública da fonte. 
Um som qualquer ressoa prolongado

No ouvido de animal, pessoa ou casa.

Os minutos pacientes limam os dias.

O pueblo destacando-se da história

Participa do obscuro de cada um.

E participam todos deste pueblo

Que rejeitando a idéia do aniquilamento

Joga aos dados a ressurreição da carne. (PCP, 604)

Não estamos mais diante das cidades repletas de História, que possuem identidade peculiar, para a qual um nome já diz muito - Ávila, Segovia, Toledo, etc. - mas sim do pueblo anônimo, de qualquer parte do território espanhol. Ainda assim, subsiste - palavra próxima da resistência que percorre a coletânea - tanto no meio físico, quanto no modo de vida comunitário.

O poema descreve a quase imobilidade e silêncio do pueblo, os quais induzem a uma lenta passagem do tempo cronológico. A parada momentânea no desfile artístico e urbano vem reforçar a linha mestra de Tempo espanhol. Embora esteja à margem da História oficial, isso não impede a "subsistência" eterna do pueblo, pois aposta, no fim dos tempos, na "ressurreição da carne".

\section{Tempo andaluz}

Na quarta parte - segundo a divisão aqui proposta - de Tempo espanhol, 12 poemas concentram-se na Andaluzia. "Paisagem com figuras", para retomar o título e a proposta de Cabral, onde a História quase não comparece, a não ser quando se refere ao domínio árabe em Granada:

\footnotetext{
(...)

Tu me deste séculos de outrora rudes estandartes

O gênio africano enxertado no castelo da Europa,

A tensão de duas culturas díspares;

$E$ no limite desse tempo épico

A certeza geométrica da cruz. (PCP, 610)
} 
Murilo investiu em um passado próximo do observador, seja para o "passante" de Sevilha, o cante flamenco ou os Jardins do Generalife. Tanto que, diferentemente de outros momentos da coletânea, a $1^{\text {a }}$ pessoa toma mais direitos frente ao objetivismo descritivo da $3^{\text {a. }}$ : basta verificar a seção 2 de "Tempo de cante flamenco", com a repetição em cada estrofe de "Eu no flamenco". Aliás, como o título do poema indica, trata-se de um tempo marcado pelo ritmo do canto e da dança, continuamente renovado. E o poeta integra-se de tal modo à vitalidade desse universo, que por um instante desafia a morte, como no final do poema "Granada": "Os minutos aumentados aprestavam os dentes:/ E tive gana da vida, não quis morrer para sempre." (PCP, 611) Assim, podemos considerar o penúltimo momento de Tempo espanhol como uma intensificação dos princípios de resistência e transcendência concentrados no presente.

A opção de Murilo pelos contrários fez com que se dirigisse às três cidades andaluzas mais características: "Resulta inútil confrontar Granada, Sevilha e Córdoba, todas fortemente tocadas pelo gênio árabe, mas diversas, opostas mesmo, cada uma com seu timbre intransferível. Entretanto, das três, Granada é a mais espetacular e fantástica, Sevilha a mais feminina e festeira, Córdoba, a mais enxuta e secreta." (PCP, 1181). Vale compará-lo ao depoimento sobre as mesmas cidades de Cabral: "(...) Mesmo cidades como Córdoba, sendo o contrário de Sevilha, têm a mesma força andaluza. (....) É engraçado que, das cidades da Andaluzia, Granada é aquela que menos me interessa. Acho que Granada é uma cidade cenográfica, como a Bahia." ${ }^{377}$ Por isso, além de não ter composto nenhum poema a respeito de Granada, para a Antologia poética de Murilo Mendes em $1966^{378}$, apenas escolheu da parte andaluza o poema "Córdova":

Conheço-te a estrutura tersa,
Toda nervo e osso, contida
Em labirintos de cal
E em pátios de vida secreta,
Córdova áspera e clássica
Alimentada de África.

Como não te entregas de súbito,

Quem te aproxima terá sempre fome

E não dirá: Córdova de meus amores.

\footnotetext{
377 ATHAYDE, Félix, org. Op. cit., p. 17.

378 MENDES, Murilo. Antologia poética. Seleção de João Cabral de Melo Neto. Rio de Janeiro: Fontana; Brasília: INL, 1976.
} 
Um nome seco e esdrúxulo te designa,

Sol desdenhoso, Córdova concreta. (PCP, 610)

Apesar de também não haver dedicado nenhum poema a Córdoba, salvo um significativo "A sevilhana que é de Córdoba"379, Cabral, ao destacar a realização muriliana, manifesta a concordância com uma poética concisa e objetiva.

\section{Tempo de hoje e de sempre na Catalunha}

Nos 13 poemas finais de Tempo espanhol o poeta vai chegando ao tempo que Ihe coube viver em uma região que não se sente Espanha: "(....) A Catalunha atrai-nos pelo seu espírito de independência, sua tradição de anarco-sindicalismo, de lutas operárias, estudantis; e, talvez devido à proximidade da França, pela sua abertura européia. Portanto, quem diz Barcelona diz Catalunha e Europa." (PCP, 1166). Ainda para Murilo, é também Barcelona o berço de grandes artistas da modernidade, como Gaudí, Picasso e Miró. ${ }^{380}$

Em lugar de repassar algum episódio da Guerra Civil Espanhola, em uma coletânea tão marcada pelas letras, fez alusão a ela por meio de dois poetas que morreram durante o conflito: nos poemas "Canto a García Lorca" (Recordando que soubeste/ Defrontar a morte seca/ Vinda no gume certeiro/ Da espada silenciosa) e "Palavras a Miguel Hernández" ("Breve provando a experiência do homem,/ O sangue defrontando o touro aceso,/ O sol negro da prisão e da morte."). Mas isso está longe de significar algum tipo de condescendência com o regime franquista, pois as realizações da última parte de Tempo espanhol representam as mais contundentes e comprometidas de toda a obra muriliana. Não está ao lado do poder, nem do padre que "abençoa a espada", mas sim do povo espanhol: o indignado "chofer de Barcelona", os operários em greve, os estudantes, os prisioneiros, os "padres inconformistas". Mais um motivo para esse espaço privilegiado do livro ser a Catalunha, onde seu nacionalismo tornou-se uma forma de resistência à opressão de Franco:

\footnotetext{
${ }^{379}$ V. Capítulo 5.

${ }^{380}$ Sobre Picasso e Miró, v. Capítulo 4.
} 
O estilo de Barcelona

Formou-se na rebeldia.

Provém de cultura densa

À base de sangue e vida. ("Barcelona", PCP, 614)

Em tal luta, ainda que "subterrânea", a morte é presença inevitável. O "chofer de Barcelona", por exemplo, deseja uma nova Espanha a partir de uma guerra civil, espécie de Apocalipse:

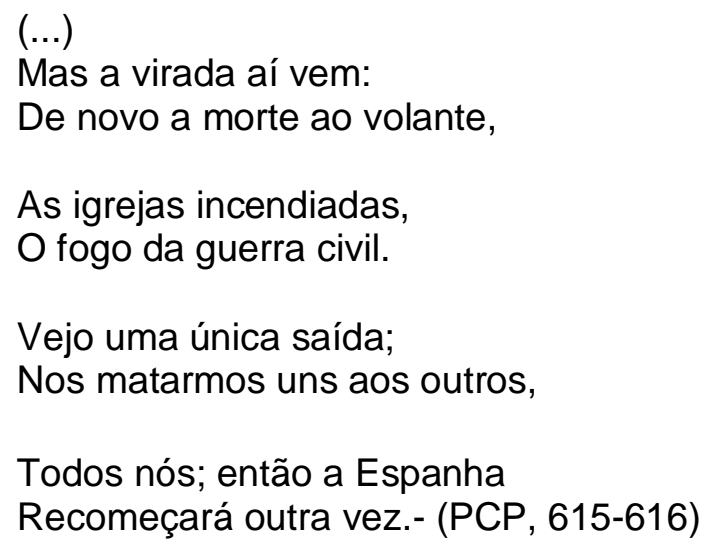

Contudo, alerta-se que o verdadeiro fim virá da ordem divina: "A morte lúcida não virá da espada do homem,/ Antes virá da estocada de Deus." ("O padre cego", PCP, 618). A morte que tanto fascina o espanhol representa apenas o término do tempo e da história:

O real explode com a morte.

A contenção espanhola da morte

Explode em fogo e fim.

Explode a morte agredida pelo espanhol.

Explode o silêncio espanhol da morte.

Morte: tempo físico que explode

Largando a pele da memória,

Tempo da memória que explode

Substantivamente. ("Morte situada na Espanha (La Caridad-Sevilha)"), PCP, 620)

O poema que encerra a coletânea, "O Cristo subterrâneo", mais do que ser o estágio mais recente de uma história em progressão, aponta para sua correlação divina: 


\section{Descubro um Cristo secreto}

Que nasce na Espanha súbito.

Não é o Cristo vitorioso

Dos afrescos catalães, Nem o Cristo de Lepanto

Suspenso por uma torre

De espadas, velas, paixões.

Não investe uma colina,

Não brilha no meio do altar

Entre ornamentos de prata.

Nem no palácio dos ricos,

Nem no báculo dos bispos.

É um Cristo quase secreto

Que nasce das catacumbas

Da Espanha não-oficial.

Nasce da falta de pão,

Nasce da falta de vinho,

Nasce da funda revolta

Contida pela engrenagem

Da roda de compressão.

Nasce da fé maltratada

Vagamente definida.

É um Cristo dos operários

Atentos, em pé de greve,

Filhos de outros operários

Mortos na guerra civil.

É um Cristo dos estudantes

Sem dinheiro para as taxas.

É um Cristo dos prisioneiros

Que no silêncio cultivam

A pura flor da esperança.

É um Cristo de homens-larvas,

Famintos, inacabados,

Morando em covas escuras

De Barcelona e Valência.

É um Cristo do tempo incerto.

É um Cristo do vir-a-ser,

Formado nos corações

Da Espanha que não se vê. (PCP, 620-621)

Se levamos em conta a cosmovisão de Murilo, o "tempo incerto", "o vir-a-ser", não implica apenas na superação da censura e penúria da Espanha franquista, mas principalmente a redenção coletiva no Reino de Cristo. Firmemente ancorado na História e no espaço, o horizonte da eternidade circula por Tempo espanhol. Assim, o poeta atinge o universalismo buscado desde o início de sua obra: o que foi, é e será para os espanhóis, mesmo com eventos e personagens distintos entre si, vale para todos. 


\section{Considerações finais}

$\mathrm{Na}$ ausência de uma história da poesia brasileira do século $\mathrm{XX}$, os trabalhos que aproximem dois ou mais poetas podem contribuir para diminuir essa lacuna. Várias são as possibilidades, e no caso de Cabral e Murilo, ainda escassos. ${ }^{381} \mathrm{~A}$ relação entre ambos, enfatizada por eles próprios e pela crítica ${ }^{382}$, é exemplar nesse sentido: embora fossem muito diferentes, quase contrários - talvez o interesse mútuo surgisse justamente daí - ao longo de suas carreiras não deixaram de ser amigos e trocar experiências. Se o primeiro contato deu-se entre o "mestre" e o "discípulo", quando o Cabral estreante foi buscar elementos para sua poética no Murilo maduro, não demorou muito para se configurar um diálogo entre "iguais", entre dois grandes poetas. Mais do que insistir em uma inversão de posições - a presença de Cabral em Murilo - preferimos pensar em intercâmbios em um momento forte da trajetória deles, que para um vai de $O$ rio (1954) a $A$ educação pela pedra (1961), e, para o outro, de Contemplação de Ouro Preto (1954) a Convergência (1970). Sintomaticamente, durante tal período esteve mais presente a vivência e a transfiguração, nas respectivas obras, do país estrangeiro que os unia entre dissonâncias.

Dessa maneira, o presente estudo pretendeu também desenvolver outro aspecto não muito explorado, o das fontes estrangeiras na poesia brasileira moderna. A incorporação da Espanha na obra de Cabral e de Murilo tornou-se, tanto pela qualidade, quanto pela extensão, um conjunto único na literatura brasileira. Além disso, a pesquisa revelou-nos que eles foram protagonistas decisivos nas relações literárias entre Brasil e Espanha. No lado de cá, voltado ao modelo francês e norte-americano, chamaram a atenção para uma rica tradição literária e novos autores. No país ibérico, reverteram o caminho natural do "centro" para a "periferia": os dois representaram possibilidades altamente bem realizadas de conciliar

\footnotetext{
${ }^{381}$ Para Cabral, v. sua relação com Bandeira em LIMA, Luiz Costa. Sobre Bandeira e Cabral In Intervenções. São Paulo: Edusp, 2002, p. 57-69, e com Drummond em GLEDSON, Jonh. Influências e impasses. Drummond e alguns contemporâneos. São Paulo: Companhia das Letras, 2003, p. 233262. Quanto a Murilo, v. ANDRADE, Fábio de Souza. Jorge de Lima e Murilo Mendes: confluências e divergências In $O$ engenheiro noturno. A lírica final de Jorge de Lima. São Paulo: Edusp, 1997, p. 2967.

${ }^{382}$ V. Introdução.
} 
vanguarda e uma significação humana frente a um contexto dominado por uma poesia "social" limitada esteticamente.

$\mathrm{Na}$ esteira de uma concepção da literatura espanhola ainda corrente no momento em questão, Cabral e Murilo abordaram a Espanha com um estilo marcado pelas noções de "concreto", "objetivo" e "realista", entre outras. Enquanto para Cabral essa apropriação foi fundamental para constituir uma poética muito singular na lírica luso-brasileira, para Murilo serviu como conquista de uma depuração e controle contrários à impulsividade característica de sua produção.

Cabral e Murilo pensaram a Espanha não apenas em uma perspectiva literária, mas também pictórica, plástica, detendo-se em vários artistas que Ihes possibilitassem ratificar suas poéticas. Nos poemas, em particular, desejaram "dar a ver" a Espanha, fosse uma paisagem, uma figura ou um espetáculo, como o flamenco, em imagens sugestivas.

Seguindo a fértil lição da Geração de 27, foram além das vanguardas e se abriram ao popular, como Cabral, e à História, como Murilo. Até mesmo a concepção urbana deles não tinha a ver com a atração cosmopolita do século XX, ao preferirem a Espanha que ainda custava a acertar os ponteiros com a modernidade; por isso retiraram-se à meseta castelhana, ao pueblo, às cidades ao "alcance do corpo".

Para completar, as contradições da Espanha, "exótica" para os demais europeus do outro lado dos Pireneus, seduziram os dois poetas brasileiros que se aventuraram fora de suas fronteiras. Já que não se sentiam tão estrangeiros, não precisavam acentuar as tintas daquilo que era distinto, mas sim buscar dimensões universais, uma ética e um tempo que pertencem a todos os homens e lugares. 


\section{Bibliografia}

\section{Murilo Mendes}

\subsection{Livros}

Poesias. 1925-1955. Rio de Janeiro: José Olympio, 1959.

Antologia poética. Lisboa: Livraria Morais Editora, 1964.

Antologia poética. Seleção de João Cabral de Melo Neto. Rio de Janeiro: Fontana; Brasília: INL, 1976.

Poesia completa e prosa. Edição de Luciana Stegagno Picchio. Rio de Janeiro: Editora Nova Aguilar, 1995.

Recordações de Ismael Nery. $2^{a}$ ed. São Paulo: EDUSP; Editora Giordano, 1996. Tempo espanhol. Rio de Janeiro: Record, 2001.

\subsection{Textos}

"Calunga". Boletim de Ariel. a. 4, n. 11, Rio de Janeiro, ago. 1935, p. 291.

"Manuel Bandeira cai no conto do vigário". Boletim de Ariel. a. 5, n. 2, nov. 1935, p. 38.

"A poesia e os confusionistas". Boletim de Ariel. a. 5, n. 3, Rio de Janeiro, dez. 1935.

"Poesia universal". Boletim de Ariel. a. 7, n. 8, Rio de Janeiro, maio 1937, p. 220221.

"A poesia social". Vanguarda. Rio de Janeiro, 1953. In MEIRELES, Cecilia. Obra poética. Rio de Janeiro: Editora Nova Aguilar, 1987, p. 52-53.

\subsection{Correspondência}

FONSECA, Edson Nery da, org. Cartas a Edson Nery da Fonseca. Recife: Companhia Pacífica, 1995.

GUIMARÃES, Júlio Castañón. Distribuição de papéis: Murilo Mendes escreve a Carlos Drummond de Andrade e a Lúcio Cardoso. Rio de Janeiro: Fundação Casa de Rui Barbosa, 1996. 


\subsection{Fortuna crítica (seleção)}

ANDRADE, Mário de. "A poesia em 1930" In Aspectos da literatura brasileira. São Paulo: Martins, s.d., p. 42-45.

"A poesia em pânico" In $O$ empalhador de passarinho. $4^{\text {a }}$ ed. Belo Horizonte: Editora Itatiaia, p. 49-56.

ANTELO, Raul. Murilo Mendes lê em espanhol In I e I/ Congressos de literatura comparada da UFMG. Belo Horizonte: Imprensa Oficial, 1987, p. 537-554.

ARAÚJO, Laís Corrêa de. Murilo Mendes: ensaio crítico, antologia, correspondência. São Paulo: Perspectiva, 2000.

ARRIGUCCI JR., Davi. "Arquitetura da memória" In $O$ cacto e as ruínas: a poesia entre outras artes. São Paulo: Duas Cidades, Editora 34, 2000, p. 95-150.

BARBOSA, João Alexandre. "Convergência poética de Murilo Mendes" In A metáfora crítica. São Paulo: Editora Perspectiva, 1974, p. 117-136.

CAMPOS, Haroldo de. "Murilo e o mundo substantivo" In Metalinguagem \& outras metas. $4^{a}$ ed. São Paulo: Perspectiva, 1992, p. 65-75.

CANDIDO, Antonio. "Pastor pianista / pianista pastar" In Na sala de aula. Caderno de análise literária. $8^{a}$ ed. São Paulo: Ática, 2002, p. 81-95.

FRIAS, Joana Matos. O erro de Hamlet: poesia e dialética em Murilo Mendes. Rio de Janeiro: 7 Letras; Juiz de Fora: Centro de Estudos Murilo Mendes - UFJF, 2002.

LEWIN, Willy. "Saudação a Murilo Mendes". Boletim de Ariel. Rio de Janeiro, a. 3, n. 12, set. 1934, p. 321.

LIMA, Luiz Costa. "Tríptico sobre Murilo Mendes" (Murilo Mendes: da dispersão à intensidade, Murilo Mendes em seu começo e $O$ agônico na abertura de Contemplação) In Intervenções. São Paulo: Edusp, 2002, p. 71-110.

LINS, Álvaro. "Murilo Mendes: o positivo e o negativo na originalidade" In Os mortos de sobrecasaca. Ensaios e estudos 1940-1960. Rio de Janeiro: Civilização Brasileira, 1963, p. 46-50.

MERQUIOR, José Guilherme. "Murilo Mendes ou a poética do visionário". In Razão do poema. Ensaios de crítica e estética. de Janeiro: Civilização Brasileira, 1965, p. 51-68.

"A pulga parabólica" In A astúcia de mímese: ensaios sobre crítica. Rio de Janeiro: Topbooks, 1997, p. 218-225. 
MOURA, Murilo Marcondes. Murilo Mendes: a poesia como totalidade. São Paulo: EDUSP: Giordano, 1995.

"Os jasmins da palavra jamais" In BOSI, Alfredo, org. Leitura de poesia. São Paulo: Ática, 1996, p. 101-123.

NEHRING, Marta Moraes. Murilo Mendes: crítico de arte. São Paulo: Nankin Editorial, 2002.

PICCHIO, Luciana Stegagno. "Itinerário poético de Murilo Mendes". Revista do Livro. INL. a. 4, n. 16, Rio de Janeiro, dez. 1959, p. 61-73.

\subsection{Catálagos e volumes coletivos}

Catálogo da exposição Murilo Mendes: acervo. Juiz de Fora: UFJF/CEMM, 1999.

GUIMARÃES, Julio Castañon, org. Murilo Mendes: 1901-2001. Juiz de Fora: CEMM/ UFJF, 2001.

Ipotesi. Revista de estudos literários. v. 6, n.1, Juiz de Fora, 2002.

PEREIRA, Maria Luiza Scher, org. Imaginação de uma biografia literária: os acervos de Murilo Mendes / SILVA, Teresinha Vânia Zimbrão da, org. Chronicas mundanas e outras crônicas: as crônicas de Murilo Mendes. Juiz de Fora: EDUFJF, 2004.

RIBEIRO, Gilvan Procópio e NEVES, José Alberto Pinho. Murilo Mendes: o visionário. Juiz de Fora: EDUFJF, 1997.

RODRIGUES, Marisa Timponi P., org. Magnelli; mostra do acervo do Centro de Estudos Murilo Mendes. Juiz de Fora: CEMM/UFJF, 1998.

\section{João Cabral de Melo Neto}

\subsection{Livros}

Serial e antes. Rio de Janeiro: Nova Fronteira, 1997.

A educação pela pedra e depois. Rio de Janeiro: Nova Fronteira, 1997.

Prosa. Rio de Janeiro: Nova Fronteira, 1998.

$O$ arquivo das Indias e o Brasil; documentos para a história do Brasil existentes no Arquivo das Indias de Sevilha. Rio de Janeiro: Ministério das Relações Exteriores, Seção de Publicações, 1966. 


\subsection{Textos}

"Prática de Mallarmé”. Renovação. a. 4, n. 1. Nova Série. Recife, out-nov-dez 1942.

\subsection{Correspondência}

RODRIGUES, Lêda Boechat, org. João Cabral de Melo Neto. 1957-1959. Correspondência de José Honório Rodrigues. Rio de Janeiro: Academia Brasileira de Letras, 2000.

SÜSSEKIND, Flora, org. Correspondência de Cabral com Bandeira e Drummond. Rio de Janeiro: Nova Fronteira, Fundação Casa de Rui Barbosa, 2001.

\subsection{Tradução de literatura espanhola}

BARCA, Calderón de la. Os mistérios da missa. Coleção Universitária de Teatro. v. 1. Rio de Janeiro: Civilização Brasileira, 1963.

LORCA, Federico Garcia. A sapateira prodigiosa. Rio de Janeiro: Agir, 1951.

\subsection{Fortuna crítica (seleção)}

ATHAYDE, Félix de, org. Idéias fixas de João Cabral de Melo Neto. Rio de Janeiro: Nova Fronteira: FBN; Mogi das Cruzes, SP: Universidade de Mogi das Cruzes, 1998.

BARBOSA, João Alexandre. "Linguagem \& Metalinguagem em João Cabral" In $A$ metáfora crítica. São Paulo: Editora Perspectiva, 1974, p. 137-159.

A imitação da forma: uma leitura de João Cabral de Melo Neto. São Paulo: Duas Cidades, 1975

"Sevilha, objeto de paixão" In Entre livros. Cotia, SP: Ateliê Editorial, 1999, p. 223-229.

João Cabral de Melo Neto. São Paulo: Publifolha, 2001.

BEDATE, Pilar Gómez. "La Revista de Cultura Brasileña: João Cabral de Melo Neto y Ángel Crespo". Revista de Cultura Brasileña. Madri, jun. 1997, p. 21-39. 
BOSI, Alfredo. "Fora sem dentro? Em torno de um poema de João Cabral de Melo Neto". Estudos Avançados. v. 18, n. 50, São Paulo, 2004, p. 195-207.

CAMPOS, Haroldo de. "O Geômetra engajado" In Metalinguagem \& outras metas. $4^{\mathrm{a}}$ ed. São Paulo: Perspectiva, 1992, p. 77-88.

CANDIDO, Antonio. "Poesia ao norte" In Textos de intervenção. Edição de Vinícius Dantas. São Paulo: Duas Cidades; Ed. 34, 2002, p. 135-142.

CARONE, Modesto. A poética do silêncio: João Cabral de Melo Neto e Paul Celan. São Paulo: Perspectiva, 1979.

CASTELLO, José. João Cabral de Melo Neto: o homem sem alma. Rio de Janeiro: Rocco, 1996.

CRESPO, Ángel e BEDATE, Pilar Gómez. Realidad y forma en la poesía de Cabral de Melo. Separa da Revista de Cultura Brasileña. n. 8, Madri, março 1964.

ESCOREL, Lauro. A pedra e o rio. Uma intrepretação de João Cabral de Melo Neto. Rio de Janeiro: ABL, 2001.

GARCIA, Othon M. "A página branca e o deserto" In Esfinge clara e outros ensaios. $2^{\mathrm{a}}$ ed. Rio de Janeiro: Topbooks, 1996, p. 177-265.

GLEDSON, John. “Sono, poesia e o 'livro falso' de João Cabral de Melo Neto: uma reavaliação de Pedra do Sono In Influências e impasses: Drummond e alguns contemporâneos. São Paulo: Companhia das Letras, 2003, p. 170-200.

GUIMARÃES, Julio Castañon. Cabral falando. Teresa revista de Literatura Brasileira. Área de Literatura Brasileira. FFLCH. USP. n. 3, Ed. 34, 2002, p. 304-307.

HOLANDA, Sérgio Buarque de. "João Cabral de Melo Neto", "Branco sobre negro" e "Equilíbrio e invenção" In O espírito e a letra. Estudos de crítica literária. v. 2. 1948-1959. Edição de Antonio Arnoni Prado. São Paulo: Companhia das Letras, 1996, p. 516-531.

HOUAISS, Antônio. "Sobre João Cabral de Melo Neto" In Drummond mais seis poetas e um problema. Rio de Janeiro: Imago,1976, p. 203-227.

LIMA, Luiz Costa. "A traição conseqüente ou a poesia de Cabral" In Lira e antilira: Mário, Drummond, Cabral. $2^{a}$ ed. Rio de Janeiro: Topbooks, 1995, p. 197-331.

"Sobre Bandeira e Cabral" e "João Cabral: poeta crítico" In Intervenções. São Paulo: Edusp, 2002, p. 57-69; 111-134.

LINS, Álvaro. "João Cabral de Melo Neto: primeiros sinais de um poeta original em sua geração" In Os mortos de sobrecasaca. Ensaios e estudos 1940-1960. Rio de Janeiro: Civilização Brasileira, 1963, p. 57-59. 
MAMEDE, Zila. Civil geometria: bibliografia crítica, analítica e anotada de João Cabral de Melo Neto, 1942-1982. São Paulo: Nobel/ Edusp/ INL/ Vitae, Governo do Estado do Rio Grande do Norte, 1987.

MERQUIOR, José Guilherme. "Serial" e "Onda mulher e onde a mulher". In: Razão do poema. Ensaios de crítica e de estética. Rio de Janeiro: Civilização Brasileira, 1965, 89-101.

"Nuvem civil sonhada - ensaio sobre a poética de João Cabral de Melo Neto" In $A$ astúcia de mímese: ensaios sobre lírica. $2^{\mathrm{a}}$ ed. Rio de Janeiro: Topbooks, 1997, p. 84-187.

NUNES, Benedito. João Cabral de Melo Neto. $2^{\text {a }}$ ed. Petrópolis: Vozes, 1974.

PEIXOTO, Marta. Poesia com coisas (uma leitura de João Cabral de Melo Neto). São Paulo: Perspectiva, 1983.

SECCHIN, Antonio Carlos. João Cabral: a poesia do menos. São Paulo: Duas Cidades; Brasília: INL, 1985.

VILLAÇA, Alcides. "Expansão e limite da poesia de João Cabral". In BOSI, Alfredo, org. Leitura de poesia. São Paulo: Ática, 1996, p. 143-169.

\subsection{Números especiais}

Colóquio/ Letras. Paisagem tipográfica. Homenagem a João Cabral de Melo Neto (1920-1999). n. 157/158, Lisboa, jul-dez. 2000.

Cadernos de Literatura Brasileira. Instituto Moreira Salles. n. 1, março de 1996.

\section{Espanha ${ }^{383}$}

ALBERTI, Rafael. Entre el clavel y la espada (1939-1940). Buenos Aires: Losada, 1941. (MM) Pleamar (1942-1944). Buenos Aires: Losada, 1944. (MM) Poesía (1924-1944). $2^{a}$ ed. Buenos Aires: Editora Losada, 1946.

\footnotetext{
${ }^{383}$ A sigla MM indica que o exemplar pertence à biblioteca de Murilo Mendes (Centro de Estudos Murilo Mendes - Juiz de Fora).
} 
La arboleda perdida. v. 2. Tercero y cuarto libros (1931-1987). Madri: Alianza Editorial, 2002.

ALEIXANDRE, Vicente. Espadas como labios. Pasión de la tierra. Buenos Aires: Losada, 1957. (MM)

Prosa. Edição de Alejandro Duque Amusco. Madri: Espasa Calpe, 1998.

ALONSO, Damaso. Hijos de la ira. Buenos Aires: Espasa Calpe,1946. (MM)

Poesía española: ensayo de métodos y límites estilísticos. Madri: Gredos, 1950. (MM)

Estudios y ensayos gongorinos. Madri: Gredos, 1955. (MM)

Poetas españoles contemporáneos. Madri: Gredos, 1958. (MM)

Góngora y el Polifemo. 2 vols. $4^{\mathrm{a}}$ ed. Madri: Gredos, 1961. (MM)

"Góngora entre sus dos centenarios (1927-1961)" In Cuatro poetas españoles

(Garcilaso-Góngora-Maragall-Antonio Machado). Madri: Gredos, 1962.

ARTILES, Joaquín. Los recursos literarios de Berceo. Madri: Gredos, 1964.

AZORíN. Obras escogidas. v. 2. Ensayos. Edição de Miguel Ángel Lozano Marco. Madri: Espasa Calpe, 1988.

BALLESTA, Juan Cano. La poesía española entre pureza y revolución (1920-1936). Madri: Siglo Veiniutno, 1996.

BARCA, Pedro Calderón de la. La vida es sueño. $27^{a}$ ed. Edição de Ciriaco Morón. Madri: Cátedra, 2001.

BARENYS, Natàlia, org. Epistolari Rosa Leveroni-Josep Palau i Fabre. Barcelona: Publicacions de L'Abadia de Montserrat, 1998.

BERCEO, Gonzalo de. La vida de Santo Domingo de Silos. Edição de Brian Dutton. Londres: Tamesis Books, 1978.

Signos que aparecerán antes del Juicio final. Duelo de la Virgen. Martirios de San Lorenzo. Edição de Arturo M. Romoneda. Madri: Castalia, 1980.

Milagros de Nuestra Señora. 10ª ed. Edição de Michael Gerli. Madri: Cátedra, 1999.

BODINI, Vittorio. I poeti surrealisti spagnoli. Torino: Einaudi, 1963. (MM)

BROSSA, Joan. Ball de sang (1941-1954). Barcelona: Editorial Crítica, 1982.

Sonets de Caruixa. Barcelona: Edicions 62, 1990.

Poesia i prosa. Edição de Glòria Bordons. Valencia: L'estel 3 i 4, 1995.

BUCHHOLZ, Elke Linda. Francisco de Goya. Vida e obra. Colonia: Könemann, 2001. 
CANO, José Luis. "Corazón en la tierra - Alfonso Pintó". Ínsula. a. 3, n. 35, Madri, 15 nov. 1948 , p. 5.

, org. Antología de la nueva poesía española. Madri: Gredos, 1958. (MM)

"La poesía brasileña en España (Noticia bibliografica)". Revista de Cultura Brasileña. n. 2, Madri, 1962, p. 116-121.

CARBONELL I ESTELLER, Eduard et alli. Guía arte románico. Barcelona: Museu Nacional d'Art de Catalunya, 1998.

CARRIEDO, Gabino-Alejandro. Nuevo compuesto descompuesto viejo (Poesía 1948-1978). Madri: Peralta, 1980.

CARVALHO, Agda. A imagem poética hispânica no Brasil: a contribuição pictórica de Isabel Pons, Pedro Tort, Fernando Odriozola e Joan Ponç. Tese de doutorado. ECA - USP, 2002.

CASSOU, Juan. El Greco. Trad. José López y López. Barcelona: Ediciones Hymsa, 1934. (MM)

CASTELLET, José María, org. Veinte años de poesía española. 1939-1959. Barcelona: Seix Barral, 1960. (MM)

CIRLOT, Sandra Miranda. Tàpies. Madri: Susaeta, 2001.

COOK, Walter William Spencer e RICART, José Gudiol. Ars Hispaniae. Historia Universal del Arte Hispánico v. 6. Pintura e imagenería románicos. Madri: Ed. Plus-Ultra, 1950. (MM)

COROMINAS, Joan e PASCUAL, José A. Diccionario crítico etimológico castellano e hispánico. v. 4. Madri: Gredos, 1981.

COSSIO, Manuel B. El Greco. $2^{\mathrm{a}}$ ed. Madri: Espasa-Calpe, 1948. (MM)

CRESPO, Ángel Antología poética. Edição de Arturo Ramoneda. Madri: Alianza Editorial, 1994.

Poesía. v. 1. Edição de Pilar Gomez Bedate e Antonio Piedra. Valladolid: Fundación Jorge Guillén, 1996.

Los trabajos del espíritu. Diarios (1971-1972/ 1978-1979). Edição de Pilar Gómez Bedate. Barcelona: Editorial Seix Barral, 1999.

DABIT, Eugène. Les maitres de la peinture espagnole: El Greco-Velazquez. $4^{\mathrm{a}} \mathrm{ed}$. Paris: Gallimard, 1937. (MM)

DE LA ENCINA, Juan. Goya: su mundo histórico y poético. México: La Casa de España en México, 1939. (MM) 
DIEGO, Gerardo, org. Poesía española. Antología 1915-1931. Edição fac-simil de 1932. Madri: Visor Libros, 2002.

DOLFI, Laura, org. Cartas inéditas (1953-1983). Jorge Guillén - Oreste Macrí. Valencia: Pre-Textos, 2004.

D'ORS, Eugenio. La bien plantada. Trad. Rafael Marquina, 1911.

El Romancero viejo. 19ª ed. Edição de Mercedes Díaz Roig. Madrid, Cátedra, 1999. FREBERIX, Pierre. Goya. Paris: L'artisan du livre, 1928. (MM)

GARCÍA-POSADA, Miguel. Los poetas de la generación del 27. $2^{\mathrm{a}}$ ed. Madri: Anaya, 2000.

GÓMEZ-MORENO, Manuel. El entierro del conde de Orgaz. Barcelona: Editorial Juventud, 1951. (MM)

GÓNGORA, Luís de. Poemas y sonetos. Buenos Aires: Editorial S.A., 1939. (MM) Romances y letrillas. Buenos Aires: Losada, 1939. (MM) Las soledades. $3^{\mathrm{a}}$ ed. Madri: Sociedad de Estudios y Publicaciones, 1956. (MM)

GUARDIOLA, Carles-Jordi, org. Cartes de Carles Riba. v. 2. 1939-1952. Barcelona: Institut d'edutis catalans, 1991

GUILLÉN, Jorge. Lenguaje y poesía. Madri: Revista de Occidente, 1962. (MM) A la altura de las circunstancias. Buenos Aires: Sudamericana, 1963. (MM) Final. Edição de Antonio Piedra. Madri: Castalia, 1989. Cántico. $4^{\mathrm{a}}$ edição. Barcelona: Seix Barral, 1998. Notas para una edición comentada de Góngora. Edição de Antonio Piedra e Juan Bravo. Valladolid: Fundación Jorge Guillén/ Universidad de Castilla-La Mancha, 2002.

Homenaje. Reunión de vidas. Edição fac-simil. Madri: Visor Libros, 2003.

LAMILLAR, Juan. Joaquín Romero Murube: la luz y el horizonte. Sevilha: Fundación José Manuel Lara, 2004.

La poesía del flamenco. Litoral. Revista de arte, poesía y pensamiento. n. 238, Málaga, 2004.

LECHNER, J. El compromiso en la poesía española del siglo XX. Alicante: Publicaciones de la Universidad de Alicante, 2004.

LORCA, Federico Garcia. Poeta en Nueva York. Conferencias. Prosas póstumas. Buenos Aires: Editorial Losada, 1942. (MM) 
MACHADO, Antonio. Poesías completas. Edição de Manuel Alvar. Madri: Espasa Calpe, 2003.

MANENT, Marià. "Notes sobre libres". Ariel. a. 2, n. 9, Barcelona, abril 1947, p. 31.

MARQUÉS, María José Mas. Picasso. Madri: Susaeta, 2000.

MARTÍN, Domènec Ribot. Miró. Madri: Susaeta, 2000.

MIRÓ, Joan. Escritos y conversaciones. Margit Rowell, ed. Valencia-Murcia: Institut Valencià d'art modern - Colegio Oficial de Aparejados y Arquitectos Técnicos de la Región de Murcia, 2002.

MURUBE, Joaquín Romero. Obra selecta. v. 1. Silencios de Andalucía (Lírica y Narrativa). Edição de Jacobo Cortines e Juan Lamillar. Sevilha: Fundación José Manuel Larra, Diputación de Sevilla, Ayuntamineto de Sevilla e Fundación El Monte, 2004.

Obra selecta. v. 2. Los cielos perdidos (Prosa ensayística). Edição de Jacobo Cortines e Juan Lamillar. Sevilha: Fundación José Manuel Larra, Diputación de Sevilla, Ayuntamineto de Sevilla e Fundación El Monte, 2004.

OLIVER, Conxita. Cuixart. Antológica. Barcelona: Generalitat de Catalunya; Visual, 1995.

ORTEGA, Manuel J. Ramos, org. La copa de los sueños: poetas surrealistas andaluces. Sevilha: Fundación José Manuel Lara, 2005.

ORTEGA Y GASSET, José. Papeles sobre Velázquez y Goya. Madri: Revista de Occidente, 1950. (MM)

Velázquez. Madri: Espasa Calpe, 1963. (MM)

PAGÈS I SANTACANA, Mònica. Cuixart. Biografia inacabada. Barcelona: Parsifal Edicions, 2003.

PARIENTE, Ángel. Diccionario bibliográfico de la poesía española del siglo XX. Sevilha: Renacimiento, 2003.

PENA, María del Carmen. Pintura de paisaje e ideología. La generación de 98. Madri: Taurus, 1998.

PERMANYER, Lluís. Brossa x Brossa. Records. Barcelona: Edicions La Campana, 1999.

PERUCHO, Joan. "Dos llibres de Josep Palau Fabre". Ariel. a. 2, n. 14, Barcelona, dez. 1947, p. 116-117.

PIDAL, Ramón Menéndez. Poesía juglaresca y juglares. Orígenes de las literaturas románicas. Madri: Espasa Calpe, 1991. 
PIEDRA, Antonio e AIRES, Carlos Martín, coordenação. Ángel Crespo. Con el tiempo, contra el tiempo. Fundación Jorge Guillén et alli, 2005.

PUIG, Arnau, FORNS, Manuel Pérez-Lizano e HERRADOR I RODRIGUES, Juan Ramon. García Vilella. Barcelona: Ámbit, 2004.

Poema de Mio Cid. 18 ed. Edição de Colin Smith. Madrid: Cátedra, 1993.

Rafael Santos Torroella. En los márgenes de la poesía y el arte. Salamanca: Fundación Salamanca Ciudad de Cultura, 2004.

RIBA, Carles. Obres completes. v. 1. Poesia. Edição de Enric Sullá. Barcelona: Edicions 62, 1984.

RICO, Francisco, org. Historia y crítica de la literatura española. v. 6. Modernismo y 98. José-Carlos Mainer, org. Barcelona: Crítica, 1980.

Historia y crítica de la literatura española. v. 7. Época contemporánea. 19141939. Víctor G. de la Concha, org. Barcelona: Crítica, 1984.

ROMEU I FIGUERAS, Josep. “Joan Barat: Poemes. - Barcelona, 1947”. Ariel. a. 2, n. 10, Barcelona, jun. 1947, p. 48.

ROZAS, Juan Manuel. La generación del 27 desde dentro. $2^{\mathrm{a}}$ ed. Madri: Istmo, 1986.

SAN JUAN DE LA CRUZ. Obras escogidas. Edição de Ignacio B. Anzoátegui. $2^{\mathrm{a}}$ ed.

Buenos Aires: Espasa Calpe, 1945. (MM)

Poesía. 11 $1^{\mathrm{a}}$ ed. Edição de Domingo Ynduráin. Madri: Cátedra, 2000.

SCHOLZ-HÄNSEL, Michael. El Greco. Colonia: Taschen, 2004.

TAPIÈS, Antoni. Memoria personal. Fragmento para una autobiografía. Trad. Javier Rubio Navarro e Pere Gimferrer. Barcelona: Seix Barral, 2003.

TUSÓN, Vicente. La poesía española de nuestro tiempo. Madri: Anaya, 1990.

UNAMUNO, Miguel de. Obras completas. v. 1. Paisajes y ensayos. Madri: Escelicer, 1966.

WOLF, Nobert. Velázquez. Colonia: Taschen, 2000.

\section{Geral}

ANDRADE, Fábio de Souza. O engenheiro noturno. A lírica final de Jorge de Lima.

São Paulo: Edusp, 1997.

ANTELO, Raúl. Literatura em revista. São Paulo: Ática, 1984.

AUERBACH, Erich. Figura. Trad. Duda Machado. São Paulo: Editora Ática, 1997. 
BOSI, Alfredo. História concisa da literatura brasileira. $34^{\text {a }}$ ed. São Paulo: Cultrix, 1994.

CRESPO, Angel. "La poesía neomodernista". Brasil. Publicación del Servicio de Propaganda y Expresión Comerical. Embaixada do Brasil. a. 3, n. 10-12, Madri, out.-dez. 1963.

CRESPO, Ángel e BEDATE, Pilar Gómez. "Situación de la poesía concreta". Revista de Cultura Brasileña. n. 5, Madri, jun. 1963, p. 89-130.

"Planteamiento de una encuesta sobre la literatura brasileña de vanguardia". Revista de Cultura Brasileña. n. 11, Madri, dez. 1964, p. 333-338.

CURTIUS, Ernest Robert. Literatura européia e Idade Média Latina. Trad. Teodoro Cabral e Paulo Ronái. São Paulo: Hucitec: Edusp, 1996.

GANTEFÜHRER-TRIER, Anne. Cubismo. Colonia; Barcelona: Taschen, 2004.

HANSEN, João Adolfo. "Vieira: Tempo, Alegoria e História". Brotéria. n. 145, Lisboa, 1997, p. 541-556.

"Barroco, neobarroco e outras ruínas". Teresa revista de literatura brasileira. Área de Literatura Brasileira. FFLCH - USP. São Paulo: Editora 34, n. 2, 2001, p. 10-66.

HIKMET, Nazim. Poèmes de Nazim Hikmet. Paris: Les editeurs français réunis, 1951.

KOIFMAN, Georgina, org. Cartas de Mario de Andrade a Prudente de Moraes, neto. 1924/1936. Rio de Janeiro: Nova Fronteira, 1985.

LAFETÁ, João Luiz. 1930: a crítica e o modernismo. São Paulo: Duas Cidades; Editora 34, 2000.

LEWIN, Willy. Quinze Poemas. Recife, 1936.

De um diário de poesia. Renovação. a. 2, n. 2, Recife, março 1940, p. 22; a. 2, n. 5, Recife, ago. 1940, p. 10.

LOPEZ, Telê Ancona. A biblioteca de Mário de Andrade: seara e celeiro da criação. In Fronteiras da criação: anais do $6^{\circ}$ Encontro Internacional de Pesquisadores do Manuscrito. São Paulo: Annablume: Fapesp, 2000, p. 139-162.

MASSI, Augusto. Militante bissexto: o crítico Pudente de Moraes, neto. Tese de Doutorado. FFLCH - USP, 2004.

MEIRELES, Cecília. Crônicas de viagem. v. 2. Edição de Leodegário A. de Azevedo Filho. Rio de Janeiro: Nova Fronteira, 1999. 
RAYMOND, Marcel. De Baudelaire ao surrealismo. Tradução de Fúlvia M. L. Moretto e Guacira Marcondes Machado. São Paulo: Edusp, 1997 
Anexos 


\section{Brasil e Catalunha}

João Cabral de Melo Neto, poeta e diplomata brasileiro que reside aqui ao serviço do seu país, assimilou em pouco tempo bastante elementos da nossa cultura para nos dar, com as suas traduções de algumas Tannkas de Carles Riba, uma mostra da sua sensibilidade singular e amiga. Eis aqui uns exemplos de como, de poeta a poeta, não há segredos em idiomas irmãos:

TANNKA XIII
Direi limões, maçãs rosadas, rosas, sal e conchas, e pensarão que passas entre os jardins e a onda. ${ }^{384}$

Corresponde a:

Diré llimones, pomes rosades, roses, sal i petxines, i es pensaran que passes entre els jardins i l'ona.

TANNKA XXXVI
Tristes bandeiras do crepúsculo! Contra elas sou púrpura viva.
Um coração serei, na escuridade;
de novo púrpura, com a alba. ${ }^{385}$

No original:
Tristes banderes
del crepuscle! Contra elles
sóc porpra viva.
Seré un cor dins la fosca;
porpra de nou amb l'alba. ${ }^{386}$

\footnotetext{
${ }^{384}$ Trata-se de um dos "Tannkas de les quatre estacions", intitulado "Eugenia".

${ }^{385}$ A tradução enviada por Cabral a Bandeira, em carta de 20 de julho de 1948, além de apresentar o título - "Inscrição sobre um retrato oferecido em tempos de guerra" - revela variações: "Tristes bandeiras/ do crepúsculo! Contra elas sou/ púrpura viva./ Um coração serei, na escuridade;/ de novo púrpura, com a aurora." (SÜSSEKIND, Flora, org. Op. cit., p. 91)

${ }^{386} \mathrm{O}$ título original é "Inscripció Sobre un retrat ofert a J. i A. En temps de guerra".
} 
TANNKA XXXVIII

Como quem repousa

no amor ou na onda,

dormes, filho

da guerra, no inumerável

regaço ausente da fuga. ${ }^{387}$

Tradução de:

Com qui reposa

en l'amor o en l'onada,

fill de la guerra,

dorms en la innumerable

falda absent de la fuga. ${ }^{388}$

João Cabral imprimiu, pessoalmente e em sua casa, o seu livro de versos Psicologia da composição, onde aprofunda rumo à personalidade do poeta com uma nítida austeridade de expressão e um lirismo que se mantém na linha das proximidades Guillén-Riba e de certa manera, Valéry.

[TRIADÚ, Joan. Ariel. Revista de les arts. a. 3, n. 16, Barcelona, abril 1948, p. 40.]

${ }^{387}$ A tradução enviada por Cabral a Bandeira, em carta de 20 de julho de 1948, intitula-se "Criança refugiada adormecida" (SÜSSEKIND, Flora, org. Op. cit., p. 91) 


\section{Quinze poetas catalães ${ }^{389}$}

Introdução e tradução de João Cabral de Melo Neto

Quis a Revista Brasileira de Poesia apresentar em suas páginas uma série de quinze poetas catalães, dos que venho estudando e traduzindo já alguns anos. Nesta série, vão apenas os poetas nascidos depois do início do século XX. A data, aliás, não foi escolhida por nenhum motivo especial e sim, unicamente, pela necessidade de limitar uma determinada quantidade de versos, suscetível de ser publicada num só número de revista.

Como disse, o princípio do século $\mathrm{XX}$ não está aqui como critério psicológico. Na verdade, a posição dos poetas catalães incluídos nesta antologia não difere essencialmente dos poetas catalães imediatamente anteriores, isto é, dos poetas que vieram depois de Josep Carner, nascido em 1884, entre os quais se encontra, por exemplo, o mestre de quase todos os que são aqui dados a conhecer: Carles Riba, em minha opinião o autor mais considerável da língua catalã. Algum dia apresenterei, também, uma outra série desses poetas mais antigos e, especialmente, uma seleção de poesias desse mesmo Riba, cuja transposição para a língua portuguesa tenho a ponto de concluir.

A ter que definir a posição dos poetas posteriores a Carner, eu diria, sem que desrespeite por isso as diferenças individuais de cada um deles, que é a sua uma posição de defesa, defesa tensa, da língua catalã. O já mencionado Carner foi talvez o primeiro poeta a ter consciência da situação especialíssima do idioma de que servia, uma vez que a longa - e importante - série de autores que promoveram a Renascença*, de Verdaguer (n. em 1845) a Maragall (n. em 1860), estiveram sempre condicionados pelo deslumbramento dessa voz ressuscitada, ao mesmo tempo que prejudicados por uma concepção demasiado romântica da literatura e dos fenômenos da linguagem.

\footnotetext{
${ }^{388}$ O título original é "Infant refugiat adormit".

389 Publicado na parte "Anexos" do livro Correspondência de Cabral com Bandeira e Drummond (SÜSSEKIND, Flora, org. Op. cit., p.277-309). Incluímos as pequenas biografias da seção "Os poetas deste número" - provavelmente redigidas pelo próprio Cabral -, com correções e acréscimos, além de indicar a obra que integra o poema e possíveis variantes.

A Renascença a que faço alusão, aqui, é o ressurgimento da língua catalã como idioma literário, realizado em meados do século XIX, após séculos de uma absoluta hibernação provocada por circunstâncias históricas.
} 
Invocar a situação da língua catalã é absolutamente importante para justificar tal definição, por ser, afinal de contas, a poesia, primordialmente, um uso da linguagem. Pois o fato dessa língua românica, falada (e não exclusivamente) por cinco milhões de poessoas, própria de uma região que se caracterizou sempre por uma situação geográfica de passagem (passagem de guerreiros, na reconquista; de mercadores e soldados; passagem entre Castela e a França, a Itália, o Oriente), ter sido obrigada sempre a defender seu caráter próprio contra influências numerosas e poderosas, me parece suficiente para explicar a fisionomia atual dessa poesia, à qual o conhecimento das novas teorias relativas à existência da linguagem se veio acrescenter, dando-Ihe o aspecto presente que a faz uma poesia mais de professores e filólogos do que de jornalistas, de conscientes mais do que inspirados.

Modernamente, é fácil compreender-se uma maior crispação verificada nessa atitude de autodisciplina e lucidez, se tomamos em conta a porcentagem de pessoas não catalãs que acorrem atualmente à Catalunha, atraídas por possibilidades de vida mais fácil numa região altamente industrializada; e (fato este último mais importante para os poetas mais jovens ou em elaboração), se levarmos em conta o fato de ser esta uma língua já não ensinada nas escolas, só impressa em livros de caráter puramente literário e, absolutamente, desprovida de imprensa; e, finalmente, se nos damos conta do que tudo isso representa de negativo para a existência de um idioma e, portanto, de uma literatura.

Evidentemente, em tais condições, não é possível, sem o grande risco de estar escrevendo em outro idioma, uma atitude romântica de abandono à pura espontaneidade e uma cega - ou, mais justamente, enceguecida - entrega ao impulso de criar.

Até aqui, observações objetivas. E, agora, se me é permetida uma parte de julgamento, eu diria que essa atual posição a que foram levados os escritores catalães - uma posição materialista diante da criação poética - talvez contenha uma sugestão digna de ser considerada por parte de poetas de outros idiomas não ameaçados.

[Revista Brasileira de Poesia. a. 2, v. 1, n. 4, São Paulo, fev. 1949.] 
1. Mariano Manent

Lloança del fang

Louvação do barro

Lloaré el fang, per ço que hi fou la vida

Cantarei o barro, porque nele esteve a vida $i$ aquella sang que bull al nostre cos. e este sangue que ferve em nosso corpo.

Mos ulls de fang pressenten el repòs Meus olhos de barro pressentem o repouso i la immortal claoror de l'altra Vida. e o clarão imortal de uma outra vida.

Lloaré el fang, per ço com fou pastada Cantarei o barro porque foi amassada la nostra carn del fang inconscistent a nossa carne do barro inconsistente i dins l'argila immóbil i colrada e na argila curtida e inanimada el buf de déu entrà com la sement. o sopro de Deus entrou como a semente.

Nasceu em Barcelona em $1898^{390}$. Viagens por quase toda a Europa. Fundador da Revista de Poesia e de Quaderns de Poesia. [Faleceu em 1988]. Livros publicados: La branca, 1918; La collita de la boira, 1920; L'aire daurat, 1928; L'ombra, $1931^{391}$. É autor ainda de uma grande antologia da poesia inglesa contemporânea, traduzida por ele mesmo para o catalão e castelhano. [O poema "Lloança del fang" integra a obra La branca. Poemes (1916-1918). Segundo a edição consultada (La acacias salvajes. Edição bilingüe catalão/ espanhol de Alex Susanna. Trad. José Agustín Goytisolo. Barcelona: Edciones del Mall, 1986, p. 24), transcrevemos as seguintes variantes: 1: Lloaré el fang que un dia fou veire de la vida, $\square$ 2: d'aquell 5: Llloaré el fang, perquè va ser pastada $\square 6$ : inconsistent, $\square 7$ : immòvil $\square$ 8: Dèu]

\footnotetext{
390 No periódico consta "1900".

${ }^{391}$ No periódico consta "1930".
} 
2. Joan Oliver (Pere Quart)

N. $X I X$

(Les Decapitacions)

Sens tija, sola,

corol.la

que em la nit serena

vola,

errivola

ànima em pena,

livida

(com son visatge

a la bella vida).

Maridatge

d'ala i neu,

fruit celeste,

(testa

sacra

de Madama

Anna Bolena

rediviva em simulacre)

cendra i flama,

Iluna plena.
Poema XIX

De As Decapitações

Sem caule, só

corola

que na noite serena

voa, errante

alma penada,

lívida

(como seu rosto

de despedida

à bela vida).

Casamento

de asa e neve,

fruto celeste

(cabeça

sacra

de Madame

Ana Bolena

rediviva em simulacro),

cinza e chama,

lua plena.

Nasceu em Sabadell, cidade da província de Barcelona, em 1899 ${ }^{392}$. Publicou alguns livros com o pseudônimo de PEDRO QUARTO. Exilado de Espanha desde a Guerra civil. [Faleceu em 1986]. Publicou: Uma tragèdia a Lil.liput, 1928; Les decapitacions, 1934; Cataclisme, 1935; Allò que tal vegada s'esdevingué, 1936; Oda a Barcelona, 1936; Bestiari, 1936; Contraban, 1937. Obteve o Prêmio Folguera no ano de 1936. [Segundo a edição consultada (Obra poética. Barcelona: Edicions Proc, 1975, p. 35), transcrevemos as seguintes variantes: Epígrafe: "Sweets to sweet farewell", de Shakespeare $\square$ 1: Sens tija, sola $\square$ 2: corolla $\square$ 4: vola $\square 5$ : donivola $\square$ 6: ànima en pena; $\square 10$ : a bella vida). $\square 12$ : d'ala de neu, $\square$ 14: testa $\square$ 16: madama $\square$ 18: rediviva en simulacre, $\square$ 19: cendra i flama]

${ }^{392}$ No periódico consta "1900". 


\section{Tomás Garcés}

Llegenda

Cavallers de barba blanca

per un aspre viarany.

Potser tornen de cacera,

poteser van a guerrejar

Canyes altes i florides.

un bressol vora el canyar.

Entre flors de satalia,

el somriure de l'Infant.

Descavalquen, s'agenollen, si el sabessin bressolar!

Amb la boira s'esvaïen

la cacera i el combat.

Neixen albes, cauen fulles, passen aigües riu enllà. Pels camins de la ribera, sense brides, els cavalls.
Lenda

Cavaleiros de alvas barbas na vereda a cavalgar.

Talvez regressem da caça, talvez partam a guerrear.

Capinzal alto e florido, um berço no capinzal. Entre flores, rosas brancas, o Infante sorrindo está.

Descavalgan, se ajoelham, se o soubessem embalar! Com a névoa se dissiparam o combater e o caçar.

Nascem albas, tombam folhas, águas no rio a passar. Nos caminhos da ribeira, cavalos, sem brida, já.

Nasceu em Barcelona em 1901. Bacharel em Direito e Licenciado em Filosofia. [Faleceu em 1993]. Livros publicados: Vinte cançons, 1922; L'ombra del lledoner, 1924; El somni, 1927; Paradis, 1931: Notes sobre poesia, 1933; El senyal, 1935; El caçador, 1947. [Datado de 1944, o poema "Llegenda" foi publicado na obra Grèvol $i$ molsa. Vint-i-quatre poemes de Nadal (1953). Segundo a edição cosultada (Poesia completa. Edição de A. Susanna. Barcelona: Columna, 1986, p. 293), transcrevemos as seguintes variantes: 1: Cavallers de barba blanca. $\square$ passen aigües riu enllà] 


\section{Rosa Leveroni}

Cançó

Totes les albes há encès

el clam ardent d'una flama.

Tots els estels han donat

un plor subtil de rosada.

El perfum posa carmí

al cor de la rosa blanca

i la daina, dins la font,

cercava un mirall de plata.

He sentit uma cançó

i no sé qui la cantava:

semblava venir de lluny

entre sospirs com de branca

i deia ben dolçament:

Ai la trista enamorada!...

\section{Canção}

Mil auroras acendeu

o ardente grito da chama.

Dez mil estrelas nos deu

o pranto sutil do orvalho.

Punha o perfume carmim

na alma desta rosa branca

e uma cerva pela fonte

buscava o espelho de prata.

Percebi uma canção

e não sei quem a cantava:

entre suspiros de ramos,

como de longe, chegava,

dizendo bem docemente:

Ai da triste enamorada!...

Nasceu em Barcelona, em 1910. Bibliotecária da Biblioteca da Universidade de Barcelona. [Faleceu em 1985]. Livro publicado: Epigrames i cançons, 1938. [Esta "Cançó" foi publicada sob o título "Dotze cançons (fragments) XI" na revista Ariel (a. 2, n. 12, Barcelona, set.-out. 1947, p. 76). Posteriormente, foi recolhida em Epigrames i cançons. Não registramos variantes.] 


\section{Bartomeu Rosseló-Pòrcel}

A Mallorca, durant la guerra civil

Verdegen encara aquells camps

i duren aquelles arbredes

i damunst del mateix atzur

es retallen les meves muntanyes.

Allí les pedres invoquen sempre

la pluja difícil, la pluja blava

que ve de tu, cadena clara,

serra, plaer, claror meva!

Sóc avar de la llum que em resta dins els [Ils

i que em fa tremolar quan et recordo!

Ara els jardins hi són com músiques

i em torbem, em fatiguem com em un tedi lent.

El cor de la tardor já s'hi marceix, concertad amb fumeres delicades.

I les herbes es cremen a turons de cacera, entre somnis de setembre i boires entintades de capvestre.

Tota la meva vida es lliga a tu com en la nit les flames a la fosca.
A Maiorca, durante a guerra civil

Reverdecem ainda aqueles campos

e permanecem aqueles arvoredos

e sobre o mesmo azul

se recortam as minhas montanhas.

Ali as pedras invocam sempre

a chuva difícil, a chuva azul

que vem de ti, cordilheira clara,

serra, prazer, claridade minha!

Sou avaro do que me resta de tua luz e que me faz estremecer quando te evoco! Ali os jardins são agora como a música e me turbam, fatigam com seu tédio lento.

Ali o coração do outono já murcha em harmonia com fumeiros delicados. $E$ as ervas são queimadas pelos cerros de caça, entre sonhos de setembro e névoas tingidas de ocaso.

Toda a minha vida se liga a ti, como na noite, as chamas à treva.

Nasceu em Ciutat de Mallorca, Maiorca, em 1913. Estudos universitários em Barcelona e Madrid, na célebre Residência de Estudantes onde viveram Lorca, Alberti e outros poetas antes da Guerra Civil. Faleceu em 1938 ${ }^{393}$. Livros publicados: Nou poemes, [1933]; Quaderns de sonets, [1934]; Imitació del foc (póstumo), [1938]. ["A Mallorca, durant la guerra civil", datado de "Barcelona, setembre 1937", foi publicado na coletânea Imitació del foc. Segundo a edição consultada (Obra poética. Edição bilingüe catalão/ espanhol de Joan Mas y Vives. Trad. Xavier Rodríguez Baixeiras. A Coruña: Espiral Maior, 2002, p. $118)$, registramos as seguintes variantes: 3 : damunt $\square$ 17: capvesre]

${ }^{393}$ No periódico consta "1937". 
6. Joan Teixidor

Infant

Tots les jardins s'han fet per tu, i les flors i les pedres.

No intentis saber més; mira la llum penjada a l'arbre.

Quan seràs gran oblidaràs aquesta pau divina.

I, sense esment, tindrás enyor del que ara tens $i$ et sobra.
Menino

Todos os jardins se fizeram para ti e as flores, as pedras.

Não tentes saber mais, contempla a luz pendurada na árvore.

Quando grande, não te lembrarás desta paz divina.

Mas uma obscura saudade haverá no desejo do que agora te sobra.

Nasceu em Olot, província de Gerona, em 1913. Licenciado em Filosofia. Jornalista profissional, crítico literário e artístico. [Faleceu em 1992]. Livros publicados: Poemes, [1932]; Joc partiti, [1935]; L'aventura fràgi, [1937]; Camí dels dies, 1948. [O poema "Infant" encontra-se na coletânea Camí dels dies. Segundo a edição consultada (Miscel.lània poètica. Olot: Edicions Municipals, 1988, p. 57), registramos a seguinte variante: 3: més: mira] 


\section{Salvador Espriu}

Monolac de Esther

Quant et perdis endins

del desert de la tarda

it'assedegui el balu

de la mar tan llunyana,

et sentiràs mirtat

per la meva mirada.

Etern príncep, Jacob,

tindràs sempre companya

que peregrini amb tu

por segles e paraules.

Suportaràs la mort,

com a l'ocell la branca.

$A i$, enemic cami

de les hores i l'aigua,

galop d'altius arquers

contraris a l'estàtua

de sal de qui volgué

esdevenir de marbre!

Si et tombes, els teus ulls

glaçaran esperances.

Poble trist, amb record

de ciutats molt cremades.

No t'acull cap repòs

d'ombra bona, de casa.

Només somnis, al fons

de la meva mirada.
Monólogo de Esther

Quando te perderes dentro

do deserto da tarde

e te der sede o azul

do mar tão distante,

sentirás que és olhado,

pelo meu olhar.

Eterno príncipe, Jacob, terás sempre companhia

contigo peregrinando

através séculos, palavras

Suportarás a morte

como o ramo ao pássaro

Ai, inimigo caminho

das horas, das águas,

galope de altivos archeiros

contrários à estátua

de sal do que pensou

vir a ser mármore!

Se tu cais, os teus olhos

gelarão esperanças.

Povo triste, à lembrança

das cidades abrazadas.

Nenhum repouso te acolhe

de sombra doce, ou casa.

Apenas sonhos, no fundo

do meu olhar.

Nasceu em 1913, na cidade de Santa Coloma de Farners, província de Gerona. Autor de livros de contos, novelas e peças de teatro. [Faleceu em 1985]. Sua obra poética se compõe de diversos livros, entre os quais Cementiri de Sinera, [1948], talvez o mais importante. [O "Monolac de Esther" pertence ao terceiro fragmento da peça Primera història d'Esther. Improvisació per a titelles (1948), publicado pela primeira vez na revista Ariel (a. 3, n. 16, Barcelona, abril de 1948, p. 32). Não registramos variantes.] 
8. Joan Vinyoli

Al vent de tardor

Vent de tardor, vent solitari,

vent de la nit,

obscura força que es deslliga

de l'infinit i torna a l'infinit,

arremolina't dintre meu, conjura

contra el meu cor la teva força,

arrenca já l'escorça

del fruit que no madura.
Ao vento de outono

Vento de outono, vento solitário, vento da noite, força obscura que se desprende do infinito e volta ao infinito, rodopia dentro de mim, conjura contra meu coração tua força, arranca de uma vez a casca do fruto que não madura.

Nasceu em Barcelona em 1914. Formação autodidata. Perfeito conhecedor da literatura alemã. Tradutor de Rilke, Hölderlin, Nietzche e Hofmann. [Faleceu em 1984]. Publicou: El primer desenllaç, 1937. [O poema "Al vent de tardor" faz parte do livro De vida i somni (1948). Segundo a edição consultada (Obra poètica completa. Edição de Xavier Maciá. Barcelona: Edicions 62, 2001, p. 40) o título é "Vent de tardor".] 
9. Josep Romeu i Figueras

Juny

Junho

Més nobles que l'or, el blats

Nobres, mais do que o ouro, as espigas

oscil.len, madurs, i onegem, oscilam, maduras, e ondulam

revenen i van al vent

e vêm e vão ao vento,

en tardes sagrades, dolces,

em tardes sagradas, doces.

Esperen avui la falç

Esperam agora a foice

per dar-se sumisos i amples.

para dar-te submissas, largamente.

Sabéssim l'amour del fruit

Conhêcessemos o amor do fruto

que serva la mel profunda

que recolhe o mel profundo

i cau, nodriment de Déu, e cai, alimento de Deus,

en fer-se madur i perfecte.!

ao fazer-se maduro, completo!

Nasceu em Ódena, província de Barcelona, em 1917. Licenciado em Línguas Românicas pela Universidade de Barcelona. Primeiro Prêmio do Concurso Montserratino, em 1942. [O poema "Juny" foi publicado no livro Terra (1943). Segundo a edição consultada (Tots els poemes. Barcelona: Columna, 1953, p. 57), transcrevemos as seguintes variantes: 1: els $\square 2$ : oscil.len, fimbrants $\square$ 3: revénen $\square$ 4: en tardes sagrades, dolces. $\square$ 6: submisos $\square$ 7: ¡Sabéssim l'amour del fruit] 
10.Josep Palau i Fabre

Sonet intrauterí

Des del teu mal, des de la teva entranya, dels de les teves llàgrimas, vull ser uma veu-germinal.

Pensar-te des de tu, des del teu centre dir-te, des de la flor suprema dels teus ulls.

Jo vul desnéixer en tu.Tot home vol desnéixer en un amor, un si.

Ah! fes-me petit petit, fins que jo sigui pols estremida, pol. len del teu ventre.
Soneto intrauterino

Desde teu mal, desde tua entranha, desde tuas [lágrimas quero ser uma voz - germinal.

Pensar-te desde ti, desde teu centro contar-te, [desde a flor suprema de teus olhos.

Quero desnacer em ti. Todo homem quer [desnacer num amor, num seio.

Ah! faze-me pequeno, pequeno, até que eu seja enfebrecido, pólen de teu ventre.

Nasceu em Barcelona, em 1917. Estudos de Letras na Universidade desta cidade. Atualmente vive na França, onde se incorporou ao movimento existencialista. Livros publicados: L'aprenent de poeta. Imitació de Rosseló-Pòrcel, [1943]; Càncer, [1946]. [O poema "Sonet intrauterí" foi publicado em Càncer. Segundo a edição consultada (Poemes de l'Alquimista. Edição bilingüe catalão/ espanhol. Trad. Juan Goytisolo. Barcelona: Galaxia Gutemberg/ Círculo de Lectores, 2002, p. 230), o poema apresenta-se em uma única estrofe de 4 versos que correspondem as 4 frases.] 
11. Joan Barat i Creus

Any Nou

Ano Novo

Mitja nit, cendra

Meia-noite, epílogo

i epíleg d'un tros de mi

e cinza de um pouco de mim

i del temps: reprendre

e do tempo; outra vez empreender

uma sang i un camí um sangue e um caminho

etern, sense comprendre.

eterno, sem entender.

Nasceu em Barcelona, em 1918. Formação autodidata. [Faleceu em 1996]. Publicou Poemes, 1947. [O poema "Any Nou" encontra-se na obra Poemes, na qual não registramos variantes.] 
És per aixó que estimo

Marbre o lluna glaçada, errívola, com pensatiu asfòdel navegues per un cel [d'esperança

mentre tes mans ignoren les macilentes febres, els horrors de la mort sobre el fang o la injúria envilida que sota encoratjadoras paraules adrecen els homes a llurs amants secrets.

Jo voldria estimar-te com el delicat insecte estima la petita memòria o com la terra estima el nùvol, [d'una flor tombat serenament a uma armoniosa presència que perduri en la llum del teu cos tan esvel i tan jove.

Però somni que atança somni, vida que alena vida no perdona uma boca, uma inútil tortura; no perdora un amor que arrela com um arbre furiosamente alçat damunt d'un ventre o una terra materna.

És per això que estimo aquesta canço que ara agonitza.
É por isso que estimo

Mármore ou lua gelada, errante, como pensativo asfódelo navegas por um céu [de esperança enquanto tuas mãos ignoram as macilentas os horrores da morte sobre o lodo [febres, ou a injúria vil que sob encorajadoras palavras dirigem os homens a suas amantes secretas.

Desejaria estimar-te como o delicado inseto estima a pequena [memória de uma flor

ou como a terra estima a nuvem prostado serenamente ante uma harmoniosa que perdura na luz de teu corpo [presença tão esbelto e jovem.

Porém o sonho que aproxima sonho, vida que alenta vida não perdoa uma boca, uma inútil tortura; não perdoa um amor que se enraíza como [árvore alçada furiosamente por cima de um ventre ou de uma terra materna.

É por isso que estimo esta canção que ora agoniza.

Nasceu em Barcelona em 1920. Magistrado. [Faleceu em 2003]. Publicou Sota la sang, 1947. [O poema "Ès per aixó que estino" foi publicado na obra Sota la sang. Segundo a edição consultada (Obres completes. v. 8. Poesia. Barcelona: Edicions 62,1996 , p. 29), registramos as seguintes variantes: 15 : atansa $\square 22$ : aquesta vella canço] 
13. Joan Triadú

Endimion (Fragment)

Encara és un repòs de les ferides

que láire es llevi, pàtria, del seu son

cansat i taciturn, amic a penes

de les fràgils banderes, dels cabells

més àgils d'un amor, i del somriure

del nostre mar encès de pur matí, vora la vida. Sempre m'acompanyen

els silencis amics i el cansament

més dolç del seu parlar, quan l'abraçada

pobla els arenys de fruit, ric d'una mort

bens guardada en els anys i les lluites,

i em torna les banderes en el vent

de l'espattla segura i exaltada,

mentre els infants ara, amb els ulls de nit, aspiren la claror del cel salvatge,

i no respon una veu a llur crit,

però fugen ocells de benvinguda.

\section{Endimião (Fragmento)}

É ainda um repouso às feridas

que o ar desperte, pátria, de seu sonho cansado e taciturno, amigo apenas

de fragéis bandeiras, dos cabelos

mais agéis de um amor, e do sorriso

do nosso mar - aceso de pura manhã,

ao lado da vida. Sempre me acompanham

os silêncios amigos e essa fadiga

tão doce de seu falar, rico de uma morte

bem guardada nos anos e nas lutas

- quando um abraço povoa as areias dos frutos

e me devolve as bandeiras no vento

do ombro seguro e exaltado;

enquanto as crianças agora, com olhos de noite,

aspiram o clarão do céu selvagem, sem que uma voz responda ao seu chamado que serve apenas para afugentar os pássaros

[de boas-vindas.

Nasceu em Ribes de Freser, província de Gerona, em 1921. Licenciado em línguas clássicas. Tradutor de Píndaro. Atualmente vive em Liverpool, de cuja Universidade é leitor de catalão. Publicou Endimió, 1948. [O fragmento de Endimió (Barcelona: Editorial Ariadna, 1948, p. 17) apresenta as seguintes variantes: 11: ben 1 13: l'espatlla] 
14. Jordi Sarsanedas

Posaré el meu amor...

Posaré el meu amor que és tan llarg co les

[venes

a la boca cendrosa d'aquell infant esquerp entre la pau humil de les darreres cabres. Vull besar aquella fam que li afina la passa i posar um somni lleu en el cani rapat i el reflexe darrer de la nostra mimosa.
Colocarei o meu amor

Colocarei o meu amor, tão longo como as veias, na boca de cinza daquele menino esquivo entre a paz humilde das derradeiras cabras. Quero abraçar a fome que lhe dá aquele passo [sutil, pousar um sonho leve na sua cabeça rapada e o reflexo da flor da nossa mimosa.

Nasceu em Barcelona, em 1924. Realizou estudos universitários em sua cidade natal em em Paris. Sem livro publicado. [O poema titulado por Cabral trata-se da $11^{\mathrm{a}}$ estrofe de "Goigs fragmentaris de Barcelona nostra" do livro $A$ trena de sorra (1945-1948) (1948). Segundo a edição consultada (Fins a un cert punt. Poesia 1945-1989. Barcelona, Edicions 62, 1989, p.22, registramos as seguintes variantes: 1: amor, que és tan llarg co les venes, $\bullet$ : reflex] 
Viure amb fe cada hora santa...

Viure amb fe cada hora santa, com si a l'endemà partíssim cap a un país estranger, sense comiats l'hora nostra.

I arrencar del cel la pluja, $i$ el temps dels teus ulls, amiga, ocell, flor de neu, per mirar-te.

Oh el ritme greu de la Mort! La Mort en els meus cabells, segura com uma rosa.
Viver com fé...

Viver com fé cada hora santa como se amanhã partíssemos para um país estrangeiro, sem despedir a hora nossa.

E arrancar do céu a chuva, e de teus olhos o tempo, amiga, pássaro, flor de neve, para contemplar-te.

Oh o ritmo grave da Morte! A Morte nos meus cabelos presa como uma rosa.

Nasceu em Barcelona, $1927^{394}$. Estudante de Direito. Não tem livro publicado. [O poema integra a coletânea Fidelitad (1948). Segundo a obra consultada (D'allà on ve la veu 1951-1957. Seguit de la reedició de Fidelitat. Barcelona: Els llibres de l'Ossa Menor, 1958, p. 48) registramos a seguinte variante: 10: rosa!]

${ }^{394}$ No periódico consta "1924". 
A bailarina

A bailarina feita

de borracha e pássaro

dança no pavimento

anterior do sonho.

A três horas de sono,

mais além dos sonhos,

nas secretas câmaras

que a morte revela.

Entre monstros feitos

A tinta de escrever

a bailarina feita

de borracha e pássaro.

Da diária e lenta

borracha que mastigo.

Do inseto ou pássaro

que não sei caçar.
La Ballarina

La ballarina feta

De goma i ocella

Balla sobre el trespol

Anterior del somni

A tres hores de son.

Més enllà dels somnis

En les secretes cambres

Que revela la mort

Entre monstres sorgits

De la tinta d'escriure

La ballarina feta

De la goma i l'ocella:

De diària i lenta

Goma que mastego

De l'ocell o l'insecte

Que no vaig a caçar 
As nuvens são cabelos

crescendo como rios;

são os gestos brancos

da cantora muda;

são estátuas em vôo

à beira de um mar;

a flora e a fauna leves

de países de vento;

são o olho pintado

escorrendo imóvel;

a mulher que se debruça

nas varandas do sono;

são a morte (a espera da)

atrás dos olhos fechados;

a medicina, branca!

nossos dias brancos.
Els núvols són cabell

Creixent con les riuades;

Són el gest blanquinós

De la cantora muda;

Són estàtues en vol

Al riberal d'un mar;

Flora i fauna lleugeres

De llunys països de vent;

Són l'ull pintat

Degotant inmòbil;

La dona que s'atansa

A la barana del son;

Són la mort (l'espera de)

Darrera els ulls tancats;

La metgia, blanca!

En blanc, els postres dies. 
(pintura de Monteiro, V. do R.)

A luz de três sóis

ilumina as três luas

girando sobre a terra

varrida de difuntos.

Varrida de defuntos

mas pesada de morte:

como a água parada,

a fruta madura.

Morte a nosso uso

aplicadamente sofrida

na luz desses sóis

(frios sóis de cego);

nas luas de borracha

pintadas de branco e preto;

nos três eclipses

condenando o muro;

no duro tempo mineral

que afugentou as floras.

E morte ainda no objeto

(sem história, substância,

sem nome ou lembrança)

abismando a paisagem,

janela aberta sobre

o sonho dos mortos.
La llum de tres sols

Il lumina tres llunes

Rodant sobre la terra

Exempta de difunts.

Exempta de difunts

Però amb pesadesa de mort:

Com l'aigua estancada

El fruit madur.

Mort per a usar nosaltres

Aplicadament soferta

En la llum d'aquests sols

(Sols gelius d'un $\mathrm{cec}$ );

En les llunes de goma

Pintades blanc i negre;

En els tres eclipses

Condemnant el mur;

En l'estiu mineral

Que arruixá les flores.

I mort també em l'objecte

(sense història, sustància,

sense nom ni remenbrança).

Abismant el paisatge

Finestra oberta sobre

Els somnis dels morts.

[Dal au set. Barcelona. jul.-ago.-set. 1949. Não constam os poemas originais em português.] 


\section{Tapiès, Cuixart, Ponç}

Se a obra de Miró traz à pintura uma linguagem e uma sensibilidade especiais - pessoais - ela constitui, sobretudo, uma luta para dar à pintura uma mecânica nova. Essa luta se define negativamente: mais que impor outro sistema de composição, ela trata de se defender do conjunto das leis de composição estabelecidas pelo Renascimento e completadas depois, dentro do mesmo espírito. Trata de se defender de tudo o que se dirige a assegurar o esqueleto dessa pintura renascentista: rigidez e equilíbrio, estática do quadro.

Essa luta (e é luta e luta dolorosa porque se dá contra leis que se entranharam no hábito, nas mãos e nos olhos dos pintores) vem a ser, assim, uma luta para garantir aos artistas a liberdade de compor. Liberdade de entregar-se a seu jogo fora dessas ou daquelas receitas de equilíbrio. Liberdade para desassociar as idéias de compor e equilibrar. Liberdade para dar à idéia de equilíbrio un sentido de maior riqueza que o da simples estabilidade de pesos.

Dessa liberdade de composição, conseguida por Miró em seus melhores momentos, com muito maior freqüência a partir de 1940 ou 41, parecem começar a tirar proveito os três jovens pintores que agora expõem. Parece que a obra de Miró constituiu para eles o testemunho de um tipo de composição menos rígida; parece que Ihes demonstrou serem possíveis outras composições, além das meras variações do estatismo; que era possível a liberdade de sintaxe onde o formalismo moderno havia conquistado unicamente a liberdade da metáfora.

O que caracteriza estes três pintores, de mitologia e linguagem tão diversos, é, portanto, o fato de coincidir em tipos de composição igualmente independentes da composição estática tradicional. Mas essa caracterização se oferece pelo lado negativo, porque o estado de espírito com que abordam essa liberdade é absolutamente distinto nos três. Tapiès a possui sem buscar suas razões e implicações; e usa dela sem se dar conta. Cuixart parece ter consciência clara dela, e inclusive se encontra interessado em defendê-la. Ponç, por último, menos instintivo do que Tapiès e menos intelectual que Cuixart, mantém-se numa atitude intermediária e não a ignora, mas tampouco a considera como ponto de partida.

E do mesmo modo que são diferentes os estados de espírito com que empregam essa liberdade, são diversos, no terreno estrito da composição, os

resultados a que os três chegam. É diferente, por ejemplo, o comportamento de 
cada um dos três em relação à moldura, ou melhor, com o limite da superfície do quadro. (Todos sabemos a importância do limite do quadro na composição tradicional; e que a partir dele é quando se establece, de fora para dentro, o trabalho de equilibrar e fixar o conjunto.)

Em Tapiès o exercício daquela liberdade se expressa com desprezo às imposições do limite do quadro. Tapiès não pensa, simplesmente não se preocupa com o limite do quadro. Este não é nunca, em sua pintura, o ponto de partida para a composição. E mais de uma vez deve ter se encontrado, inclusive, surpreendido pelo término material de sua tela, término que Ihe terá aparecido, no curso de seu trabalho, quando menos esperava. Sua pintura tira proveito, mais de uma vez, de um raro estremecimento que parecem provocar certos volumes bastante próximos à moldura, certos pesos excesivamente poderosos que ele não se preocupou em neutralizar, procurando-Ihes a distância ideal da moldura que os teria estabilizado. E não é pouco o partido que sua pintura (digo "sua pintura" e não "o pintor", porque Tapiès me parece o menos intelectual dos três que aqui nos ocupam) obtém dessa orden instável, dessa como iminência de catástrofe. O que não constitui um de seus menores encantos, colaborando com o que poderiam chamar as "leis físicas", ou a "gravidade" desse mundo poético tão rico no qual o artista se move permanentemente.

Cuixart, muito mais intelectual, conhece o perigo que se esconde no limite da tela e trata de evitá-lo. Como Ulisses, é fértil em artimanhas. Cuixart evita a consideração do limite. Não é tão instintivo como para poder menosprezá-la e muito astuto para arriscar-se a um corpo a corpo com ela. Cuixart evita a consideração do limite da tela, colocando muita distância entre a moldura e a coisa pintada, diminuindo esta, reduzindo-a a pequenos grupos de coisas dentro de uma superfície muito mais vasta. Procura criar para as coisas que pinta um meio infinito, a fim de impedir que os olhos do espectador, ao contemplar a coisa pintada, tenham seu campo visual condicionado pela moldura. O olho espectador, então, poderá se entregar ao ritmo interno da coisa pintada, que se encontra solta no espaço, à maneira de constelações. O olho não está obrigado a considerar uma superfície determinada, pintada de tal ou qual modo, mas coisas que a superfície cujos limites lhe escapam - mal contém. Distanciar-se da moldura significa, para Cuixart, defender sua liberdade de compor, sua liberdade de entregar-se a coisas e ritmos livres. 
Em Ponç, essa liberdade é, também, de outra orden. Em Tapiès significa o poder de menosprezar qualquer limitação; em Ponç significa poder diminuir até o mínimo o trabalho de compor. Em Cuixart essa liberdade se encontra defendida a cada passo; Ponç a aproveita, possui certa consciência dela, mas despois a esquece. Ele não pinta sua liberdade: se serve dela como de algo que Ihe permite entregar-se mais completamente ao sentido do objeto que pinta. A composição, para ele, é quase sempre um simples aproveitamento econômico da superfície. Quer entregar-se à figura e por isso atribui menos importância à mecânica da tela. Compor, para ele, é preencher a superfície o mais delicadamente possível, pintando símbolos suplementários onde ainda reste espaço livre. Mas a uma liberdade maior de sintaxe tem que corresponder, forçosamente, maior liberdade de metáfora. Em Ponç esta é bem visível na absoluta liberdade com que parece acometer o que mais mostra interessar-Ihe: a figura, livre de qualquer sistema interno conseqüente, de qualquer estilização.

João CABRAL DE MELO

[Cobalto 49. n. 3, Barcelona, 1949. A tradução ao castelhano é de Rafael Santos Torroella.] 


\section{Xilografia popular na Catalunha}

Esporádicas notícias em inventários reais e diocesanos testemunham que a xilografia na Catalunha era conhecida nos séculos XIII e XIV. Estes exemplos, no entanto, não chegaram a nossos dias para que possamos discernir sua origem ou procedência.

Em pleno século XV, na organização social da Catalunha, tem corpo jurídico um grêmio de naipers e estampers; isso demonstra uma arraigada indústria impressora, no momento de ser introduzido entre nós a arte de imprimir propriamente dita. Ao redor de 1470, emigrantes alemães e holandeses passam nossa fronteira portadores do rebento tipográfico.

A plástica germânica tinge com marcado matiz nossa gravura, embora com o Renascimento, a Itália obrigue a constantes vacilações que, junto a uma falta de artistas que produzam originais para ser levados à xilografia, agravam o problema da criação, obrigando aos gravadores a copiar as xilografias importadas ou a inspirar-se nelas.

Todo este caos plástico passa a um cosmos em que se cristaliza, dois séculos mais tarde, a gravura que conhecemos como gravura popular.

É nela que o verdadeiro gravador se livra do jugo do artista e se converte em seu próprio criador, simplifica sua gramática plástica e com o mínimo de recursos técnicos consegue expressar o poético sentido popular da arte. Há quem, equivocadamente, a tem chamado primitiva. $\mathrm{Na}$ verdade é um retorno; as experiências eram demasiado eruditas para resistir à perenidade de sua expressão, para chegar triunfante a este sentido primário e popular da arte.

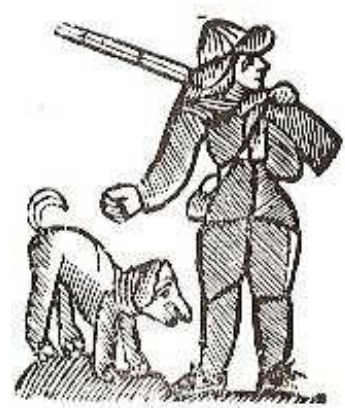




\section{El caçador}

Un matí a trenc d'albada,

jo m'en vaig anar a caçar.

Saltant barrancs i muntanyes

una nina vaig trobar.

Entauleu conversa amb ella, jo l'amor li demaní.

La resposta que ella em feia:

- Caçador, us burleu de mi.

e com ela se funde todo o poético
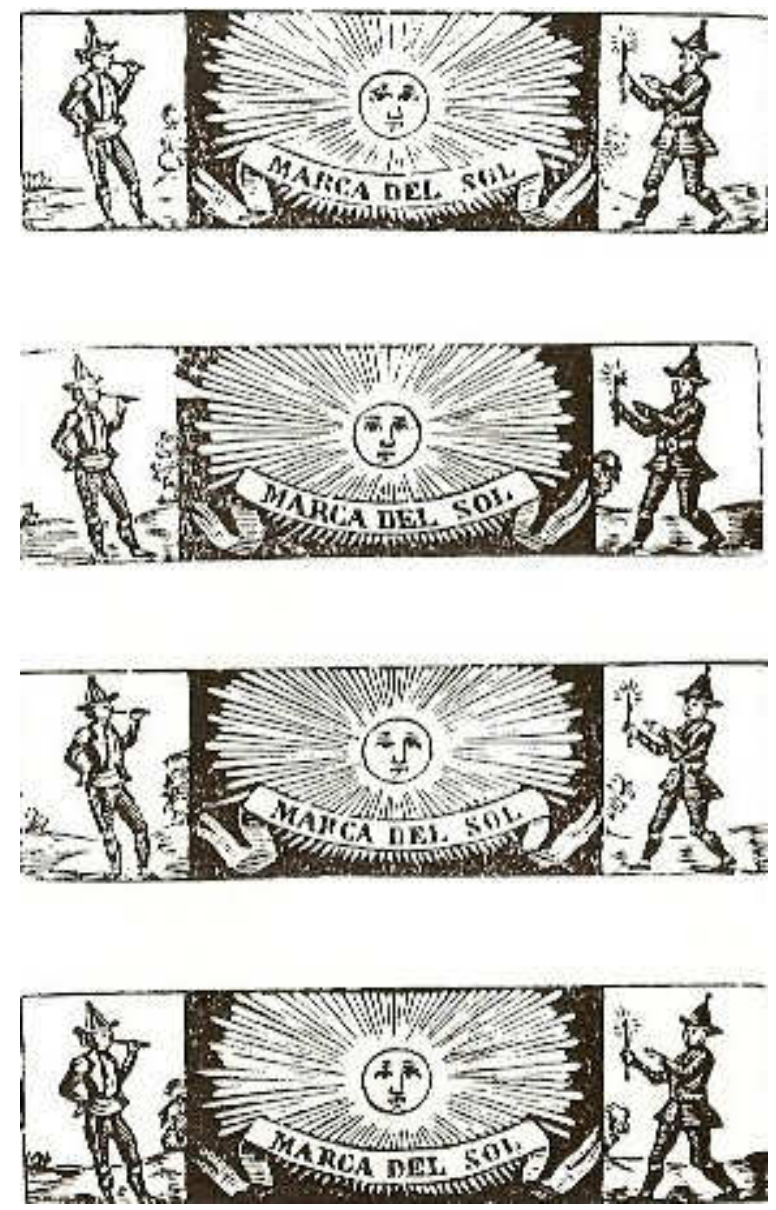

e o poético se infunde na indústria 

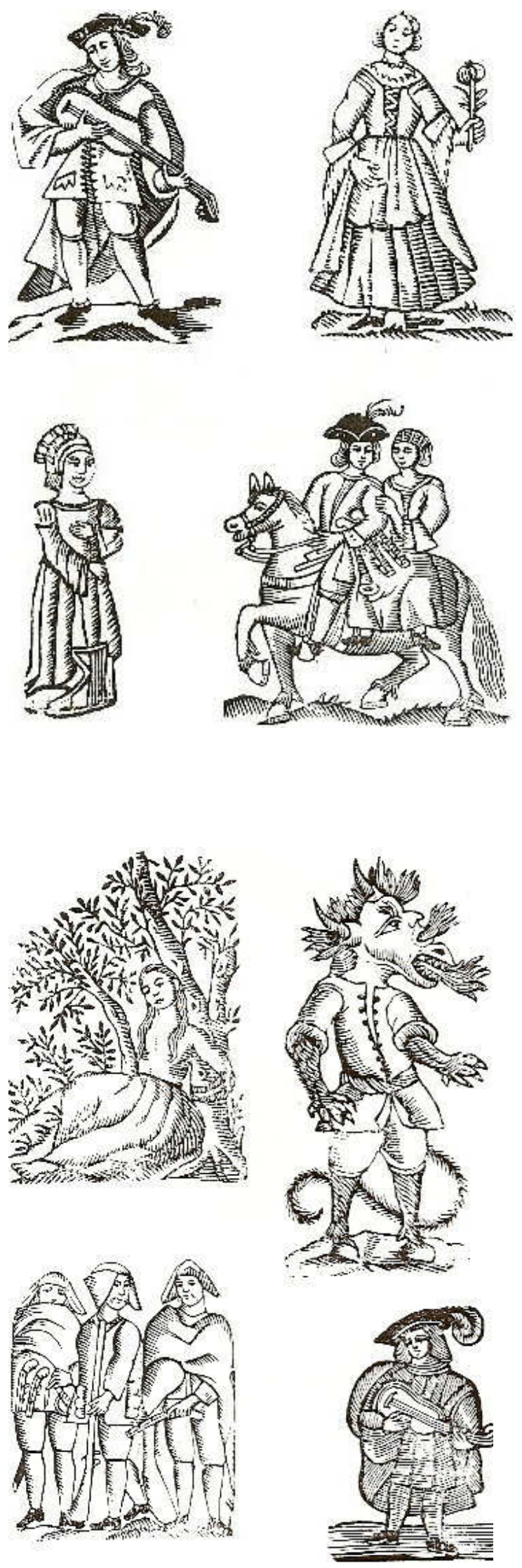

[TORMO, Enric. O cavalo de todas as cores. n. 1, Barcelona, 1959] 


\section{Entrevista com Enric Tormo}

RSC: Como o senhor começou a trabalhar com tipografia?

ET: Minha formação é de tipógrafo. Como eu tinha Belas Artes, depois tipografia, dediquei-me à edição. Então, trabalhava em empresas de edição, em editoras ou colaborando em outras empresas, até que, depois de alguns anos, na Escola de Artes Aplicadas, para toda a coisa do livro. Eu sempre estive dentro do mundo do livro. Em 67, em colaboração com o Museu Tecnológico e o diretor, que era meu amigo, fundamos o Museu do Livro e de Artes Gráficas, que está no Pueblo Español de Montjuïc. Meu mundo foi sempre o livro. Além disso, minha esposa é bibliotecária. Ela era bibliotecária de uma instituição estatal, que tinha uma biblioteca, única na Espanha, dedicada às artes gráficas e ao livro, que claro, me facilitou muita informação do ponto de vista técnico, histórico.

RSC: O senhor tinha experiência com livros antes dessa época?

ET: Sim. Desde o ano 40, 41, já me dediquei a trabalhos de edição como assessor, como responsável de produção, ou seja, toda a mecânica da confecção do livro.

RSC: O senhor se lembra como conheceu Cabral?

ET:Acho que foi através de Brossa, eu diria. Como ele o conheceu, não saberia dizer.

Além disso, meu pai praticava muito a fotografia, então, também recolhi esta parte de documentação gráfica.

RSC: Lembra-se de quando Cabral decidiu ter a prensa, como o ajudou?

ET: Passou-se tantos anos, exatamente não sei. Conhecemo-nos e ele me disse que queria montar uma prensa e se eu podia ajudar. Acompanhei-Ihe, comprou uma Minerva e uma Boston, e uns tipos; pegou o goldoni, que é o tipo mais fácil de trabalhar do ponto de vista estético. E comprou todo um rolding, que tinha os corpos, o 8, o 10, o 12, o 18, eu acho. Comprou as ferramentas, o componedor, a prensa de provas, em um cômodo tinha tudo isto. Fui bastante tempo, periodicamente, quando me necessitava e me chamava: Tormo, será que pode passar pois tenho uns problemas? Eu ia, ajudava-o.

Eu lembro que ele tinha um problema, dor de cabeça sempre, sempre estava com uma aspirina e lhe apertava o nervo, a carótede. E aqui em Barcelona se operou, mas não tirou nada disso. 
RSC: Inclusive, parece que essa atividade de impressão foi uma espécie de terapia...

ET: Sim, para ter uma atividade. Às tardes passava divertindo-se, distraindo-se, seguramente como terapia, porque realmente necessitava. Eu me lembro que estávamos falando, e me dizia: desculpe, um momento, vou tomar uma aspirina.

RSC: Podemos voltar a falar da edição do livro Joan Miró? O senhor conheceu Miró também nesse período?

ET: Conheci Miró através de Brossa. Vou te contar a história. Quando regressamos [de Salamanca], nos liberaram do exército de Franco, e o pai de Brossa era gravador de pranchas de bronze para encadernação, isto que se imprime. Prats você viu os chapéus, na fita, levam uma marca, isso também era uma prancha e a encarregava nessa oficina, onde trabalhava Brossa, porque seu pai era gravador e morreu jovem. Então Brossa foi trabalhar na casa de um amigo que era gravador de bronze e Prats encarregava esse gravador as marcas dos chapéus. Brossa ia levá-los à casa de Prats, e ali iniciou a amizade com Prats. Entre nós falávamos de arte, de Miró. Brossa entrou em relação com Miró através de Prats. Um dia fomos ver Miró uma noite com Prats, e ali estivemos falando de tal material. Tenho uma carta de Miró a Brossa dizendo-Ihe que queria falar comigo. Fui à casa de Miró. Ele havia preparado durante a guerra em Paris uma coleção de litografias desenhadas sobre papel e que tinham que passar à tiragem e trouxe de Paris. Havia que fazer esse trabalho. Eu me encarreguei da impressão dessas litografias que são conhecidas como série Barcelona, de não sei quantas litografias são, 50, não sei quantas. Cuidei da tiragem. Quando Miró começou nesse mundo da gravura, da ilustração, havia um editor suíço, Gerard Cramer, que Ihe propôs fazer uma edição de um livro de Paul Eluard, se chama $A$ toute preuve, acho que é o melhor livro que se fez com gravuras, 300 e tantas de madeiras foram feitas e se imprimiu em Paris. Eu preparei para Miró todas as madeiras, ele gravou-as e colocava as provas na prensa. ĺamos a Paris com as madeiras, levá-las ao impressor que as devia imprimir. Demoramos para fazer esse livro, desde que começou até que apareceu, 8 anos. Miró o fazia quando podia. Esse livro é muito apreciado.

RSC: Cabral já tinha relação de amizade com Miró? O trabalho de edição entre os três foi fácil? 
ET: Sim. Quando fizemos este (Joan Miró, de Cabral, 1950), eu estava trabalhando com o livro de Cramer. O livro de Cabral é a metade do formato do livro de Paul Eluard, é o mesmo papel.

RSC: Trabalharam esse livro de Miró na gráfica que se chama...

ET: Bachs. Mas essa é uma prensa comercial, onde a gente é muito apressada. O livro está composto à mão e em português, esse é o problema. Porque os tipógrafos não estavam habituados em compor em um idioma estrangeiro.

Eu tenho uma boa lembrança dessa colaboração com toda essa gente, como todo esse mundo.

RSC: Poderia contar sobre sua possível ida ao Brasil?

ET:Cabral insistia muito. Dizia: você tem que ir ao Brasil - por essa época, 49, 50 ; se você fosse ao Brasil, seria o pai da tipografia brasileira. Eu disse: não, já tenho bastante em ser pai dos pequenos que temos. Ocorreu essa anedota. Fomos ao cais, paramos à saída do barco e estivemos falando com Matarazzo. Estive falando com minha esposa e desistimos. Essa é uma postura um pouco covarde, francamente, mas quando se tem uma família, um trabalho, ir embora, pegar um barco...

Barcelona, fevereiro de 2005

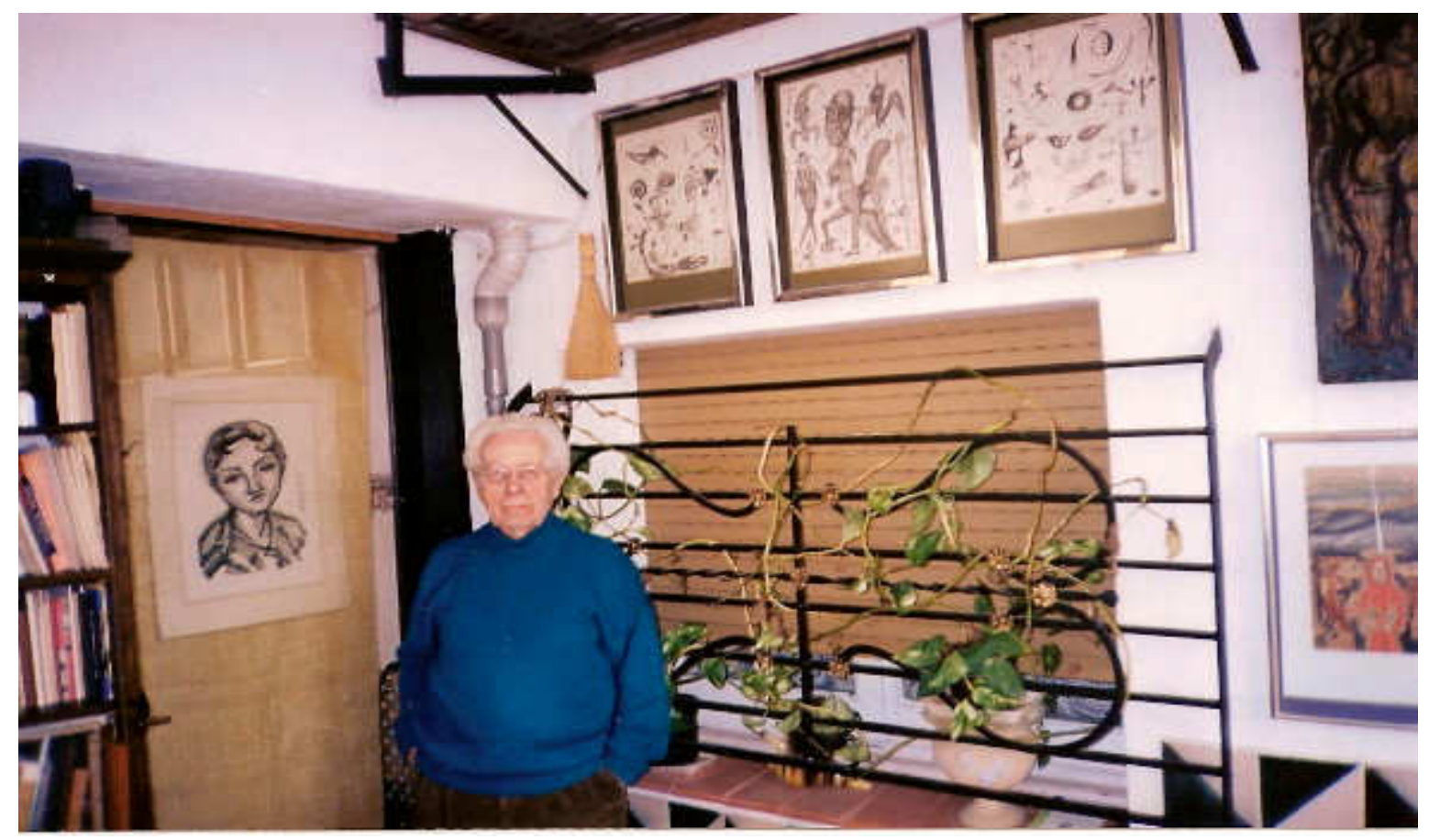




\section{Prólogo a En va fer Joan Brossa}

Este livro de Joan Brossa reúne os primeiros passos do autor no sentido de realizar uma poesia mais amplamente humana. Mais amplamente humana, ou seja: com o grande tema dos homens. E não estritamente humana, com os temas de um homem, individual, embora continuem os temas, do seu refeitório, do seu quarto, dos seus álcools, das suas máquinas de fugir da realidade.

Esta distinção é muito importante. Talvez o problema essencial da arte atual - a procura de um caminho que a leve a uma outra coisa, a procura de uma porta de saída -, a superação do seu formalismo é reduzida a isto: o reencontro dos homens. A coisa primordial não consiste em abandonar a deformação e a estilização nem, simplesmente, em retornar a uma representação clara do objeto. O fato primordial é saber que objeto se vai pintar, que objeto é digno de se pintar. $E$ fazer retornar à arte o tema dos homens.

Aqui há um grande número de artistas irritados contra a falsa profundidade do balbuceio, contra o mundo falso dos surrealismos em que foram encontrar instalada a poesia, e a qual haviam começado a tomar seriamente (é interessante fazer notar a diferença de tom entre um Apollinaire ou um Max Jacob e um jovem poeta de hoje; aquilo que para os primeiros era "humor" para os poetas de hoje se torna solenidade. Os primeiros "fingiram" acreditar, os jovens de hoje acreditam realmente - daí seu tom místico, solene ou desesperado), que lutem hoje para encontrar uma nova forma mais próxima às realidades. Mais, como dizem eles: realista.

A tendência é muito mais generalizada do que nos parece, e esta obesessão se enraíza inclusive em alguns dos que, com mais intensidade - camuflada em desespero - continuamente exercitam-se em todos os truques conhecidos para criar esta falsa dimensão arbitrária de realidade.

Contudo, nem sempre estes jovens artistas situam a questão sob a perspectiva correta. O realismo não é uma questão de forma. É essencialmente uma questão de substância, de assunto. Uma maçã em uma bandeja, pintada com o "trompe-l'oeil", não será realismo no verdadeiro sentido, mas academicismo. Conseguir, outra vez, a cópia exata de um objeto não nos conduz a nenhuma saída definitiva: retornam ao ponto de partida. Vão ser as maçãs pintadas - ou a contínua limitação da realidade naquilo de mais restrito, como esta maçã -, o que vai 
conduzir ao formalismo atual. Da maçã aos simples círculos amarelos e vermelhos de um quadro abstrato, o ponto é mínimo. Vai ser o abandono da dignidade, ou seja, da importância humana (para os homens) dos assuntos, o longo caminho que vai fazer desembocar os artistas em uma arte que nega radicalmente o assunto. De fato, a importância, para os homens, de um quadro com uma bandeja de maçãs e de um quadro com círculos de cor é absolutamente a mesma. Em certo sentido, quando a pintura vai descender até a natureza morta, ao nu, à paisagem de tabique, vai começar a se tornar abstrata.

Perfeitamente consciente de tudo isso, Joan Brossa vai empreender a sua reação para o outro extremo da corda. Ele já havia explorado anteriormente todas as variedades do formalismo e todos os recantos dos gabinetes de magia. Desde o balbuciar minuciosamente orquestrado dos Sonets de Caruixa, até à "ópera de quatro vinténs" de Dragolí, alternados, sempre, com as prosas e o teatro de alucinação sistemática, com os quais procurou a quinta pata do gato e a sétima cara do dado. Ele havia chegado a ser forte nesta retórica, tão forte que, ele mesmo, a havia acrescentado com novos capítulos de sua invenção. Irritado também contra toda esta magia, que chegara a acreditar "mais real que o real", Brossa, contrariamente a muitos destes jovens que se debatem na atual busca da "forma realista", vai seguir o caminho oposto: cantar o "real" com a forma que dispunha.

Ele, apesar de tudo, já parecia conhecer mesmo a força deste "real" e intuía que acabaria, fatalmente, por explorar a sua retórica, eliminando tudo o que há de falso e artificial, e dando novo sentido - saturando de conteúdo - ao que nela pode constituir enriquecimento para o homem na técnica de comunicar-se com os outros homens.

Por que Joan Brossa pôde chegar a isso (conversas com amigos; simples acasos; fastídio, simplesmente) é quase impossível de investigar e definir. No entanto, se observarem tudo aquilo que anteriormente escrevia, esta evolução nos mostra com uma lógica interna evidentíssima. Talvez por que não fosse uma de suas originalidades $\mathrm{o}$ seu repertório, profusamente cotidano e popular? Contrariamente a quase toda a poesia catalã e atual, preocupada sempre pelo vocábulo nobre, pouco corrente, erudito ou arcaico, era na realidade mais humilde, no léxico da cozinha, da feira de praça e do fundo de oficina, onde Brossa ia buscar o material para elaborar as suas complicadas mitologias. Por isso é compreensível 
que, ao pressentir a falsidade de toda a sua temática anterior, se tenha colocado cara a cara com este seu vocabulário concreto e, a partir dele, da realidade da cozinha, da feira e do fundo de oficina, onde o havia recrutado.

A propósito, a realidade da cozinha, da feira e do fundo da oficina não é muito propícia à degustação da natureza morta, ociosa. A maçã existe ali, quando existe, para ser comida, ou para ser disputada. A realidade que Brossa vai descubrir de novo não era o gozo ocioso de um objeto. Aquela realidade estava ritmada por uma luta acesa, na qual nenhum abandono não era possível. Ali o sofrimento não é uma horta para ser cultivada, nem uma coisa para elevar à dignidade, mas, ao contrário, uma coisa que busca ser superada. Esta luta está alerta; é essencialmente viril e, no fundo, já que não se interrompe nem é submetida, otimista.

Este livro reúne os primeiros passos que vai fazer Brossa fora da atmosfera impregnada de magia de cartão postal. A evolução desta nova tendência da sua poesia, cuja tendência assitem o nascimento neste livro, frágil como a fonte de onde brota um rio, haveria de prosseguir posteriormente: prossigue posteriormente. Eu sinto cada dia mais robusta e fortalecida o que aqui é encarado vacilante e somente desponta. Conseqüentemente, o livro ganha um novo interesse psicológico, já que mostra ao claro o processo absolutamente ejemplar seguido por Joan Brossa e que me orgulhece de haver podido acompanhar.

João CABRAL de MELO

[BROSSA, Joan. En va fer Joan Brossa. Barcelona, Cobalto, 1951, p. 9-13. A tradução ao catalão é de Rafael Santos Torroela.] 


\section{Murilo Mendes e João Cabral de Melo Neto}

As "vozes" destes dois poetas, Murilo Mendes e João Cabral de Melo Neto, juntas neste mesmo disco, vão sentir-se muito à vontade. Sendo embora de duas gerações distintas e com certas oposições entre si, são vozes da mesma família poética. Pois os poetas se distribuem, naturalmente, segundo o seu temperamento e o seu estilo, por famílias estéticas diferentes. E estes dois pertencem ao mesmo grupo que podemos chamar dos modernistas "clássicos".

São de gerações distintas: Murilo Mendes, estreante de 1931, pertence ao famoso grupo da segunda geração moderna, que veio trazer a mensagem dos novos em sua plenitude, com Augusto Frederico Schmidt, Carlos Drummond de Andrade e Jorge de Lima, para só falar dos ases dos ases. João Cabral de Melo Neto já pertence à chamada "geração de 45", embora estreasse em 1942 com a sua finíssima flauta da Pedra do sono. Já pertence ao neo-modernismo, portanto.

Ambos, porém, são da mesma família de espíritos, a que chamo de "clássicos", por oposição aos "românticos". Pois classicismo e romantismo não são apenas duas escolas literárias sucessivas. São dois temperamentos estéticos que coexistem nas mesmas escolas. Enquanto um Manuel Bandeira, um Carlos Drummond, um Murilo Mendes, um João Cabral são "clássicos" do modernismo ou do neo-modernismo; - um Augusto Frederico Schmidt, um Jorge de Lima, um Alphonsus de Guimarães Filho, como na primeira haviam sido um Mário de Andrade, um Cassiano Ricardo (que depois evoluiu para o clássico), um Menotti del Picchia, são "românticos" do movimento.

O que encontramos na poesia de Murilo Mendes como na de João Cabral é a mesma sobriedade incisiva, a mesma graça hieroglífica, a mesma concisão cristalina, um senso parecido de "humour", a mesma predominância dos metais sobre as cordas, em oposição ao que encontramos na estilística, mesmo dos mais modernos "românticos". Em ambos a mesma dureza penetrante, que João Cabral exprime tão bem no seu último e admirável poema Uma faca só lâmina, agreste e inesquecível como uma página de Graciliano Ramos e certos poemas da Poesia em pânico de Murilo. Mas entre Murilo e João Cabral há esta outra diferença: naquele a constante presença de Deus, na aridez dos desertos humanos: neste a "ausência", que nem a "bola", nem o "relógio", nem a "faca", os três símbolos de sua poética máscula, ascética e inflexível conseguem substituir. 
Pelas suas afinidades, como pelas suas disparidades, as vozes destes dois grandes poetas, mestres da sutileza, da alusão, dos ritmos curtos e penetrantes, e ambos ultimamente falando igualmente a voz da terra, na Contemplação de Ouro Preto de Murilo Mendes e no Rio de João Cabral (que corresponde, em linguagem brasileira, ao que foi o Vouga do venerável Antonio Correia de Oliveira em Portugal) - são vozes que se unem a uma geração de distância, no mesmo coro cristalino, sutilíssimo e ariélico, que faz da poesia moderna um dos grandes momentos da nossa evolução lírica.

Tristão de Athayde

[Poesias - Murilo Mendes e João Cabral de Melo Neto. LPP 010 - Poesias Festas Discos - Rio de Janeiro. Direção de Irineu Garcia e Carlos Ribeiro. [1956?] 


\section{Epígrafes da $1^{\text {a }}$ edição de Tempo espanhol (1959)}

Mester trago fermoso, no es de juglaria

LIBRO DE ALIXANDRE, ANÓNIMO, SÉC. XIII

Qualquier omne que la oya, si bien trobar supiere

Puede más añadir e enmedar lo que quisiere

ARCIPRESTE DE HITA

Conmigo solo contiendo

En una fuerte contienda,

$Y$ no hallo quién me entienda,

Ni yo tampoco me entiendo

JORGE MANRIQUE

Yo no digo mi canción

Sino a quién conmigo va.

ROMANCE DEL INFANTE ARNALDOS

Que muero porque no muero

SANTA TERESA DE JESÚS

Un poco de luz y no más sangre

CERVANTES

Peñascosa pesadumbre

CERVANTES (SOBRE TOLEDO)

A mis soledades voy,

De mis soledades vengo

LOPE DE VEGA

Las horas que limando están los días,

Los días que royendo están los años

GÓNGORA

Me duele España

MIGUEL DE UNAMUNO 


\section{Nota preliminar a "Poemas de Murilo Mendes"}

Dentro da literatura brasileira não se pode considerar Murilo Mendes (nascido em 1901, publica seu primeiro livro em 1930) fora do fluir ulterior do "modernismo" nome incômodo para nós, porque traz em seguida à mente uma relação, que é falsa, com o "modernismo hispânico": o "modernismo" brasileiro apenas se inaugura, digamos, oficialmente em 1922, embora estivesse em gestação poucos anos antes.

Dentro da literatura mundial, Murilo Mendes há de inscrever-se nesse grande movimento que descobre o valor poético do subconsciente, dos sonhos e dos impulsos primários, representados antes de tudo pelo "surréalisme" francês, mas do qual se podem encontrar também, espalhadas por várias literaturas, muitas raízes, umas vezes imediatamente anteriores, outras profundas no tempo.

Não é Murilo Mendes um "seguidor" de uma moda: nele, provavelmente, não se teria produzido o poeta com seu rico conteúdo sem a coincidência de sua vida com esse momento em que se rompe o dique represado do homem mais interno, do homem mais subterrâneo, e em que ao encadeamento lógico pode substituir a inconexa variedade dos fragmentados materiais da explosão. Está claro que, nem em Murilo Mendes, o poema pode ser uma mera acumulação de detritus e raízes: há precisamente em sua poesia uma oscilação entre elementos conceituais ligados por lógica e elementos puramente imaginativos: há até algum livro que se inclina em direção ao primeiro: assim no momento do encontro de Murilo com o catolicismo, quando, em colaboração com Jorge de Lima, publica Tempo e eternidade, 1935. A maioria de sua obra, no entanto, fixa-se no segundo. Seria bem compreensivo, inclusive nos casos que parecen mais extravagantes, pensar em uma simples amontuação: esse suceder-se de imagens desligadas tem seu sentido profundo; é uma espécie de callida junctura, se bem muito diferente da de Horacio; os fragmentos que parecem inconexos se associam para produzir a intuição total do poema na mente do leitor. Isto se faz, além disso, dentro do rompimento total das normas da composição poemática e inclusive - salvo em algum livro - do ritmo (e não há que mencionar sequer a rima).

Nestas notas Murilo se parece a outros poetas de seu momento. Retomo agora meu tema anterior. Cada poeta tem seu momento exato para nascer. Murilo pôde ganhar estatura de grande poeta pelo fato providencial de sua coincidência humana com essa época de explosão do represado. Assim, o que se derramou em 
abundância na produção poética de Murilo Mendes forma uma enorme vazão significativa. Falando João Cabral de Melo da poesia de Murilo Mendes, diz: "Ela foi, sobretudo, a que me ensinou a dar precedência da imagem sobre a mensagem, do plástico sobre o discursivo." Essa precedência é muito certa em Murilo Mendes e confirma o que antes eu disse. Mas acredito ser necessário acrescentar que da poesia de Murilo Mendes sai outro tipo de transcendental "mensagem". Dessa enorme acumulação de materiais imaginativos (expressiva, como vimos, por si mesma) sai uma poderosa violência para as mentes e os corações. Poucos livros de poesia contemporânea movimentam tão completamente o leitor, como este tomo de Poesias 1925-1955, de Murilo Mendes: na relação do homem com sua origem, na relação individual com a vida, na relação social. Poucos livros poderão contribuir mais à construção de uma humanidade melhor, de um mundo melhor.

Há muita tradição oculta sempre em qualquer técnica revolucionária. Porque o poeta expressa, juntando-os, o significado dos tempos antigos, do que ele realiza no presente e do futuro que adivinha. Em ninguém melhor do que em Murilo Mendes se dá esta equivalência de distâncias. Acredito que em sua própria poesia se realiza de modo evidente o que ele diz falando do "poeta futuro":

O poeta futuro já se encontra no meio de vós.

Ele nasceu da terra

Preparada por gerações de sensuais e de místicos:

Surgiu do universo em crise, do massacre entre irmãos,

Encerrando no espírito épocas superostas.

O homem sereno, a síntese de todas as raças, o portador da vida

Sai de tanta luta e negação, e do sangue espremido.

O poeta futuro já vive no meio de vós ${ }^{395}$

[ALONSO, Dámaso. Revista de Cultura Brasileña. a. 1, n. 1, Madri, jun. 1962, p. 79]

395 "O poeta futuro" In As metamorfoses (PCP, 319) 


\section{Enquete sobre a literatura brasileira de vanguarda}

Roma, 23 de julho de 1964.

Queridos Ángel Crespo e Pilar Gómez Bedate:

Infelizmente não disponho de tempo para responder longamente, como desejaria, à enquete sobre a literatura de vanguarda no Brasil, para a excelente revista que publicam em Madri.

No entanto, não querendo deixar sem resposta o interessante questionário, resumo aqui, em duas palavras, o que penso a respeito do assunto.

Todas as formas e expressões de literatura de vanguarda devem ser estimuladas e reconhecidas. Em nossa época, no Brasil, a literatura de vanguarda começa em 1922. Deu obras importantíssimas, e mais que tudo, deu o grande impulso em direção à renovação da literatura brasileira. Desde 1922 até hoje assistimos a magníficas manifestações da vanguarda literária. Nos últimos anos, a poesia concreta, a poesia-práxis, tem apresentado, tanto na parte teórica, quanto na parte prática, documentos de primeira ordem.

Em nossa época, a vanguarda constitui já uma tradição. Além disso, nunca se é suficientemente vanguardista. Não oponho a vanguarda à tradição; oponho-a, isso sim, ao academicismo.

Nosso tempo - afortunadamente - é um tempo de transformações constantes, diárias. A literatura não é, sem dúvida, a ciência, mas deve refletir também as formidáveis mutações da ciência. $O$ que acima de tudo caracteriza o espírito de nossa época é a vanguarda em tantos e tão variados setores. A literatura de vanguarda no Brasil tem que procurar corresponder, no plano estético e de pesquisa de uma nova dimensão da palavra, a alguns dos anseios mais válidos e autênticos do homem de hoje.

M.M.

[Revista de cultura brasileña. Número extraordinario sobre literatura de vanguardia. Tomo 3, n. 11, Madri, dez. 1964, p. 356-357] 


\section{Nota aos Poemas inéditos de Murilo Mendes}

O último livro de Murilo Mendes, Tempo espanhol, apareceu em Lisboa em 1959. Na mesma cidade, publicou o escritor sua Antologia Poética, em 1964. Mas desde o ano citado primeiramente, Mendes não havia dado a conhecer nenhuma mostra de sua mais recente ocupação poética. Agora, com a publicação destes sete poemas inéditos, escritos entre 1959 e 1963, o autor de Contemplação de Ouro Preto nos oferece a ocasião de tomar conhecimento de suas últimas preocupações temáticas e estilísticas.

O contato com a realidade espanhola, que tanto influiu em seu compatriota João Cabral, parece ter atuado em análogo sentido em relação ao grande poeta mineiro: um desejo de concreção, de sobriedade expressiva, de plasticidade não isenta de inquietudes metafísicas, se descobre nestes inéditos de Murilo Mendes. Tanto $\mathrm{o}$ ar surrealista de seus primeiros livros quanto o barroquismo dos versos em que cantou a antiga capital de Minas Gerais, cedem, agora, diante da sobriedade expressiva e o rigor da construção; uma construção que quer (e consegue) ser nova, não por um mero desejo de originalidade, mas pelo que não se pode verter um pensamento original em um forma que não o seja. A fronteira entre a prosa e 0 verso, segundo os conceitos tradicionais, é aqui bastante imprecisa. A busca de uma expressão "totalmente poética" parece prescindir do quanto possa lembrar a preconceito.

Estes Murilogramas, este Grafito e outros poemas que Murilo Mendes publica aqui revelam também sua longa permanência na Itália e sua participação na vida literária e artística italiana. Ainda permanecem vestígios no léxico (ahimè, tessera, baleno, barlume) ou na formação de palavras (-ésimo) destas obras. Está claro que em nossa tradução respeitamos essas vozes italianas. ${ }^{396}$

Excetuando o "Murilograma à Filha de Miguel Torga" - o conhecido poeta contemporâneo português - e o "Natal 1961" todas as outras poesias têm tema italiano, da literatura (Cavalcanti) ou da pintura (Capogrossi, Carla Accardi) ou da arquitetura (Borromini) ou da música (Monteverdi). Neste último poema é onde o poeta parece entregar-se a certo automatismo expressivo, mais de forma que de fundo. Mas é que ainda os versos dedicados à filha de Torga têm, incrustadas de

\footnotetext{
${ }^{396}$ Nota dos autores: Tampouco ressaltamos tipograficamente estas vozes italianas, tendo em vista que o autor não o faz no original.
} 
propósito, algumas vozes italianas. Por quais estranhas vias iria a dar don Luis de Góngora com o distante Guido Cavalcanti, e inclui-lo nos "estrangeiros, dulcíssimos poetas"? Dante, que foi seu amigo (Guido, vorrei que tu e Lapo ed io...) e Ihe sobreviveu uns quinze anos, recorda-o nessa passagem do Purgatorio citado por Murilo Mendes (são palavras em boca de Oderisi: “l'altro Guido" é Guinicelli, poeta um pouco anterior a Cavalcanti). Os quatro últimos versos do Murilograma são do próprio Cavalcanti e pertencem a um soneto que, por sua grande beleza, não nos resistimos a transcrever:

Tu m'hai si piena di dolor la mente che l'anima si briga di partire; e li sospir che manda il cor dolente, mostrano a li occhi che non pon soffrire. Amor, che lo tu'grande valor sente, dice:- Mi duol che ti convien morire per questa fera donna, che neente par che pietate di te voglia udire.

lo vo come colui ch'è fuor di vita, che pare, a chi lo sguarda, ched el sai fatto di rame o di pietra o di legno, che sé conduca sol per maestria, e porte ne lo core una ferita che sai, com'egli è morto, aperto segno.

Todos estes poemas, entre os quais certamente sobressai Murilograma à Filha de Miguel Torga, mostram a recente evolução do poeta em direção a uma condensação de palavra e de pensamento: os problemas filosóficos ("Que é um ser?") tomam agora uma posição central em sua poesia. A expressão pode alcançar intensa concentração:

O pintor constrói o signo

O signo mede o pintor 
Fundo e forma caminham em direção a uma síntese reveladora da constante capacidade de Murilo Mendes para tomar o pulso a sua época e nos oferecê-la transcendida em exemplos da melhor poesia.

[ALONSO, Damaso e CRESPO, Ángel. Revista de cultura brasileña. n. 12, Madri, março 1965, p. 5-7] 


\section{Nota bibliográfica}

MENDES, Murilo: Italianíssima, 7 Murilogrammi. Strenna per gli Amici, Milano, MCMLXV, 26 págs. Com uma ilustração de Lucio Fontana.

Nossa revista foi a primeira em publicar as composições que o poeta mineiro Murilo Mendes batizou com o título de murilogramas. Dos sete que compõe este breve livro, dois deles - os dedicados a Guido Cavalcanti e a Claudio Monteverdi se contam entre as composições inéditas que oferecemos a nossos leitores, juntamente com outras, que por não estarem dedicadas a temas italianos ou por não serem murilogramas, não fazem parte da curta coleção que queremos comentar. Esta, por sua vez, é parte do livro inédito Contacto, cuja aparição há de surtir, sem dúvida, benéficos efeitos sobre a nova poesia do Brasil. Afirmamos isto porque estamos seguros de que a intensa corrente humanista que alimenta a este livro - a julgar pelas mostras que dele conhecemos - há de fecundar e esclarecer os propósitos da mais avançada poesia brasileira contemporânea.

Nós que viemos seguindo, passo a passo, o desenvolvimento poético do Brasil, e admirando sua fecundidade formal e sua rica veia temática, temos a impressão de estar assistindo à fundação de um novo humanismo capaz das mais arriscadas sínteses. A atual poesia brasileira, sem renegar suas origens peninsulares nem sua longa aprendizagem ocidentalista, tem sabido incorporar-se (na medida do possível sem violências desnaturalizadoras), além das conquistas de um americanismo lúcido e de cara ao futuro, aspectos fundamentais da melhor poesia oriental, tudo isso através de sínteses originais e abertas, ou seja, absolutamente antidogmáticas, embora o calor de algumas polêmicas possa fazer, por enquanto, que pensemos o contrário. Imaginemos o que será para esta nova poesia a incorporação, através da última obra de Murilo Mendes, da mais viva tradição italiana, vigorada - mediante uma inteligentíssima compreensão - pelo gênio do extraordinário poeta mineiro.

A opção do escritor que vive durante longos anos fora de sua terra costuma ser a saudade, se não acabar aquele por integrar-se, nunca completamente, na cultura do país que reside, esquecendo, ou deixando longe, as origens geográficas de sua própria obra. Não é este o caso de Murilo Mendes, quem, se por um lado 
cedeu ao atrativo da impressionante cultura italiana, soube por outro unir suas experiências com as preocupações das letras de seu país.

A montagem de seus poemas italianos refletem uma profunda preocupação por evitar a discursividade, por conter qualquer desbordamento em benefício da expressão ajustada, sóbria, mas, ao mesmo tempo, sugestiva ou, melhor dizendo, capaz de profundas e prolongadas ressonâncias. Assim, estes poemas são faces de lâminas móveis - não saberíamos definí-los de outra maneira - cujas vibrações, à medida que vamos tocando-as uma a uma, acabam por confundir-se harmonicamente. Isto quer dizer que semelhantes poemas participam de valores ideográficos e musicais e apontam em direção a soluções que vem preocupando aos poetas mais conscientes do Brasil.

Em que medida / Leopardi
Será tua linguagem
Tangente à - rompida - nossa?

Não fui a Recanati: vou aos CANTI.

Assim começa um dos murilogramas, expressando a preocupação por fazer nossas as palavras dos grandes poetas italianos. E Mendes termina - no belíssimo poema a Cavalcanti - por incorporar-se as próprias palavras do italiano:

\section{Explicas a automização:}

IO VO COME COULI CH'É FUOR DI VITA, CHE PARE, A CHI LO SGUARDA, COME SAI FATTO DI RAME O DI PIETRA O DI LEGNO,

\section{CHE SÉ / CONDUCA SOL PER MAÏSTRIA,}

intervindo, inclusive, no texto de Guido com um signo de pontuação (/) que sublinha a intenção da citação.

Valham estas duas mostras para dar uma idéia da riqueza de procedimentos da recente poesia de Murilo Mendes; nova, ademais, porque a matéria poética, que em outros livros deste autor permanecia em certo estado de fluidez, se ordena nela 
de acordo com canônes abertos - no sentido em que é aberto um ideograma - , sem abandonar, graças ao profundo impulso musical que a conforma, um tom melancólico muito ocidental e, por conseqüência, muito brasileiro.

Esperemos que a aparição de Contacto nos permita calibrar o alcance da mensagem que Murilo Mendes há de dirigir, através da brasileira, a toda a poesia de nosso tempo.

[CRESPO, Ángel. Revista de Cultura Brasileña. n. 16, Madri, mar. 1966, p. 95-97] 


\section{Jorge Guillén}

-Segundo Aubrey F. G. Bell, solidez, equilíbrio, concentração, intensidade, humour são as qualidades castelhanas por excelência. Creio que elas se encarnam de modo exemplar na obra e na pessoa de Jorge Guillén. Sua preocupação de limpidez e artesanato rigoroso ligam-no a Paul Valéry, de cuja linha estética ele partiu.

-Seria hoje acadêmico escrever que J. G. domina a linguagem. Qualquer poeta autêntico deve dominar a linguagem, do contrário não poderia fazer poesia. Menciono este truísmo porque foi, entre os anos 1940-50 usado e abusado por vários críticos, particularmente no Brasil: e nem todos eram ingênuos, muito pelo contrário. Voltava então à cena o conhecido diálogo Mallarmé-Degas. Ora, Mallarmé advertira um pintor, nenhum poeta precisaria de tal conselho.

-J. G. espanholizou, transformou e alargou o projeto da arquitetura valéryana; sendo a dimensão da sua poesia única, pessoal, intransferível. Consideramos um poeta que usa com atenta disciplina, liberdade, fantasia, ao mesmo tempo metros tradicionais e metros livres; curtos ou largos; que nunca chega mesmo à ruptura da linguagem, porque se propõe sempre a arquitetura do poema. Espírito dialético por inclinação e cultura, diria que reúne pontos inconciliáveis: subjetividade e objetividade, abstrato e concreto, imanência e transcendência. Numerosos exemplos se encontram ao longo de sua obra, que poderia trazer como epígrafe este verso: "Alma, fiel a un volumen".

-J. G., diurno (provém da luz castelhana, luz de personalidade forte, diria até intelectual) exorciza os espantalhos da noite, aceitando "sus potencias breves/ bajo un sigilo sin horror ni enigma." Num tempo dilacerado como o nosso, tempo de negação da vida, do próprio homem (não me refiro à negação de Deus, pois todas as outras negações são conseqüências desta), torna-se milagrosa a figura de um poeta que adere ao mundo ("porque es mi sino/ propender con fervor al universo"); que sofre até osso com a desordem ("oh torpe caos!"), que erige a exatidão em divindade, encontrando palavras definitivas para seu desafio castelhano-planetário 
à fatalidade das "postrimerias", presentes todo o dia ao espanhol: "Por mí no mi moriré. Me morirán".

-Acenando no início ao vínculo estético Guillén-Valéry, fi-lo em situação à crítica que geralmente o define. Mas, diante de um poeta desta altura, é claro que não se deve tratar de univocidade. No prefácio à Selección de poemas, publicado na Espanha em 1965, J. G. informa-nos que foi desde muito jovem atraído pela construção rigorosa de Les fleurs du mal; seguindo-se mais tarde a descoberta de Leaves of grass. Indicações certamente preciosas; mas não me sirvo delas para fixar limites a uma obra que caminha no tempo sob signos diversos, inclusive os de Dante e Mallarmé.

- Num ensaio dos anos 50 Dámaso Alonso explica J. G. em contraposição a certa linha crítica unilateral, atenta apenas ao plano intelectualístico desta obra, que entretanto surge muitas vezes das sensações e dos impulsos mais elementares do humaníssimo "quase animalíssimo" Jorge Guillén. ${ }^{397}$

- Cántico, desenvolvido e reelaborado durante quase 50 anos; Maremágnum, precedido de Clamor, e Homenaje, constituem o vasto tríptico guilleniano, completado por ensaios de problemática da linguagem e da criação literária, de que se destaca Lenguaje y poesía: ensaios fundados, com licença de Gracián, em agudeza-engenho. Os textos de Guillén são férteis em pontos de exclamação e de interrogação, o que poderá afastar certos leitores exigentes. Mas o poeta não usa à maneira dos românticos estes sinais de pontuação. Fazem parte do texto, achamse inseridos nele, direi: correspondem a uma palavra, talvez a uma série de palavras, talvez a uma metáfora. Guillén geometriza a capacidade de entusiasmo do espanhol, organizando o que eu chamaria a praxis do lirismo. Sob o ponto de vista da comunicabilidade penso que a obra de J. G. abarca um raio de ação muito mais vasto que o de Valéry, se bem talvez não contenha um "pezzo" antológico da tessitura de "Le cimetière marin". O citado Dámaso Alonso escreve: "Jorge Guillén es, entre todos los poetas hoy vivos, el de mayor contenido de pensamiento, aquel

\footnotetext{
${ }^{397}$ Nota do editor: Trata-se do ensaio "Los impulsos elementales en la poesía de Jorge Guillén", incluído no livro Poetas españoles contemporáneos, que integra a biblioteca do poeta. O trecho mencionado, à página 242, recebeu um traço à margem.
} 
cuya imagen del mundo es más nítida em su poderosa unidad, com infinita variedad em el pormenor."

-A obra de J. G. constitui um dos monumentos da poesia espanhola, e não só deste século. Como já se escreveu que na Espanha o maior monumento é o homem, terminarei dizendo uma palavra sobre o homem Guillén. Ele é alto, muito magro, moreno, espanholíssimo, olhos pequenos, pesquisadores; delicado e dinâmico. A "signorilitá" é uma de suas características mais fortes. Esgrime a palavra com rigor mordente. Homem-texto, "ragiona", entre lucidez e ironia, de fatos, pessoas, coisas; passa com agilidade do plano estético para o cotidiano impregnado de um fervor cortês. Até seus óculos são personalíssimos. É tocado pelo prazer de respirar. De total simplicidade, sabe ouvir e dialogar como poucos.

• Há muitos anos que o pratico. Encontramo-nos várias vezes, em Roma, Florença, Lisboa e Algarve. Uma das nossas últimas "citas" foi no Jardim Botânico de Lisboa, sítio remansoso no centro da cidade, dando-nos a ilusão de que a natureza ainda existe. Falamos de literatura, da crise universal, "una crisis/ que não se acaba nunca,/ esa contradicción que no nos deja/ vivir nuestro destino", em particular a crise de Portugal e da recíproca Espanha, "esa incógnita España no más fácil de mantener en pie/ que el resto del planeta." O poeta anima-se, e de repente, abrangendo com o olhar agudíssimo talvez a totalidade das árvores, exclama: "Quiero vivir!" oferece-me mais um de seus livros; uma vez eu lhe disse que o texto das suas dedicatórias me fará passar à posteridade. Findo o encontro, no instante da despedida ele comenta: "Caso raro, estivemos juntos duas horas sem comer, nem beber." Regressa ao hotel, para prosseguir a leitura de Os Maias.

Murilo Mendes.

1969-1974.

R.R. $-2^{a}$ série

(Retratos-relâmpo)

[Manuscrito em 5 folhas - Arquivo Jorge Guillén - Biblioteca Nacional - Madri] 


\section{Correspondência de Cabral e Murilo com escritores espanhóis}

João Cabral de Melo Neto - Joan Brossa (Fundación Joan Brossa Barcelona)

1.Carta de Londres, 8 de janeiro de 1951.

2.Carta de Londres, 6 de maio de 1951.

João Cabral de Melo Neto - Gabino-Alejandro Carriedo (Arquivo GabinoAlejandro Carriedo - Fundación Jorge Guillén - Valladolid)

1.Carta de 9 de junho de 1966.

2.Carta de Berna, 26 de agosto de 1966.

3.Carta de Berna, 9 de dezembro de 1966.

João Cabral de Melo Neto - Rafael Santos Torroella (Arquivo Rafael Santos Torroella)

1.Carta de Barcelona, 31 de outubro de 1950.

2.Carta de Barcelona, 7 de novembro de 1950.

3.Carta sem cabeçário (papel impresso do Consulado de Londres e envelope com carimbo de 30 de novembro de 1950).

4.Carta de Londres, 7 de dezembro de 1950.

5.Carta sem cabeçário (envelope com carimbo de 24 de janeiro de 1951).

6.Carta de Londres, 29 de maio de 1951.

7.Carta de 12 de junho de 1951.

8.Carta de Londres, 20 de agosto de 1951.

9.Carta do Rio de Janeiro, 8 de novembro de 1955.

10.Carta de Sevilha, 16 de maio de 1956.

11.Carta de Sevilha, 10 de agosto de 1956.

12. Carta de 28 de janeiro de 1957.

13.Carta de Sevilha, 19 de fevereiro de 1957.

14.Carta de Sevilha, 26 de abril de 1957.

15.Carta de Sevilha, 19 de maio de 1957.

16.Carta de Marselha, 11 de novembro de 1958.

17. Carta de Monte Carlo, 18 de janeiro de 1959.

18.Carta de Marselha, 3 de fevereiro de 1959. 
19.Carta de Marselha, 5 de fevereiro de 1959.

20.Carta de Marselha, 23 de fevereiro de 1959.

21.Carta de Marselha, 13 de março de 1959.

22.Carta de Madrid, 25 de junho de 1962 (a Maite e Rafael Santos Torroella).

23.Carta de Berna, 16 de outubro de 1966.

24.Carta sem cabeçário (papel impresso do Consulado do Brasil).

25.Carta sem cabeçário (papel impresso do Consulado de Londres).

\section{Murilo Mendes - Ángel Crespo (Arquivo Ángel Crespo)}

1.Carta de Roma, 14 de julho de 1968.

2.Carta de Roma, 5 de julho de 1970.

Murilo Mendes - Dámaso Alonso (Arquivo Dámaso Alonso - Real Academia Española - Madri)

1.Carta de Roma, 19 de março de 1959.

2.Carta de Roma, 21 de abril de 1959.

3.Carta de Madri, 16 de setembro de 1959.

4.Cartão postal de Florença, 14 de abril de 1961 (a Damaso Alonso e Eulalia Alonso).

5.Cartão postal de Madri, 24 de julho de 1961 (a Damaso Alonso e Eulalia Alonso).

6.Carta de Roma, 10 de fevereiro de 1962 (a Eulalia Alonso).

7.Carta de Roma, 3 de novembro de 1963 (a Damaso Alonso e Eulalia Alonso).

8.Cartão postal do Museu do Prado, 30 de setembro de 1965 (a Damaso Alonso e Eulalia Alonso).

9.Cartão postal de Roma, novembro de 1966.

10.Carta de Roma, de 14 de setembro de 1968.

11.Carta de Roma, de 19 de dezembro de 1969.

\section{Murilo Mendes - Gabino-Alejandro Carriedo (Arquivo Gabino-Alejandro} Carriedo - Fundación Jorge Guillén - Valladolid)

1.Carta de Roma, 10 de julho de 1964.

2.Carta de Roma, 28 de maio de 1967.

3.Postal de Roma, dezembro de 1968.

4.Carta de Roma, 3 de abril de 1969. 
5.Carta de Roma, 22 de junho de 1969.

6.Carta de Roma, 10 de julho de 1969.

7.Carta de Montedor (Minho), 27 de agosto de 1969.

8.Carta de 5 de agosto de 1970.

9.Carta de Roma, 22 de fevereiro de 1971.

10. Carta de Roma, 15 de março de 1971.

11.Carta de Roma, 17 de outubro de 1971.

12. Cartão de Roma, 1974.

\section{Murilo Mendes - Jorge Guillén (Arquivo Jorge Guillén - Biblioteca Nacional - Madri)}

1.Carta de Roma, 2 de março de 1959.

2.Carta de Roma, 27 de outubro de 1959.

3.Carta de Roma, 10 de janeiro de 1960.

4.Cartão postal de Valladolid, setembro de 1960.

5.Cartão postal de Roma, 28 de dezembro de 1960.

6.Cartão postal de Roma, 26 de fevereiro de 1961.

7. Carta de Roma, 30 de abril de 1961.

8. Carta de Roma, 19 de maio de 1961 (a Jorge Guillén e Irene Guillén).

9. Carta de Roma, 2 de abril de 1962.

10.Carta de Roma, 16 de maio de 1962 (em espanhol).

11.Carta de Monte Gordo, 26 de julho de 1962 (em francês).

12. Carta de Lisboa, 3 de agosto de 1962 (em francês a Jorge Guillén e Irene Guillén).

13. Carta de Lisboa, 5 de agosto de 1962 (a Jorge Guillén e Irene Guillén).

14. Carta de Lisboa, 7 de agosto de 1962 (em espanhol a Jorge Guillén e Irene Guillén).

15. Cartão postal do Porto, 22 de agosto de 1962 (em espanhol).

16. Carta de Roma, 5 de novembro de 1962.

17. Cartão de aniversário de Roma, 18 de janeiro de 1963.

18. Carta de Roma, 14 de fevereiro de 1963.

19. Cartão postal de Roma, 28 de fevereiro de 1963.

21. Cartão postal de Roma, 19 de março de 1964 (a Jorge Guillén e Irene Guillén).

22. Carta de Roma, 6 de julho de 1964: Comentário da leitura da obra de Guillén. 
23. Cartão de Roma, 1967 (a Jorge Guillén e Irene Guillén).

24. Carta de Roma, 6 de fevereiro de 1967 (em espanhol).

25. Carta de Roma, 4 de março de 1967 (em italiano, espanhol, francês e português).

26. Cartão postal de Nova lorque, 3 de setembro de 1967 (em italiano a Jorge Guillén e Irene Guillén).

27. Cartão postal de Roma, dezembro de 1968 (a Jorge Guillén e Irene Guillén).

28. Carta de Roma, 20 de março de 1969 (em espanhol).

29. Carta de Roma, 22 de janeiro de 1970 (em português, francês, italiano e espanhol).

30. Carta de Roma, 1 de janeiro de 1971 (em espanhol, italiano, francês e português).

31. Carta de Roma, 11 de janeiro de 1972 (em italiano).

32. Carta de Roma, 12 de maio de 1973 (em italiano, francês, espanhol e português).

33. Cartão postal de Roma, 11 de dezembro de 1973 (em italiano a Jorge Guillén e Irene Guillén).

34. Carta de Roma, 20 de outubro de 1974 (em italiano).

\section{Murilo Mendes - Rafael Santos Torroela (Arquivo Rafael Santos Torroella)}

1.Carta de Madri, 31 de maio de 1953.

2.Carta de Madri, 24 de setembro de 1959 (a Maite e Rafael Santos Torroella).

3.Carta de Roma, 3 de janeiro de 1960.

4.Carta de Roma, 23 de fevereiro de 1960.

5.Carta de Roma, 8 de março de 1960 (a Maite e Rafael Santos Torroella).

6.Carta de Roma, 2 de julho de 1960 (a Maite e Rafael Santos Torroella).

7.Carta de Roma, 9 de novembro de 1960.

8.Cartão postal de Roma, janeiro de 1961.

9.Carta de Roma, 15 de fevereiro de 1961 (a Maite e Rafael Santos Torroella).

10.Cartão postal de Gerona, 24 de setembro de 1962.

11.Cartão postal de Florença, 28 de setembro de 1962.

12.Carta de Roma, 13 de abril de 1963.

13.Carta de Roma, 27 de junho de 1965.

14.Carta de Madri, 30 de setembro de 1965 (a Maite e Rafael Santos Torroella). 
15.Carta de Roma, 23 de dezembro de 1965 (a Maite e Rafael Santos Torroella).

16.Carta de Roma, 15 de outubro de 1966 (a Maite Santos Torroella).

17.Cartão postal de Roma, 29 de setembro de 1967 (a Maite Santos Torroella e também escrito por Saudade Cortesão).

18.Cartão postal de Barcelona, 2 de agosto de 1968 (a Maite e Rafael Santos Torroella).

19.Cartão postal de Roma, dezembro de 1968.

20.Carta de Roma, 22 de junho de 1969 (a Maite e Rafael Santos Torroella).

21.Carta de Roma, 10 de julho de 1969 (a Maite e Rafael Santos Torroella).

22.Carta de Roma, 2 de janeiro de 1970 (a Maite e Rafael Santos Torroella).

23.Carta de Roma, 19 de maio de 1971 (a Maite e Rafael Santos Torroella).

24.Carta de Roma, 22 de junho de 1971 (a Maite e Rafael Santos Torroella).

Murilo Mendes- Rafael Alberti (Fundación Rafael Alberti - Puerto de Santa María- Cadiz)

- Carta de Roma, 26 de fevereiro de 1968.

Rafael Alberti - Murilo Mendes (ALÇADA, João Nuno. Entre Poetas e Pintores: Murilo Mendes e os seus Amigos Europeus. Separata dos Arquivos do Centro Cultural Caluste Gulbenkian. v. XXXVIII. Lisboa-Paris, Fundação Caluste Gulbenkian, 1999, p. 502-503)

- Carta de Antibes, França, de 16 de fevereiro de 1968. 


\section{Dedicatórias autógrafas em livros}

1941

1. "A Murillo (sic) Mendes, cordialmente José Bergamín. México. Nov. 1941" (Disparadero español. $3^{\mathrm{a}}$ ed. México: Editorial Seneca, 1940 - Centro de Estudos Murilo Mendes - Juiz de Fora)

2. "Al poeta Murillo Mendes muy amistosamente José Bergamín México Nov. 1941" (El pozo de angusia. México: Editorial Seneca, 1941 - Centro de Estudos Murilo Mendes - Juiz de Fora)

1942

3. "A Murilo Mendes, com admiração e amizade. João Cabral de Melo Neto. Re. 7. 1942" (Pedra do sono. Recife: Oficinas Gráficas de Drechsler \& Cia.,1942. Edição do autor - Centro de Estudos Murilo Mendes - Juiz de Fora)

1947

4."A Garcia Vilella, cordialmente, 27.X.47 João Cabral de Melo Neto." (O engenheiro. Rio de Janeiro: Amigos da Poesia, 1945 - Acervo Francisco García Vilella)

\section{8}

5."A Garcia Villela, para desaprender português, João Cabral de Melo Barcelona, 1948." (Psicologia da composição com a Fábula de Anfion e Antíode. Barcelona: O Livro Inconsútil, 1947 - Acervo Francisco García Vilella)

6."A Carles Riba, homenagem de admiração de João Cabral de Melo Neto Barcelona, 1948." (Psicologia da composição com a Fábula de Anfion e Antíode. Barcelona: O Livro Inconsútil, 1947 - Biblioteca de Catalunya - Barcelona)

7. "A Jorge Guillén, homenagem de João Cabral de Melo Neto Barcelona, 14.VIII.948" (Psicologia da composição com a Fábula de Anfion e Antíode. Barcelona: O Livro Inconsútil, 1947 - Biblioteca Pública de Valladolid)

8."A Enric Tormo, Maestro, este primeira incursão a seus domínios, J. Cabral de Melo Barcelona, 23. XI. 48" (Psicologia da composição com a Fábula de Anfion e Antíode .Barcelona: O Livro Inconsútil, 1947 - Biblioteca particular de Enric Tormo) 
9. "A Enric Tormo, fraternalmente, João Cabral de Melo Neto De sua Barcelona, 23.XI.948" (O engenheiro. Rio de Janeiro: Amigos da Poesia, 1945 - Biblioteca particular de Enric Tormo)

\section{9}

10."A Rafael Santos Torroella, poeta e amigo João Cabral de Melo Neto Barcelona, outubro, 1949" (O engenheiro. Rio de Janeiro: Amigos da Poesia, 1945 Biblioteca particular de Rafael Santos Torroella)

11."A Santos Torroella lembrança da tarde de 8.10.949 João Cabral de Melo Neto Barcelona" (Psicologia da composição com a Fábula de Anfion e Antíode. Barcelona: O Livro Inconsútil, 1947 - Biblioteca particular de Rafael Santos Torroella)

1950

12."Ao Garcia Vilella, lembrança de João Cabral de Melo Neto Barcelona, VIII 1950" (O cão sem plumas. Barcelona: O Livro Inconsútil, 1950 - Acervo Francisco García Vilella)

13."A Joan Brossa, fraternalmente, João Cabral de Melo Neto Barcelona, 16. 8. 950" (O cão sem plumas. Barcelona: O Livro Inconsútil, 1950 - Fundación Vila Casals - Barcelona)

14. "Ao Tormo, com um abraço afetuoso do Cabral Barcelona, VIII-950" (O cão sem plumas. Barcelona: O Livro Inconsútil, 1950 - Biblioteca particular de Enric Tormo)

\section{3}

15. "Para los poetas Murilo y Saudade Mendes, El Gallo y la tierra (drama histórico) con toda la amistad y cariño de José Antonio Novais Madrid 53" (El Gallo y la tierra. Madri: Ediciones Ensayos, 1952 - Centro de Estudos Murilo Mendes - Juiz de Fora)

16."Para Saudade y Murilo Mendes, mis queridos amigos, triste porque se marchan y aún no han marchado. Alfonso Pintó Barcelona, 16 de junio de 1953" (Habitado de sueño. Coleção Mensajes. Madri: Jura, 1950 - Centro de Estudos Murilos Mendes - Juiz de Fora) 
17. "Para Saudade y Murilo, con el cariño y la admiración de siempre José Antonio Novais Madri julio 55" (Miedo y hombre. Guadalajara: ColeçãoDoña Endrina, 1955 - Centro de Estudos Murilos Mendes - Juiz de Fora)

18. "A Maria da Saüdade e Murilo, amigos deste taquígrafo do rio e por procuração do próprio, of. João Cabral de Melo Neto. Rio, set. 1955" (O rio ou relação que faz o Capibaribe de sua nascente à cidade do Recife. São Paulo: Comissão do IV Centenário da cidade de São Paulo, Serviço de Comemorações Culturais, 1954 Centro de Estudos Murilo Mendes - Juiz de Fora)

1956

19."Ao Tormo, com um abraço do Cabral. Barcelona, 1956" (Duas águas: poemas reunidos. Rio de Janeiro: José Olympio, 1956 - Biblioteca particular de Enric Tormo)

20."A Maite e Santos, com um abraço afetuoso de seu amigo Cabral. Barcelona, 1956" (Duas águas: poemas reunidos. Rio de Janeiro: José Olympio, 1956 Biblioteca particular de Rafael Santos Torroella)

1957

21."A Rafael Alberti, em testemunho de admiração e simpatia o grande SALUDO de Murilo Mendes. Roma, 25 maio 1957." (Office Humain. Trad. Dominique Braga e Saudade Cortesão. Paris: Seghers, 1957 - Fundación Rafael Alberti - Puerto de Santa Maria, Cádiz)

1958

22. "A Murilo Mendes, en recuerdo de una charla en poesía y amistad de su compañero Vicente Aleixandre Madrid, 10 de octubre 1958" (La destrucción o el amor. Buenos Aires: Editorial Losada, 1954 - Centro de Estudos Murilo Mendes Juiz de Fora)

23. "Para Murilo Mendes, con la compañía poética y la amistad naciente - y esperemos que larga - de Damaso Alonso Madrid 10 de oct. 58" (Antología: crítica. Edição de Vicente Gaos. Madrid: Escelicer, 1956 - Centro de Estudos Murilo Mendes - Juiz de Fora) 
24."A Jorge Guillén, poeta ilustre, homenagem de antiga admiração e simpatia de Murilo Mendes. Nápoles, 19.12.1958" (Office Humain. Trad. Dominique Braga e Saudade Cortesão. Paris: Seghers 1957 - Biblioteca Pública de Valladolid)

\section{9}

25."A um grande poeta: A Jorge Guillén, em renovado testemunho de admiração e amizade, e para marcar o prazer de vê-lo aqui em minha casa, Murilo Mendes. Roma, 30 out. 1959" (Siciliana. Trad. A. A. Chiocchio. Caltanissetta-Roma: Sciascia, 1959 - Biblioteca Pública de Valladolid)

\section{0}

26."Ao querido Enric Tormo e gentil senhora, afetuosa lembrança do amigo e admirador Murilo Mendes. Roma, fev., 1960" (Tempo espanhol. Lisboa: Morais Editora, 1959 - Biblioteca particular de Enric Tormo)

27."A Jorge Guillén, poeta exemplar, com a afetuosa admiração e amizade de Murilo Mendes. Roma, fevereiro 1960." (Tempo espanhol. Lisboa: Morais Editora, 1959 - Biblioteca Pública de Valladolid)

28."Ao Ángel Crespo, este livro arqueológico João Cabral de Melo Madrid, 15 anos depois" ( $O$ engenheiro. Rio de Janeiro: Amigos da Poesia, 1945 - Biblioteca particular de Ángel Crespo)

29. "A Ángel Crespo, este livro em cueiros, com um abraço de seu já amigo Madrid set. 1960 João Cabral de Melo Neto" (Quaderna. Lisboa: Guimarães Editores, 1960 - Biblioteca particular de Ángel Crespo)

30."Ao Carriedo, com um abraço afetuoso do João Cabral de Melo Madri, 1960" (Quaderna. Lisboa: Guimarães Editores, 1960 - Biblioteca Pública de Valladolid)

31. "A Maite y Rafael, com um abraço amigo do João Cabral de Melo Neto Madrid, 1960" (Quaderna. Lisboa: Guimarães Editores, 1960 - Biblioteca particular de Rafael Santos Torroella)

32."A Ángel Crespo, para assinalar nosso primeiro contacto pessoal, com grande simpatia oferece Murilo Mendes Madrid, 16-IX-1960" (Tempo espanhol. Lisboa: Livraria Morais Editora, 1959 - Biblioteca particular de Ángel Crespo) 
33. "Para Ángel Crespo e María Luísa, esta pequena lembrança com o sincero afeto e as saudades do amigo e admirador Murilo Mendes Roma, janeiro 1961" (Poesias. 1925-1955. Rio de Janeiro: Livraria José Olympio Editora, 1959 Biblioteca particular de Ángel Crespo)

34. "A Ángel Crespo, con mi admiración y amistad João Cabral de Melo Neto" (Dois parlamentos. Madrid: s. ed., 1961 - Biblioteca particular de Ángel Crespo)

35."Ao Carriedo, com um abraço afetuoso do Cabral Madrid, 1961" (Dois parlamentos. Madrid: s. ed., 1961 - Biblioteca Pública de Valladolid)

36. "A Maite e Rafael, com um abraço amigo do João Madrid, 1961" (Dois parlamentos. Madrid: s. ed., 1961 - Biblioteca particular de Rafael Santos Torroella) 37. "A Jorge Guillén e Dona Irene homenagem de admiração e amizade de Murilo Mendes" "molto molto affetuosamente Giuseppe Ungaretti" (Finestra del caos. Trad. Giuseppe Ungaretti. Milão: All'Insegna del pesce d'oro, 1961 - Biblioteca pública de Valladolid)

38. "Viva España! Aos queridos Ángel Crespo e Maria Luísa Lembrança muito afetuosa de Murilo Mendes. Roma 1961." (Finestra del caos. Trad. Giuseppe Ungaretti. Milão: All'Insegna del pesce d'oro, 1961 - Biblioteca pública de Valladolid)

39. "Amigo João: He aquí mi nuevo libro, que habla de cosas de la vida, de la 'vida e morte severina' que tú lo sabes. Se te echa de menos por aquí. Un fuerte abrazo de Gabino Alejandro Carriedo Madrid 1961". Anotação de Cabral: "General Mola 289 Madri - 16" (El corazón en un puño. Santander: Publicaciones La isla de los ratones, 1961 - Biblioteca particular de Augusto Massi)

\section{2}

40. "A Jorge Guillén, homenagem cordial de seu admirador antigo João Cabral de Melo Neto 1962" (Terceira feira. Rio de Janeiro: Editora do Autor, 1961 - Biblioteca Pública de Valladolid)

41. "Ao caro Ángel Crespo, com um abraço do João Cabral de Melo Neto Madrid, 1962" (Terceira feira. Rio de Janeiro: Editora do Autor, 1961 - Biblioteca particular de Ángel Crespo) 
42. "Ao Carriedo com um abraço afetuoso e a admiração do Cabral Madrid, 1962" (Terceira feira. Rio de Janeiro: Editora do Autor, 1961 - Biblioteca Pública de Valladolid)

43. "Aos queridos amigos Maite e Rafael, saudades do João. Sevilla, 1962" (Terceira feira. Rio de Janeiro: Editora do Autor, 1961 - Biblioteca particular de Rafael Santos Torroella)

44. "A Jorge Guillén e Dona Irene, contente por encontrá-los em terra portuguesa, com todo o afeto e admiração de Murilo Mendes. Lisboa, 29. 8. 1962." (Poemas de Murilo Mendes. Trad. Dámaso Alonso. Separata da Revista de Cultura Brasileña. a. 1, n. 1, Madri, 1962 - Biblioteca Pública de Valladolid)

45. "A Jorge Guillén, poeta exemplar, amigo, querido e admirado; e à gentilíssima senhora Irene Guillén Homenagem afetuosa de Murilo Mendes. Roma, 27 novembro 1962" (Murilo Mendes. Organização de Ruggero Jacobbi; tradução de Anton Ángelo Chiocchio, Ruggero Jacobbi, Luciana Stegagno Picchio e Giuseppe Ungaretti. Milão: Nuova Accademia Editrice, 1961 - Biblioteca Pública de Valladolid) 46. "Aos queridos Ángel Crespo e Maria Luisa lembrança afetuosa de Murilo Mendes Roma 1962" (Murilo Mendes. Organização de Ruggero Jacobbi; tradução de Anton Ángelo Chiocchio, Ruggero Jacobbi, Luciana Stegagno Picchio e Giuseppe Ungaretti. Milão: Nuova Accademia Editrice, 1961 - Biblioteca particular de Ángel Crespo)

47. "Aos queridos Dámaso Alonso e Dona Eulalia, figuras da Espanha essencial, homenagem afetuosa do amigo e admirador fiel MM. Roma 1962" (Finestra del caos. Trad. Giuseppe Ungaretti. Milão: All'Insegna del Pesce D’Oro, 1961 - Real Academia Española - Madri)

\section{3}

48. "Ao caro Ángel Crespo, com abraço afetuoso do João Cabral de Melo Sevilha, 1963" (Poemas escolhidos. Lisboa: Portugália, 1963 - Biblioteca particular de Ángel Crespo)

49. "Ao Carriedo, com um abraço do João Cabral de Melo Sevilha, 1963" (Poemas escolhidos. Lisboa: Portugália, 1963 - Biblioteca Pública de Valladolid)

50. "Aos caros Maite e Rafael, seu amigo João Cabral de Melo Sevilha, 1963" (Poemas escolhidos. Lisboa: Portugália, 1963 - Biblioteca particular de Rafael Santos Torroella) 
51. "A Rafael Alberti, grande de Espanha, homenagem de Murilo Mendes. Roma, Natal 1963." (Tempo espanhol. Lisboa: Morais Editora, 1959 - Fundación Rafael Alberti - Puerto de Santa María, Cadiz)

52. "A Rafael Alberti e Maria Teresa Leon, com os melhores votos de feliz estadia na Itália, seu amigo e admirador Murilo Mendes. Roma, dezembro 1963." (Murilo Mendes. Organização de Ruggero Jacobbi; tradução de Anton Ángelo Chiocchio, Ruggero Jacobbi, Luciana Stegagno Picchio e Giuseppe Ungaretti. Milão: Nuova Accademia Editrice, 1961 - Fundación Rafael Alberti - Puerto de Santa María, Cadiz)

\section{4}

53. "A Jorge Guillén $=$ Grande de España $=$ com todo 0 afeto e admiração do seu Murilo Mendes. Roma, 31.10.64." (Poemas sobre España de João Cabral de Melo Neto. Trad. e nota crítica de Ángel Crespo e Pilar Gomez Bedate. Separata de Cuadernos Hispanoamericanos. n. 177, Madri, set. 1964 - Biblioteca Pública de Valladolid)

54. "A João Cabral de Melo, este libro, en parte dedicado a él (en la mejor parte) ) $^{398}$ con un abrazo de Ángel" (Cartas desde un pozo. 1957-1963. Santander: Publicaciones La isla de los ratores, 1964 - Biblioteca particular de Augusto Massi)

\section{5}

55. "Ao querido Jorge Guillén, figura exemplar de homem e poeta; admiradíssimo; com as minhas homenagens à Senhora Dona Irene, afetuosamente oferece Murilo Mendes. Roma 1965." (Siete poemas inéditos. Trad. Dámaso Alonso e Ángel Crespo. Separata da Revista de Cultura Brasileña. n. 12, Madri, março 1965 Biblioteca Pública de Valladolid)

\section{6}

56. "Ao caríssimo Crespo, com a amizade e admiração do João Berna, 1966" ( $A$ educação pela pedra. Rio de Janeiro: Editora do Autor, 1966 - Biblioteca particular de Ángel Crespo)

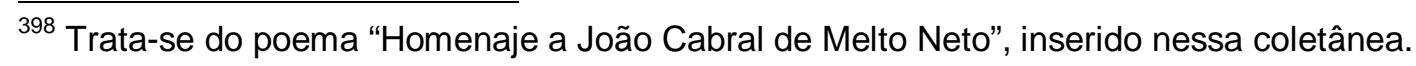


57. "Ao querido Carriedo, com a admiração do Cabral Berna, 1966" (A educação pela pedra. Rio de Janeiro: Editora do Autor, 1966 - Biblioteca Pública de Valladolid)

58. "Al maestro y amigo João Cabral de Melo, a quien tanto quiero y admiro; a quien tanto quisiera tener cerca. Con el mejor de mis abrazos Gabino Alejandro." (Los animales vivos (1951-1952). Carboneras de Guadazaón: El Toro de Barro, 1966 - Biblioteca particular de Augusto Massi)

59. "Aos queridos amigos Maite e Rafael, com a velha amizade do João Berna, 1966" (A educação pela pedra. Rio de Janeiro: Editora do Autor, 1966 - Biblioteca particular de Rafael Santos Torroella)

60. "Roma 1966. A Jorge Guillén e D. Irene, com muitas saudades \& Auguri do amigo \& admirador Murilo Mendes." (Sette poesie inedite di Murilo Mendes. Italianissima. 7 Murilogrammie. Milão: Strema per gli amici, 1965 - Biblioteca Pública de Valladolid)

61. "Para Ángel e Maria Luisa, com muito afeto, MM. Roma, 1966" (Sette poesie inedite di Murilo Mendes. Italianissima. 7 Murilogrammie. Milão: Strema per gli amici, 1965 - Biblioteca particular de Ángel de Crespo)

\section{8}

62. "Ao Carriedo, com um abraço do admirador e amigo grato Cabral 1968." (Poesias completas (1940-1965). Rio de Janeiro: Sabiá, 1968 - Biblioteca Pública de Valladolid)

63. "Para Andrea e Carriedo com admiração e afeto, Murilo Mendes. Madrid 2. 9. 1968" (Tempo espanhol. Lisboa: Morais Editora, 1959 - Biblioteca Pública de Valladolid)

1970

64. "Aos queridos Rafael \& Maria Teresa: Viva o dia 16 de dezembro 1902 que viu nascer um homem e poeta singular/ solar. Viva o amor - a liberdade - a poesia. Viva a Espanha livre. Abaixo o processo de Burgos, abaixo os netos dos inquisidores, falsos cristãos. VIVA A LIBERDADE! Roma. 16. 12. 1970. M. M." (Le metamorfosi. Trad. Ruggero Jacobbi. Milão: Lerici Editori, 1964 - Fundación Rafael Alberti - Puerto de Santa María, Cadiz). 
65. "Viva o dia 16 de janeiro 1902 (ou 1922?...) Aos muito queridos e admirados Rafael \& Maria Teresa, abraços e votos de Poesia e Liberdade em 1972 (extensivos a Aitana). Murilo. Roma, 16. 12. 1971." (Poesia libertá. Trad. Ruggero Jacobbi. Milão: Accademia Sansoni, 1971 - Fundación Rafael Alberti - Puerto de Santa María, Cadiz)

1972

66. "A Carriedo e Andrea, duas flores da minha amada Espanha, com a afetuosa amizade do Murilo Mendes. Roma 1972." (Poesia libertà. Ed. Ruggero Jaccobi. Milão: Accademia-Sansoni, 1971 - Biblioteca Pública de Valladolid)

67. "Aos queridos Gabino-Alejandro Carriedo e Andrea, lembrança afetuosa de M.M. Roma 1972." (Poliedro. Rio de Janeiro: José Olympio, 1972 - Biblioteca Pública de Valladolid)

1976

68. "Ao caro Ángel Crespo, com a velha amizade e admiração do João Cabral de Melo Neto Dakar, 1976" (Museu de tudo. Rio de Janeiro: José Olympio Editora, 1975 - Biblioteca particular de Ángel Crespo)

69. "Aos queridos Maite e Rafael, nosso de sempre, João Cabral de Melo Dakar, 1976" (Museu de tudo. Rio de Janeiro: José Olympio Editora, 1975 - Biblioteca particular de Rafael Santos Torroella)

1980

70. "A mi querido maestro y amigo João Cabral de Melo Neto, con el recuerdo permanentemente y la pena de no recibir noticias suyas. Su affemo. Gabino Alejandro Mayo 1980" (Nuevo compuesto descompuesto viejo (Poesía 19481978). Madri: Peralta, 1980 - Biblioteca particular de Augusto Massi) 


\section{Poemas e livros dedicados}

\section{A ALBERTI, Rafael}

"Jardins do Generalife" In Tempo espanhol (1959), de Murilo Mendes.

\section{A ALEIXANDRE, Vicente}

"Sevilha" In Tempo espanhol (1959), de Murilo Mendes.

\section{A ALONSO, Damaso}

"Toledo" In Tempo espanhol (1959), de Murilo Mendes.

\section{A ALONSO, Damaso e GUILLÉN, Jorge "Grandes de Espanha"} Espaço espanhol (1994), de Murilo Mendes.

\section{A ALTOLAGUIRRE, Manuel \\ "O sol de Granada" In Tempo espanhol (1959), de Murilo Mendes.}

\section{A BERGAMÍN, José}

“Ávila” In Tempo espanhol (1959), de Murilo Mendes.

\section{A Bousoño, Carlos}

"O passante de Sevilha" In Tempo espanhol (1959), de Murilo Mendes.

\section{A CARRIEDO, Gabino-Alejandro}

"Rios sem discurso" In A educação pela pedra (1966), de João Cabral de Melo Neto.

\section{A CERNUDA, Luis}

"O sol de llhescas" In Tempo espanhol (1959), de Murilo Mendes.

\section{A CRESPO, Ángel}

"Para a feira do livro" In A educação pela pedra (1966), de João Cabral de Melo Neto. 


\section{A DIEGO, Gerardo}

"Chuva em Castela" In Tempo espanhol (1959), de Murilo Mendes.

\section{A GUILLÉN, Jorge}

"Monteserrat" In Tempo espanhol (1959), de Murilo Mendes.

\section{A MELO NETO, João Cabral de}

"Oda lliure a Joan Ponç" In Sortija (1948) de Joan Brossa.

"Nadie" In Nadie. Poemas del avión (1954), de Rafael Santos Torroella.

Parábola (1959), de Murilo Mendes.

"Camí a dret fil" In Sonets de Caruixa In Poesia rasa (1970), de Joan Brossa. ${ }^{399}$

"Variaciones en torno a la recta" In Los lados del cubo (1973), de Gabino-Alejandro Carriedo.

"Vela" In Lembranças e deslembranças (1972-1980) (1988), de Gabino-Alejandro Carriedo.

\section{A MELO, João e Stella Cabral de}

"El toro" In Habitado de sueño (1950), de Alfonso Pintó.

\section{A MENDES, Murilo}

Quaderna (1960), de João Cabral de Melo Neto.

Parte Noturnos In Y otros poemas (1973), de Jorge Guillén.

"A voz dos meus avós" In Lembranças e deslembranças (1972-1980) (1988), de Gabino-Alejandro Carriedo.

\section{A OTERO, Blas de}

"Pueblo" In Tempo espanhol (1959), de Murilo Mendes.

\section{A PINTÓ, Alfonso}

"Crianças de Tarragona" In Tempo espanhol (1959), de Murilo Mendes.

\footnotetext{
${ }^{399}$ Esse poema não consta da primeira edição de 1949, impressa por Cabral.
} 


\section{A TORMO, Enric e Maria}

"Barcelona" In Tempo espanhol (1959), de Murilo Mendes.

\section{A TORROELLA, Rafael Santos}

"A Palo seco" In Quaderna (1960), de João Cabral de Melo Neto.

\section{A TORROELLA, Rafael e Maite Santos}

"Manola" In Tempo espanhol (1959), de Murilo Mendes.

\section{A NOVAES, José Antonio}

"Madrid" In Tempo espanhol (1959), de Murilo Mendes. 


\section{Traduções da obra de João Cabral de Melo Neto na Espanha}

1.Rafael Santos Torroella: Fragmentos VII e VIII de "Psicologia da composição"; "El ingeniero"; Dois primeiros fragmentos de "El perro sin plumas" (Antología de la poesía brasileña. Edição de Renato de Mendonça. Madri: Ediciones Cultura Hispánica, 1952)

\section{2.Ángel Crespo:}

2.1. Seis poemas de Serial ("El sí contra el sí", com fragmentos de "Miró", "Mondrian", "Juan Gris" e "Juan Dubuffet", e "El huevo de gallina") (Revista de Cultura Brasileña. n. 1, Madri, jun. 1962, p. 42-51)

2.2. "Poema(s) de la cabra" (Más barato. Negro de vida. Solo corteza), "Estudios para una bailadora andaluza" e "A palo seco", de Quaderna; "Lluvias", de Serial (Antología de la poesía brasileña. Desde el Romanticismo a la Generación del cuarenta y cinco. Barcelona: Seix Barral, 1973)

2.3. A la medida de la mano. Salamanca: Universidad de Salamanca, 1994

\section{3.Ángel Crespo e Pilar Gomez Bedate:}

3.1. "Pernambuco en Málaga", "Lluvias" e "Una sevillana en España", de Serial; "Estudios para una bailadora andaluza", "A palo seco" e "Sevilla", de Quaderna; "Medinaceli", "Imagens en Castilla" e "Diálogo", de Paisagens com figuras (Poemas sobre España de João Cabral de Melo Neto. Separata de Cuadernos Hispanoamericanos. Revista mensual de cultura hispánica. a. 59, n. 177, Madri, set. 1964, p. 333-351);

3.2. "El toro de Lidia", "El futbol brasileño evocado desde Europa", "El museo de todo" e "Doble díptico", de Museu de tudo (Revista de Cultura Brasileña. n. 41, Madri, jun. 1976, p. 30).

\section{4.Ángel Crespo e Gabino-Alejandro Carriedo:}

4.1. Vida y muerte Severina, auto de navidad pernambucana. (Primer acto. n. 75, Madri, jun. 1966, p. 52-59)

4.2. "Poema(s) de la cabra" (Más barato. Negro de vida. Solo corteza), "A palo seco" de Quaderna; "El huevo de gallina", de Serial (Ocho poetas brasileños. Carbonera de Guadazón (Cuenca): El Toro del Barro, 1966) 


\section{Gabino-Alejandro Carriedo:}

5.1. "Tejiendo la mañana", de A educação pela pedra (Breve relación casi periódica de poesía distinta contemporánea y no homologada. n. 1, Madri, 1968, p. 8)

5.2. "Encuentro con un poeta", de Paisagens com figuras. (Homenaje a Miguel Hernández. Edição de Maria de Gracia Ifach e Manuel Garcia Garcia. Barcelona, Plaza \& Janes, 1975)

5.3.Dos parlamentos. (Poesia, revista ilustrada de información poética. n. 9, Madri, 1980, p. 67-79)

6.Pablo del Barco: La educación por la piedra. Madri, Visor, 1982.

7. Cintia Massip Bonet: L'Enginyer. Psicologia de la composición amb la faula d’Anfió i Antioda. Barcelona: Edicions 62, 1994. 


\section{Traduções da obra de Murilo Mendes na Espanha}

1. Alfonso Pintó: "Ventanas del caos", de Poesia liberdade (Antología de poetas brasileños de ahora. Barcelona: El Libro Inconsútil, s.d.)

2. Rafael Santos Torroella: "Los dos lados", de Poemas; "Anti-elegía", "Mozart" e "Juego", de Os quatro elementos; "Ana Luisa", "Poema abierto", "Pariente próximo", "Poema barroco" e "Pertubación", de Mundo enigma; "Deseo", "Tiempos sombríos", "Murilo niño" e "Memoria", de Poesia liberdade. (Antología de la poesía brasileña. Edição de Renato de Mendonça. Madri: Ediciones Cultura Hispánica, 1952)

3. Dámaso Alonso: "Jandira" de O visionário; "El fuego" de Os quatro elementos; "Poema espiritual", "Las cuatro de la tarde" e "El amor y el cosmos", de A poesia em pânico; "Poema barroco", de Mundo enigma; "Abstracción", de Poesia liberdade; "El rito humano" e "El muerto", de Sonetos brancos; "Allá lejos", de Parábola; "Faena de Góngora" e "Córdoba", de Tempo espanhol (Revista de Cultura Brasileña. a. 1, Madri, jun. 1962, p. 10-18)

4. Dámaso Alonso e Ángel Crespo: "Murilograma à filha de Miguel Torga", "Murilograma a Guido Cavalcanti", "Murilograma a Carla Accardi", "Grafito para Capogrossi", "Natal 1961", "Morte de Borromini" e "Claudio Monteverdi" (Revista de cultura brasileña. n. 12, Madri, março 1965, p 8-21)

5. Ángel Crespo: "El niño sin pasado", "Mapa" e "Canto del novio", de Poemas; "Biografía de la melena" e "Novíssimo Prometeu", de O visionário; "Estrelas" de Os quatro elementos; "Caballos", "El pastor pianista" e "Ante un cadáver", de As metamorfoses; "Ideas rosas", de "Meditação de Agrigento", de Siciliana; "San Juan de la Cruz", de Tempo espanhol. (Antología de la poesía brasileña. Desde el Romanticismo a la Generación del cuarenta y cinco. Barcelona: Seix Barral, 1973) 


\section{Artistas plásticos espanhóis no acervo de Murilo Mendes ${ }^{400}$}

\section{ALBERTI, Rafael:}

Los ojos Picasso (II), 1966 (Gravura em metal/ papel 9/ 50; 64,1 x 49, 9 cm; ass./dat.)

Dedicatória: "Para Saudade y Murilo Mendes, grandes amigos R. Alberti - 66". No retrato-relâmpago sobre Alberti, Murilo comenta a vertente plástica: “(...) Alberti começou a vida como pintor. Escreveu mesmo um livro, A la Pintura, que gira todo em volta dessa grande arte. Ultimamente dedicou-se em Roma à gravura, técnica que tem estudado com fervor e minúcia, manifestando ofício seguro seguro e dom de invenção na série de gravuras de chumbo 'Los ojos de Picasso'. A interpretação da poesia e da pintura no campo da obra albertiana é um fato consciente, voluntário, pois há muito ele programou sua ação: ...'pintar la Poesía/ com el pincel de la Pintura'. (PCP, 1224)

\section{MIRÓ, Joan:}

Nebuleuse, 195 (Litografia/ papel 42/100; 49,6 x 65, $1 \mathrm{~cm}$; ass./dat.)

S/ título, 1967 (Litografia/ papel;11,3 x 16,5cm; ass./dat.). Dedicatória: “Joan Miró Vous Souhaite une Bonne anné. 1967"

S/ título (Litografia, 42/100; 49,7 x 65 cm; ass./ n. dat.)

\section{PICASSO, Pablo:}

S/ título, 1934 (Água-forte/ papel; 44 × 33,5 cm; ass./ dat.)

S/ título, 1947 (Litografia/ papel 11/50; 65 × 50 cm; ass./ dat.)

${ }^{400}$ Centro de Estudos Murilo Mendes - uiz de Fora. 
Imagens 